\title{
PRELIMINARY GEOLOGIC,
}

PETROLOGIC, AND PALEONTOLOGIC RESULTS OF THE STUDY OF NANUSHUK GROUP ROCKS, NORTH SLOPE, ALASKA

GEOLOGICAL SURVEY CIRCULAR 794 
Cover:

Corwin Bluff along the Chukchi Sea.

Note helicopter for scale. 
PRELIMINARY GEOLOGIC,

PETROLOGIC, AND PALEONTOLOGIC

RESULTS OF THE STUDY

OF NANUSHUK GROUP ROCKS,

NORTH SLOPE, ALASKA

BY THOMAS S. AHLBRANDT, EDITOR

\begin{tabular}{llll}
\hline GEOLOGICAL SURVEY CIRCULAR & 794
\end{tabular} 


\section{United States Department of the Interior}

\section{CECIL D. ANDRUS, Secretary}

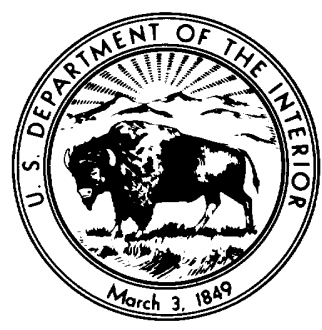

\section{Geological Survey}

H. William Menard, Director 


\section{CONTENTS}

Page

Introduction to geologic studies of the Nanushuk Group, North Slope, Alaska, by T. S. Ahlbrandt-

Nanushuk Group deposition and the Late Mesozoic structural evolution of the central and western Brooks Range and Arctic Slope, by C. G. Mull-_-

Depositional framework and reservoir quality studies of selected Nanushuk Group outcrops, North Slope, Alaska, by T. S. Ahlbrandt, A. C. Huffman, J. E. Fox, and Ira Pasternack--

Subsurface studies of the Nanushuk Group, North Slope, Alaska, by K. J. Bird and J. Andrews-A summary of reservoir characteristics of the Nanushuk Group, Umiat test we11 11 , National Petroleum Reserve in Alaska, by J. E. Fox-

Hydrocarbon source potential of the Nanushuk Group and the Torok Formation, a preliminary report, by L. B. Magoon and G. E. Claypool-

Textural and mineralogical study of some surface and subsurface sandstones from the Nanushuk Group, western North Slope, Alaska, by S. Bartsch-Winkler----

Stratigraphy and petrography of a measured section on the south limb of Barabara Syncline, North Slope, Alaska, by A. C. Huffman-

Some Cretaceous plant megafossils and microfossils from the Nanushuk Group, Northern Alaska, a preliminary report, by R. A. Scott and C. J. Smiley-------

Dinoflagellate and Acritarch assemblages from the Nanushuk Group (Albian-Ceonomanian) and the Torok Formation (Albian), Umiat test well 11, National Petroleum Reserve in Alaska,

northern Alaska, by F. E. May-
Dinoflagellate and acritarch assemblages from the Grandstand Formation (Middle to Upper Albian) of the Nanushuk Group, Simpson Core Test 25, National Petroleum Reserve in Alaska, northern Alaska, by F. E. May and J. A. Stein-_-

Cretaceous foraminifers from the North Slope of Alaska, by W. V. Sliter--References cited

\section{ILLUSTRATIONS}

Figure 1. General North Slope index map-_-

2. Generalized nomenclature and stratigraphic relationships of Lower Cretaceous sediments, western and central North Slope-

3. Index map of structures and physiographic subdivisions of the North Slope--------

4. Schematic thrust sheet sequence along north flank of the Brooks Range---------

5. Stratigraphic nomenclature of Nanushuk Group-

6. Schematic cross-section of Nanushuk rocks, western North Slope--

7. Selected measured sections of Nanushuk rocks- Sedimentary features of Nanushuk rocks in outcrop-

9. Sandstone percent histograms of selected Nanushuk outcrop sections-

10. Index map of selected Nanushuk Group data-

11. Seismic section through Drew Point 1 well-_-

12. Diagrammatic stratigraphic diagram relating rocks of NPRA and Prudhoe Bay--------

13. Diagrammatic Cretaceous time-stratigraphic chart for northern NPRA----------

14. Cretaceous section in Drew Point 1 well-

15. Directional (paleotransport) data for sediments of the Torok Formation and Nanushuk Group--

16. Log response and 1ithofacies in three NPRA wells-

17. Isopach map including both Torok Formation and Nanushuk Group-- 
18. Nanushuk Group isopach map-

19. Torok Formation isopach map-_-

20. Index map of Umiat Anticline region-_-

21. Stratigraphic column of Umiat test wel1 11

22. Deltaic interpretation of Lower Cretaceous rocks in eastern NPRA--------------

23. Description of core 60, Grandstand Formation, Umiat test well 11--_-

24. Description of cores 56-58, Grandstand Formation, Umiat test well 11-_-_-

25. Description of cores 52-53, Grandstand Formation, Umiat test well 11-_-

26. Description of core 49, Killik Tongue of Chandler Formation, Umiat test we11 11---

27. Description of cores 35-38, Ninuluk Formation, Umiat test wel1 11-_- - - - - - -

28. Porosity and permeability relationships of Cretaceous rocks, Umiat test well 11---

29. Organic geochemistry data for Nanushuk Group and Torok Formation from the

Kukpowruk type section and Kaolak No. 1 well--

30. Organic geochemistry data for Cretaceous rock units in Topagoruk No. 1 well and Umiat test well $11-$

31. Index map of outcrop and subsurface petrography samples------

32. Textural properties of Nanushuk sandstones as determined petrographically---------

33. Ternary plots of Nanushuk sandstone petrographic data-- -

34. Photographs of pore-linings in sandstones of the Nanushuk Group---

35. Scanning electron microscope photographs of pore-linings in sandstones of the Nanushuk Group-

36. Index map showing sample locations along the south limb of Barabara Syncline------- 77

37. Ternary diagrams of petrographic data, Barabara Syncline, using Dickson's (1970) methods-

38. Ternary diagrams of petrographic data, Barabara Syncline, using Folk's (1968) methods-

39. Histograms of reservoir quality parameters Barabara Syncline--_-

40. Graphic presentation of petrographic data, Barabara Syncline--_-

41. Stratigraphic sequences of Mississippian to Lower Cretaceous rocks, western North Slope--

42. Index map showing plant macrofossil and microfossil localities, Nanushuk Group, northern Alaska

43. Stratigraphic ranges of selected plant megafossils, northern Alaska--_-- - - - -

44. Stratigraphic occurrence and distribution of Nilssoniopteris palymorpha, northern Alaska--

45. Index map showing location of Simpson core test 25-

46. Columnar section of Grandstand Formation, Simpson core test 25-_-

47. Index map showing sample and well localities studied for foraminiferal assemblages- 148

48. Distribution of foraminifers in Albian to Cenomanian interval of Umiat test well $11-$

P1ate 1-7. Selected plant fossils of the Nanushuk Group--

8-12. Selected dinoflagellates and acritarchs from Umiat test wel1 11- - - - - -

13-17. Selected dinoflagellates and acritarchs from Simpson core test 25-------------136-145

18. Selected foraminifers from Torok Formation and Nanushuk Group of Umiat test well $11-----154$

19. Selected foraminifers from Torok Formation and Nanushuk Group surface sections---- 156

TABLES

Table 1. Synthesis of resource related data gathered in 1977 outcrop studies-------------

2. Selected Nanushuk outcrop and subsurface data- 
3. Organic geochemical data from outcrop and core material of Cretaceous rock units,

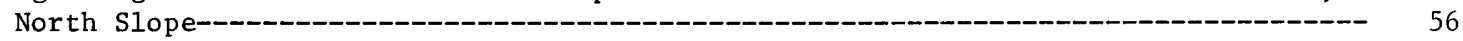

4. Clast compositions in Nanushuk Group petrographic samples

5. Composition of samples from south limb of Barabara Syncline--

6. Textural data of samples from south limb of Barabara Syncline-------

7. Uranium and thorium content of samples from south limb of Barabara Syncline-------- 83

8. Ranges of dinoflagellates and acritarchs from the Nanushuk Group and Torok Formation, Umiat test wel1 $11-$

9. Ranges of dinoflagellates and acritarchs from the Grandstand Formation, Simpson core test 25--------

10. Foraminifer-bearing samples from the Kukpowruk type section-_-_-

11. Foraminifer-bearing samples from the Seabee Formation in the Ninuluk Bluff section- 153

12. Foraminifer-bearing samples from the Tuktu Bluff section--- 


\section{INTRODUCTION TO GEOLOGIC STUDIES OF THE NANUSHUK GROUP, NORTH SLOPE, ALASKA}

By Thomas S. Ahlbrandt

\section{ABSTRACT}

Sediments of the Nanushuk Group of early Albian to Cenomanian age are a major hydrocarbon play within the National Petroleum Reserve in Alaska. In a series of 12 chapters by 15 authors, basic geologic, geochemical, petrologic, and paleontologic data are summarized. Together, they permit a better evaluation of the hydrocarbon potential of the Nanushuk Group.

Lower Cretaceous sedimentation on the North Slope reflects the uplift of the Brooks Range and attendant deposition in a marine basin along the north flank of this range. Sediments that fill this marine basin demonstrate a change from deepwater deposits. The sediments grade upward into the Torok Formation (predominantly shale) that is subjacent to the shallow-marine, deltaic, and interdeltaic sediments of the Nanushuk Group. The generally northeast progradation of Nanushuk sediments away from the Brooks Range is indicated by paleotransport data from outcrops as well as by seismic and dipmeter data in wells on the North Slope. At least two river-dominated deltas are hypothesized for onshore Nanushuk rocks: a western Corwin delta and, in the central North Slope, the Umiat delta. The composition of Nanushuk sandstones differs in the western and central North Slope regions, probably reflecting different 1ithologies exposed during Early Cretaceous time in the sediment source terrains to the south. Nanushuk sandstones are all generally classified petrographically as 1itharenites, and reservoir-quality problems within these sandstones are related chiefly to abundant clay matrix, carbonate cement, or ductile (labile) grains. Sedimentary rock fragments are common in the Nanushuk sandstones in the western North Slope, but in the central North Slope, Nanushuk sandstones commonly contain metamorphic rock fragments and have a higher quartz sand content than western sandstones. Preliminary data indicate that the composition of Nanushuk sandstones, particularly in highenergy environments, is relatively better in the central area than in equivalents to the west; however, reservoir-quality problems in sandstone of both areas are numerous and of concern.
Potential hydrocarbon source beds within the Nanushuk in the central North Slope are relatively less thermally mature than those in the western area, which are relatively more mature or "gas prone." The relative immaturity of potential Nanushuk source beds in the central North Slope means, for example, that the oil produced from Nanushuk sandstones in the Umiat oil field may have migrated, perhaps along faults, from pre-Nanushuk sources. Alternatively, the Umiat oil may also have come from shales of the Torok Formation, equivalent in age to the Nanushuk, or even from overlying shales of the Seabee Formation, both of which are more deeply buried northeast of Umiat. Correlation of rock units of the Nanushuk requires the integration of spore, pollen, and plant megafossil zonations in nonmarine intervals and of dinoflagellace, foraminiferal, and limited faunal zonations in marine intervals. These zonations are now established for several reference sections in either the western or central North Slope. Each zonation is being extended to other locations and is being integrated with other fossil zonations. However, the problem of revision of the complex stratigraphic nomenclature of the Nanushuk Group is avoided here because, in my opinion, data are too preliminary and too widely scattered to permit such revision and correlation at this time. Thus, the general stratigraphic terms of Torok Formation and Nanushuk Group with appropriate modifiers (commonly related to depositional environment) or previously named units are used here.

Chapters of this Circular summarize approximately the first half of the present two-year Nanushuk study.. The authors have used all data available to them, either previously published or newly generated. Although the word "preliminary" is part of the title of this Circular, the contributions represent the latest analyses. and synthesis of data available, and the preliminary label may be an unjust assessment of some of the chapters.

\section{INTRODUCTION}

Sediments of the Nanushuk Group of Cretaceous age (early Albian to Cenomanian) constitute a major hydrocarbon play within the NPRA 


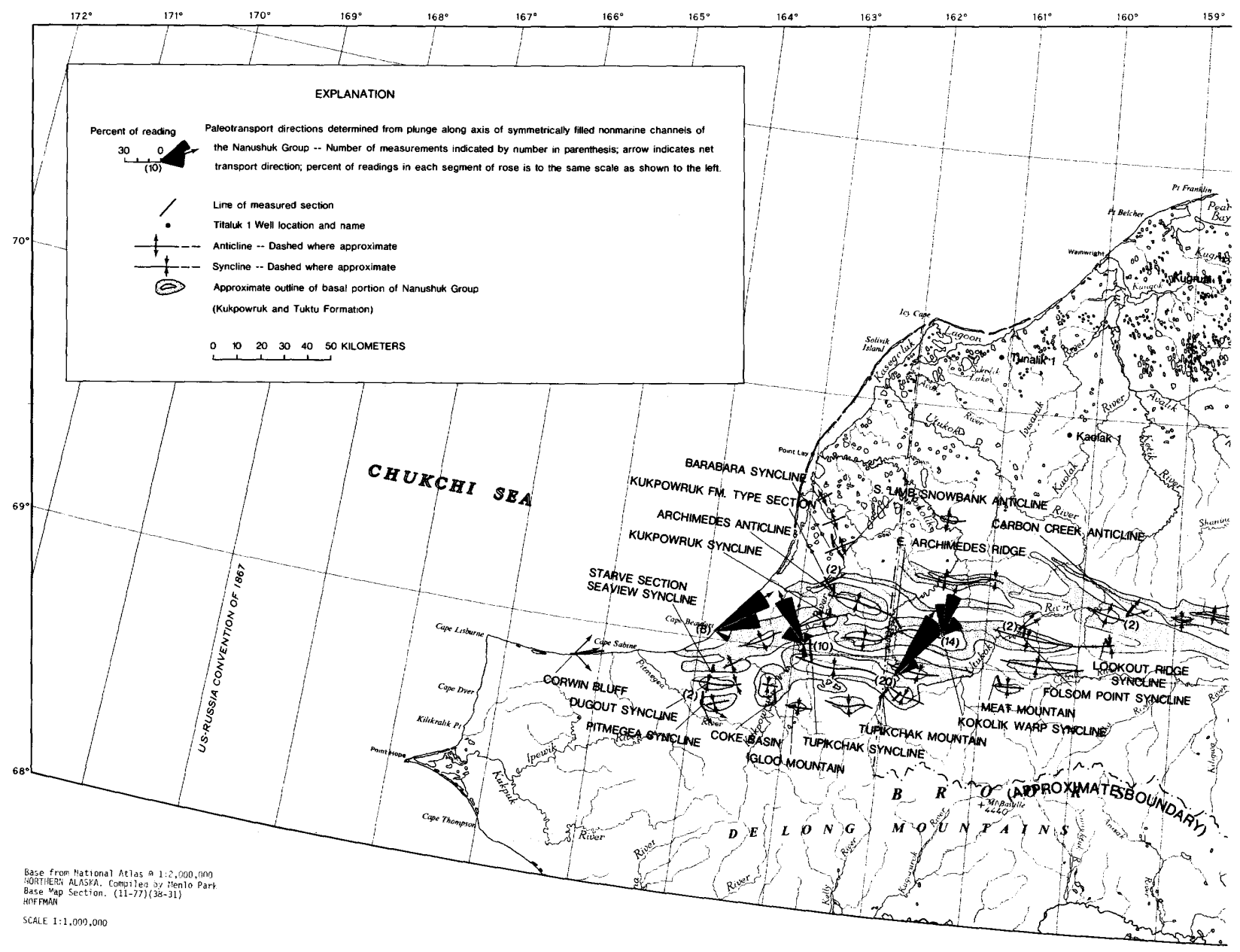

Figure 1.--Index map of sections of Nanushuk Group rocks measured in 1977

(National Petroleum Reserve in Alaska) (Carter and others, 1977). Currently, the most significant known oil field within NPRA is in Nanushuk Group rocks at Umiat Anticline in the southeastern part of NPRA (estimated reserves of 122 million barrels; Espach, 1951). The goal of this project is to evaluate the resource (principally hydrocarbon) potential of Nanushuk Group rocks. The chapters in this Circular summarize recent preliminary results of studies designed to provide a geologic framework to adequately assess the hydrocarbon potential of the Nanushuk Group.

The Nanushuk Group was studied by a number of U.S. Geological Survey personnel coincident with exploration of Naval Petroleum Reserve No. 4 (NPR-4) in the 1940's and 1950's, and many basic data were published by these geologists. The renewed exploration of NPRA in the mid$1970^{\prime}$ 's necessitates an updated geologic study of the Nanushuk. New concepts such as the reservoir-quality problems associated with compositionally complex (quartz-poor) sandstones, new biostratigraphic techniques (zona- tion with dinoflagellates), recently completed organic geochemical analyses of potential source beds, new seismic and well data, as well as the use of deltaic sedimentary models, complement and improve our understanding of the Nanushuk.

The present study has a short duration (2 years) and is in cooperation with the current NPRA exploration program. This publication accommodates the need to disseminate information as rapidly as possible to assist exploration needs as well as provide basic data for subsequent work. The articles are arranged first regionally and then topically. A common denominator for the topical articles is the discussion of at least one reference section located either in the western North Slope region or in the central North Slope region (eastern NPRA). The sections in the western region include the Kaolak 1 well and outcrop sections along the Kukpowruk River--the type section of the Kukpowruk Formation; the Barabara Syncline section; and, for nonmarine fossil zonations, the Corwin Bluff section, the type section of 


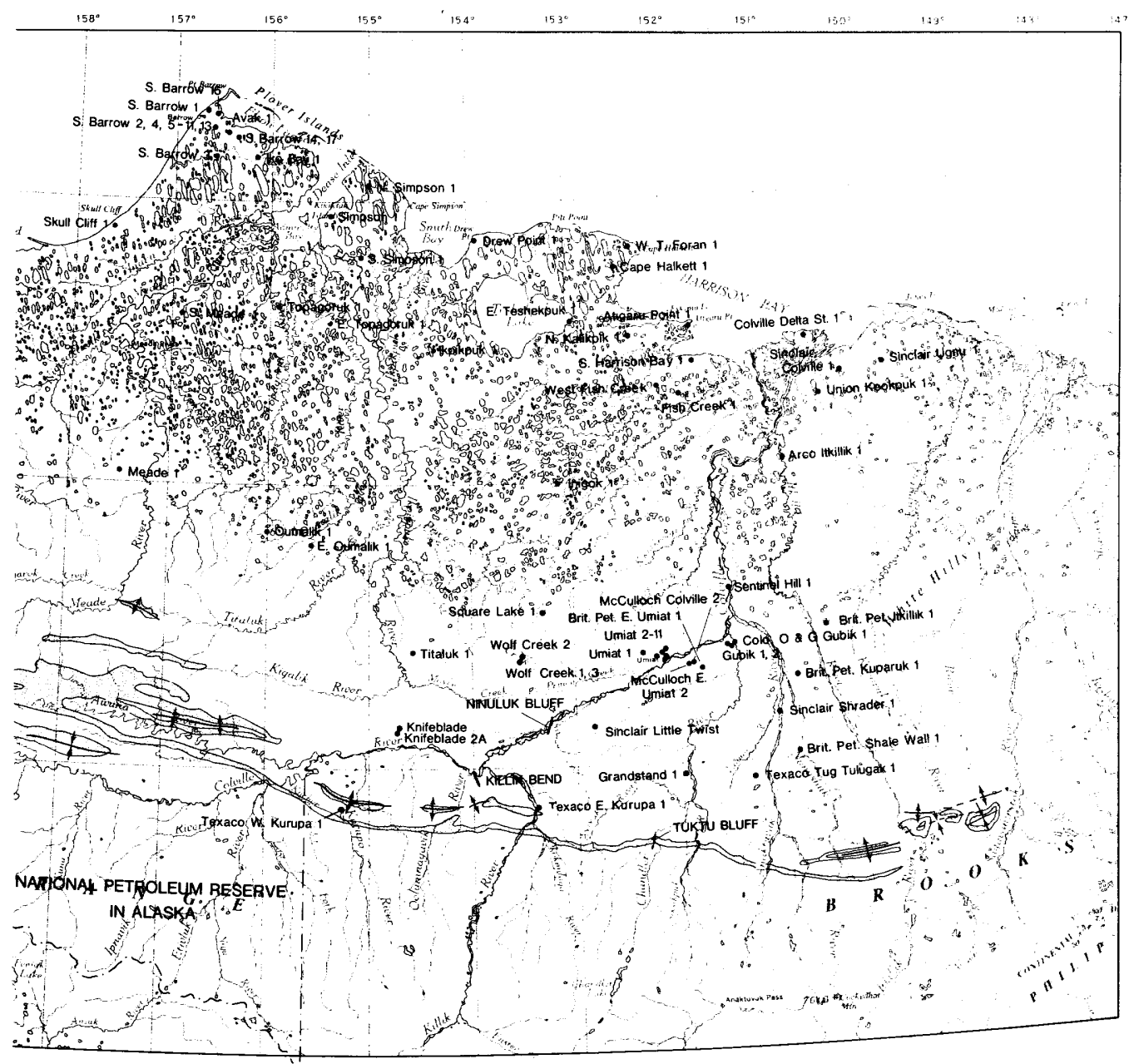

and of well locations in the western and central North Slope areas of Alaska.

the Corwin Formation as described by Chapman and Sable, 1960 (fig. 1). The reference section in the central North Slope region is Umiat test wel1 11 .

Umiat test well 11 is important for many reasons: (1) it contains the most continuously cored, unfaulted section of subsurface Nanushuk Group rocks in the eastern NPRA; (2) it contains the type section of the Seabee Formation (Colville Group), which overlies the Nanushuk Group (Collins, 1958a); (3) it has received the most detailed sedimentologic, petrographic, and reservoir analysis of any well that penetrates the Nanushuk in the NPRA (Fox and others, 1979); and (4) although it is a dry hole, it is on Umiat Anticline, which contains the Umiat oil field and provides data that demonstrate the parameters affecting reservoir quality of Nanushuk sandstones.

The establishment of reference sections, particularly Umiat test well 11, from which subsequent extrapolations will be made is the focus of several of the chapters. Although this report is preliminary, many of the zona- tions, petrography, and so forth have been applied successfully to other wells or sections. This paper summarizes the first year's work on the project and includes data gathered in the 1977 field season. The locations of the measured stratigraphic sections, paleotransport data gathered in nonmarine channels of the Nanushuk, and the outline of marine intervals in outcrops of the Nanushuk are shown in figure 1. The outcrop and well localities referred to in subsequent chapters are shown on this figure to avoid repetition in each chapter.

Briefly, the sequence and significance of the contributions are as follows: The first chapter, by C. G. MuIl, discusses the physiography of the North Slope and the structural and stratigraphic framework relevant to the Nanushuk; it is fundamental to the understanding of subsequent chapters. Mull originally proposed the present study of the Nanushuk and has generously assisted all members of this project since its inception.

The following chapter by Ahlbrandt, Huffman, Fox, and Pasternack summarizes the 
1977 outcrop studies, most of which were made in the western North Slope. They use deltaic models to provide a depositional framework within which potential Nanushuk reservoirs may be evaluated. They suggest that Nanushuk sediments, as observed in outcrop, may be related to at least two river-dominated deltas: the Corwin delta in the western North Slope and the Umiat delta in the central North Slope. At this point, the reservoir quality of Nanushuk sandstones of the Umiat delta seems more favorable than that of Corwin delta sandstones. The integration of surface (outcrop) and subsurface data is a desired goal of this project. Al1 outcrop data collected in 1977 , some $14,600 \mathrm{~m}$ of section, were encoded and placed in a computer file at Petroleum Information in Denver, Colo. Computer-drawn displays of these measured sections are treated as if they are well locations and are comparable with the Well History Control System (WHCS) of Petroleum Information that is being used to compile NPRA subsurface data. Direct comparison of well logs and measured sections of any desired parameter allows integration of surface and subsurface data.

The chapter by Bird and Andrews includes new seismic and well data and integrates such data with outcrop studies (for example, paleotransport directions, isopach maps) when possible. The northeasterly progradation of Nanushuk sediments and their relationship to the subjacent Torok Formation sediments are easily seen on seismic records and correspond to similar observations of these sediments in outcrop.

The chapter by Fox, summarizing the study by Fox and others (1979) of Umiat test well 11, sets the depositional and petrographic framework for subsequent chapters and establishes this well as the eastern NPRA subsurface reference section for dinoflagellates and foraminifera. This section will be used for other kinds of comparisons as data become available.

In Magoon and Claypool's chapter, the observation that the oil in the Umiat oil field has most probably migrated from "hotter, deeper strata" may demonstrate the importance of fault-bounded structures such as Umiat Anticline in providing both hydrocarbon charge and closure to reservoir sandstones of the Nanushuk in the central North Slope. Their observation of more thermally mature source beds. within the Nanushuk in the western North Slope relative to the central North Slope will certainly be of interest for both oil and gas exploration of the Nanushuk.

Diagenesis of compositionally immature sandstones is of serious concern regarding the reservoir quality of Nanushuk reservoirs. The chapter by Bartsch-Winkler provides a regional petrographic evalution of both surface and subsurface Nanushuk sandstones. The petrographic differences between Nanushuk sandstones in the western and central areas of the North Slope may also relate to different source areas for the two proposed Nanushuk deltas. The following chapter by Huffman discusses the petrography of Nanushuk sandstones in a western reference section (the Barabara Syncline section) in detail. It can be compared to the detailed petrographic discussion of Nanushuk sandstones of the eastern NPRA reference section (Umiat 11) discussed by Lambert in Fox and others (1979).

Correlation of rock units within the Nanushuk across the North Slope is a problem due in part to the paucity of macrofaunal and planktonic foraminiferal assemblages in the Nanushuk. Thus, a threefold biostratigraphic approach is used. Zonation by spores, pollen, and plant megafossils is applied to nonmarine intervals (chapter by Scott and Smiley), whereas zonation by dinoflagellates (chapters by May, and May and Stein) and (or) foraminifera (chapter by Sliter) becomes more useful in marine intervals. Key fossils are documented in plates found in each of these three chapters. At this preliminary stage, the zonations appear to integrate we11 and provide a means of correlating nonmarine and marine sediments within the time-transgressive deltaic and interdeltaic deposits of the Nanushuk with prodelta and basinal strata of the subjacent Torok Formation. 
NANUSHUK GROUP DEPOSITION AND THE LATE

MESOZOIC STRUCTURAL EVOLUTION OF THE CENTRAL

AND WESTERN BROOKS RANGE AND ARCTIC SLOPE

By C. G. $\mathrm{Mu} 11$

\section{INTRODUCTION}

Sediments of the Nanushuk Group of Albian to Cenomanian Age are widespread on the Arctic Slope of northern Alaska, where they crop out extensively in the northern foothills of the Brooks Range and extend northward under the Arctic Coastal Plain. The sediments consist of a molassoid wedge that was shed from the north flank of the Brooks Range orogenic belt and represent the culmination of a sequence of Early Cretaceous tectonic events. These rocks are of particular interest as a potential hydrocarbon reservoir within the National Petroleum Reserve in Alaska (NPRA). The tectonic history and depositional setting in which the Nanushuk Group was deposited and deformed are briefly described in this chapter of the Circular, along with some aspects of the history which may influence the hydrocarbon potential of the Nanushuk sediments. Greater detail on the Nanushuk is presented in other chapters.

The generalized nomenclature and stratigraphic relationships of the Lower Cretaceous and Cenomanian sediments of the western and central Arctic Slope, including NPRA, are summarized on figure 2. Nanushuk nomenclature is outlined by Detterman (1956). Generalized geologic maps of the Arctic Slope and Brooks Range have been compiled by Lathram (1965), Beikman (1976, 1978), and Grybeck and others (1977). These maps provide the best published overview of the geology of northern Alaska.

In the area of the western and central Arctic Slope and Brooks Range foothills, the area of the studies reported in this Circular, the Cretaceous sediments in general seem to grade from a thick basal flysch sequence upward to over $3,000 \mathrm{~m}$ consisting dominantly of shale, and then into a section of shallow marine to deltaic sediments, the Nanushuk Group of Albian to Cenomanian Age. The sequence thus seems to record the progressive filling of the Colville basin, a deep asymmetric foredeep north of the Brooks Range orogenic belt, and may be considered a typical gradational flysch to molasse sequence, with the Nanushuk Group representing post-orogenic molasse deposits.

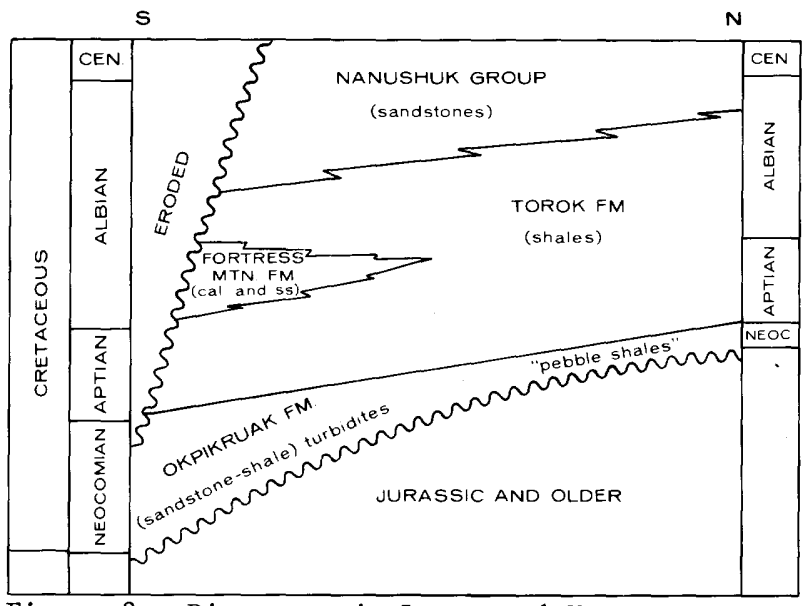

Figure 2.--Diagrammatic Lower and Upper Cretaceous stratigraphic relationships across the Colville basin, from the Brooks Range to the Beaufort Sea.

\section{PHYSIOGRAPHIC SETTING OF THE NANUSHUK OUTCROP BELT}

The Northern Foothills Section of the Arctic Foothills Province and the Nanushuk outcrop belt extend unbroken from the sea cliffs of the Cape Corwin area on the west for about $650 \mathrm{~km}$ eastward to the Sagavanirktok River area of the eastern Arctic Slope (fig. $3)$. Across this distance the province is characterized by generally east-west-trending ridges and rolling upland terrain to an elevation of about $960 \mathrm{~m}$. The ridges and uplands are broken by numerous generally northwardflowing streams and rivers, many of which rise in the Brooks Range. On the west, four small rivers--the Pitmegea, Kukpowruk, Kokolik, and Utukok--cross the outcrop belt of the Nanushuk Group and flow into the Chukchi Sea. These streams are relatively small, but in places they and their tributaries are incised over 500 $\mathrm{m}$ into the Nanushuk terrain. As a consequence of this incision, the Nanushuk exposures on the western Arctic Slope are generally better and are found over a wider north-south extent than 


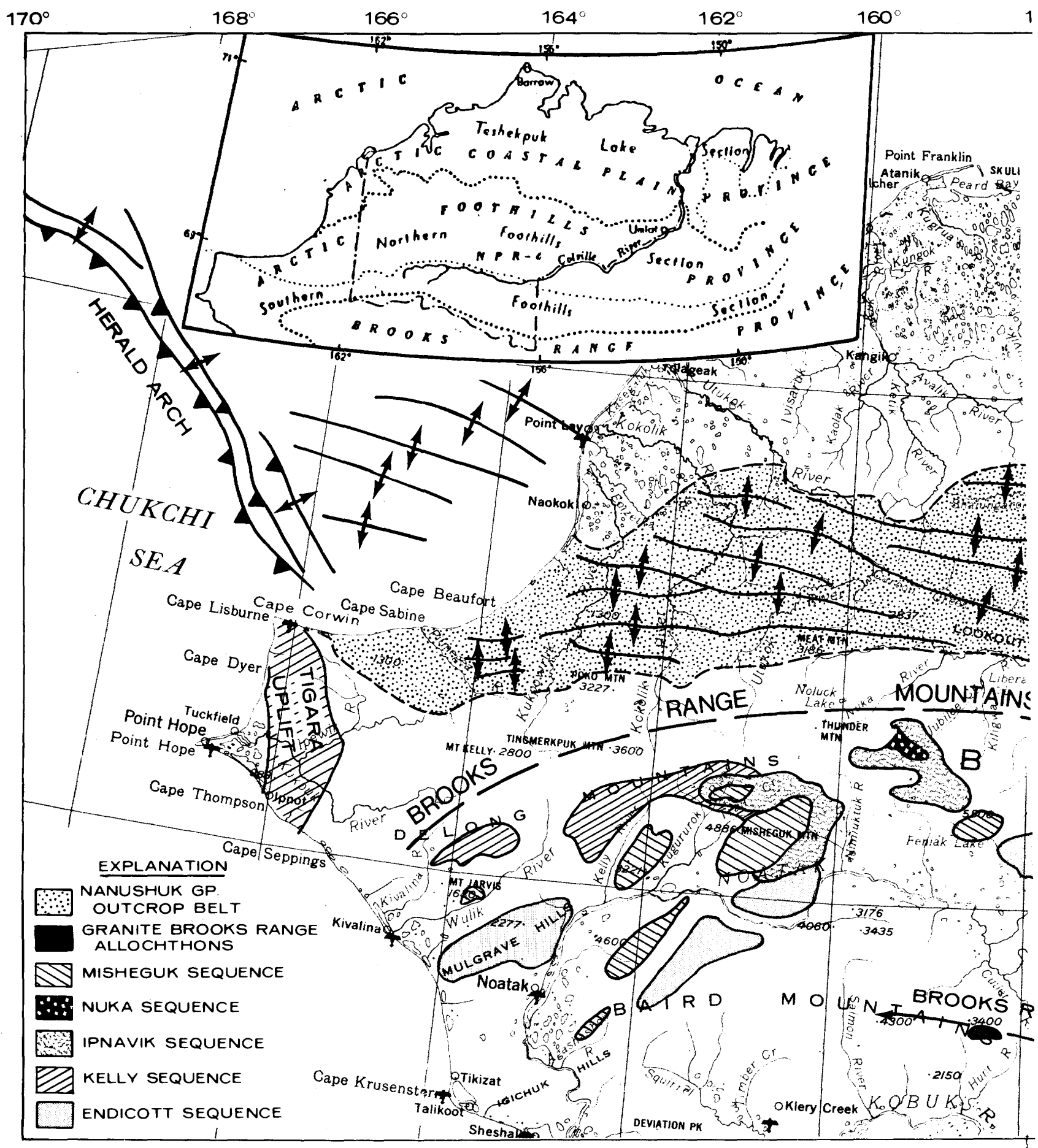

Figure 3.--Physiographic map showing major provinces and tectonic map showing approximate location belt, and major anticlinal axes in Nanushuk surface exposures. 


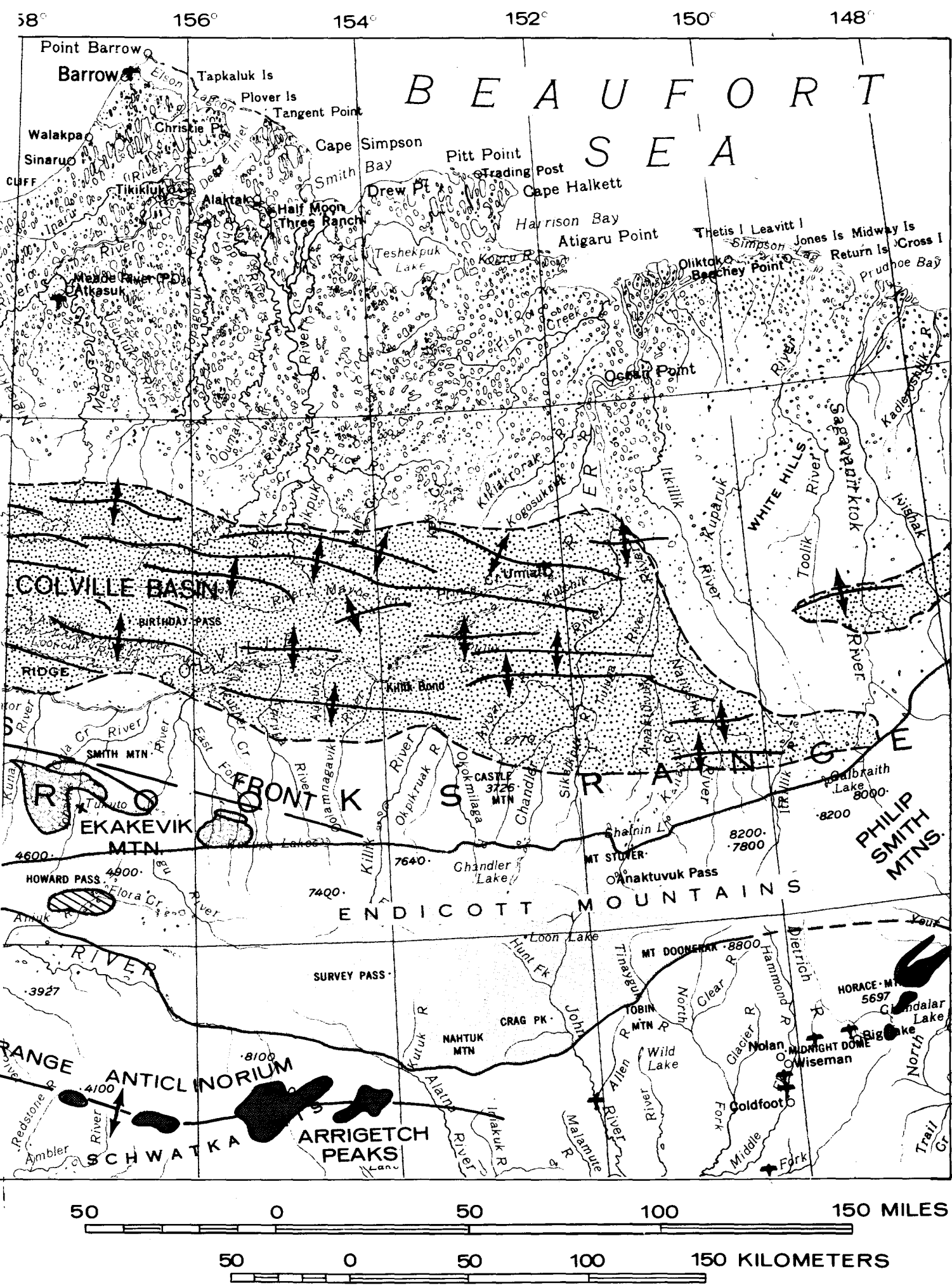

of major structural features, approximate distribution of major allochthons, the Nanushuk outcrop 
elsewhere on the Arctic Slope. This western area is frequently referred to as the UtukokCorwin area and, because of its better surface exposures, was the center of the initial outcrop studies in this project.

To the east of the Utukok-Corwin area, the Colville River rises in the foothills of the DeLong Mountains and has a generally east and northeasterly course for more than $360 \mathrm{~km}$ to near Umiat, where it turns sharply northward and flows toward the Beaufort Sea. For more than $160 \mathrm{~km}$, between long $160^{\circ} \mathrm{W}$. and $156^{\circ} \mathrm{W}$, , the upper Colville River flows south of the Nanushuk Group outcrop belt. As a result, the major Colville tributaries, which rise in the Brooks Range, do not cross the Nanushuk. From near the intersection of the Etivluk River with the Colville River and continuing eastward to the Umiat area, the Colville crosses the Nanushuk belt. The major tributaries to the Colville in this area--the Kurupa, Killik, Chandler, and Anaktuvuk Rivers--a11 of which rise in the high Endicott Mountains to the south, are incised into Nanushuk Group rocks. This area, referred to as the Chandler River area, contains fair to good exposures along the major streams.

North of the Colville River, exposures of the Nanushuk Group are generally poor. This area, which encompasses about one third of the Nanushuk outcrop belt, is drained by the Kuk, Meade, Topagoruk, Ikpikpuk, and Awuna Rivers and their tributaries. These rivers all head in a low rolling Nanushuk terrain about 300-500 $\mathrm{m}$ in elevation. The Kuk River trends northwestward into the Chukchi Sea; the Meade, Topagoruk, and Ikpikpuk drainages flow northward to the Beaufort Sea; and the Awuna flows eastward into the Colville River. Discharge on these streams is generally low and, as a consequence, incision into the Nanushuk terrain is Iimited and outcrops are generally poor and few in number. In addition, the detailed studies carried out in this project suggest that the Kuk-Ikpikpuk area may contain interdeltaic Nanushuk sediments (Ahlbrandt and others, this volume). The resulting sand-poor nature of the sediments may also contribute to the limited number of outcrops in this area. As a result of the 1imited outcrops, only limited field studies have been carried out in the KukIkpikpuk area of the Nanushuk outcrop belt. Most of the knowledge of the Nanushuk north of the foothills is derived from subsurface control from exploratory wells and from seismic data, as discussed in other chapters of this Circular.

\section{STRUCTURAL EVOLUTION OF THE BROOKS RANGE}

Deposition of the Nanushuk Group of the central and western Arctic Slope is closely tied to the evolution of the Brooks Range orogenic belt during the Cretaceous. An understanding of this orogenic belt aids in understanding the nature of the sediment, its depositional environment, and the subsequent deformation of the Nanushuk Group. These factors strongly influence the potential for hydrocarbons in the Nanushuk Group both in NPRA and in adjacent areas. Generalizations and details of the structural and stratigraphic evolution of the area have been presented by many workers, including Tailleur, Brosgé, and Reiser (1967); Brosgé and Tailleur (1970, 1971); Tailleur and Brosgé (1970); Tailleur (1973); Snelson and Tailleur (1968); Rickwood (1970); Martin (1970); Detterman (1973); Mull (1977); Mull and Tailleur (1977); Mull and others (1976); and Mayfield and others (1978) and, in general, will not be repeated here. The following summary incorporates data presented by the above authors with unpublished observations and interpretations of the writer and others; it emphasizes the major tectonic events and features that appear to have had an influence on Nanushuk deposition.

\section{Neocomian-Aptian Tectonics}

Regional indications of the beginning of the Brooks Range orogeny are recorded in Lower Cretaceous sediments exposed within and adjacent to the DeLong and Endicott Mountains of the western and central Brooks Range. These sediments record the abrupt shift in sediment dispersal from a predominant northern source that persisted through the late Paleozoic and early Mesozoic to a major southern and southwestern source derived from a Cretaceous orogenic belt.

The orogenic belt exposed in the central and western Brooks Range is composed of multiple allochthonous sheets of mafic igneous and sedimentary rock; these are the rocks from which at least part of the sediment in the Nanushuk Group was derived (for example, the hypothesized "Corwin delta" of Ahlbrandt and others, this volume). Several major thrust sequences can be traced for over $400 \mathrm{~km}$ along the front of the mountains. Each sequence is composed of a distinctive suite of formations, most of which maintain a relatively uniform character within the sequence but differ markedly from coeval formations in other thrust sequences (fig. 4). The allochthons will be described in a section entitled "Brooks Range Allochthonous Sequences."

The Brooks Range allochthons were apparently developed as a result of counterclockwise rotation of a crustal plate (Tailleur and Snelson, 1969; Tailleur, 1973; Rickwood, 1970; Newman and others, 1977). Paleomagnetic data and regional reconstructions suggest that this plate, the Arctic Alaska plate, moved relatively southward and was obducted by oceanic crust at a south-dipping subduction zone (Mu11, 1977, p. B31). This apparent relative movement and the relationships of continental and oceanic crust suggest that the Brooks Range allochthons developed by underthrusting (Tailleur and Snelson, 1969) rather 
than by the more commonly visualized mode of overthrusting. Underthrusting involves the process by which slices are progressively detached from the downgoing slab as it approaches the subduction zone (Seely and others, 1974). In the Brooks Range allochthons, each thrust slice underthrusts rocks that were formerly more southerly facies equivalents. The resulting stack of allochthonous sheets in the Brooks Range thus consists of several thousand meters of imbricated sedimentary and minor igneous rocks overlain by a sheet of oceanic rock which is also imbricated.

\section{Neocomian-Aptian Sedimentation}

The sediments derived from this Lower Cretaceous orogenic belt constitute a thick section of rhythmically interbedded sandstoneshale sequences that contain many typical turbidite characteristics. In addition, at a number of localities, a sedimentary chaos or olistostrome is present as a part of or closely associated with the turbidite sequence. The olistostrome deposits are composed of a heterogeneous assemblage of exotic blocks of mafic igneous and sedimentary rocks. Where well exposed in the DeLong Mountains, the blocks are clearly encased in mudstone, graywacke, and associated channel conglomerates at sedimentary, not fault, contacts (Mull and others, 1976). In some cases the blocks exceed tens of meters in maximum dimension.

The total assemblage of flysch and massive olistostrome exceeds a kilometer in thickness and is typical of deposits derived from an active orogenic belt. Regional stratigraphic and structural data show that deposition accompanying the orogenic event was northward into the Colville basin, a deep asymmetric basin or foredeep. The regional relationships also indicate that the orogenic belt and foredeep migrated progressively northward (Snelson and Tailleur, 1968), so that earlier orogenic deposits were themselves subsequently involved in the orogeny and, in places, were in turn eroded to form later deposits.

The sedimentary rocks that make up the allochthonous sheets of the orogenic belt range in age from mid-Paleozoic to Neocomian. Fossils contained within the flysch portion of the allochthons range in age from Berriasian to Valanginian. Although Aptian rocks have long been suspected to be present, definite Aptian fossils have not been reported from orogenic sediments of the Brooks Range thrust belt. However, Aptian fossils are reported from probable equivalent rocks of the basal Torok Formation in wells drilled in the area of the northern foothills and coastal plain of NPRA (Anderson, Warren, and Associates, written commun., 1977-78). In addition, in some places, evidence indicates that Neocomian orogenic sediments have also been displaced and telescoped by extensive thrust faulting. Thrustfaulted sequences containing rocks as young as
Neocomian are unconformably overlain at several localities (for example, Ekakevik, Fortress, and Castle Mountains) by thick lower Albian conglomerates of the Fortress Mountain Formation. This relationship, which is best illustrated at Ekakevik Mountain in the southeastern part of NPRA (Tailleur and others, 1966; Hunter and Fox, 1976), suggests that the major orogenic activity which formed the Brooks Range was preAlbian in age, began during Berriasian time, and continued into the Aptian.

\section{Pre-Nanushuk Cretaceous Stratigraphic Nomenclature}

Stratigraphic nomenclature within the Lower Cretaceous orogenic sediments is very generalized and not well established. Names and inferred relationships are shown in figure 2. In the orogenic belt, the name okpikruak Formation has been applied to the thick rhythmic flysch of Berriasian Age (Patton and Tailleur, 1964) that is characteristic of some of the thrust sequences. Additional Lower Cretaceous facies in other thrust sequences, consisting dominantly of graywacke, have not been formally named.

On the shallow northern flank of the Colville basin, Neocomian rocks correlative with the okpikruak Formation are informally called the "pebble shale" (Alaska Geological Society Newsletter, 1978; Bird and Andrews, this volume) and consist of black organic shale which locally has a thin basal sandstone. Where penetrated in wells drilled in the coastal plain, the "pebble shale" maintains a relatively constant thickness of about $100 \mathrm{~m}$.

In the subsurface of the coastal plain and northern foothills, the "pebble shale" is overlain by a thick dominantly shale sequence named the Torok Formation (Gryc and others, 1956). South of the coastal plain, seismic data indicate that this interval increases greatly in thickness and, where seen in outcrop in the southern foothills, commonly consists of rhythmically and thinly interbedded sandstone and shale that have many turbidite characteristics. Part of this flysch-like section is apparently equivalent to the coarse conglomeratic proximal deposits of the Fortress Mountain Formation (Patton, 1956). Along the north flank of the Delong Mountains, the lower part of the Torok grades downward and perhaps southward into a distinctive calcareous flysch containing conspicuous amounts of detrital muscovite. The upper part of the Torok Formation grades upward into the Nanushuk Group.

\section{Albian to Late Cretaceous Tectonics}

Regional mapping, combined with stratigraphic and structural studies throughout the Brooks Range, indicates that the Early Cretaceous stage of intense crustal shortening was followed by a stage of broad folding and smaller scale faulting that warped and deformed 
the pre-existing thrust sheets. This stage of deformation may be related to the intrusion of a series of granitic plutons in the Schwatka and Baird Mountains of the southern Brooks Range. These plutons have Cenomanian to Turonian cooling ages, indicated by potassiumargon dating (Pessel and others, 1973; Brosgé and Reiser, 1971; Turner and others, 1978), although lead-alpha dates from granite in the Chandalar area and regional structural relationships suggest that an early Paleozoic intrusive event also occurred in the area. The potassiumargon dates suggest that the core of the Brooks Range was mobilized and subjected to dominantly vertical uplift beginning in the Albian, after the stage of Neocomian-Aptian crustal shortening and thrust tectonics. This event coincides with the deposition of the Nanushuk Group.

The greatest amount of intrusion and vertical uplift occurred in the Arrigetch Peaks-Mt. Igikpak area of the Schwatka Mountains in the south-central portion of the Brooks Range. To the west, the surface exposures of the granitic intrusions become progressively smaller and lower in elevation, and so, regionally, the core of the range is a broad, westplunging anticlinorium that has autochthonous or parautochthonous rocks exposed along the axis. The sediments and mafic igneous rocks on the allochthonous sheets that flank the north side of the core of the range also define the same regional west-plunging character. As a result, progressively higher allochthonous sequences are found westward down the plunge of the regional anticlinorium into the DeLong and Baird Mountains. The presence of numerous allochthonous sequences in the western Brooks Range and the absence of many of the allochthons to the east are probably due not to their original distribution, but to the increased amount of subsequent vertical uplift and erosion to the east. This sequence of events within the Brooks Range, which affected the preexisting allochthons, probably played a large role in the type of sediment and style of deposition in the Nanushuk Group.

\section{Nanushuk Sediment Provenance}

In order to more fully understand the reasons for the character of the Nanushuk sediments described in detail in other chapters of this Circular, the nature of the source of the detritus must be examined.

Geologists have long recognized that the Nanushuk sequence progrades and thins northward and eastward over the Arctic Slope (Payne and others, 1952; Chapman and Sable, 1960). Along the outcrop belt in the foothills of the central Brooks Range, the source of the detritus appears to be from the south. However, in the western DeLong Mountains foothills, pronounced northeastward thinning and progressively finer grained sediments in the Nanushuk Group suggest a component of source derived from the west.
Paleotransport interpretations from outcrop data gathered during this study support northeasterly progradation in the Utukok-Corwin area (Ahlbrandt and others, this volume). In the area of the Arctic Coastal Plain, seismic and subsurface data show a clearly defined progradation to the northeast and east (Bird and Andrews, this volume). In addition, two different sediment source areas are suggested by stratigraphic and petrologic studies of Nanushuk sediments in the Utukok-Corwin area and Chandler River area (Ahlbrandt and others, this volume; Huffman, this volume; Bartsch-Winkler, this volume). The evidence thus suggests that the source of clastic material in the Nanushuk Group is from both the Brooks Range to the south and the northwest-trending Tigara Uplift in the area of Cape Lisburne (Payne, 1955), as well as its offshore extension beneath the Chukchi Sea, the Herald Arch, which has been mapped by Grantz and others (1970, 1976). Although the exact character of the rocks making up the offshore Herald Arch is unknown, good regional data are available for the Tigara Uplift and the DeLong and Endicott Mountains of the main Brooks Range. In the discussion which follows, the allochthonous sheets of the western and central Brooks Range are described in sequence from the top down, because this is the order in which they were eroded and progressively became sources of detritus that was deposited as the Nanushuk Group. The vertical sequence of the allochthons is illustrated in figure 4; their present outcrop distribution is shown on figure 3 .

\section{Brooks Range Allochthonous Sequences}

The uppermost of the Brooks Range allochthons, the Misheguk sequence, is an igneous complex composed dominantly of altered, finegrained, mafic igneous rocks; coarse-grained gabbroic rocks; and lesser amounts of ultramafic rocks (Roeder and Mul1, 1978; Mayfield and others, 1978). These rocks are now present as isolated klippen with the tops eroded, but several kilometers of rock may have originally been present on this sequence. Locally, the base of the thrust sequence is marked by isolated slivers of Middle Devonian limestone, but these rocks constitute only a minute percentage of the entire volume of the thrust complex. The allochthon is presently exposed primarily in the western Brooks Range. It is probably not present in the central Brooks Range, but abundant mafic igneous and gabbroic clasts in the Fortress Mountain Formation and earlier Cretaceous conglomerates suggest that the Misheguk allochthon was formerly present in this area.

The Misheguk sequence is structurally underlain by the Nuka sequence, a distinctive series of Mississippian to Permian arkosic limestones, limestones, and sandstones (the Nuka Formation) (Tailleur and Sable, 1963; 


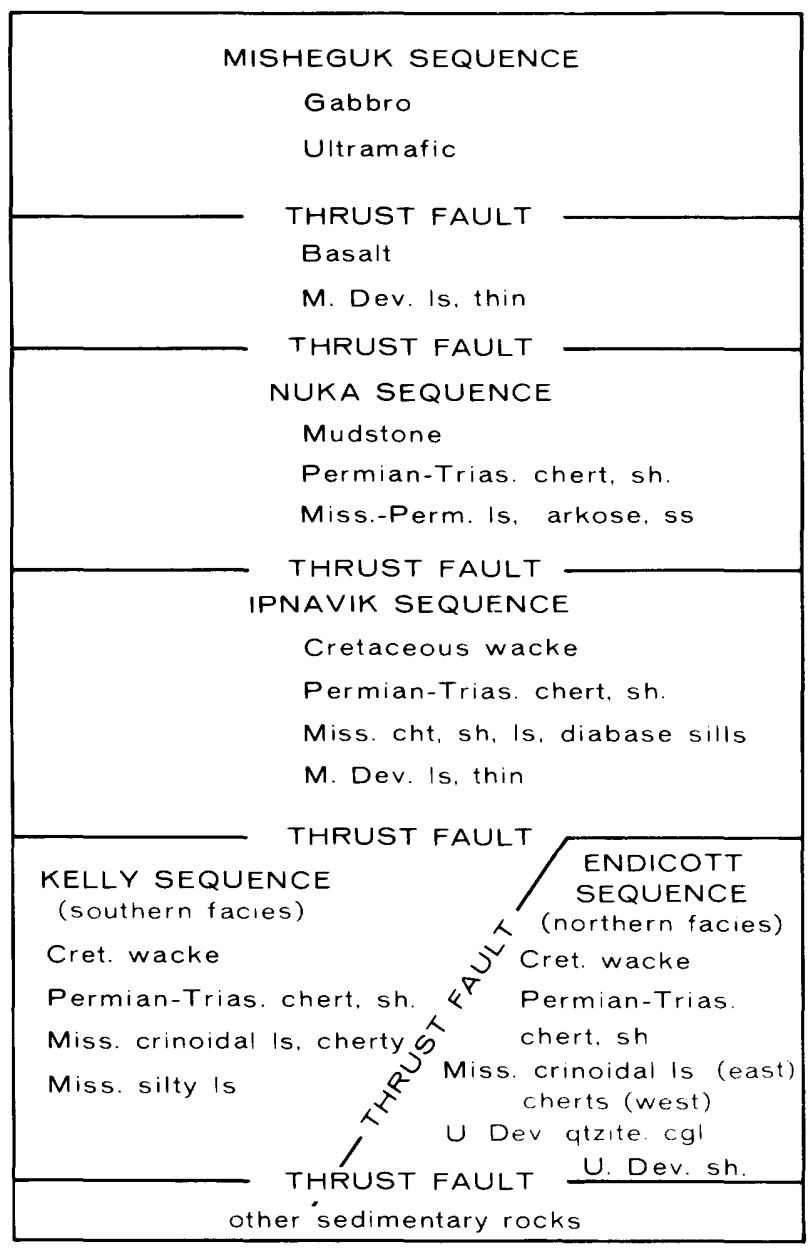

Figure 4.--Diagram showing vertical superposition of Brooks Range allochthonous sequences. In general, each sequence, when present, occurs in the same structural position relative to adjacent sequences. Each sequence represents southern facies equivalents of the rocks in the immediately underlying sequence, and has been telescoped relatively northward over the underlying sequence.

Tailleur and others, 1973), overlain by PermianTriassic cherts and siliceous shales, and having Mesozoic mudstone at the top. This sequence is less than $1 \mathrm{~km}$ in thickness and has a very limited present distribution in the western Brooks Range. Thin slivers of Middle Devonian limestones locally mark the base of the sequence.

Underlying the Nuka sequence is the Ipnavik sequence, a widespread series of dark Mississippian limestones, cherts, and siliceous shales intruded by numerous mafic sills and dikes. The Mississippian beds are overlain by PermianTriassic cherts and siliceous shales, and by Cretaceous graywackes. Minor Middle Devonian limestones locally mark the base of the sequence. The Ipnavik sequence has been exten- sively telescoped and, in some areas, exceeds 2 $\mathrm{km}$ in thickness. It is present as the major allochthon cropping out in the central and eastern DeLong Mountains. It is also present in the western Endicott Mountain foothills (Tailleur and others, 1966); isolated exposures as far east as the Anaktuvuk Pass area may also represent this sequence.

In the central and western DeLong Mountains, the Ipnavik sequence is underlain by the allochthonous Kelly sequence, composed dominant1y of Mississippian 1imestones containing numerous black chert nodules, some bedded chert, and silty to sandy limestones (the Kogruk and Utukok Formations of the Lisburne Group). This sequence also has thin PermianTriassic siliceous beds and Cretaceous graywackes at its top. In some places it is more than $2 \mathrm{~km}$ in thickness.

To the east, in the Endicott Mountains and foothills, the Ipnavik sequence is underlain by the Endicott allochthon, which forms the entire northern part of the Endicott Mountains. This allochthon is composed of a thick section of Upper Devonian quartzose sandstones, quartz and chert pebble conglomerates, and shales (the Kanayut Conglomerate and Hunt Fork Shale) overlain by Mississippian cherty limestones of the Lisburne Group. Permian-Triassic siliceous beds (Siksikpuk and Shublik Formations) and a thin, distinctive Lower Cretaceous (Valanginian) coquinoid limestone forms the top of the sequence. This allochthon is as much as several kilometers in thickness, of which the Upper Devonian section makes up at least one third. Although the sequence is widespread in the Endicott Mountains, it crops out only in local fensters through the overlying allochthons in the DeLong Mountains (fig. 3). The presence of the thick quartz-rich Kanayut sediments in the source areas of the central Brooks Range during Nanushuk sedimentation may explain the petrographic differences between the western and central Nanushuk sequences, which may relate to the different deltas described by Ahlbrandt and others (this volume) and Bartsch-Winkler (this volume).

In addition to the major allochthons discussed above, other thin sequences of limited distribution are also present. These allochthons are composed of thin slices of Mississippian rocks overlain by the Siksikpuk and Shublik Formations, and by Cretaceous graywackes, conglomerates, and shales. With the exception of the Cretaceous beds at the top, these allochthons are characterized by their predominant siliceous character.

The composition of the rocks of the Herald Arch is unknown, but the Tigara Uplift (Lisburne Hills) between Cape Lisburne and Cape Thompson provides possible information on the makeup of the Herald Arch. The Tigara Uplift consists mainly of thick limestones of the Lisburne Group, overlain by siliceous shales of the Lower Permian Siksikpuk Formation and thin shales and limestones of the Middle and Upper 
Triassic Shublik Formation. These rocks are overlain by thick Lower Cretaceous flysch similar to that of the main Brooks Range. The sequence in general is similar to the Kelly allochthon of the DeLong Mountains. East of the Lisburne Hills, Nanushuk sediments, consisting of shale, sandstone, and some very coarse boulder conglomerates, apparently unconformably overlie the earlier Cretaceous sediments. Northeasterly trending sediment transport directions, the very coarse nature of some of the conglomerates, and their proximity to the Lisburne Hills suggest that the conglomerates were derived from a source in the Tigara Uplift rather than from the DeLong Mountains. None of the higher allochthons of the DeLong and Endicott Mountains are present in the Lisburne Hills. However, several cobble-to-boulder conglomerate beds near Cape Corwin consist dominantly of chert clasts with occasional clasts of mafic igneous rock, granite, schist, Devonian limestone, oil shale, and other lithologies. The presence of these clasts suggests that the Tigara Uplift also contained displaced allochthonous sheets that have been stripped by subsequent erosion. If the Herald Arch is the offshore continuation of the Tigara Uplift, as the apparent structural trends suggest, multiple allochthonous sheets similar to those of the DeLong Mountains may have been present as part of the Nanushuk provenance in both the Tigara Uplift and Herald Arch beneath the Chukchi Sea.

\section{Summary of Nanushuk Sediment Sources}

Regional mapping suggests that at least most of the major allochthonous sequences discussed above were originally present as widespread sheets throughout the DeLong and Endicott Mountains. In areas in which no outcrops of some allochthons remain, their original presence is strongly suggested by conglomerate clasts and olistostrome blocks (olistoliths) found in pre-Nanushuk deposits. Regionally, mafic to ultramafic igneous rocks form the highest allochthon. Rocks containing abundant chert and siliceous beds are widespread in the intermediate allochthons, and rich quartz-bearing rocks are present only in the lowest allochthon, which is extensively exposed only in the Endicott Mountains in the central Brooks Range. Granitic and (or) high-grade metamorphic rocks of the Brooks Range core zone in the Schwatka Mountains area were apparently not exposed as a part of the source terrane for Nanushuk sediment.

Using the present vertical and lateral distribution of the various major rock types in the allochthons and making an extrapolation back in time to the Albian, generalizations concerning the sediment that should be expected to enter the Nanushuk depositional system can be made. Nanushuk sediment should show a general change in character as the source terrane was eroded and lower thrust sheets of differing character were progressively exposed to erosion. In the area north of the DeLong Mountains, basal Nanushuk sediments should show the effect of the abundance of mafic igneous detritus derived from the Misheguk and Ipnavik thrust sequences. Upwards, the Nanushuk should show the effects of a greater abundance of chert and other siliceous rocks derived from the Ipnavik sequence and from various Lisburne and Permian-Triassic rocks. However, even with the general abundance of chert in some horizons, the source terrane for the western part of the Nanushuk was highly deficient in stable detritus, as supported by petrographic studies by Huffman (this volume). The resulting sediment should be expected to be relatively sand poor, with a low sand-shale ratio. To the east, north of the Endicott Mountains, generally dirty sediment, indicating the influence of mafic igneous rocks and a quartz-deficient terrane, should be present at the base of the Nanushuk. Upwards, an increasing influence of the quartz-rich Upper Devonian Kanayut Conglomerate section in the source terrane should be seen in the Nanushuk, a concept supported by regional petrographic studies of Nanushuk sediments by Bartsch-Winkler (this volume). An increasing sand-shale ratio and some improvement in reservoir character of the sandstones should be expected as a consequence of the greater influx of quartz into the Nanushuk depositional system north of the Endicott Mountains.

\section{Nanushuk Structural Style and Hydrocarbon Exploration}

Regional mapping of the Arctic Slope indicates that much of the Cretaceous section beneath the southern part of the Arctic Coastal Plain and the northern foothills belt has been folded into a series of long, roughly eastwest-trending gentle synclines and sharp anticlines (Lathram, 1965; Beikman, 1976). In general, fold amplitudes decrease from south to north and die out in an area of essentially homoclinal dip beneath the Arctic Coastal Plain.

In the southern portion of the outcrop belt, most of the anticlines are breached through the Nanushuk Group into the underlying shale of the Torok Formation; in some places, south-dipping high-angle reverse faults or thrust faults cut the Nanushuk along the anticlinal axes. Although the underlying incompetent shales of the Torok Formation generally form very poor exposures, these shales, wherever exposed, are generally highly crumpled and contorted, in contrast to the gently dipping overlying Nanushuk. As a result of the observed contrast in deformation between the Nanushuk and the thick underlying Torok, the Nanushuk Group has long been interpreted as part of a decollement in which the relatively competent Nanushuk has been deformed independently from the underlying earlier Mesozoic and Paleozoic strata (Brosgé and Tailleur, 1971, p. 71). The zone of deformation or detachment was inferred 
to be the incompetent Torok Formation, and this has been confirmed by seismic data from NPRA and elsewhere that show relatively uniform south dip of Jurassic and older strata beneath the anticlines and synclines of the Nanushuk foothills belt.

Folding of the Nanushuk Group was probably an indirect result of the later stages of uplift and compression in the core of the Brooks Range. A possible minor gravitational component of movement of the Nanushuk northward off the Brooks Range uplift may also have contributed to the decollement style. Deformation of the Nanushuk probably began during early Tertiary or latest Cretaceous time and waned during the Tertiary. No clear evidence of deformation contemporaneous with either Nanushuk or Late Cretaceous deposition is known.

In the part of the foothills belt, generally north of the latitude of the Colville River at Umiat, where fold amplitudes decrease, the Nanushuk Group extends unbroken across the crests of the anticlines. The eastern portion of this belt of structures was the focus of much of the 1946-52 exploratory drilling by the U.S. Navy in Naval Petroleum Reserve No. 4 (now NPRA). Most of the exploratory wells at this stage of exploration tested closures evident in Nanushuk surface outcrops or identified from seismic data. In this area, results were generally discouraging, with discovery of only minor gas potential and of the relatively small Umiat oil field having recoverable reserves estimated at 70 million barrels. A1though large structures have been identified, a major obstacle to production has been the absence of thick reservoir beds. Exploration suggests that in the northern portion of the Nanushuk belt, in which the anticlines are unbreached and unfaulted, the sandstones are generally finer grained and tighter than to the south. In the southern portion of the belt, more proximal to the sediment source, the sandstones are coarser grained and are potentially better reservoirs, but are almost invariably breached to the surface. The result of these relationships, particularly in the eastern Nanushuk delta complex described elsewhere in this Circular, is a close race northward between improving structural setting and apparently decreasing reservoir quality. The major objective of the Nanushuk Group study thus has been an effort to identify the types and predict the distribution of potentially more favorable Nanushuk reservoir facies in the areas of most favorable structural setting. The more favorable reservoir facies have probably developed as a result of the interaction of sediment provenance and depositional environment.

Late Cretaceous and Tertiary Deposition

Regional compilations of geologic mapping of northern Alaska (Beikman, 1976; Lathram, 1965) and the results of drilling in NPRA show that post-Nanushuk deposits in northern Alaska are confined to the area of the coastal plain and northern foothills of the central and eastern Arctic Slope. No Upper Cretaceous or Tertiary rocks are known to be present on the Arctic Slope west of approximately long $157^{\circ} \mathrm{W}$. In the Umiat area, Upper Cretaceous deposits are relatively thin; but to the east of NPRA, in the vicinity of the Sagavanirktok River, the Upper Cretaceous section is more than $4 \mathrm{~km}$ in thickness. In the onshore areas of the depositional basin, Tertiary rocks are even more restricted in distribution than the Upper Cretaceous rocks, and outcrops are found still farther east and north of the majority of the Upper Cretaceous exposures.

In general, the areal distribution of Tertiary and Upper Cretaceous rocks relative to the distribution of the Lower Cretaceous rocks seems to record a continuation of the eastward and northward progradation seen in the Lower Cretaceous. Late Tertiary and Holocene erosion has resulted in stripping of some of these deposits. However, some evidence from the distribution of nonmarine facies in both the Upper Cretaceous and Tertiary suggests that the post-Nanushuk deposits may not have been deposited very far west and south of their present outcrop limits.

Although the magnitude, extent, and effect of late Tertiary and Holocene uplift and erosion are unknown, the evidence suggests that the Nanushuk deposits of the western Arctic Slope may have had a rather shallow and short burial history, in contrast to the much greater burial history of correlative beds in the eastern Arctic Slope. However, data from the Kugrua No. 1 and South Meade No. 1 wells drilled in 1978 in central and western NPRA on the western Arctic Slope indicate that the level of organic maturity is reached at a shallower depth than in wells to the east (Magoon and Claypool, this volume). The combination of indications of short burial history and shallow level of organic maturity suggests a higher thermal gradient, which may have implications concerning the hydrocarbon source potential and reservoir potential of at least the upper portion of the Nanushuk Group and perhaps deeper portions of the stratigraphic section on the western Arctic slope. 


\section{DEPOSITIONAL FRAMEWORK AND RESERVOIR-QUALITY STUDIES OF SELECTED NANUSHUK GROUP OUTCROPS, NORTH SLOPE, ALASKA}

By Thomas S. Ahlbrandt, A. Curtis Huffman, Jr., James E. Fox, and Ira Pasternack

\section{INTRODUCTION}

The Nanushuk Group can be traced as a gross lithologic unit from outcrops at Corwin Bluff along the Chukchi Sea eastward for approximately $650 \mathrm{~km}$ to the Sagavanirktok River southeast of Umiat (fig. 1). Exposures are largely confined to the Foothills north of the Brooks Range. Possible Nanushuk Group rocks have been reported east of the Sadlerochit Mountains in the Sabbath Creek area (Detterman and others, 1975). In the western North Slope area (west of long $158^{\circ}$ ), rocks of the Nanushuk Group are more continuously exposed than in the central or eastern regions, facilitating the interpretation of depositional environments there. Of the 22 sections measured during the 1977 field season, 19 were in the western area and 3 in the central.

The Nanushuk Group has previously been described in four separate areas: (1) in outcrop studies of the western area of the North Slope (Chapman and Sable, 1960; Smiley, $1966,1969 \mathrm{~b})$; (2) in outcrop studies of the central part of the North Slope (Gryc and others, 1956; Detterman and others, 1963; Chapinan and others, 1964; Brosgé and Whittington, 1966; Smiley, 1969a); (3) in outcrop studies of the eastern part of the North Slope (Detterman and others, 1975); and (4) in subsurface studies of wells in the NPRA (National Petroleum Reserve in Alaska) (U.S. Geological Survey Professional Paper 305-A to 305-L by Collins and Robinson, 1956-61). These studies of the Nanushuk have resulted in the development of different stratigraphic terminology for each of the areas (fig. 5). Integration of these studies is difficult, however, because of the absence of known fossil or lithologic datum horizons.

The Nanushuk Group, where examined in outcrop, is a regressive depositional sequence as much as $2,750 \mathrm{~m}$ thick that includes marine, transitional, and nonmarine intervals (table 1). Age determinations of the Nanushuk Group sediments, based on faunal and floral megafossil, pollen, dinoflagellate, and foraminiferal zonations, demonstrate a range from early Albian to Cenomanian (Imlay, 1961; Smiley,
1966, 1967, 1969a, b; Scott and Smiley, this volume; May, this volume; Tappan, 1962; Bergquist, 1966; Sliter, this volume). The facies of the Nanushuk Group are time transgressive, becoming younger to the north and northeast away from the Brooks Range (Chapman and Sable, 1960; Detterman and others, 1963; Brosgé

\begin{tabular}{|c|c|c|c|c|c|c|}
\hline \multicolumn{5}{|c|}{ OUTCROP } & \multirow{2}{*}{\multicolumn{2}{|c|}{ SUBSURFACE }} \\
\hline \multicolumn{5}{|c|}{ WEST } & & \\
\hline \multirow{9}{*}{ 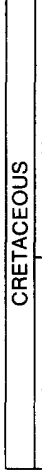 } & \multirow{9}{*}{ 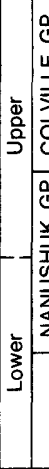 } & \multirow{2}{*}{ 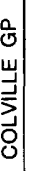 } & \multirow[t]{2}{*}{$\begin{array}{l}\text { Prince Creek (?) } \\
\text { Formation }\end{array}$} & $\left.\begin{array}{c}\text { Prince } \\
\text { Creek } \\
\text { Formation }\end{array}\right\rangle \begin{array}{c}\text { Schrader } \\
\text { Bluff } \\
\text { Formation }\end{array}$ & \multirow{2}{*}{ 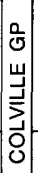 } & $\begin{array}{c}\text { Prince Creek } \\
\text { Formation } \\
\text { (Tuluvak Tongue) }\end{array}$ \\
\hline & & & & Seabee Formation & & Seabee Formation \\
\hline & & \multirow{4}{*}{ 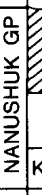 } & 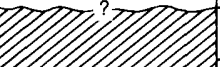 & $\begin{array}{l}\text { Chandler Formation } \\
\text { (Niakogon Tongue) }\end{array}$ & \multirow{5}{*}{ 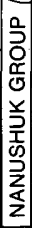 } & 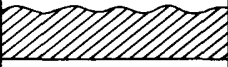 \\
\hline & & & 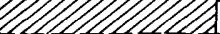 & Ninuluk Formation & & Ninuluk Formation \\
\hline & & & Corwin Formation & $\begin{array}{l}\text { Chandler Formation } \\
\text { (Killik Tongue) }\end{array}$ & & $\begin{array}{c}\text { Chandler Formation } \\
\text { (Killik Tongue) }\end{array}$ \\
\hline & & & Kukpowruk Formation & Grandstand Fm & & \multirow{2}{*}{ Grandstand Formation } \\
\hline & & & & Tuktu Formation & & \\
\hline & & \multirow{2}{*}{\multicolumn{2}{|c|}{$\begin{array}{l}\text { Fortress Mountain } \\
\text { Formation }\end{array}$}} & \multirow{2}{*}{$\begin{array}{l}\text { Torok Formation } \\
\text { Fortress } \\
\text { Mountain Fm }\end{array}$} & & Topagoruk Formation \\
\hline & & & & & & Oumalik Formation \\
\hline
\end{tabular}

Figure 5.--Stratigraphic nomenclature for the Nanushuk Group and adjacent rock units from the North Slope of Alaska, as used in outcrop studies (Chapman and Sable, 1960, p. 70) and subsurface studies (Collins, 1958a, p. 74). Time and stratigraphic correlation of units should not be inferred from this chart. Generalized stratigraphic relations for the western area of the North Slope are shown in figure 6 .

and Whittington, 1966; Smiley, 1969a, b; May, this volume). Generally, the Nanushuk conformably overlies the black and greenish-black shales of the Torok Formation of Albian Age (Imlay, 1961; May, this volume) and is unconformably(?) overlain by light-gray bentonitic units of the Colville Group of Cenomanian to Maestrichtian(?) age (Gryc and others, 1956, Bergquist, 1966; Smiley, 1969a).

Smiley (1966, 1967, 1969a, b) used plant megafossils to establish a floral zonation of the Nanushuk Group rocks. It is difficult, however, to use plant megafossils as zonal 
indicators in marine intervals or in subsurface intervals where cores are not available. Therefore, zonation of the Nanushuk Group using microfossils including spores and pollen (Scott and Smiley, this volume), dinoflagellates (May, and May and Stein, this volume), and foraminifera (Sliter, this volume) is underway to establish new reference sections or to complement existing ones.

Faunal megafossils are generally sparse and poorly preserved (generally only as molds or casts) and are, with very few exceptions, restricted to marine or brackish-water sandstones (D. L. Jones, oral commun., 1978). Megafaunal assemblages in the Nanushuk Group are identified in selected measured sections in this chapter. For a more complete megafaunal listing, see Chapman and Sable (1960) and Detterman and others (1963). Trace fossils, with the exception of borings of wood fragments and a few tracks, are also associated with marine or brackish-water deposits and were found extremely useful as aids in the interpretation of depositional environments.

The stratigraphic nomenclature used here includes the Nanushuk Group, with appropriate modifiers such as marine, transitional, or nonmarine, and the Torok Formation. The Torok Formation includes marine shales of Albian age over which the deltaic and interdeltaic sediments of the Nanushuk prograded. The subsurface terms Oumalik and Topagoruk Formations (for example, Collins, 1958a) are dropped in favor of the more widely accepted Torok Formation. Where previously defined stratigraphic names are used, the author who named or has most recently defined the unit will be cited.

The goal of this project is to determine the depositional framework and petroleum reservoir quality of the Cretaceous Nanushuk Group in northern Alaska. Statements in this chapter should be viewed as preliminary and of a reconnaissance nature owing to the short (2-year) duration of this project and the enormous region on the North Slope where rocks of the Nanushuk Group occur.

\section{PROCEDURE}

During the 1977 field season, 22 stratigraphic sections totaling $14,600 \mathrm{~m}$ were measured and described in detail (figs. 6, 7, table 1). Data recorded at the outcrop included color; sedimentary structures; bedding thickness; lamination types and style; biologic constituents including trace fossils; transport directions; scintillometer readings; and estimates of grain size, sorting, roundness, percent framework, interstitial cement, and porosity. Grain-size and rounding determinations were made in the field, using an American Stratigraphic Company visual grain-size comparison chart.

Data from the measured sections were recorded using a standardized format at a scale of $1.8 \mathrm{~cm}=1 \mathrm{~m}(1 \mathrm{in.}=10 \mathrm{ft})$. The data were subsequently encoded for computer display as shown for the Killik Bend section (appendix 1). Data from the remaining measured sections have been encoded in the same computer-drawn format. Subsurface core descriptions will be recorded using the same format as for the measured sections in order to facilitate subsurface and surface data synthesis. The computer-drawn displays show visual-porosity estimates of the sandstones that increase to the left from the 1ithology column to simulate a spontaneous potential curve (appendix 1, fig. 7). The grain-size column increases to the right from the lithology column to simulate a resistivity curve.

Laboratory analyses are currently being conducted on a total of 1,472 samples collected from the outcrops. These include 426 samples for petrographic, porosity and permeability, and delayed-neutron studies; 295 for organicgeochemistry analyses; 418 for dinoflagellate and pollen and spore content; and 285 for foraminifera content; 48 samples contain macrofossils and trace fossils. Data from these various efforts will be stored in a computer file at Petroleum Information Corp. in Denver, Colo., as they become available.

Data considered applicable to this chapter are summarized in table 1 . Stratigraphic relations are based primarily on those sections that have excellent exposures (table 1); more poorly exposed sections are useful mainly to demonstrate gross lateral changes. Sandstone and coal thicknesses probably represent minimum values for the poorly exposed sections. The locations of sections measured by the authors are shown on figure 1 and table 1 . Isopach maps of the Nanushuk Group incorporating both outcrop and subsurface data are presented by Bird and Andrews (this volume). Pelecypod identifications shown on figure 7 were made by D. L. Jones and J. W. Miller of the U.S. Geological Survey.

Sandstone samples were collected for reservoir-quality analysis on the basis of several criteria: (1) representative of the interval being sampled, (2) relatively free of weathering in order to minimize surface diagenetic effects, (3) without obvious fractures which could adversely affect permeability measurements, and (4) with a minimum sample dimension of $2.5 \mathrm{~cm}$. Although attempts were made to collect representative samples, the sampling was biased toward thicker and coarser grained units, considered to be potential reservoir intervals. Samples were oriented with respect to bedding by marking them with an "up" arrow for proper alinement of permeability tests either parallel or normal to bedding. Attempts to collect sandstone samples using a portable coring device proved largely unsuccessful. The coring rate was very slow and the plugs obtained were of a poor quality, having very irregular walls. The advantage of obtaining plug samples from depth behind the 
Table 1.--Synthesis of resource-related data from 1977

[M, marine; T, transitional; NM, nonmarine; thick., thickness; m, meters; ss, sandstone; \%, percent; no., number; ave.,

on

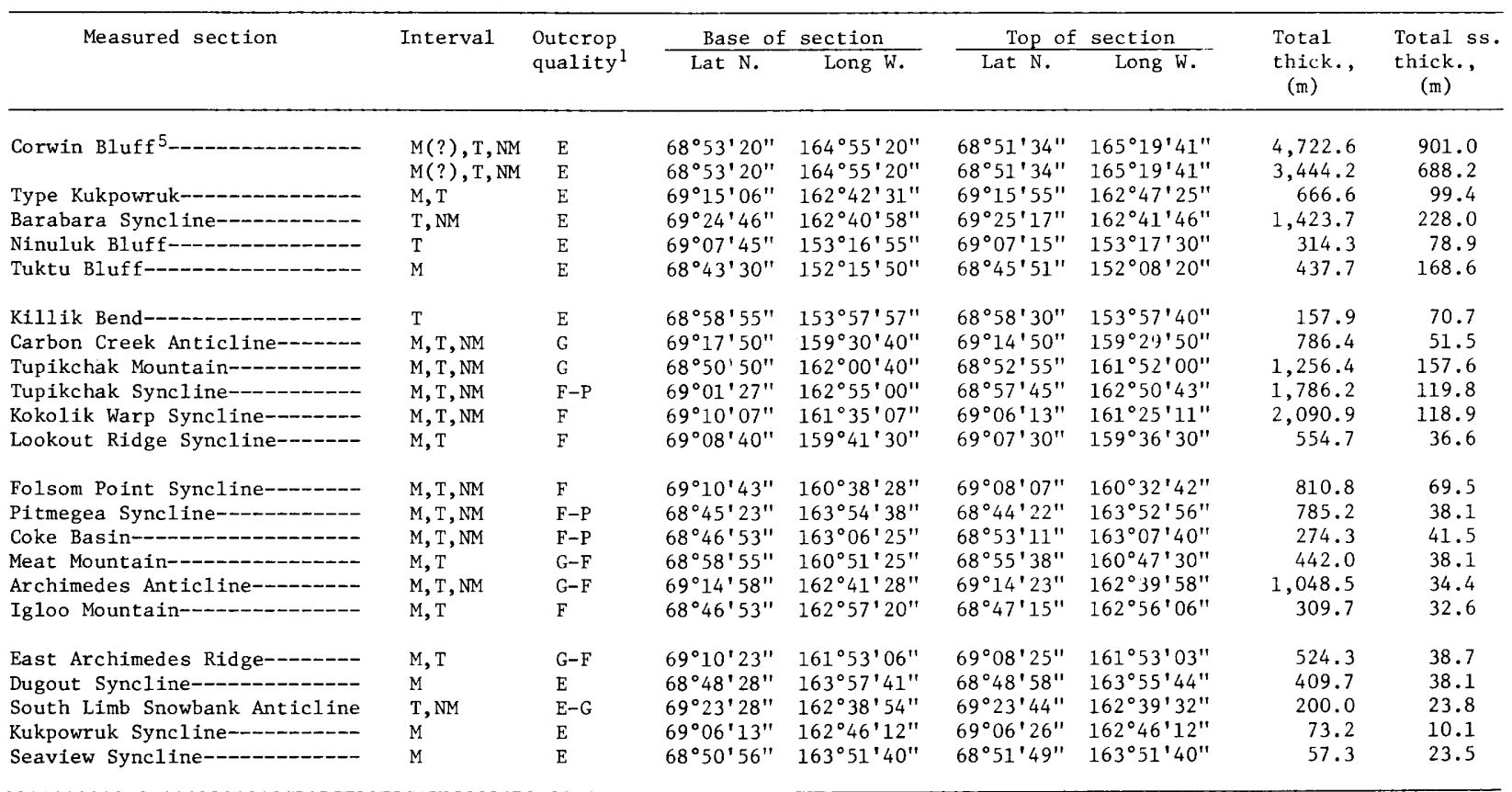

${ }^{1} \mathrm{E}$, excellent--completely exposed; G, good--mostly exposed, covered intervals minimal; F, fair--some covered, some well exposed; P, poor--mostly covered, resistant ledges exposed.

$24.3-\mathrm{m}$ coal bed and $30.5-\mathrm{m}$ fluviatile sandstone channel occur in river cut above top of measured section.

${ }^{3}$ Numbers in parentheses reflect number of samples measured.

${ }^{4}$ Samples having less than 8.0 percent porosity were not measured for permeability.

5 Thickness of this section reflects Chapman and Sable's (1960) original measured section and Smiley's (1969a) revised measured section, respectively.

${ }^{6} \mathrm{Slight}$ crack in sample.

outcrop surface was concluded to be negligible. The samples were prepared for porosity and permeability determinations in accordance with the procedures outlined in American Petroleum Institute Recommended Practices 40 (1960) and C. H. Wu (written commun., 1977). When possible, a $2.5-\mathrm{cm}$ plug was. cut parallel to bedding. For cases in which the dimension of the sample parallel to bedding was less than 2.5 $\mathrm{cm}$, the plugs were cut normal to bedding. The plugs were trimmed to a maximum length of 3.2 $\mathrm{cm}$ and were not extracted to remove residual hydrocarbons. This extraction step was omitted to expedite processing and because residual hydrocarbons were not observed during hand-lens or thin-section study of samples.

Porosity values were determined by measuring grain and bulk volumes. Grain volumes were measured using a Core Laboratories, Inc., Helium Gas Expansion Boyle's Law Porosimeter. A Ruska Instrument Corp. Universal Porometer was used to measure the bulk volumes. Porosities measurable using this equipment range from approximately 2 percent to 35 percent, with a repeatability of less than \pm 0.5 percent variation in porosity for regularly shaped, 3.2-cmlong plugs. Irregularly shaped or short plugs had a significantly higher variation, probably due to errors in bulk-volume measurements. The porosity values obtained for the latter type of plugs must therefore be considered only as approximations, and such data are not utilized in this paper.

Permeabilities were obtained for all plugs that had greater than 8 percent porosity. A Core Laboratories, Inc., Permeameter employing nitrogen gas as the testing fluid was used to determine the permeabilities. The minimum permeability measurable by the permeameter is approximately $0.01 \mathrm{md}$ with an accuracy of \pm 5 percent. A Klinkenberg Correction Factor was applied to all these measurements to obtain a more representative value of liquid permeability.

The testing methods outlined above are not strictly comparable to the methods reported in previous papers on the reservoir characteristics of sandstone samples from cores obtained as part of the National Petroleum Reserve No. 4 drilling program. The porosity values of the previous reports were determined by the Barnes vacuum method, which is considered not as accurate as the Boyle's Law expansion method. 
average; max., maximum; leaders (--) indicate not observed; n.d., not determined. Locations of measured sections are shown figure 1]

\begin{tabular}{|c|c|c|c|c|c|c|c|c|c|c|c|}
\hline \multirow[t]{3}{*}{ Ss. $\%$} & \multirow{3}{*}{$\begin{array}{c}\text { No. } \\
\text { ss. beds }\end{array}$} & \multirow{3}{*}{$\begin{array}{l}\text { Ave. thick. } \\
\text { ss. bed } \\
\text { (m) }\end{array}$} & \multirow{3}{*}{$\begin{array}{l}\text { Max. ss. } \\
\text { thick. } \\
\text { (m) }\end{array}$} & \multicolumn{5}{|c|}{ Sandstone reservoir parameters ${ }^{3}$} & \multirow{3}{*}{$\begin{array}{l}\text { Coal } \\
\text { thick. } \\
\text { (m) }\end{array}$} & \multirow{3}{*}{$\begin{array}{l}\text { No. } \\
\text { coal beds }\end{array}$} & \multirow{3}{*}{$\begin{array}{l}\text { Ave. thick. } \\
\text { coal beds } \\
\text { (m) }\end{array}$} \\
\hline & & & & \multicolumn{3}{|c|}{ Porosity $(\%)$} & \multicolumn{2}{|c|}{ Permeability (m) } & & & \\
\hline & & & & Range & Ave & & Range & Ave. & & & \\
\hline 19.1 & 278 & 3.2 & $24.4 \mathrm{NM}$ & $1.0-10.3$ & 4.98 & $(20)$ & $0.22-$ & $0.99(5)$ & $68.34 \mathrm{M}$ & 146 & 0.47 \\
\hline 19.8 & 220 & 3.1 & $24.4 \mathrm{NM}$ & $1.0-10.3$ & 4.98 & $(20)$ & $0.22-$ & $0.99(5)$ & 52.12 & 128 & .41 \\
\hline 14.8 & 29 & 3.4 & $24.4 \mathrm{NM}$ & $2.1-14.9$ & 7.05 & (3I) & $.09-\quad 2.26$ & $.63(13)$ & $\ldots$ & -- & -- \\
\hline 16.0 & 154 & 1.5 & $25.0 \mathrm{NM}$ & $.7-15.6$ & 8.28 & $(40)$ & $.12-28.01$ & $1.84(26)$ & 19.50 & 20 & .98 \\
\hline 25.1 & 33 & 2.4 & $13.1 \mathrm{~T}$ & $5.2-11.2$ & 8.11 & (16) & $.12-\quad 2.60$ & 1.14 (9) & +.27 & 11 & .39 \\
\hline 38.5 & 28 & 6.0 & $25.9 \mathrm{M}$ & $3.8-16.4$ & 7.43 & (17) & $.1-232.0$ & $58.18(4)$ & --- & --- & --- \\
\hline 44.8 & 24 & 3.0 & $14.6 \mathrm{~T}$ & $2.6-9.0$ & 5.58 & $(12)$ & $.89-20.11$ & 10.50 (2) & 4.88 & 12 & .41 \\
\hline 6.6 & 29 & 1.8 & $10.7 \mathrm{M}$ & $2.4-14.8$ & 8.31 & (16) & $.11-7.95$ & $2.13(8)$ & --- & $-\infty$ & -- \\
\hline 12.5 & 39 & 4.0 & $17.7 \mathrm{NM}$ & $.5-8.6$ & 5.99 & $(26)$ & $.10-\quad .80$ & .45 (2) & --- & --- & --- \\
\hline 6.7 & 42 & 2.9 & $19.8 \mathrm{NM}$ & $1.9-8.6$ & 5.24 & (16) & $.22-\quad .39$ & $.31 \quad(2)$ & --- & --- & --- \\
\hline 5.7 & 65 & 1.8 & $6.7 \mathrm{NM}$ & $2.7-13.4$ & 7.47 & (18) & $.07-22.8$ & $3.42(7)$ & 13.10 & 33 & .40 \\
\hline 6.6 & 13 & 2.8 & $8.8 \mathrm{M}$ & $.9-15.4$ & 6.56 & (12) & $.20-199.04$ & $66.80 \quad(3)$ & --- & --- & --- \\
\hline 8.6 & 22 & 3.2 & $18.0 \mathrm{~T}$ & $1.1-12.8$ & 7.32 & $(16)$ & $.08-1.0$ & .41 (8) & .31 & 1 & .31 \\
\hline 4.9 & 20 & 1.9 & $6.7 \mathrm{M}$ & $5.2-9.8$ & 7.00 & (8) & $.06-\quad .22$ & .14 (2) & -- & -- & -- \\
\hline 15.1 & 23 & 1.8 & $6.7 \mathrm{MM}^{2}$ & $.4-11.3$ & 4.93 & (12) & .42 & .42 (1) & $3.05^{2}$ & 7 & .44 \\
\hline 8.6 & 14 & 2.7 & $6.4 \mathrm{M}$ & $2.7-13.5$ & 8.43 & (18) & $.05-\quad .42$ & $.16(12)$ & --- & --- & --- \\
\hline 3.3 & 18 & 1.9 & $7.0 \mathrm{~T}$ & $2.1-3.6$ & 3.0 & (4) & n.d. ${ }^{4}$ & n.d. & --- & --- & --- \\
\hline 10.5 & 12 & 2.7 & $6.4 \mathrm{M}$ & $1.9-9.6$ & 5.33 & (10) & --- & $14.8(1)^{6}$ & --- & --- & -- \\
\hline 7.4 & 13 & 3.0 & $15.5 \mathrm{M}$ & $2.2-13.6$ & 8.47 & (11) & $.17-26.58$ & $5.65(5)$ & $\ldots$ & --- & -- \\
\hline 9.3 & 19 & 2.0 & $7.6 \mathrm{M}$ & $1.9-10.9$ & 6.19 & (20) & $.10-\quad 1.16$ & $.50(6)$ & --- & --- & --- \\
\hline 11.9 & 6 & 4.0 & $10.1 \mathrm{NM}$ & $1.4-14.5$ & 6.76 & (8) & $.19-\quad .84$ & $.56 \quad(3)$ & 3.35 & 11 & .31 \\
\hline 13.8 & 8 & 1.3 & $1.8 \mathrm{M}$ & $2.1-3.6$ & 3.0 & (4) & n.d. ${ }^{4}$ & n.d. & --- & -- & --- \\
\hline 41.0 & 4 & 5.9 & $9.5 \mathrm{M}$ & $2.3-8.6$ & 5.74 & (10) & $.04-\quad .24$ & $.14(2)$ & --- & --- & --- \\
\hline
\end{tabular}

\section{DELTAIC SEDIMENTATION}

Weimer (1970) listed eight criteria by which deltas may be recognized in the rock record, any two of which are sufficient to establish the former existence of a delta. These criteria include (1) complex intertonguing of marine (foreset and bottomset) and nonmarine (topset) strata; (2) rapidly changing shoreline sandstone trends from one time-stratigraphic interval to another; (3) arcuate lithofacies pattern of nonmarine strata protruding into the marine basin; (4) thickest deposits in the general shoreline area (topset and foreset) for a given time-stratigraphic unit; (5) greater abundance of stream deposits than of deposits of other environments of coastal plain; (6) lithologic criteria including repetitive sedimentary sequences combined with unusual concentrations of detrital carbonaceous material; (7) biological criteria in marine strata, notably the dominance of benthonic, arenaceous foraminifera rather than pelagic calcareous foraminifera; and (8) persistence of the above criteria in a vertical sequence, indicating that a semipermanent drainage produced the deposit. Because the Nanushuk Group meets most if not all of these criteria, we interpret it as being a deltaic and interdeltaic deposit with a generally southerly and southwesterly source. Two major depositional centers have been identified: a western one, here called the "Corwin delta," and an eastern one, the "Umiat delta."
Deltas are commonly divided into three categories, reflecting the dominant depositional process: river-dominated or high constructiona1, tide-dominated, and wave-dominated or high destructional. The "Umiat delta" has been called a river-dominated delta by Fisher and others (1969). The authors concluded that the Corwin delta also best fits the river-dominated delta category, based on the criteria summarized in Fisher and others (1969) and more recently in Miall (1976). Terminology used in this paper follows Fisher and others (1969) and Campbe11 (1971).

\section{CORWIN DELTA}

If we assume that the Nanushuk Group is delta-related, the most pervasive question deals with the location of the major loci of deposition. For the western region, we propose that a major depocenter was in the vicinity of Corwin Bluff. Rocks of the Nanushuk Group exposed at Corwin Bluff are the oldest, are the thickest, contain the coarsest material, and have the most nonmarine fossil assemblage of any rocks studied in the entire western region of the North Slope. Smiley (1969b), on the basis of plant megafossils, noted that the Nanushuk at Corwin Bluff ranges in age from early Albian to late Albian and becomes younger away from Corwin Bluff. For example, Smiley (1969b) indicated that Nanushuk is of middle Albian to Cenomanian(?) age along the Kukpowruk 


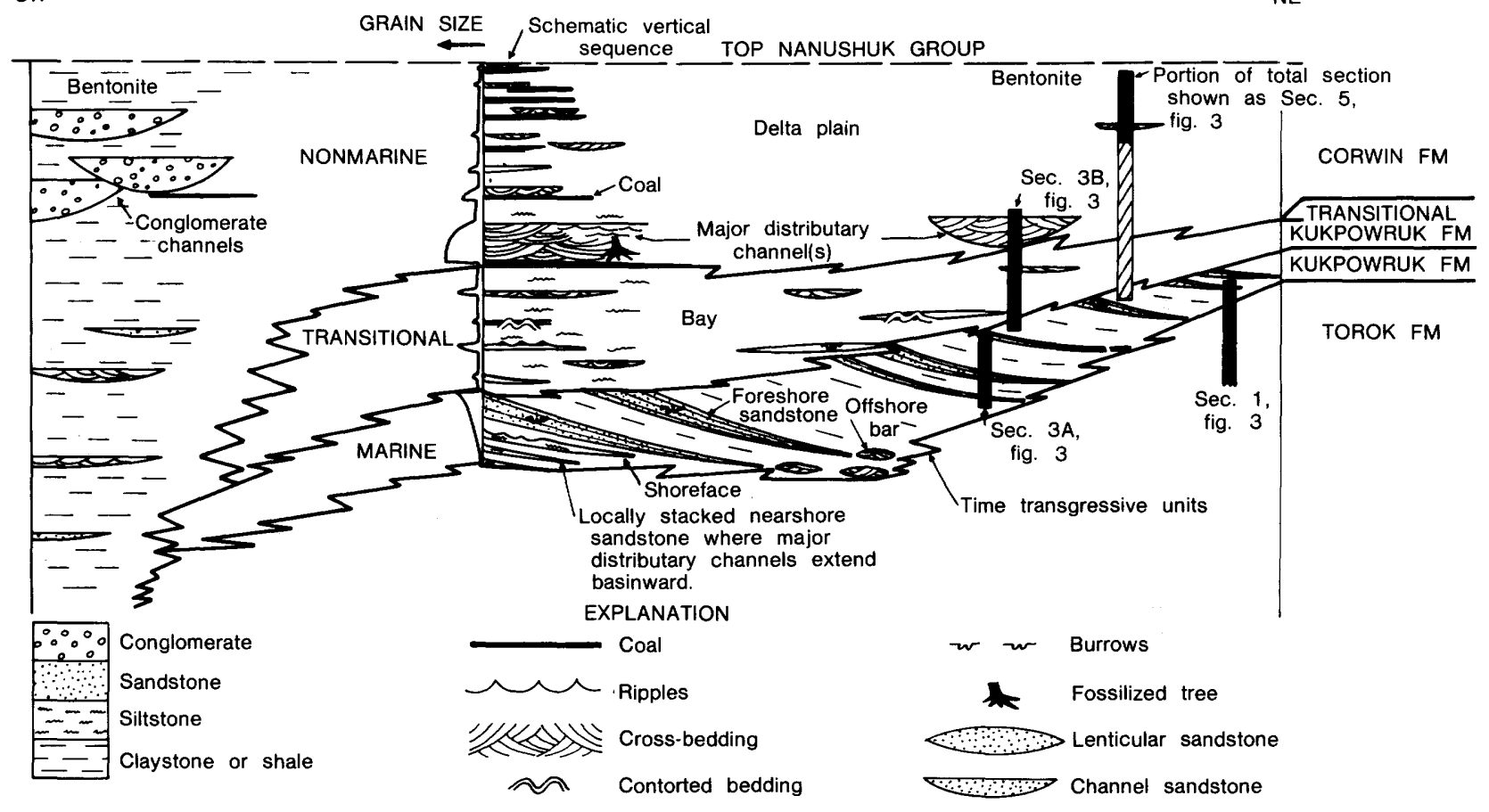

Figure 6.--Generalized sedimentologic sequence of Cretaceous Nanushuk Group rocks, western North Slope, Alaska. This sequence is applicable for all sections in the western area, with the exception of Corwin Bluff, where marine deposits are not well exposed.

Figure 7.--Measured stratigraphic sections in lower (sections 1, 2), middle (sections 3A, 3B, 4) and upper (sections 5,6) parts of the Nanushuk Group. Sections 1, 3A, 3B, and 5 are from the western area of the North Slope, and sections 2, 4, and 6 are from the central area. The ages of the sections are as follows: (1) Carbon Creek Anticline--Albian (undifferentiated) (Chapman and Sable, 1960), (2) Tuktu Bluff--middle and late Albian (Detterman and others, 1963; Smiley, 1969a; Sliter, this volume), (3) Type Kukpowruk--middle Albian and late Albian (Smiley, 1969b; Sliter, this volume), (4) Killik Bend--late Albian to Cenomanian? (Smiley, 1969a; Sliter, this volume), (5) Barabara Syncline--middle and late Albian (Smiley, 1969b), and (6) Ninuluk Bluff--Cenomanian (Detterman and others, 1963; Smiley, 1969a; Sliter, this volume).

River sections northeast of Corwin Bluff (vicinity of type Kukpowruk and Barabara Syncline sections, fig. 1).

The Corwin Bluff section was the thickest Nanushuk section of any of those measured. Originally, Chapman and Sable (1960) measured $4,723 \mathrm{~m}$ of section at Corwin Bluff and designated it the type section of the Corwin Formation. Smiley (1969b) recognized only $3,444 \mathrm{~m}$ as Corwin Formation at Corwin Bluff by interpreting repetition of section by faulting in the upper part of the sequence. We observed several other faults in the basal thousand meters of the Nanushuk Group in this section; however, $2,743 \mathrm{~m}$ of undisturbed section was measured.

Compared to other Nanushuk sections, the 194-m-thick conglomerate member of the Corwin
Formation (Chapman and Sable, 1960) exposed at Corwin Bluff is anomalous in the abundance and thickness of conglomerate-filled channels (as much as $38 \mathrm{~m}$ ), large size of clasts (as much as $30 \mathrm{~cm}$ ) within the conglomerates, and internal bedding character of the conglomerate channels. Fluvial channels in measured sections other than at Corwin Bluff show evidence of meandering (that is, lateral and vertical transition from trough crossbedding to overbank deposits) and contain much less conglomerate than at Corwin Bluff (less than several meters). Chapman and Sable (1960) used aerial photographs to trace a conglomerate bed $25 \mathrm{~km}$ inland, where it was truncated by a fault. We traced a conglomerate bed from Corwin Bluff $10 \mathrm{~km}$ east to Thetis Creek; in this distance the bed thinned from 15 $\mathrm{m}$ to approximately $1 \mathrm{~m}$. 


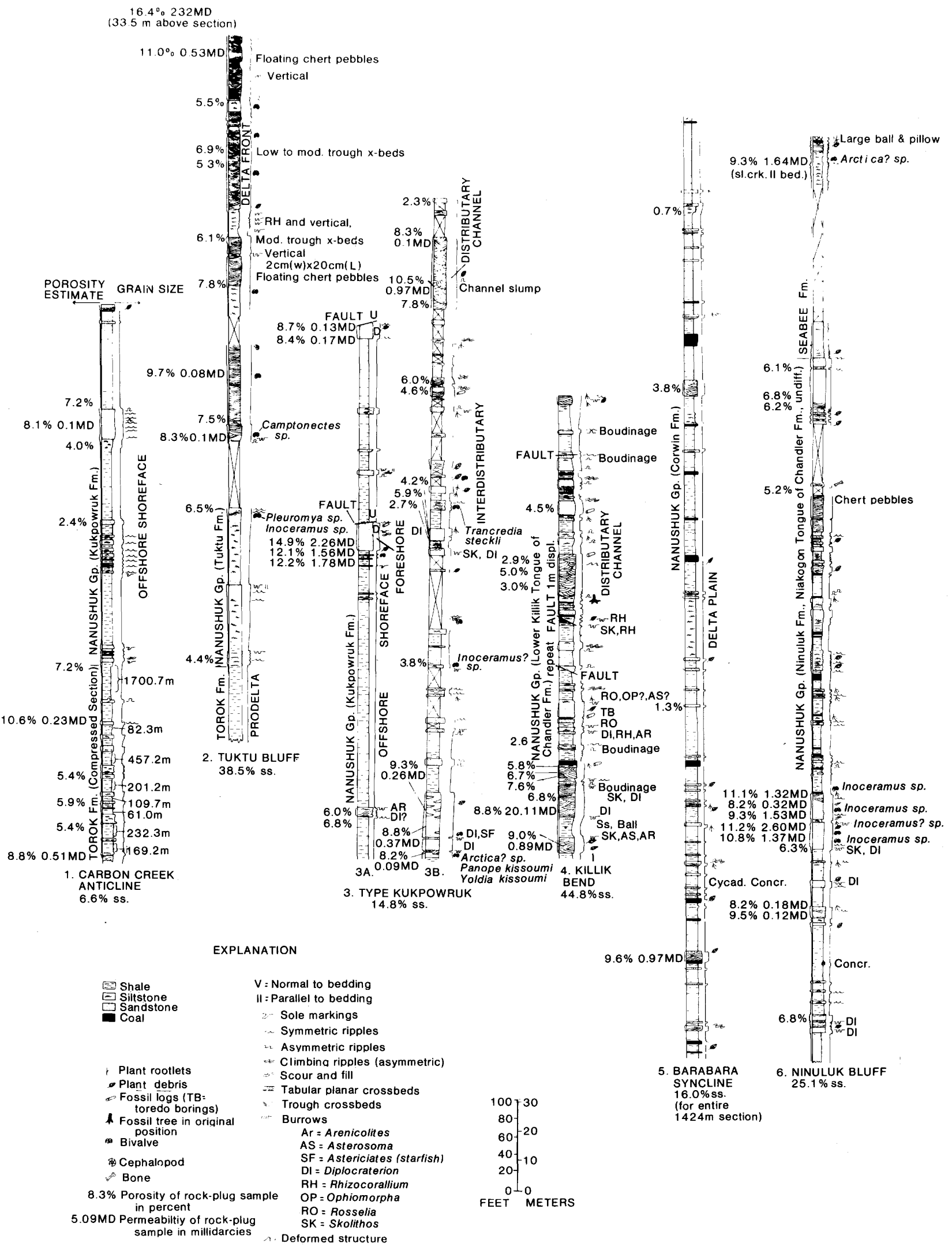


The clast composition of the Corwin Bluff conglomerates (described by Chapman and Sable, 1960) remains unchanged inland and is notable for the relatively low percentage of white quartz pebbles, the presence of fossiliferous carbonate clasts (1imestone of Lisburne Group?), and greenish-colored argillites. Maximum clast size decreases from about $30 \mathrm{~cm}$ at Corwin Bluff to less than $10 \mathrm{~cm}$ for the dark chert and fossiliferous carbonate clasts (limestone of Lisburne Group?) found elsewhere in the western area.

The Corwin delta apparently prograded northeasterly across the western North Slope and across areas now under the Chukchi Sea, as evidenced by paleotransport directions of Nanushuk channels (fig. 1). Such data agree with paleogeographic determinations of Payne and others (1952) and of Chapman and Sable (1960), and with the regional framework described by Grantz and Kirschner (1976) and Mul1 (this volume).

The western DeLong Mountains, Lisburne Hills, and their offshore extension, the Herald Arch (Grantz and Kirschner, 1976; Grantz and others, 1976; Mul1, this volume), are the most probable source terrains for the Corwin delta (see "Reservoir Quality" section; Huffman, this volume; Bartsch-Winkler, this volume). Although this chapter does not address the offshore Nanushuk rocks, the deposition and structural style of the Corwin delta are comparable for the western onshore area and the immediately offshore area in the Chukchi Sea (Mull, this volume). The depositional framework discussed in this chapter and the palynological zonation established by Scott and Smiley (this volume) at Corwin Bluff should be most useful for offshore Nanushuk studies.

Rocks of the Nanushuk Group, as observed in measured sections shown in figure 7, are typified by a sequence of marine $(100-300 \mathrm{~m})$, transitional $(100-300 \mathrm{~m})$, and nonmarine $(1,000-$ $2,700 \mathrm{~m}$ ) deposits schematically shown in figure 6. A series of sections measured in 1977 ( $\mathrm{fig}$. 7) illustrate the lower (marine), transitional (both marine and nonmarine), and upper (nonmarine) Nanushuk rocks in the Corwin delta (fig. 7, secs. 1, 3A, 3B, and 5, respectively). The basal contact of the Nanushuk Group with the underlying Torok Formation is picked at the lowest sandstone bed that is part of or grades upward into nearshore-marine sandstones. This placement is arbitrary owing to the intertonguing nature of the deltaic sediments. Siltstones and very fine grained sandstones occur at widely separated intervals within the Torok Formation (fig. 7, sec. 1).

In general, the basal sandstones (Kukpowruk Formation; Chapman and Sable, 1960) of the Nanushuk are wave-dominated. The sandstones grade upward into a transitional interval that represents lagoonal and (or) interdistributary trough fill (the transitional Kukpowruk of Chapman and Sable, 1960). These deposits in turn grade upward into nonmarine, delta-plain sediments (the Corwin Formation; Chapman and Sable, 1960) that are the dominant constituent of the Nanushuk in the Corwin delta.

Depositional environments of sandstones in the western area are differentiated primarily on the basis of sedimentary structures, lateral and vertical facies relations, textural variations, and trace fossil assemblages. The nearshore-marine sandstones include foreshore, shoreface, offshore-bar, and barrier-island deposits and generally increase in grain size from the base to the top of the deposit ( $f$ ig. 7, secs. 1, 3A). Shoreface sandstone beds are thin $(<3 \mathrm{~m})$ and commonly have contorted bases grading upward into low-angle crossbeds that have symmetrically rippled and bioturbated upper surfaces (fig. $8 A, B$ ). Common trace fossils include Gyrochorte (snail trails), Helicodromites (spiral burrows), Arthrophycus, occasionally Asterosoma, and unnamed large pelecypod(?) burrows (5-10 cm in diameter). The shoreface sandstones gradually become thicker upsection and are replaced by prominent foreshore sandstones (5-10 m thick) which are horizontally bedded to low-angle crossbedded and contain relatively few trace fossils, commonly Diplocraterion or Skolithos (fig. $8 \mathrm{C}$, D).

Foreshore sandstones are generally imbricated (separated by siltstones or shales), perhaps indicating rapid delta progradation, and grade laterally into isolated sandstone lenses that decrease in size basinward. The lenses, interpreted as being offshore bars, are commonly $<10 \mathrm{~m}$ thick and $60 \mathrm{~m}$ wide and have flat, gradational bases (fig. 6). Locally, foreshore sandstones are stacked where major distributary channels extended basinward, as exemplified by the Tupikchak Mountain section (fig. 1, 6).

The imbrication and direction of thinning of the basal Nanushuk marine sandstones were the subject of a detailed photogeologic study in the western region of the North Slope by Chapman and Sable (1960). They concluded that the basal, marine Nanushuk interval thins at a rate of $20.9 \mathrm{~m} / \mathrm{km}$ along a northeasterly vector (N. $32^{\circ}$ E.), the resultant of rates of thinning observed in 19 east-west and 16 north-south traverse studies. They further concluded that depositional strike (shoreline orientation) of Nanushuk marine sandstones was about N. $60^{\circ} \mathrm{W}$., which our paleotransport data support (fig. 1). Thus, in the Corwin delta the foreshore sandstones, offshore bars, and barrier islands are expected generally to have a northwestsoutheast orientation, and channels to have the preferred southwest-northeast elongation.

Deposits interpreted to be of eolian origin were observed in outcrops of the Meat Mountain and Folsom Point Syncline measured sections (fig. 1). In both locations, the deposits are oxidized (reddish-brown), moderate to high-angle, crossbedded, well-sorted, nonbur- 

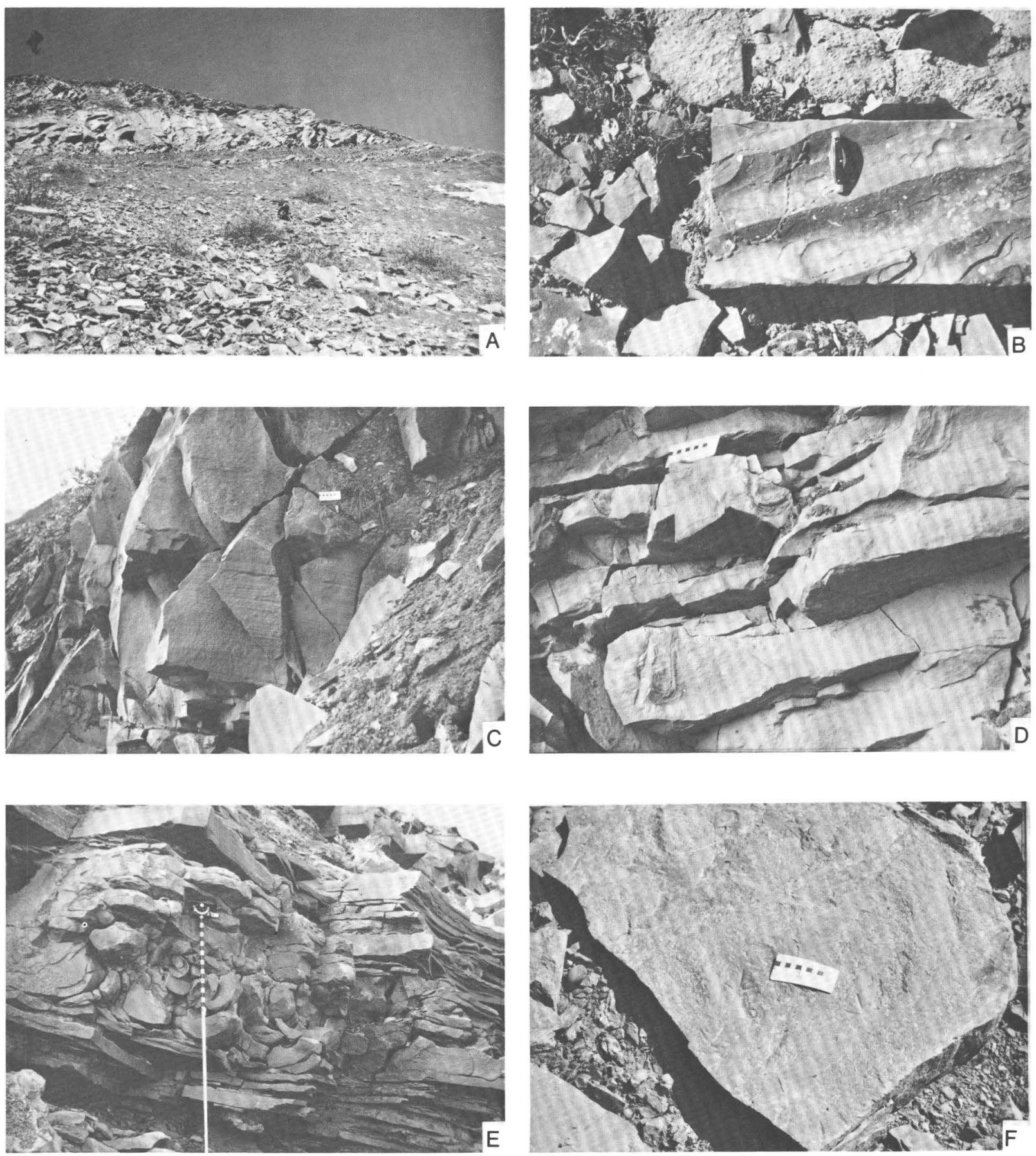

Figure 8.--Features observed in western Nanushuk Group exposures along the Kukpowruk River: $A$, basal exposures of Nanushuk at the type Kukpowruk Formation measured section; thin shoreface sandstones give way upsection to the thicker foreshore sandstone; man is $1.8 \mathrm{~m} \mathrm{tall;} B$, burrows (Helicodromites) crossing symmetrically rippled upper surface of one of the shoreface sandstones shown in $A ; C$, foreshore sandstone shown in $A$ with horizontal or low-angle crossbeds, 10-cm scale; $D$, vertical burrows (Diplocraterian) in foreshore sandstone at level of scale in $C ; E$, contorted beds in transitional interval (lagoonal) above sequence shown in $A$; and $F$, three-toed tracks in uppermost Nanushuk sediments, north limb of Barabara Syncline, lower Kukpowruk River. 
rowed, and fine-grained sandstone lenses. Such lenses overlie horizontally bedded foreshore sandstone beds and are overlain by mudstones. This sequence is interpreted as representing a barrier-island deposit.

Although most of the sandstones of the basal Nanushuk are wave-dominated, tidal channels were recognized at several localities. The channels observed in the Archimedes Anticline section (fig. 1) occur on the same horizon as a foreshore sandstone and contain low- to moderate-angle bimodally crossbedded sets. The channels, when traced laterally, grade to sandy siltstones that contain plant rootlets. At the axis of Lookout Ridge Syncline (fig. 1) pelecypods were recovered from basal lag deposits within fine-grained conglomerate tidal channels. The pelecypods had original shell material, and delicate features of the beak and shell ornamentation were preserved, indicating little transport.

Overlying the foreshore sandstones are transitional intervals that generally represent infill of interdistributary troughs (bays). Near the base of the transitional intervals, isolated, thin $(<5 \mathrm{~m})$ sandstones that contain marine trace fossils or megafossils are common, but they are found interspersed with nonfossiliferous, nonbioturbated channel sandstones that become more common upsection. Many of these marine (and probably brackish-water) sandstones are contorted and have ball-and-pillow structures (fig. 7, sec. 3B; and fig. $8 E$ ), are symmetrically rippled, and contain a variety of trace fossils including Arenicolites, Rosselia, Rhizocorallium, Diplocraterion, Asteriacites (starfish traces), plural tubes, and megafossils (fig. 7, sec. 3B).

Nonmarine sandstones occur as isolated channels, crevasse splays, and thin sheet sands of possible lacustrine origin. The major distributary channels are $10-30 \mathrm{~m}$ thick and commonly contain thin conglomerate beds or pebble lags with clasts of chert, carbonate clasts, and quartzite (fig. 7, sec. 3B). Fossil tree stumps in original growth position occur near the base of some channels. Most channel sandstones are 5-10 m thick, are less than $200 \mathrm{~m}$ wide, and consist of trough crossbed sets, in which grain size decreases upward and which laterally or vertically grade into asymmetric climbing ripple structures (fig. 7, secs. 3B, 5). Penecontemporaneous deformation is rare, except for minor channel-margin slumps; and trace fossils are limited to root traces, borings in fossilized logs, and very rare small three-toed dinosaur or bird(?) footprints (fig. $8 F$ ).

The upper part of the nonmarine section is interpreted as being deposited on a delta plain. Coals, as much as $4.3 \mathrm{~m}$ thick, are most common in this part of the section. Those measured sections that generally contain more coal and have much less sandstone and conglomerate are interpreted as being interdistributary basin (marsh) deposits (fig. 9, table 1). Those sections having greater amounts of coarser clastics are interpreted as having been along sediment supply routes. For example, the Tupikchak Mountain section is probably in a distributary lobe, whereas adjacent sections such as the Kokolik Warp section to the north or Tupikchak Syncline to the west are most probably interdistributary sequences and contain more coal and less sandstone and conglomerate (figs. 1 and 9, table 1 ).

The youngest beds of the Nanushuk Group at Corwin Bluff and on the north limb of Barabara Syncline are bentonitic. Smiley (1969b) redefined the type Corwin Formation at Corwin Bluff, indicating that the bentonitic clay member of the Corwin Formation as defined by Chapman and Sable (1960) was the youngest Nanushuk unit exposed there.

Very friable sandstones were observed on the north 1 imb of Barabara Syncline along the lower Kukpowruk River (1at $162^{\circ} 46^{\prime} 15^{\prime \prime}$ N., long $69^{\circ} 30^{\prime} 57^{\prime \prime}$ W.). The light-gray color, poor induration, and abundance of bentonite in the outcrops suggested to us that the unit was part of the Prince Creek Formation. Chapman and Sable (1960) described similar outcrops along the lower Utukok and Kokolik Rivers, which they called Prince Creek Formation (Upper Cretaceous). However, pollen and megaspore analyses show the friable Kukpowruk River samples to be of Albian age (see Scott and Smiley, this volume), and thus part of the Nanushuk Group. Petrographic, X-ray diffraction, and scanning-electron-microscopy studies all show montmorillonite to be rare in the Nanushuk samples except in the very uppermost Nanushuk samples (Bartsch-Winkler, this volume). The uppermost part of the Nanushuk in the Corwin delta is thus characterized by a sharp increase in montmorillonite--a feature also observed in the subsurface and Nanushuk sequences in the central North Slope area.

\section{UMIAT DELTA}

Rocks of the Nanushuk Group in the central North Slope area have previously received more extensive study than those in the west because of the greater availability of subsurface information from wells in the eastern part of NPRA, especially around the Umiat oil field. Reservoir problems in the Nanushuk at Umiat prompted early petrographic work on Umiat test wells 1 (Krynine, 1947, 1948) and 9 (Krynine and Ferm, 1952). A study by Fox and others (1979) discusses the Umiat 11 well in detail from the standpoints of depositional environment, petrography, and reservoir quality and is summarized by Fox in this volume. Additionally, biostratigraphic zonation of the Umiat 11 well by Sliter (this volume) and May (this volume) and organic geochemical data for this well by 

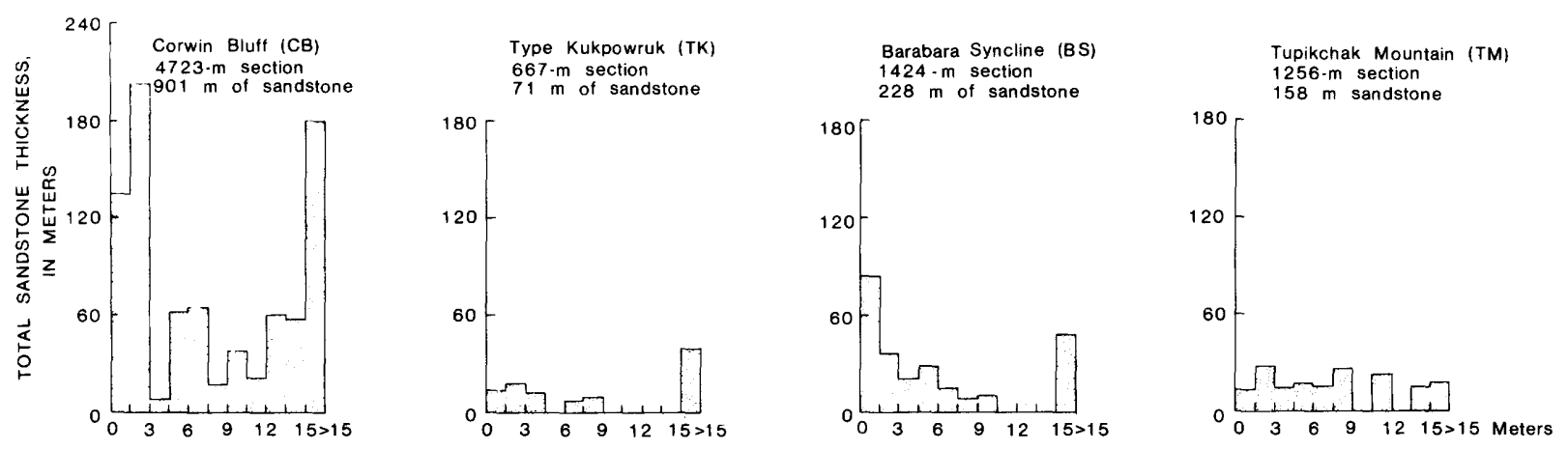

INDIVIDUAL-SANDSTONE-BED THICKNESS IN 1.5-M (5-FT) CLASSES
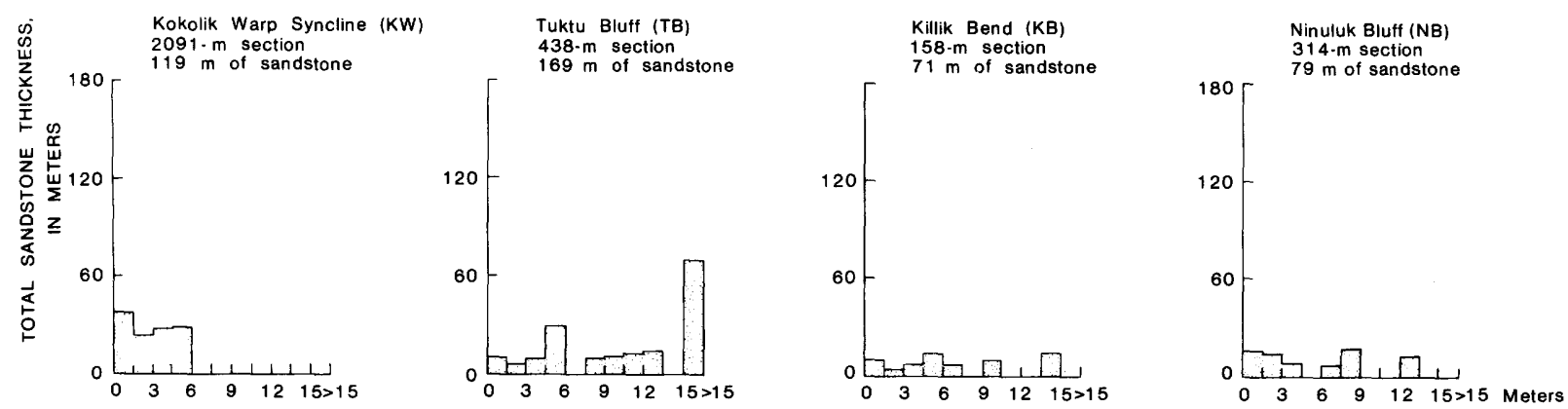

INDIVIDUAL-SANDSTONE-BED THICKNESS IN 1.5-M (5-FT) CLASSES
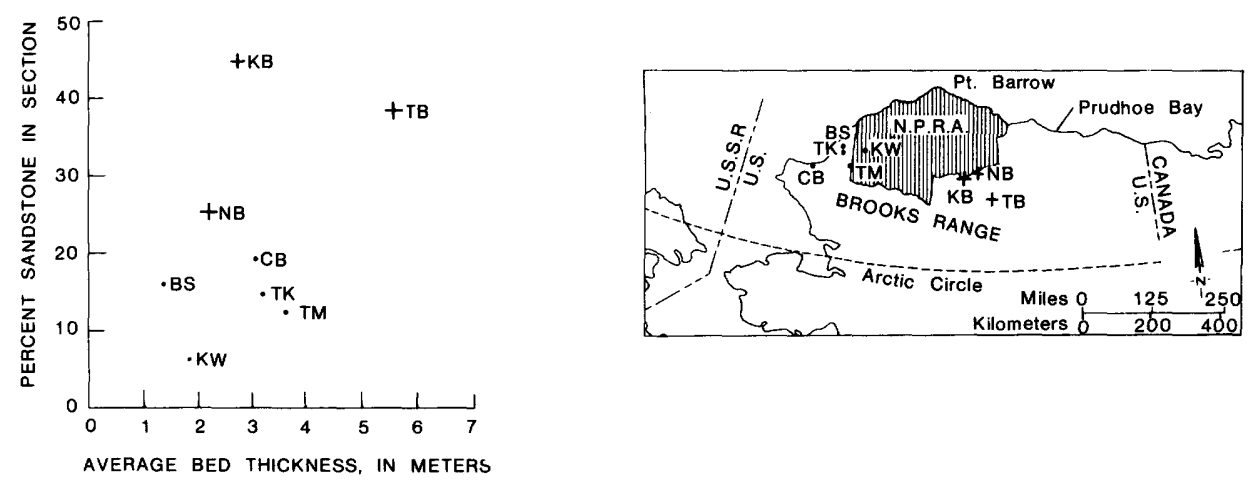

Figure 9.--A comparison of the thickness and percent of sandstones in five Corwin delta sections ( $\mathrm{CB}, \mathrm{TK}, \mathrm{BS}, \mathrm{TM}, \mathrm{KW}$ ) with those of three Umiat delta sections ( $\mathrm{KB}, \mathrm{TB}, \mathrm{NB}$ ). Sandstone is more common near major distributary channels (for example, $\mathrm{CB}$ ) or in distributary lobes (for example, TM) compared to interdistributary sections (for example, KW). The Umiat delta sections have relatively higher percentages of sandstone than do the Corwin delta sections.

Magoon and Claypool (this volume) will make the Umiat 11 well a reference section for the eastern part of NPRA.

The three sections measured by us in the eastern area (Tuktu Bluff, Killik Bend, and Ninuluk Bluff; fig. 7, secs. 2, 4, 6) permit a Iimited comparison between the Corwin and Umiat deltas (fig. 7, secs. 1, 3A, 3B, 5). The basal Nanushuk contact with the Torok Formation in the Umiat delta is sharp in contrast to the gradational contact at the base of the Corwin idelta (fig. 7, compare secs. 1 and 2). In the Tuktu Bluff section, prodelta deposits abruptly change upward into thick delta-front deposits. The delta-front deposits coarsen upward from siltstone to fine-grained sandstone at the top of the Tuktu Formation (as defined by Detterman. and others, 1963; see fig. 7, sec. 2). 
The middle part of Nanushuk strata in both deltas probably represents infilling of interdistributary troughs (bays) (fig. 7 , secs. 3A, 4). This stratigraphic sequence is represented in the Umiat delta by the Killik Bend section, which describes the lower part of the Killik Tongue of the Chandler Formation (as defined by Detterman and others, 1963). An important difference between the two deltas is that coals rest directly on marine (or brackish-water) sandstones in the Umiat delta, but coals only occur in the nonmarine (delta-plain) interval of the Corwin delta. The absence of coals in marine-transitional intervals of the Corwin delta may be explained by rapid progradation or lateral migration of streams of this delta, such that interdistributary troughs (bays) did not completely fill before being breached by distributary channels. Interdistributary troughs in the Umiat delta may have filled more completely, resulting in coals directly overlying the marine sandstones that developed around the margins of the bay.

The composition of conglomerate clasts in the Umiat delta is markedly different from that in the Corwin delta complex. At the type section of the upper part of the Killik Tongue of the Chandler Formation, north of Tuktu Bluff on the Chandler River, conglomerate units as much as $14 \mathrm{~m}$ thick are composed of 40 percent white, we11-rounded quartz pebbles and cobbles (Detterman and others, 1963). The striking color and compositional contrasts between conglomerates in the Corwin delta and those in the Umiat delta suggest a different provenance. Petrography of sandstones of the Nanushuk from both subsurface and outcrop samples demonstrate the relative absence of metamorphic rock fragments and a lower quartz content in the Corwin delta sandstones relative to the Umiat delta sandstones (Huffman, this volume; BartschWinkler, this volume). Such petrographic data suggest different source terrains, but paleotransport data are too limited to infer the direction of the Umiat delta progradation with absolute certainty. However, facies interpretations by Brosgé and Whittington (1966) suggest northeasterly progradation of the Umiat delta.

The intertonguing Ninuluk Formation and Niakogon Tongue of the Chandler Formation (Detterman and others, 1963) represent the uppermost part of the Nanushuk in the eastern area. At the type locality of the Ninuluk Formation, Ninuluk Bluff, the undifferentiated Ninuluk/Niakogon rocks are interpreted as representing a relative rise of sea level. marine pelecypods and trace fossils in the Ninuluk contrast sharply with the delta-plain sediments of the uppermost part of the Nanushuk in the west (fig. 7, compare secs. 5, 6); no similar age relation is inferred, however. The Ninuluk/Niakogon unit resembles the transitional intervals of either delta (fig. 7, compare secs. 3B, 4, 6). The Ninuluk is bentonitic, particularly high in the section, and the unconformably(?) overlying Seabee Formation is very bentonitic (Detterman and others, 1963) both in outcrop and in the Umiat 11 wel1 (Collins, 1958a).

\section{RESERVOIR QUALITY}

Assessments of reservoir quality of sandstone units of the Nanushuk in outcrop are based on quantitative porosity and permeability determinations from 345 sandstone samples in measured sections, as summarized in table 1 ; on petrographic studies (Huffman, this volume; Bartsch-Winkler, this volume), and on field studies of sandstone geometry.

Sandstones of the Nanushuk Group, where studied on the North Slope, are litharenites that produce carbonate cement and matrix detrimental to reservoir quality when subjected to compaction and diagenesis. Abundant clay matrix is a problem common to all of these sandstones. The virtual absence of swelling clay (montmorillonite) in all but the uppermost Nanushuk intervals in both outcrop and subsurface is important to reservoir-quality assessment (Bartsch-Winkler, this volume; Fox, this volume). This means, for example, that the freshwater muds used in some of the wells in the National Petroleum Reserve 4 (NPR-4) program did not adversely affect reservoir characteristics of most sandstones.

Sandstones of the Nanushuk Group in the western area, in general, are thin, discontinuous, and beset with diagenetic problems related to abundant unstable sedimentary rock fragments. Carbonate cement and argillaceous matrix greatly reduce permeability in these sandstones (Huffman, this volume). Three hundred samples from the 19 measured sections in the western area have porosity values ranging from 0.4 to 15.6 percent. Most samples are in the 5-8 percent porosity range, but 105 samples exceeded 8 percent porosity and were analyzed for permeability. Of these, 6 samples had permeability values greater than 5 millidarcies, 2 of these 6 samples have small fractures, and only 1 sample has greater than 30 millidarcies permeability (Lookout Ridge section). Reservoir data for an additional 72 miscellaneous outcrop samples fall within the porosity and permeability ranges noted above, with the exception of a channel sandstone in the uppermost part of the Nanushuk (maximum dimensions of $6 \mathrm{~m}$ thick and $50 \mathrm{~m}$ wide) that had excellent porosity and permeability values (Huffman, this volume). Subsurface Nanushuk samples from Kaolak 1, the on $1 y$ well that penetrates the Corwin delta complex, have porosity and permeability values comparable to those of the outcrop samples. Collins (1958a) reported porosity values for 14 samples from the Nanushuk interval of the Kaolak well (34.5-1,246.6 m depth interval in the well) ranging from 8.3 to 14.4 percent, and all samples are impermeable. Petrographic study of sandstones of the Nanushuk from both 
the Kaolak cores and western outcrop samples demonstrate similar rock composition and diagenetic alteration (Bartsch-Winkler, this volume). Overall, the Corwin delta has a low sandstone content and thin, laterally discontinuous sandstone beds (fig. 9, table 1). The single most important depositional unit from a reservoir standpoint is the foreshore sandstone(s) within the basal part of the Nanushuk Group. These sandstones are easily recognized by their prominent, original, nearly horizontal bedding and distinctive vertical burrows. Their predictable occurrences in the Nanushuk indicate the passage of the paleoshoreline. These highenergy environments have the best reservoir potential in the Corwin delta complex because they have (1) the best visible porosity in outcrop and best measured porosity and permeability (fig. 7, sec. 3A); (2) greatest maximum thickness ( $<25 \mathrm{~m}$, commonly $5-10 \mathrm{~m})$; (3) a possible adjacent hydrocarbon source (marine shale); (4) lateral continuity along the paleoshoreline; and (5) a relatively more stable composition due to removal of diagenetically unstable grains under relatively higher energy conditions (Fox, this volume; Huffman, this volume; Bartsch-Winkler, this volume). The foreshore, offshore-bar, and barrier-island sandstones should have a preferred northwestsoutheast orientation in the western area, which is useful for exploration. The Tupikchak Mountain section is the only area studied in which foreshore sandstones rest directly over one another, resulting in an 18-m-thick bed; however, porosity values are less than 9 percent and permeability values less than 1 md there.

Thus, considering the reservoir quality of the sandstones in the western area, prospects of major oil accumulations in the Corwin delta complex seem to be poor; porosity values are low to moderate. Thermal-maturation data in both western outcrop and subsurface samples (Magoon and Claypool, this volume) suggest that the Nanushuk is more prone to gas accumulations. However, low permeability and discontinuity of sandstones in the western area may even be a limitation on the size of reservoirs and rate of flow of potential gas production. Limited data suggest that the reservoir quality of sandstone units of the Nanushuk in the central North Slope area is better than to the west. Porosity values for 45 samples in three central sections range from 2.6 to 16.4 percent, and permeability values are as much as $232 \mathrm{md}$. Sandstones in the eastern area are thicker, constitute a greater percentage of the total sediments (fig. 9), and have a more favorable composition (more quartz sand, fewer sedimentary,rock fragments) than Nanushuk samples in the west (Fox, this volume; Huffman, this volume; Bartsch-Winkler, this volume). Investigations in the coming year will focus on outcrops in the central and eastern areas of the North Slope. 


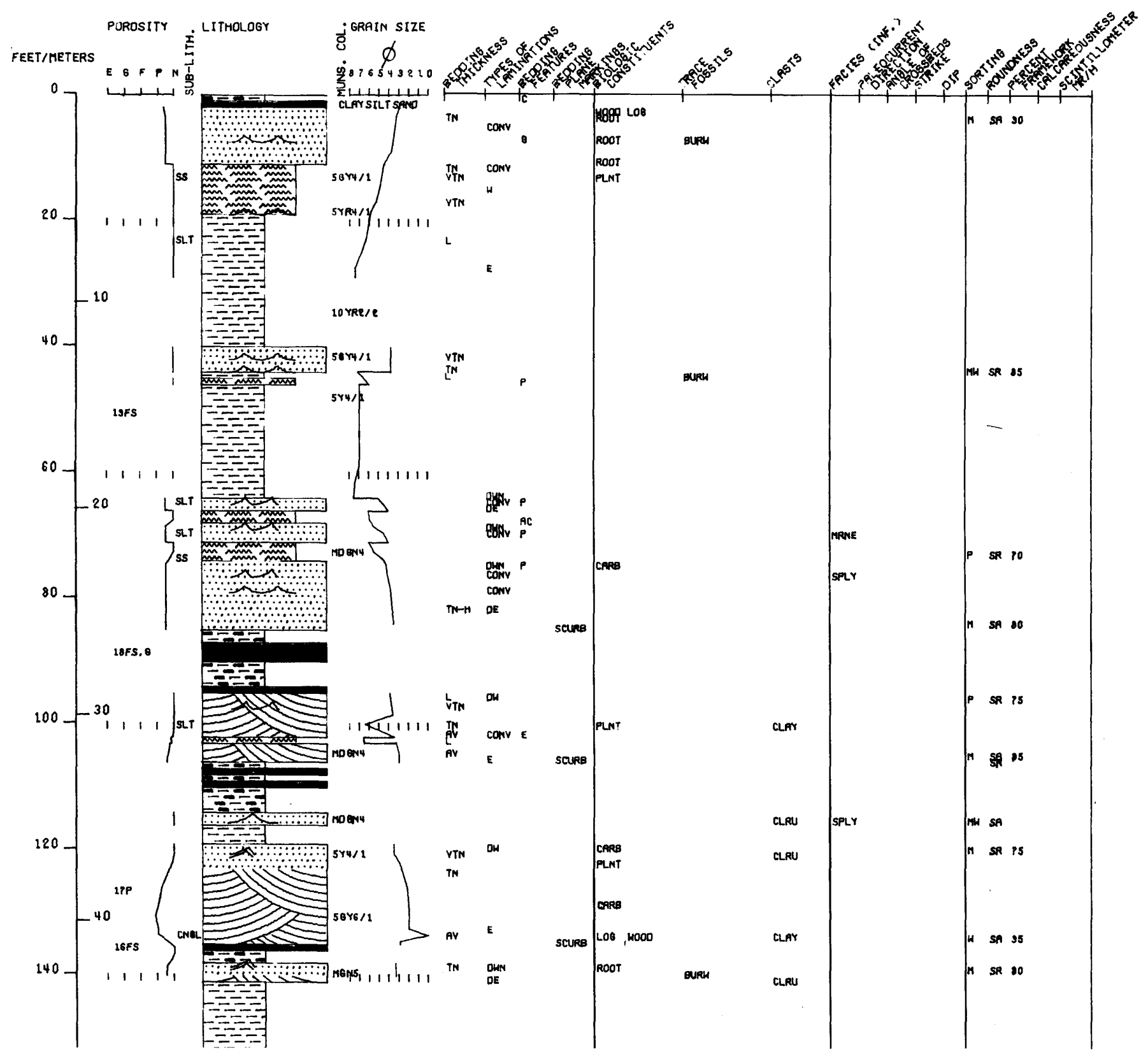



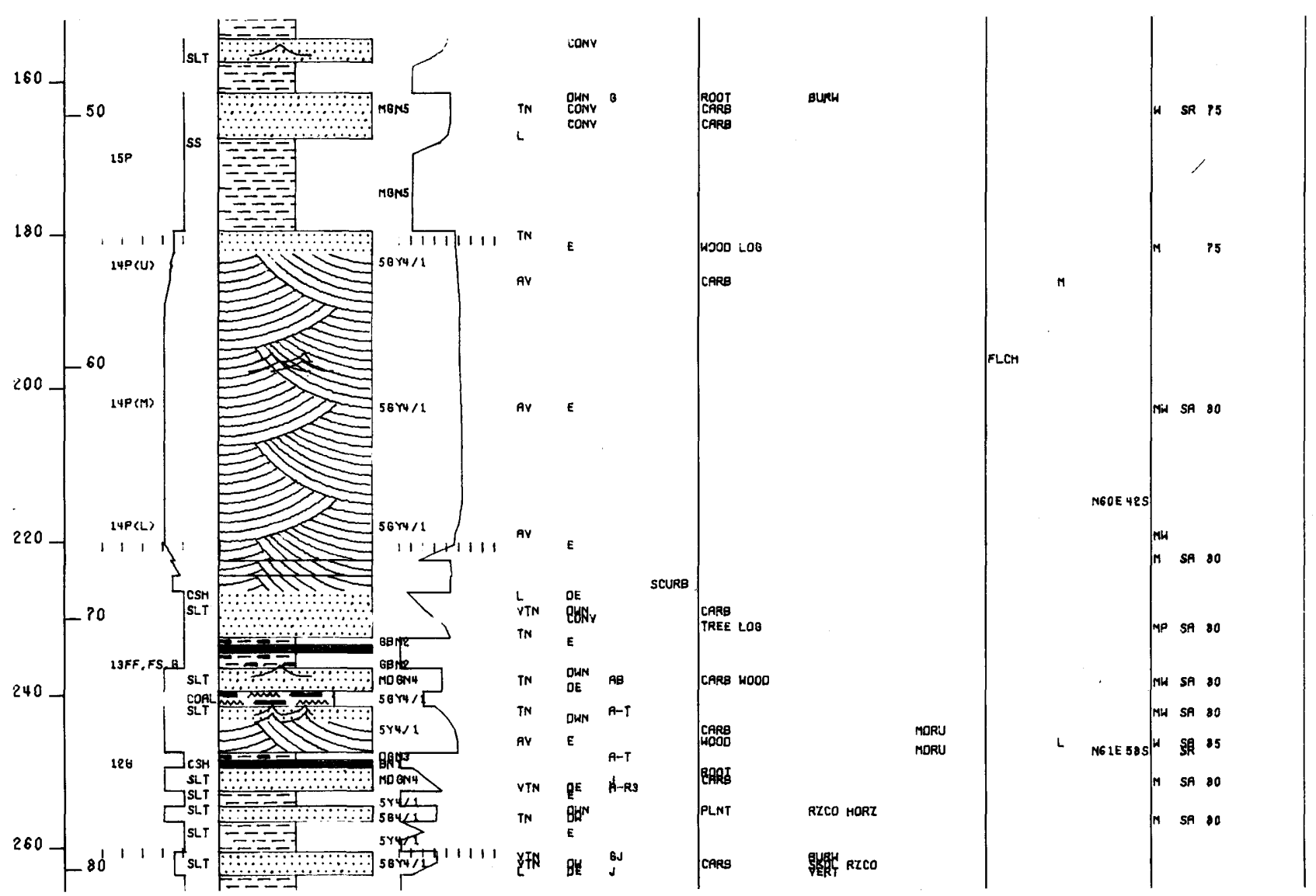

Appendix 1.--Example of a computer-drawn display of the Killik Bend measured section of the Nanushuk Group. (See fig. 1.) The measured section is treated as a well location, such that numbers on the left margin of the plot refer to depth below the top of the section. 


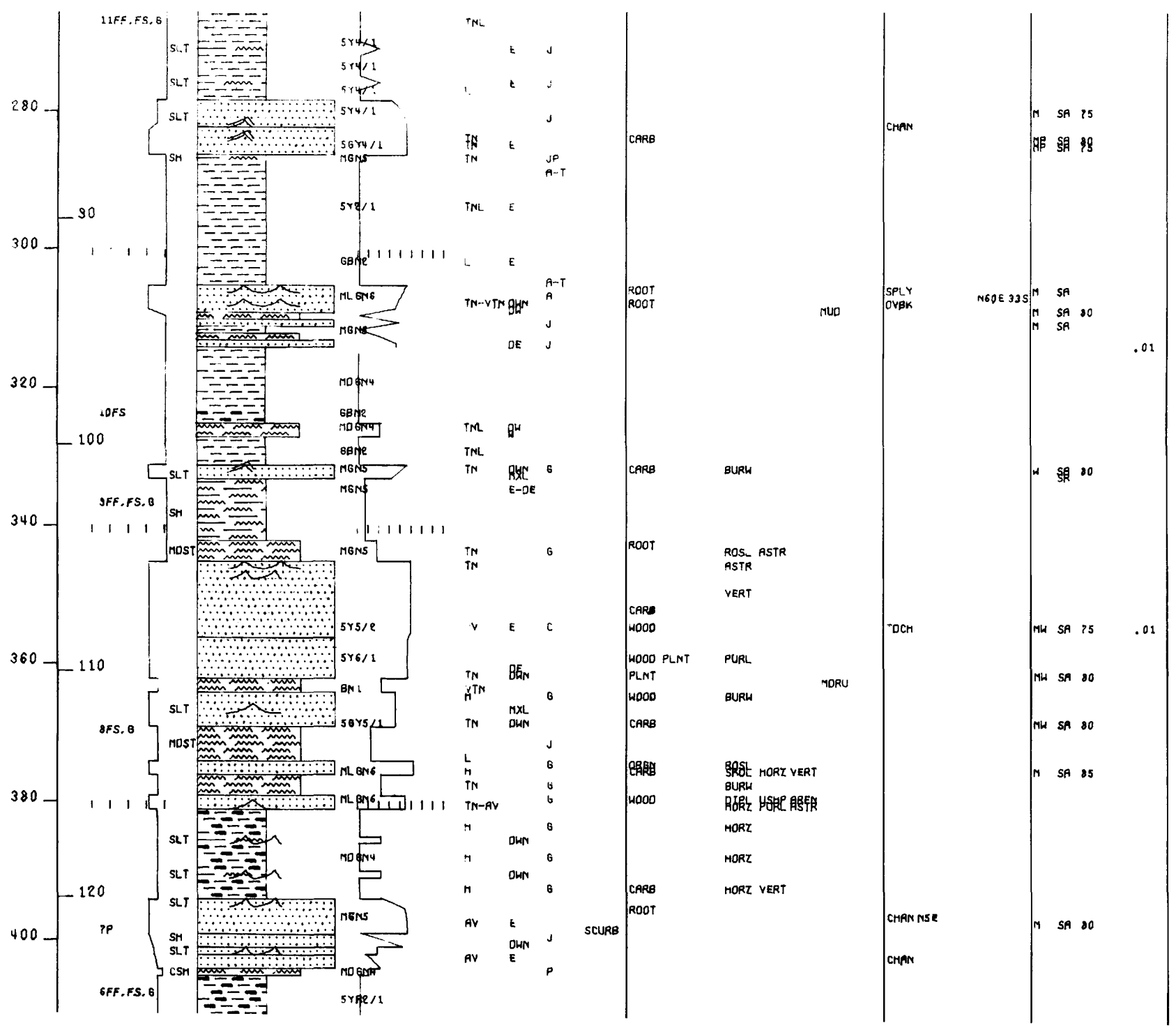




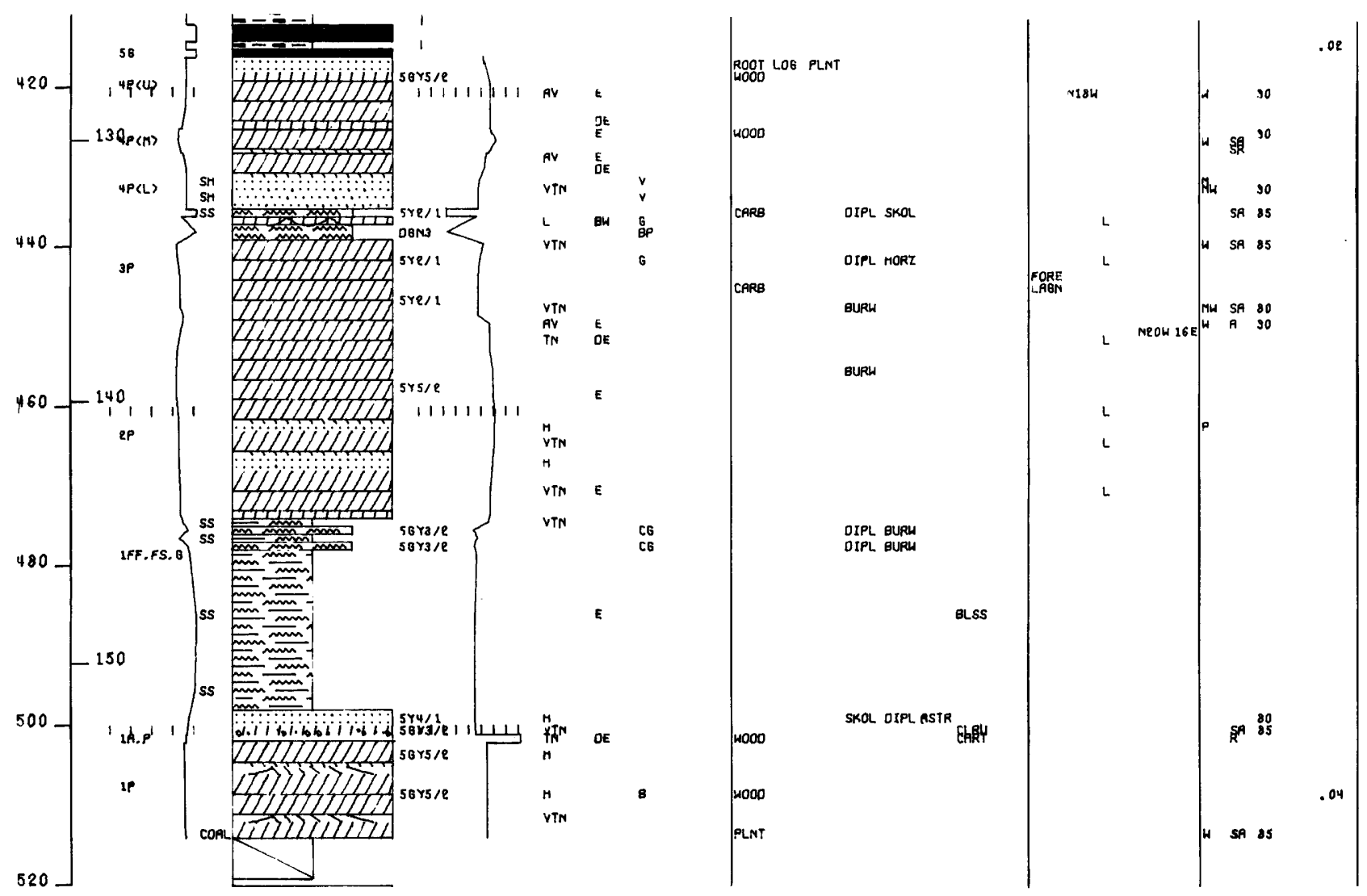

Appendix 1.--Example of a computer-drawn display of the Killik Bend measured section of the Nanushuk Group. (See fig. 1.) The measured section is treated as a well location, such that numbers on the left margin of the plot refer to depth below the top of the section.--Continued 
EXPLANATION OF SYMBOLS AND ABBREVIATIONS USED IN APPENDIX 1

[Abbrev, abbreviation. All abbreviations are found in a dictionary of terms used for these computer displays, which is available from Petroleum Information Corp., Denver, Colo.]

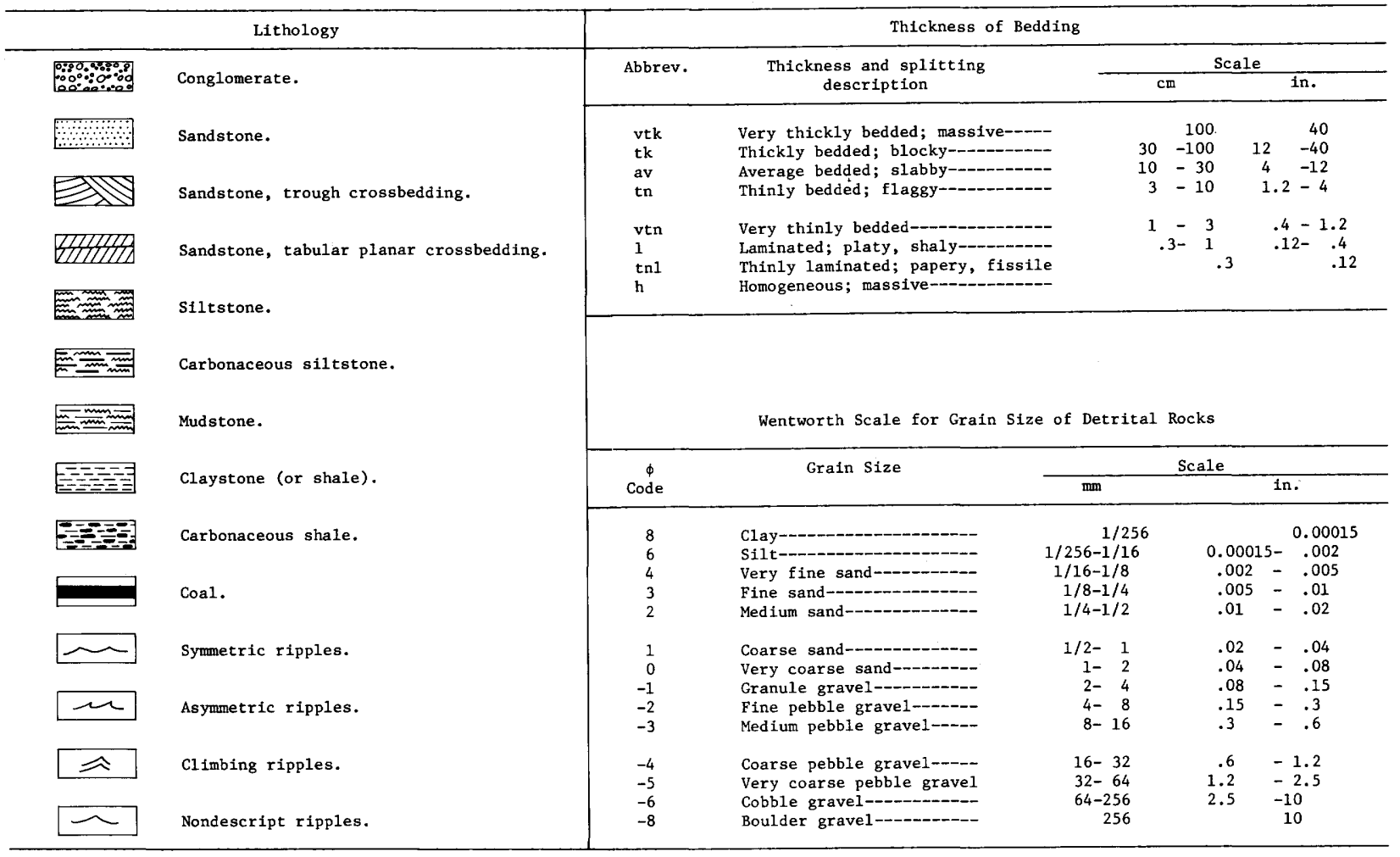

Abbreviations for Other Terms Used in Appendix 1

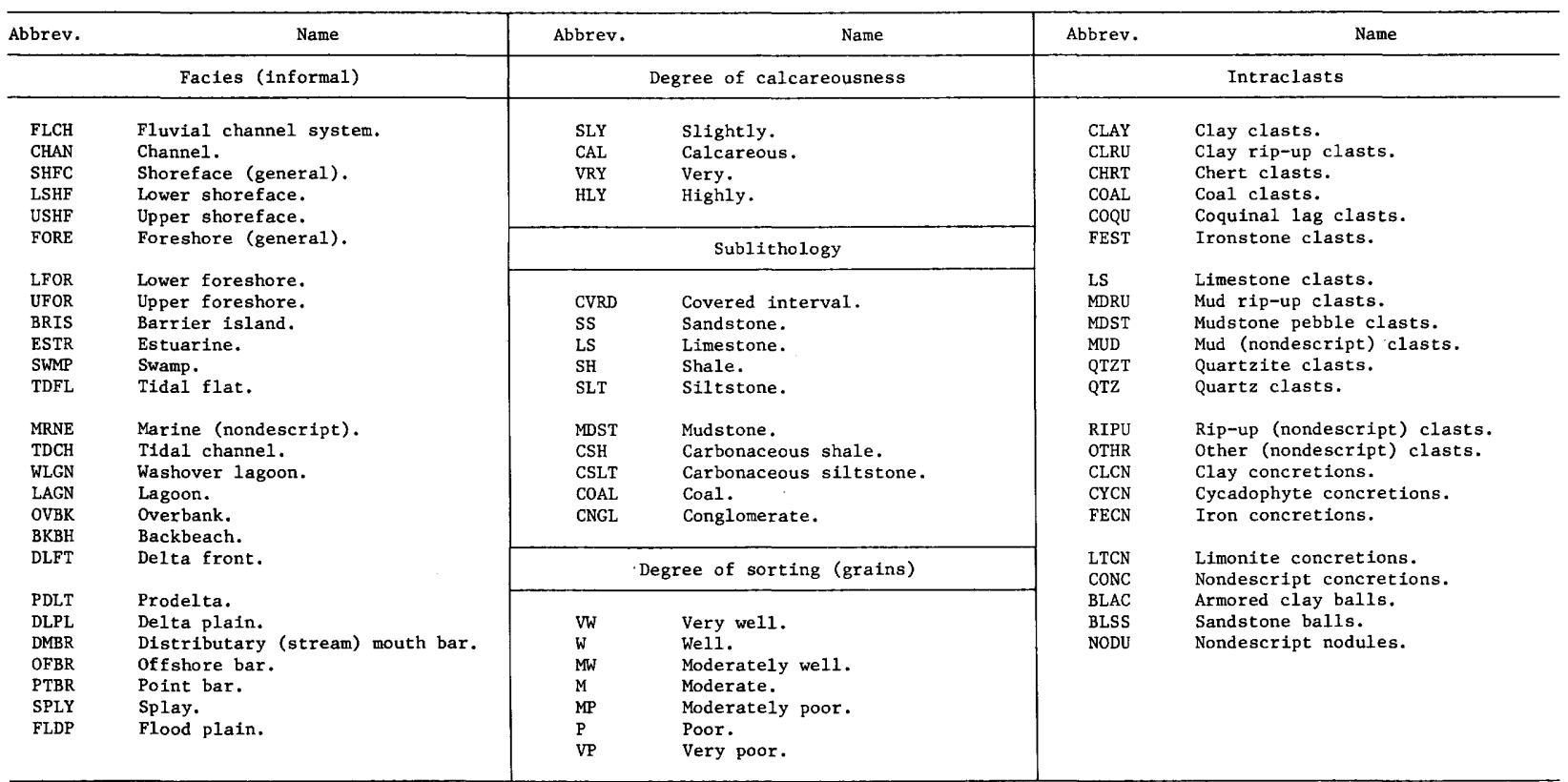


Abbrevlations for Other Terms Used in Appendix 1--Continued

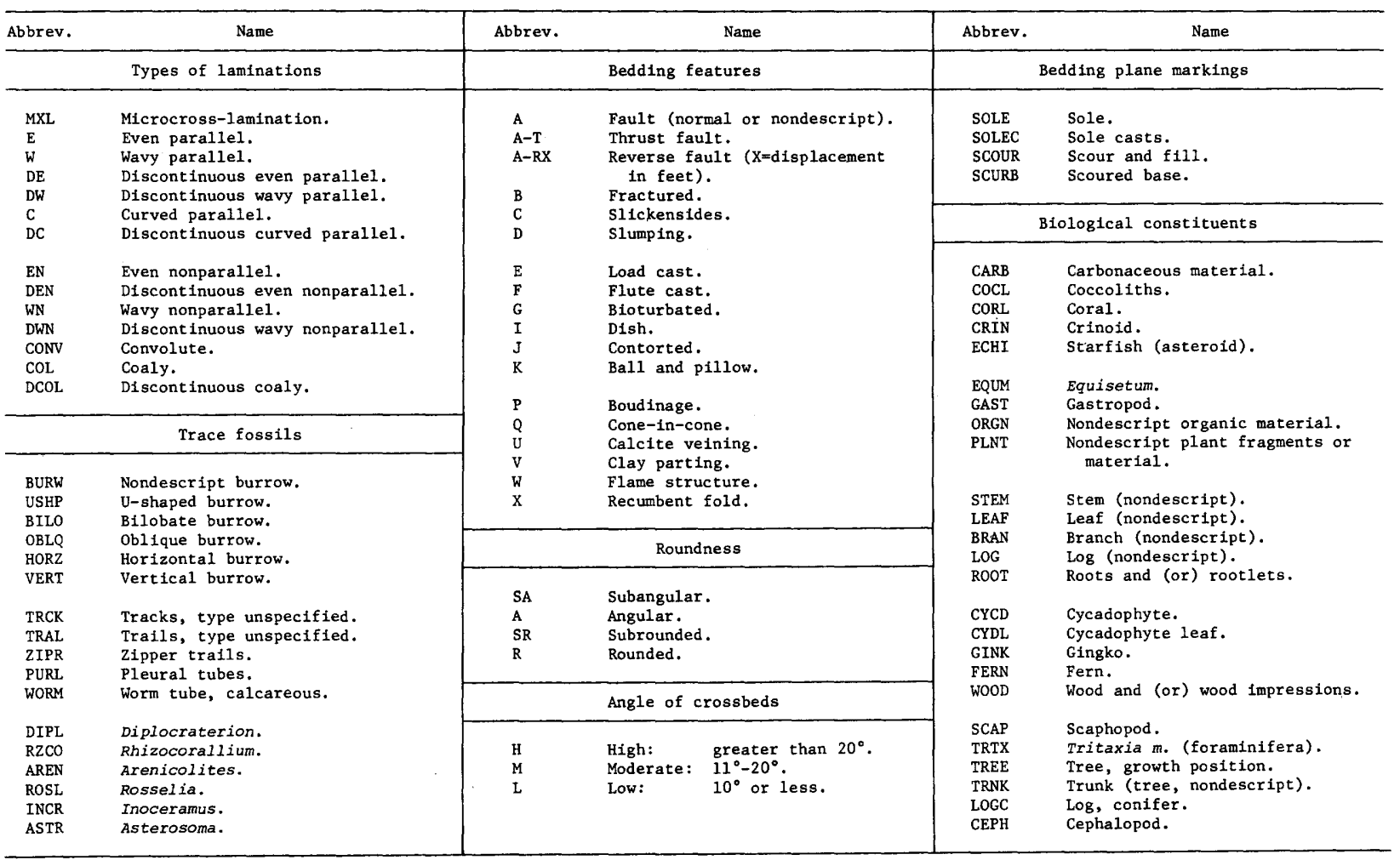




\section{SUBSURFACE STUDIES OF THE NANUSHUK GROUP, NORTH SLOPE, ALASKA}

By K. J. Bird and Jack Andrews ${ }^{1}$

\section{INTRODUCTION}

The objectives of this part of the Nanushuk study are to identify and map the more favorable reservoir trends in the subsurface Nanushuk Group. To achieve these objectives, we plan to relate the more porous intervals in the wells to environments of deposition as determined by the study of cores and logs, to tie these results to similar studies from outcrop, and eventually to relate this information to the seismic data. Additional porosity measurements are being made, and detailed sedimentologic studies of the cores are underway. These studies are being conducted by Ira Pasternak and $\mathrm{K}$. J. Bird.

The information presented here is based on a study of new seismic data and a network of correlated well logs. The seismic data, which have been obtained since 1974, consist of more than 10,000 line-kilometers of coverage on a grid approximately $10 \times 20 \mathrm{~km}$. Subsurface Nanushuk data points consist of 33 wells drilled during the U.S. Navy Pet-4 program (1945-53), about 14 wells drilled by private industry adjacent to the reserve, and 13 wells drilled within the reserve between 1974 and 1978. (See fig. 1 for locations.) Although all Nanushuk data points have been reviewed, only the most complete outcrop sections and well penetrations, providing the widest geographic coverage, have been selected for inclusion in figure 10 and table 2 .

\section{STRATIGRAPHY}

From the Nanushuk Series, the Nanushuk Group was redefined by Gryc, Patton, and Payne (1951, p. 162) as a section of rock composed of sandstone, shale, conglomerate, and coal exposed along the Nanushuk River south of Umiat (fig. 10). These rocks have been studied in the western and central North Slope in outcrop by Chapman and Sable (1960), Detterman, Bickel, and Gryc (1963), Chapman, Detterman, and Mangus (1964), Patton and Tailleur (1964), and Brosgé

I Tetra Tech, Inc., Houston, Tex. and Whittington (1966) and in the subsurface by Collins and Robinson (1967). The complex stratigraphic nomenclature that resulted from these numerous studies and some of the uncertainties in correlating these units are summarized in figure 5. Pending further study and better correlation of these rocks, we have used the general stratigraphic terminology of Colville Group, Nanushuk Group, and Torok Formation (instead of the Topagoruk and Oumalik Formations). An additional rock unit not shown in figure 5, but of great importance as a key correlation horizon in the subsurface, is the Lower Cretaceous (Neocomian) "pebble shale" unit (Alaska Geological Society Newsletter, 1978). This informal rock unit, which overlies a regional unconformity and forms the surface over which the Torok Formation prograded, derives its name from well-rounded quartz sand grains and occasional chert granules scattered through a dark-gray clay-shale matrix. It is a distinct stratigraphic unit generally 100-200 $m$ thick that is easily correlated over long distances by means of 1ithology, well logs, and seismic records.

Earlier studies clearly demonstrated that the Nanushuk Group forms a northward-prograding clastic wedge of Early and Late Cretaceous age that is overlain and underlain by marine shale (Gryc and others, 1951; Payne and others, 1952). Seismic data showed north to northeast dips in the Cretaceous rocks, which are overlain and underlain by essentially flat-1ying beds. Core data from wells confirmed the seismic dips and indicated that the dips are in the finegrained marine sediments (Torok Formation) below the Nanushuk. The Torok Formation and the Nanushuk Group were considered to be distinct and separate rock units representing "orogenic" and "post-orogenic" deposition, respectively (Payne and others, 1952). New seismic and closely associated well data (fig. 11) reveal important stratigraphic relationships apparently not clearly shown in the earlier data. The most important feature of these new seismic data is the continuity of some reflectors from topset to foreset to bottomset positions, or from undaform to clino- 


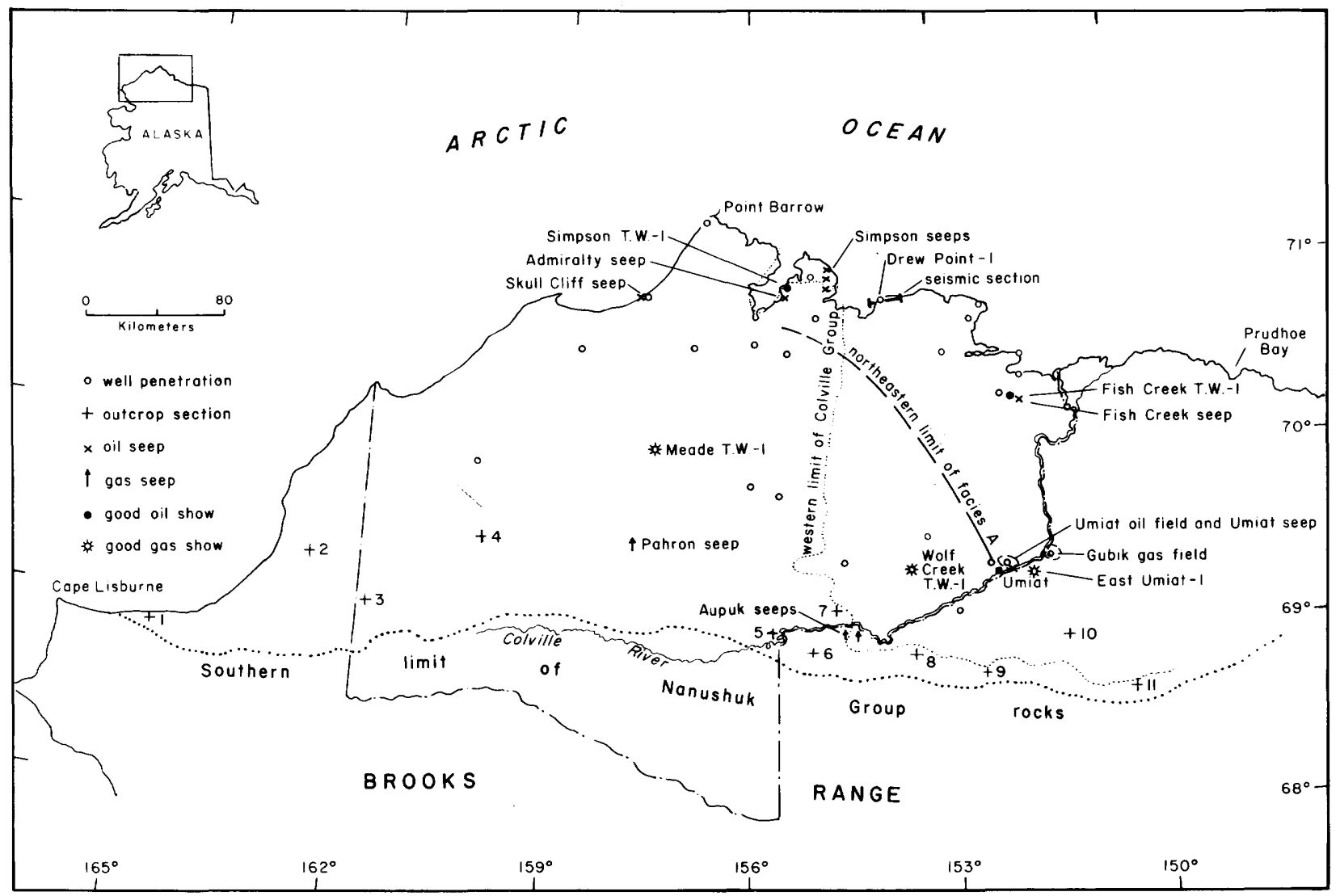

Figure 10.--Index map of a part of the North Slope of Alaska showing selected Nanushuk Group data points, hydrocarbon locations, and the major facies boundary. Numbered points refer to outcrop localities shown in table 2. Erosional remnants of the Colville Group (not shown on map) may be present locally in western NPRA, as reported by Chapman and Sable (1960) and Smiley $(1966,1969 b)$.

form to fondoform in the terminology of Rich (1951). On seismic sections longer than that shown in figure 11, an individual reflection within the Nanushuk can be traced basinward and observed to lie progressively lower in the group (because of loss of section from the base by progradation) until it passes from Nanushuk into topset, foreset, and bottomset Torok. Each continuous reflector is regarded as a time line following paleotopography at some instant in geologic time. These new data indicate that the Nanushuk Group and Torok Formation are lateral equivalents representing a single depositional system. The topset seismic reflectors include alluvial-deltaic and shelf deposits of the Nanushuk Group and upper part of the Torok Formation; foreset reflectors consist of slope deposits of the middle part of the Torok Formation; and the bottomset reflectors consist of basin-floor deposits of the lower part of the Torok Formation. The distinction between "orogenic" and "post-orogenic," therefore, does not apply to this situation.

Some foreset reflections in figure 11 show truncation by topset reflections, demonstrating a "toplap" relationship (Mitchum, 1977) that probably represents a temporary hiatus resulting from bypassing of sediment. It was probably a toplap relationship that Collins and Robinson (1967, p. 50) regarded as an angular unconformity marking the contact between the Oumalik and Topagoruk Formations (fig. 5).

In contrast to other areas of deltaic sedimentation such as the Mackenzie delta or the Mississippi delta, no growth faults or diapirs have been observed on the seismic records. Irregular, discontinuous, and sometimes truncated reflections in the foreset interval do suggest considerable sediment instability and mass movement.

The new data also elucidate important regional stratigraphic relationships of the Cretaceous rocks. Seismic sections near the eastern edge of NPRA (National Petroleum Reserve in Alaska) show a much reduced thickness of Nanushuk Group and the beginning of lowamplitude foreset structures in the overlying Colville Group. These data appear to show the termination of Nanushuk progradation by a relative rise in sea level, westward transgres- 


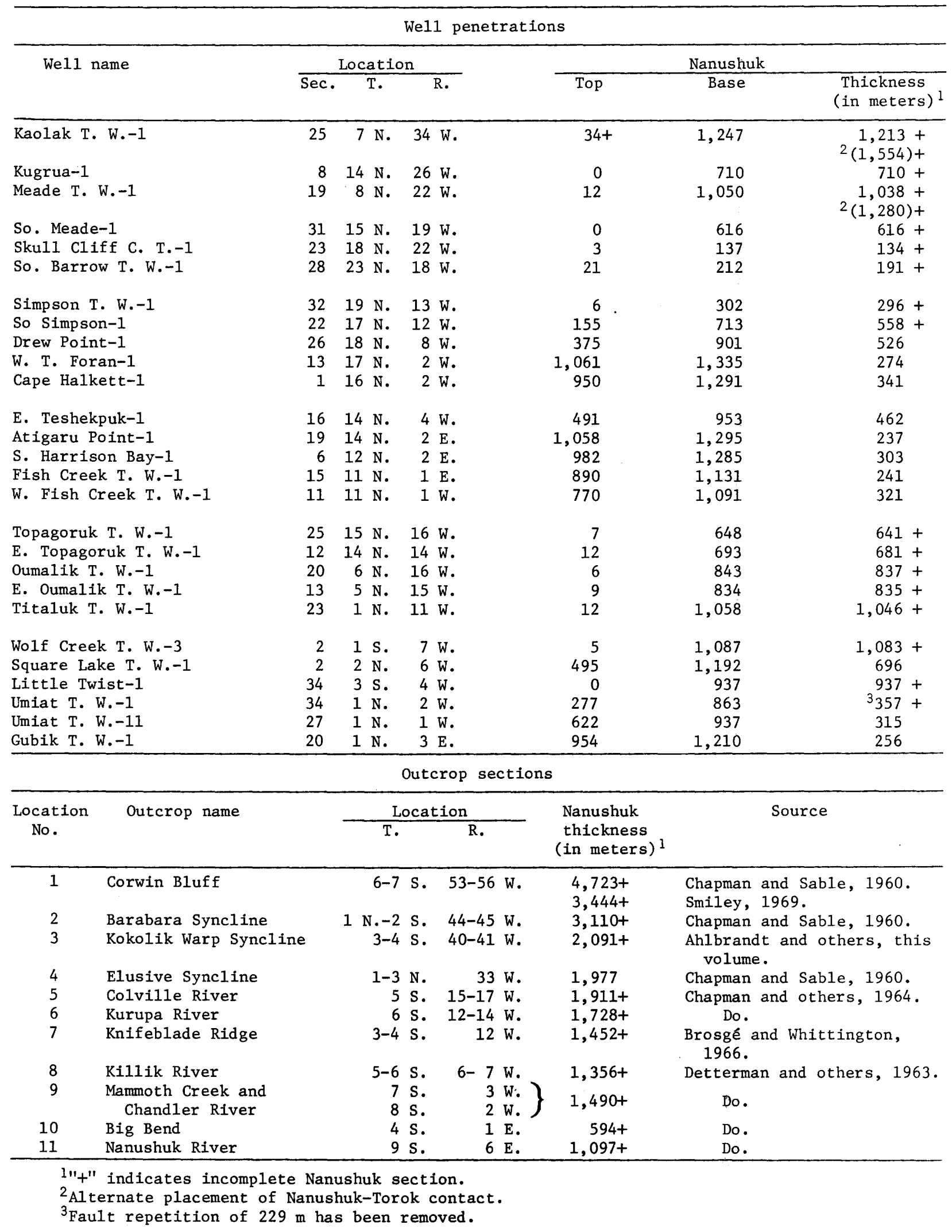




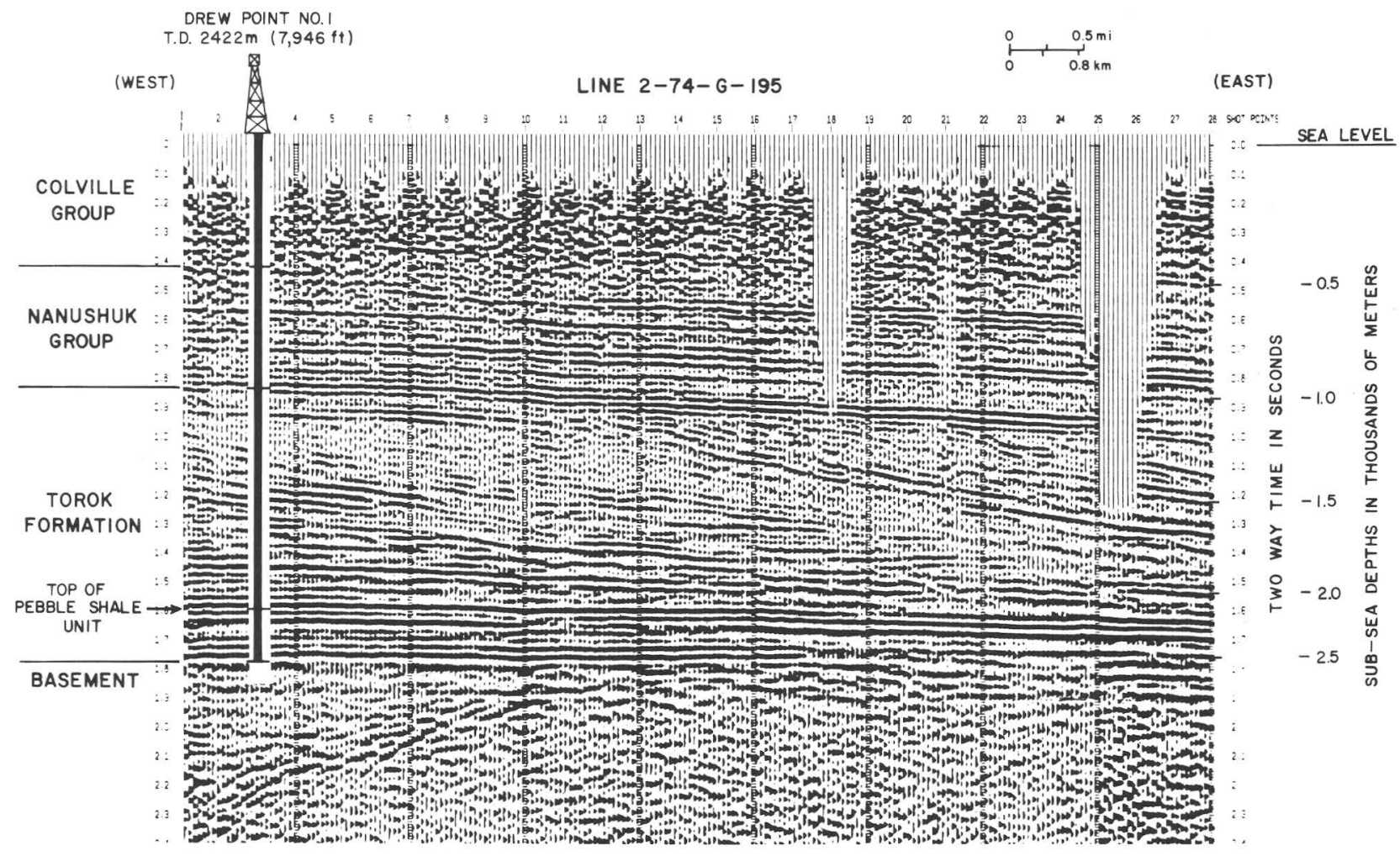

Figure 11.--Seismic section passing through the Drew Point-1 well location. (See fig. 10 for location.) Stratigraphy has been keyed to the seismic section using a synthetic seismogram from the well. Note the characteristic topset (undaform), foreset (clinoform), and bottomset (fondoform) reflections and their relationship to the stratigraphy. See figure 14 for details of stratigraphy and log response.

sion of the shoreline in earliest Colville time, and subsequent eastward progradation by the Colville Group in a style similar to that of the Nanushuk Group. When these relationships are extended eastward beyond the area of seismic coverage by correlated well logs, the Nanushuk Group and Torok Formation are not found in the Prudhoe Bay area; their absence may be explained by pinch-out to very thin "distal" bottomset beds (fig. 12). This explanation eliminates the need for postulating an unconformity cutout of the Nanushuk Group and most of the Torok Formation in the Prudhoe Bay area (North Slope Stratigraphic Commission, 1971). By incorporating available paleontologic information, these data have been converted to a simplified timestratigraphic chart (fig. 13). Note that in this interpretation, the Aptian Stage, long considered missing and a period of erosion in almost all of Alaska, is represented by relatively deep marine shale. A deep marine environment, possibly below the calcite compensation depth and possibly low in oxygen, may help to explain the near absence of diagnostic Aptian fossils.
Optimum use of the seismic data requires accurate matching of the stratigraphy to the seismic records. In the newer wells, the seismic data can be more accurately related to the stratigraphy using synthetic seismograms and velocity surveys. Details of the stratigraphy, log response, and structural attitudes are shown in relation to the seismic features for the Drew Point well in figure 14. Note the correspondence of the core dips and dipmeter data to the seismic features. The foreset interval, characterized by a monotonous $10 \mathrm{~g}$ response, consists predominantly of shale with rare sandstone and siltstone. In contrast the bottomset interval, having slightly more log character, consists of more siltstone and sandstone than the foreset interval. It is noteworthy that the bottomset beds lie in the same stratigraphic position as the Fortress Mountain Formation relative to the Torok Formation in outcrop (fig. 5), suggesting that some of the Fortress Mountain Formation may represent bottomset deposition.

By recognizing the significance of the foreset structures, the directions of prograda- 


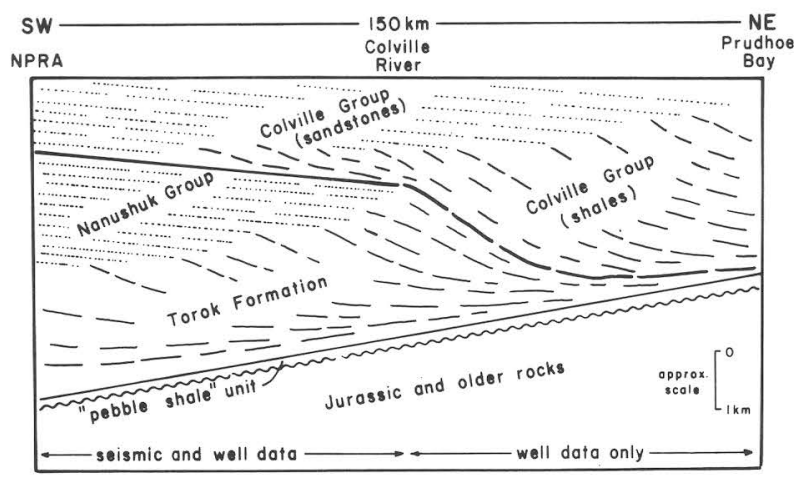

Figure 12.--Diagrammatic section based on seismic and correlated well data showing Cretaceous stratigraphic relations between the rocks of NPRA and Prudhoe Bay. Termination of the Nanushuk-Torok wedge was caused by the Colville Group transgression, which was followed by renewed progradation in a style similar to that in the underlying rocks.

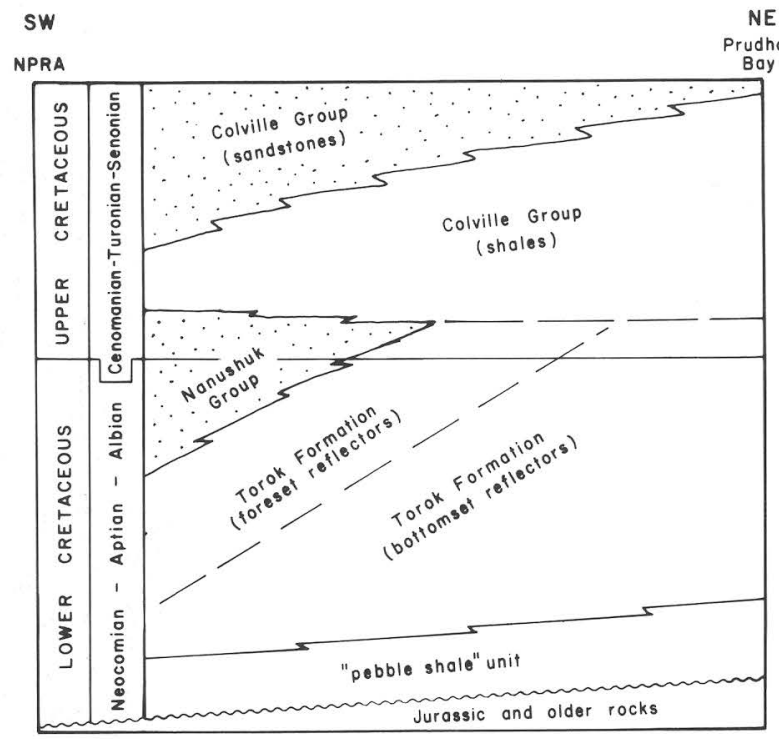

Figure 13.--Diagrammatic Cretaceous timestratigraphic chart for northern NPRA based on available paleontologic data and the relationships shown in figure 12 . Note that the entire Cretaceous section can be explained in terms of continuous sedimentation from "pebble shale" unit through Colville Group without regional erosional hiatus. Diagram does not apply to foothills outcrop belt.

tion, shoreline trends, and basin filling may be estimated. Andrews measured apparent foreset dip at seismic-1ine intersections and calculated resultant true-dip vectors. These vectors are shown in figure 15 along with dipmeter data from Nanushuk Group sandstones, direction of maximum shale-out of Nanushuk Group sandstones from outcrop (Chapman and Sable, 1960, p. 95), and Nanushuk paleotransport data collected by Ahlbrandt and others. Note the apparent shift in directional indicators from northeast to east in the southwest to the northeast parts of the reserve. The sparsity of foreset dip vectors in the southwest half of the reserve is partly a reflection of fewer seismic data and fewer identifiable foreset structures. The remarkable consistency of these data suggest that the basin filled initially in a northeast direction and later in a more easterly direction. Shoreline trends are assumed to have been approximately perpendicular to the direction of progradation.

\section{NANUSHUK LOG CHARACTERISTICS}

The electric log character of the Nanushuk Group shows a systematic change from west to east. Three widely spaced wells have been selected to illustrate this change (fig. 16).

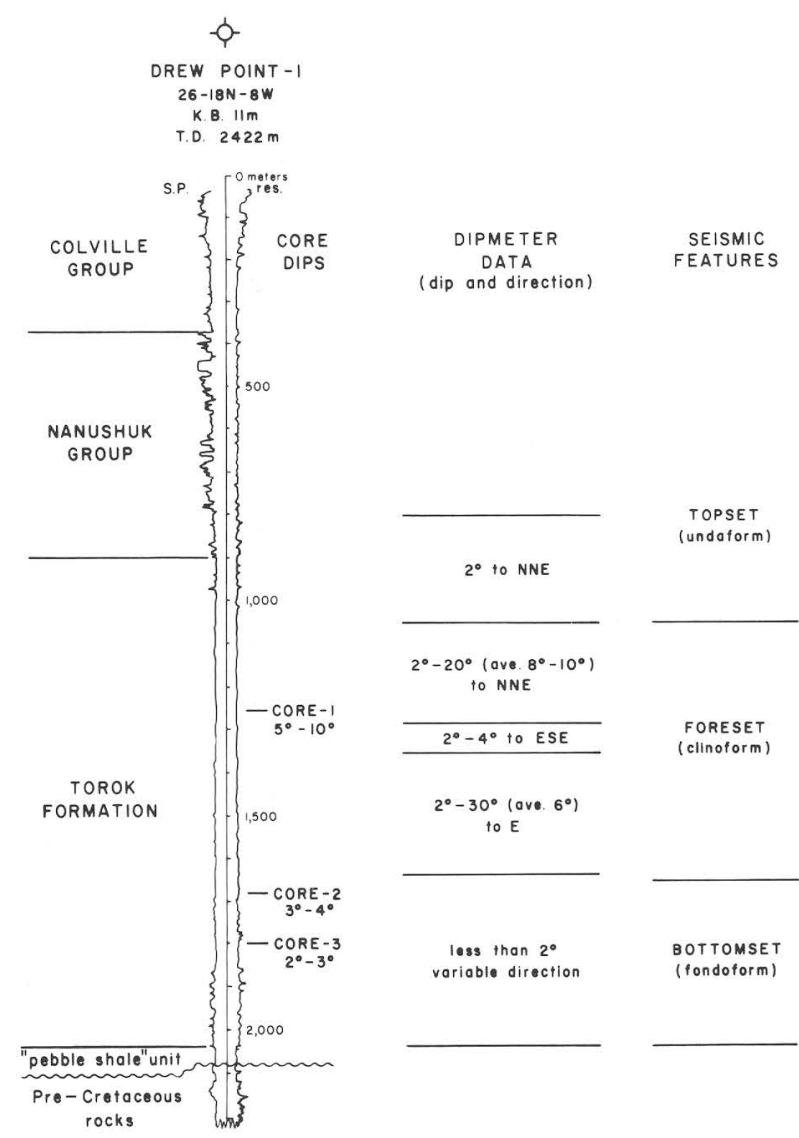

Figure 14.--Cretaceous section in the Drew Point-1 well showing the relationship of stratigraphy to $\log$ response, structural attitudes, and seismic data. 


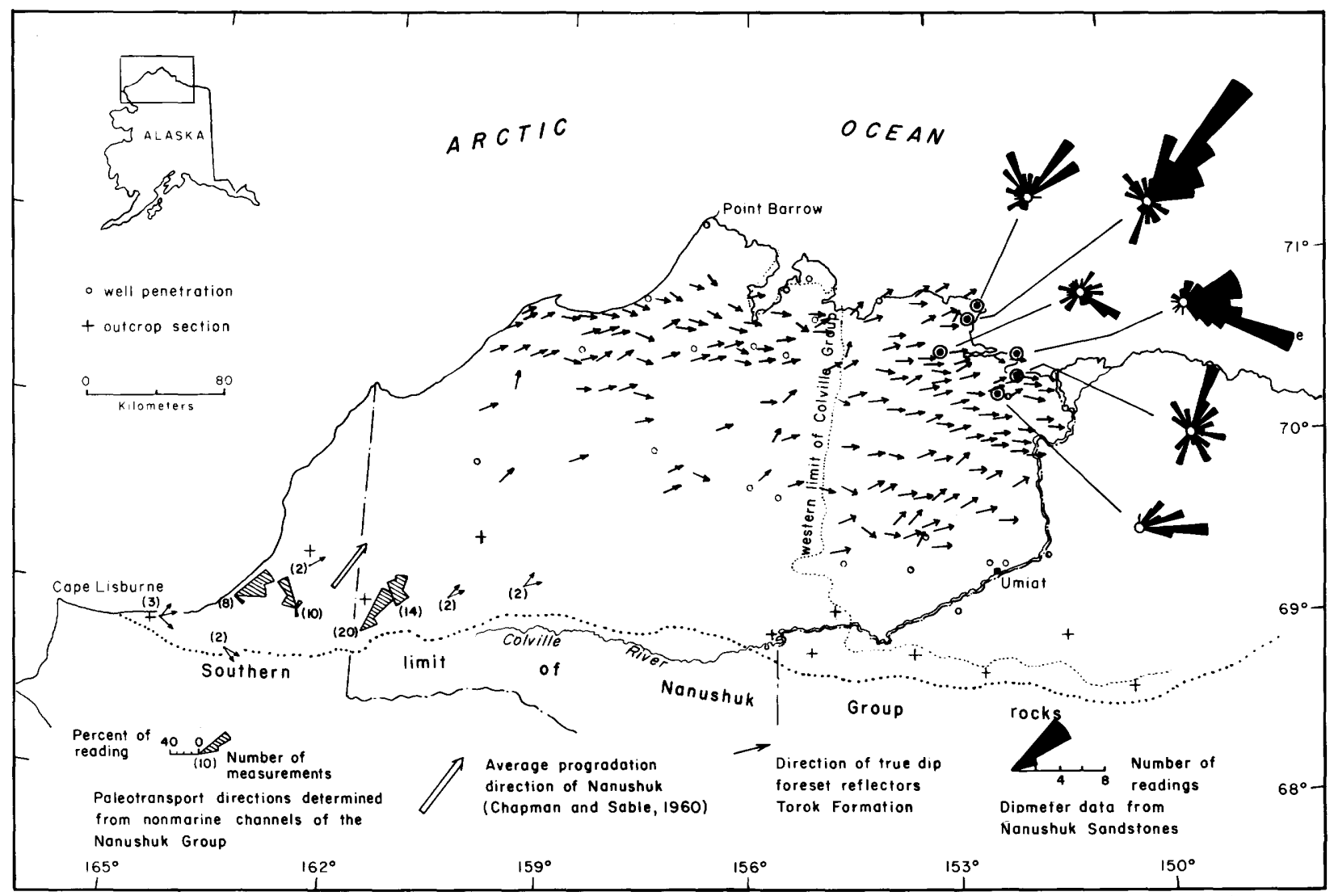

Figure 15.--Plot of directional data from seismic foreset dips in Torok Formation, dipmeter data from Nanushuk Group sandstones, direction of Nanushuk progradation from outcrop (Chapman and Sable, 1960), and direction of plunge of symmetrically filled nonmarine channels of the Nanushuk Group as measured by Ahlbrandt and others (this volume).

The westernmost well (Kaolak T. W.-1) is characterized by relatively thin sandstones scattered through a predominantly coaly shale section. There is no distinct Nanushuk-Torok contact in this well; it is placed arbitrarily at the base of the lowest significant sandstone bed. To the east (Titaluk T. W.-1), the lower part of the Nanushuk consists of numerous thick sandstone beds separated by shale and siltstone beds of approximately equal thickness, and the upper part of the Nanushuk consists of thinbedded sandstones in a predominantly coaly shale section similar to the section in Kaolak. The Nanushuk in the easternmost well (Fish Creek T. W. -1) consists of sandstone and shale of roughly equal proportion; it is similar to the lower part of the Titaluk well, although the section is very thin owing to a position near the pinch-out of the Nanushuk wedge.

The coaly shale interval is herein designated facies $A$ and the section having more abundant sandstone, facies $B$. Although future core study is expected to provide a more detailed environmental interpretation, gross lithologic character and stratigraphic position suggest that facies A corresponds to the non- marine and transitional environment and that facies $B$ corresponds to the marine environment of Ahlbrandt and others (fig. 6).

Recognition of these two facies is thought to be important to hydrocarbon exploration, because the sandstone beds of facies $B$ grade laterally and pinch out into facies $A$, forming potential stratigraphic traps. The easternmost extent of facies $A$ is shown in figure 10.

Stratigraphic traps of this type are expected only to the west of this line. It is interesting to note that Umiat oil field lies along this boundary. Perhaps the Umiat oil was first stratigraphically trapped and later focused by the development of Umiat Anticline.

\section{HYDROCARBON OCCURRENCES}

Hydrocarbon occurrences in the Nanushuk Group (fig. 10) consist of the Umiat oil field and the Gubik gas field. Significant but subcommercial discoveries of gas have been made in East Umiat-1, Meade T. W. -1 , and Wolf Creek T. W. -3 and of oil, in the Simpson T. W. -1 and Fish Creek T. W. -1 . Lesser oil and gas shows are common throughout the Torok Formation and 


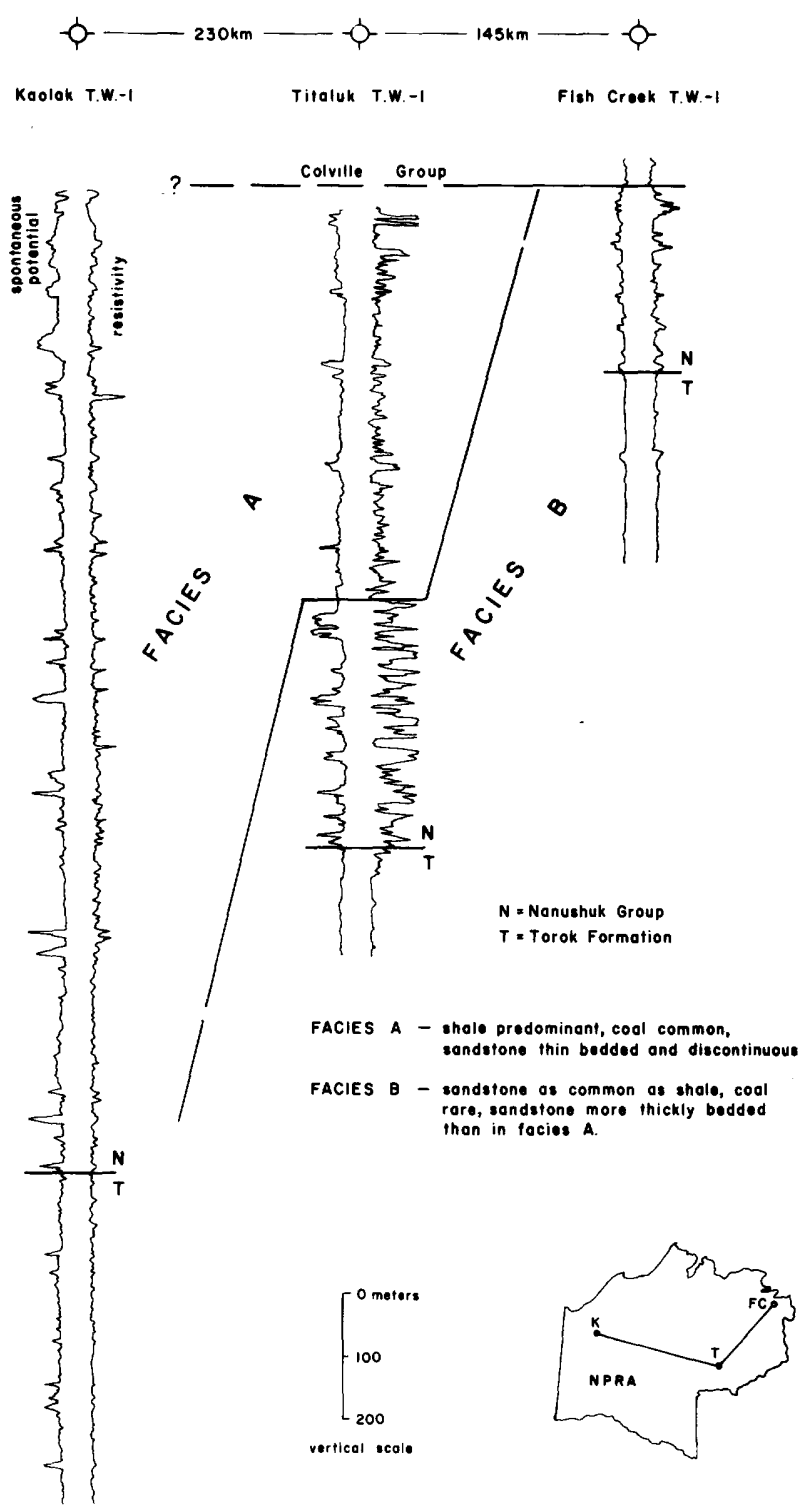

Figure 16.--Log response and gross lithofacies subdivision in three wells spanning NPRA.

Nanushuk Group. Surface seeps of oil and gas are fairly numerous and are located in figure 10 .

\section{ISOPACH MAPS}

In recognition of the close genetic relationship of the Nanushuk Group and Torok Formation, isopach maps have been constructed showing their combined thicknesses (fig. 17) and the thickness of each unit individually (figs. 18 and 19). All three maps show a similar pattern of northward thinning. The isopachs trend west to northwest in the southwest portion of the reserve, whereas in the northeast part of the reserve they show a marked deflection to the north. Comparison of isopach trends with paleotransport directions (fig. 15) shows that these two trends are generally perpendicular, except in the area about Point Barrow which has undergone significant erosion. The effect of post-Nanushuk erosion on isopach trends would be a shifting of them to the south as at Point Barrow. However, in areas far to the south of Point Barrow, the similarity of isopach trends (fig. 18) in areas that have no Nanushuk erosion (between Umiat and the edge of the Colville Group) and in areas where Nanushuk has been eroded (west of the edge of the Colville Group) suggests that the amount of erosion.may be relatively insignificant.

The trend of isopachs on all three maps is oblique to that of the present-day Brooks Range. Perhaps the isopachs reflect the trend of the Nanushuk source terrane. The source terrane may have paralleled the Herald Arch, the extension of the Brooks Range orogen northwesterly from Cape Lisburne (Grantz and others, 1976, fig. 3), but it may diverge from the Brooks Range trend east of Cape Lisburne. The maximum thickness of the Nanushuk Group and the Torok Formation in the Cape Lisburne region suggests a combination of greater uplift in the source area and subsidence of the basin. Northeastward progradation is envisioned to have continued until the basin was prograded to about the position of the 900-m Nanushuk isopach (fig. 18). At this time the shift in direction of progradation from northeast to more nearly due east may have been accomplished by gentle eastward tilting of the basin. Slight uplift in the west and depression in the east may have produced a north-trending shoreline over the slightly submerged Barrow Arch, whereas to the south, where water depths were probably greater, tilting of the basin would not have immediately affected the direction of progradation.

\section{SUMMARY}

New seismic and well data in NPRA reveal that the Torok Formation and Nanushuk Group constitute a single prograding depositional system consisting of topset, foreset, and bottomset beds. The direction of progradation as indicated by seismic, dipmeter, and outcrop data was initially to the northeast and later nearly due east.

Review of the subsurface data suggests several hydrocarbon plays in the Torok Formation and Nanushuk Group. These include (1) anticlinal traps in the fold belt, (2) structura1stratigraphic traps formed by updip shaling-out of basal sandstones of the Nanushuk on the south flanks of anticlines, (3) structuralstratigraphic traps formed by shaling-out of marine sandstones of the Nanushuk updip into transitional and nonmarine shales of the Nanushuk, and (4) stratigraphic traps in the Torok Formation formed by sandstones on the depositional slope being sealed by surrounding shales. 


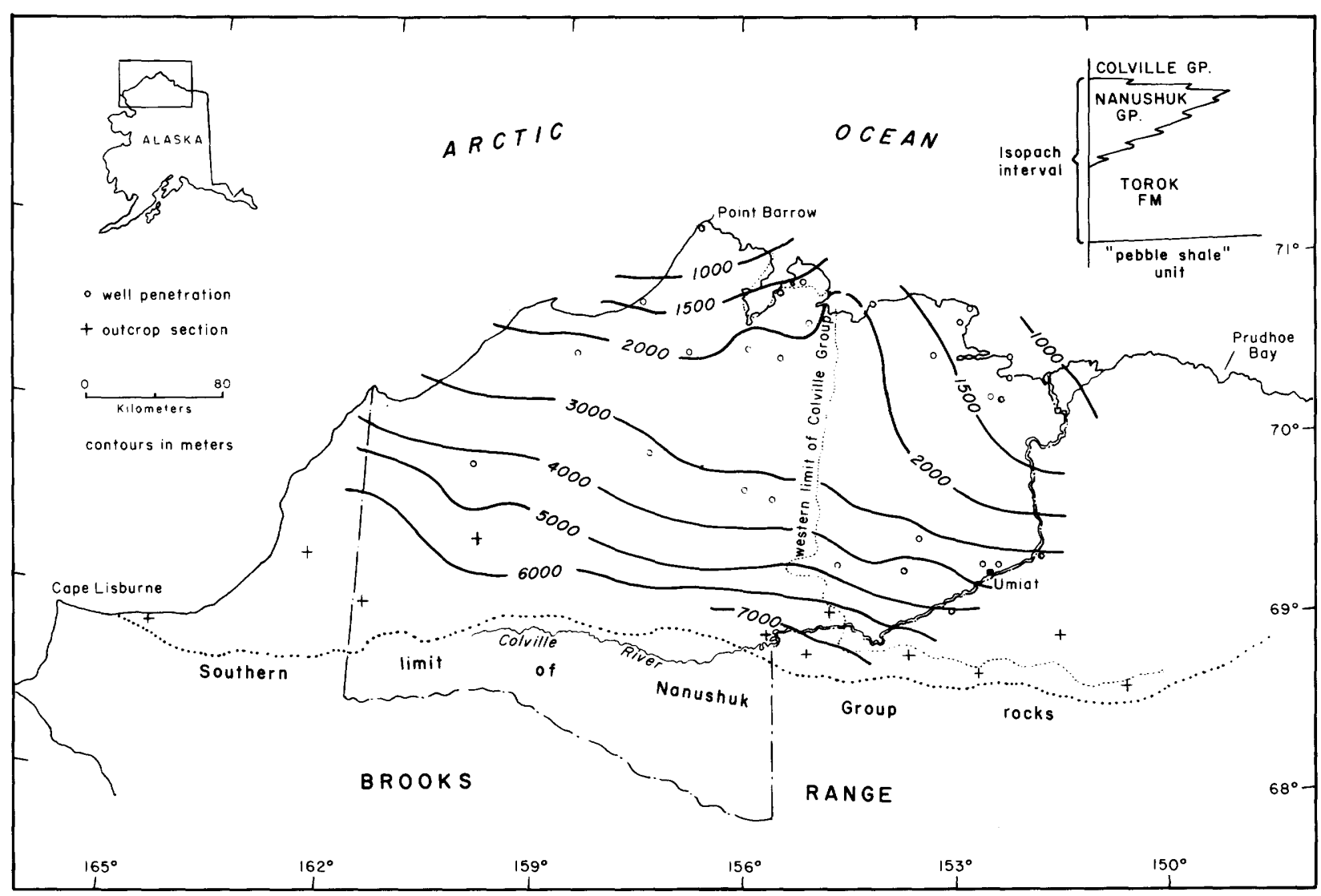

Figure 17.--Isopach map showing the combined thicknesses of the Torok Formation and the Nanushuk Group utilizing the structure contour map on the basal Cretaceous horizon (J. Harris and C. C. Miller, unpub. mapping, 1977). Structural complexity associated with Brooks Range front prevents extension of the contours farther south. 


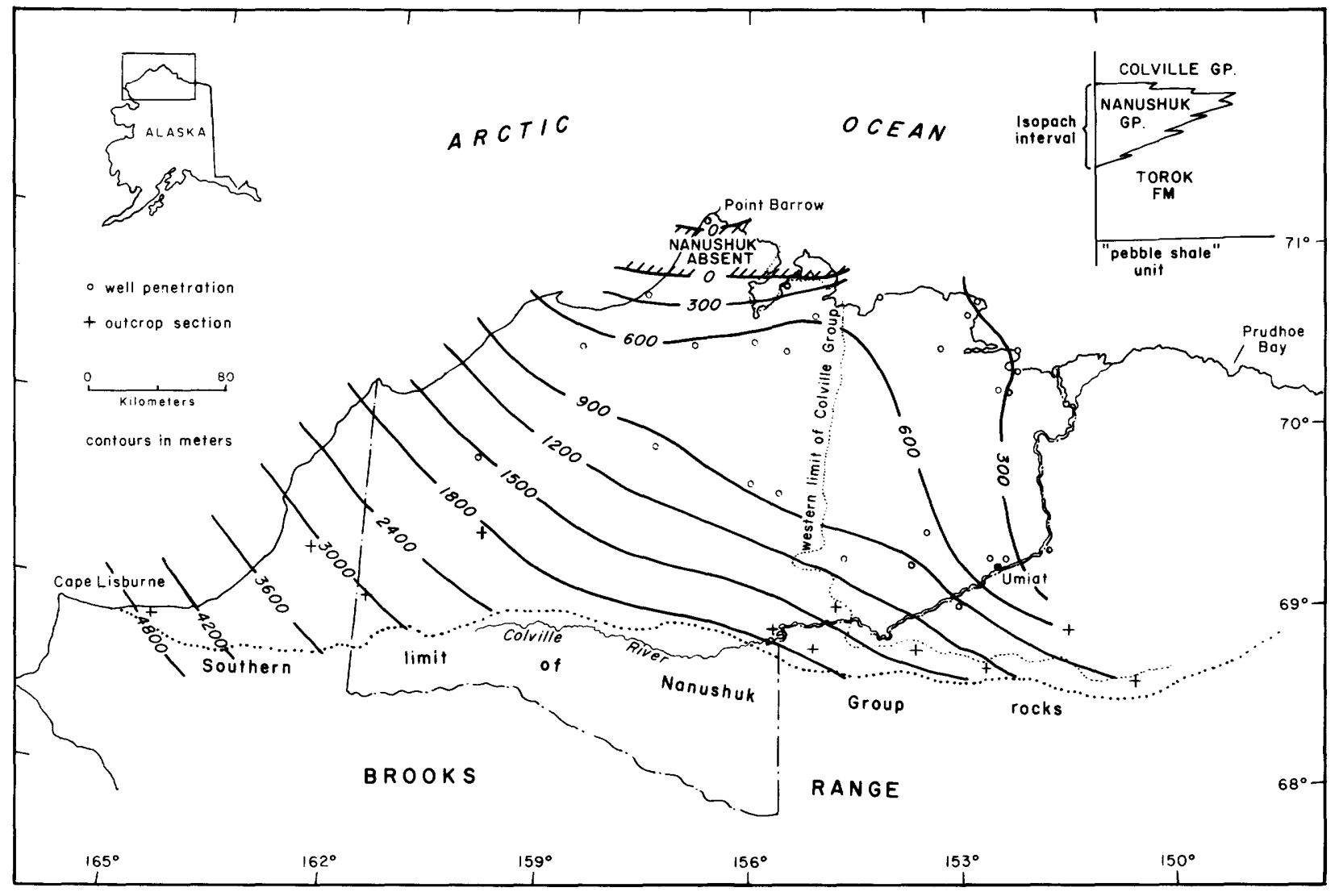

Figure 18.--Nanushuk Group isopach map based on selected we11 and outcrop sections. Numbers refer to outcrop localities shown in table 2. Note the general northwesterly isopach trend for much of the area and the pronounced shift in the trend in the northeastern corner of the reserve. 


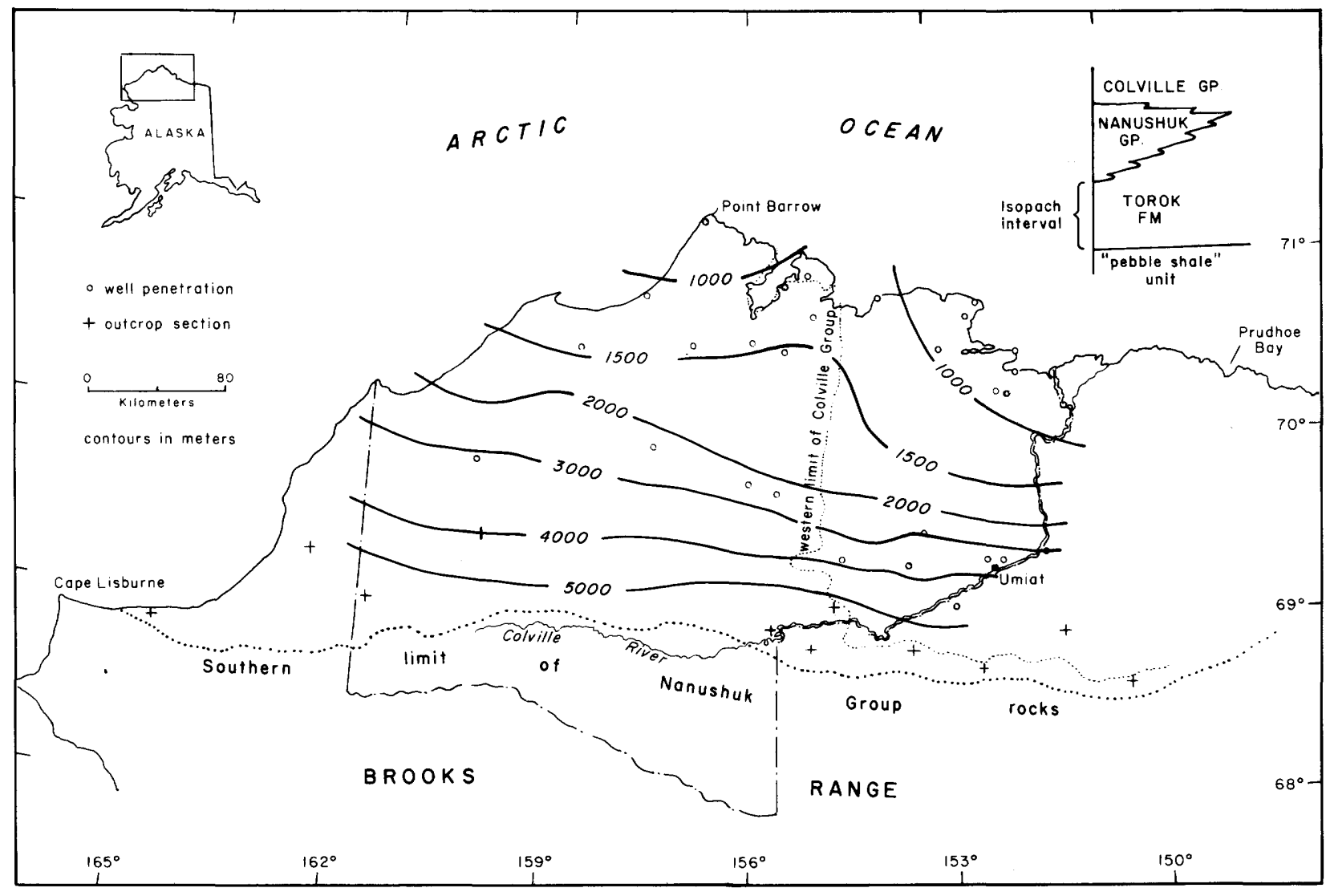

Figure 19.--Torok Formation isopach map, which was constructed by plotting the difference between contour values shown on figures 17 and 18 . Note the similarity in trends to those of the previous maps. 
A SUMMARY OF RESERVOIR CHARACTERISTICS

OF THE NANUSHUK GROUP, UMIAT TEST WELL 11, NATIONAL PETROLEUM RESERVE IN ALASKA

By James E. Fox

\section{INTRODUCTION}

Umiat Anticline has the largest discovered hydrocarbon reserves in Cretaceous rocks of NPRA (National Petroleum Reserve in Alaska). The anticline is an east-west-trending structure located near the southeastern edge of NPRA, just north of the Colville River (fig. 20), and the primary production is from the Grandstand Formation of the Nanushuk Group. From 1945 through 1952, the U.S. Navy drilled and tested 11 wells on this anticline. The results of this work are discussed by Collins (1958a). Fox and others (1979) analyzed logs and studied the sedimentology, petrography, and paleontology of selected Lower and Upper Cretaceous sandstone units cored in Umiat test well 11. Test wel1 11 was selected because cores from it had the most complete unfaulted sequence of any of the Umiat wells (fig. 20). The purpose of the study was to identify the influence on porosity and permeability of sedimentologic factors such as character of sediment source rocks and depositional processes, as well as burial and diagenesis. Study of these factors has led to a better understanding of the potential of these units as hydrocarbon reservoirs. A summary of the part of the study dealing with Lower Cretaceous strata is presented here for comparison of these rocks in the central North Slope basin (eastern NPRA) with contemporary rocks in the western NPRA region, as presented in reports in this Circular. This summary will specifically discuss the Grandstand Formation, Killik Tongue of the Chandler Formation, and Ninuluk Formation, all of the Nanushuk Group. The cored intervals summarized in this chapter include the following (fig. 21):

Core 60 (911-916 m), Grandstand Formation; Cores 56-58 (865-869 m), Grandstand Formation;

Cores 52-53 (745-750 m), Grandstand Formation;

Core 49 (724-729 m), Killik Tongue of Chandler Formation; and

Cores 35-38 (624-639 m), Ninuluk Formation.

The stratigraphic terminology of Lower
Cretaceous rocks in the central North Slope basin (eastern NPRA) is shown, and it can be compared to that used for the western NPRA (Ahlbrandt and others, this volume, fig. 5).

\section{PROCEDURES}

Sedimentology and Depositional Environments

A detailed sedimentologic study was made of the aforementioned cores (Fox and others, 1979) using a thin slice ( $1.25 \mathrm{~cm}$ thick) cut from each of these cores. Sandstone beds make up a relatively small proportion of the overall lithotype of the total cored interval. Interbedded with the thin sandstone units are claystone, siltstone, and coal beds that were not studied for this report. The following aspects were studied in the core analysis: visualporosity estimate, 1ithology, color, grain size, bedding type, sedimentary structures, biologic constitutents, sorting, roundness, oil shows, and inferred environment of deposition.

Data were gathered from the core specimens using a hand lens, binocular microscope, and black-1ight (fluorescence) apparatus. Interpretation of depositional environments was primarily dependent upon the identification of sedimentary structures. Because of the finegrained, homogeneous nature of most of the sediments and the abundance of interstitial clay, the sedimentary structures were difficult to see clearly. For this reason, each of the thin slices of core was photographed using an $\mathrm{X}$-radiography apparatus, and an X-radiograph photograph was printed to assist in interpretation. These prints revealed structures not otherwise clearly distinguishable.

Interpretations of depositional environments for each cored interval (fig. 21) were incorporated into the regional paleogeographic synthesis of Brosgé and Whittington (1966). Microfossils were especially useful in interpreting the environments. Dinoflagellates and foraminifera were identified by F. E. May and W. V. Sliter, respectively. Their results, which are discussed separately in this Circular, were used not only to aid in the paleoenvironmental interpretation, but also to date the 


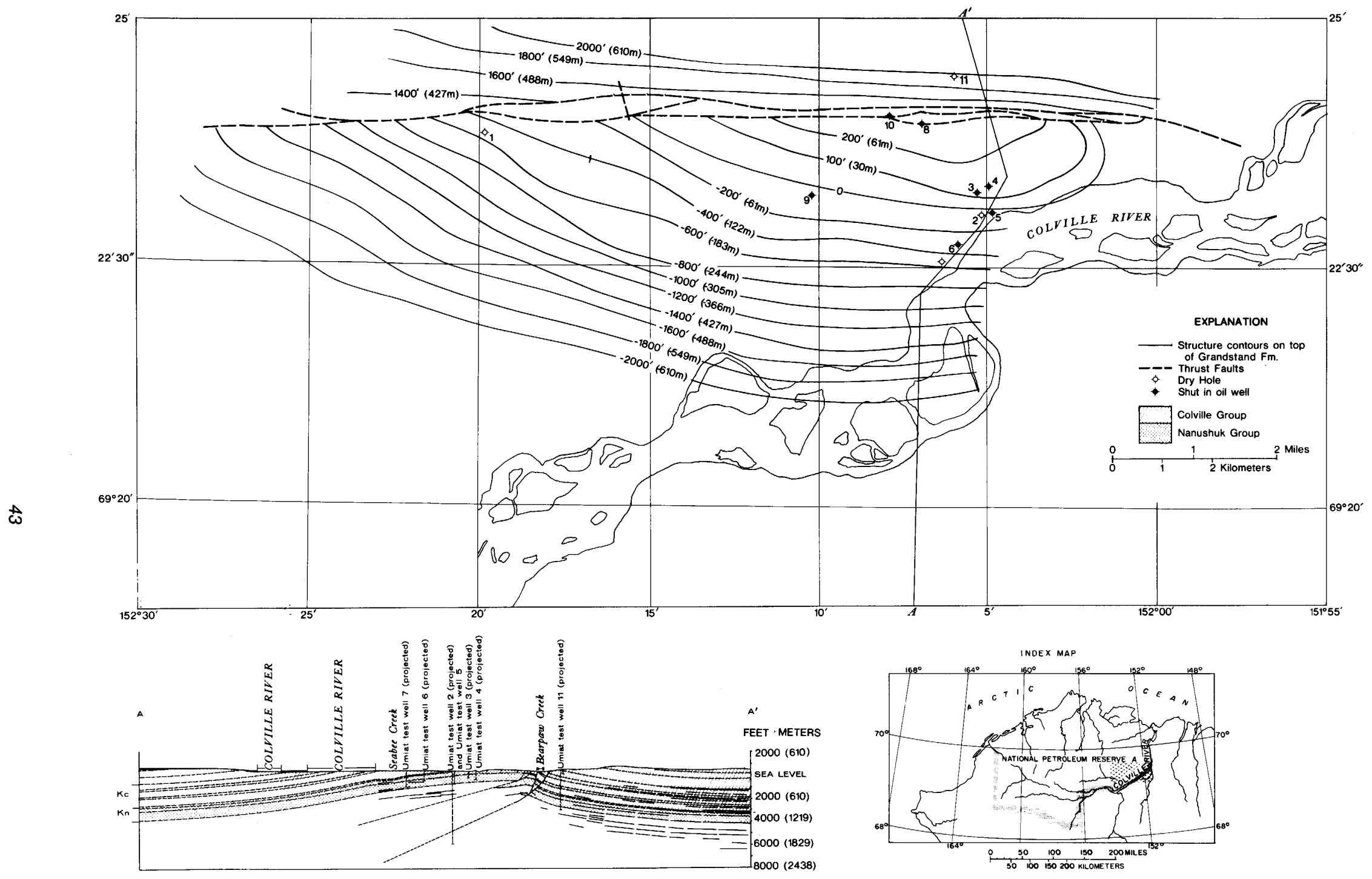

Figure 20.--Index map showing location of study area, structure contour map of Umiat Anticline, and cross section of Umiat Anticline. Modified from Brosgé and Whittington (1966). 


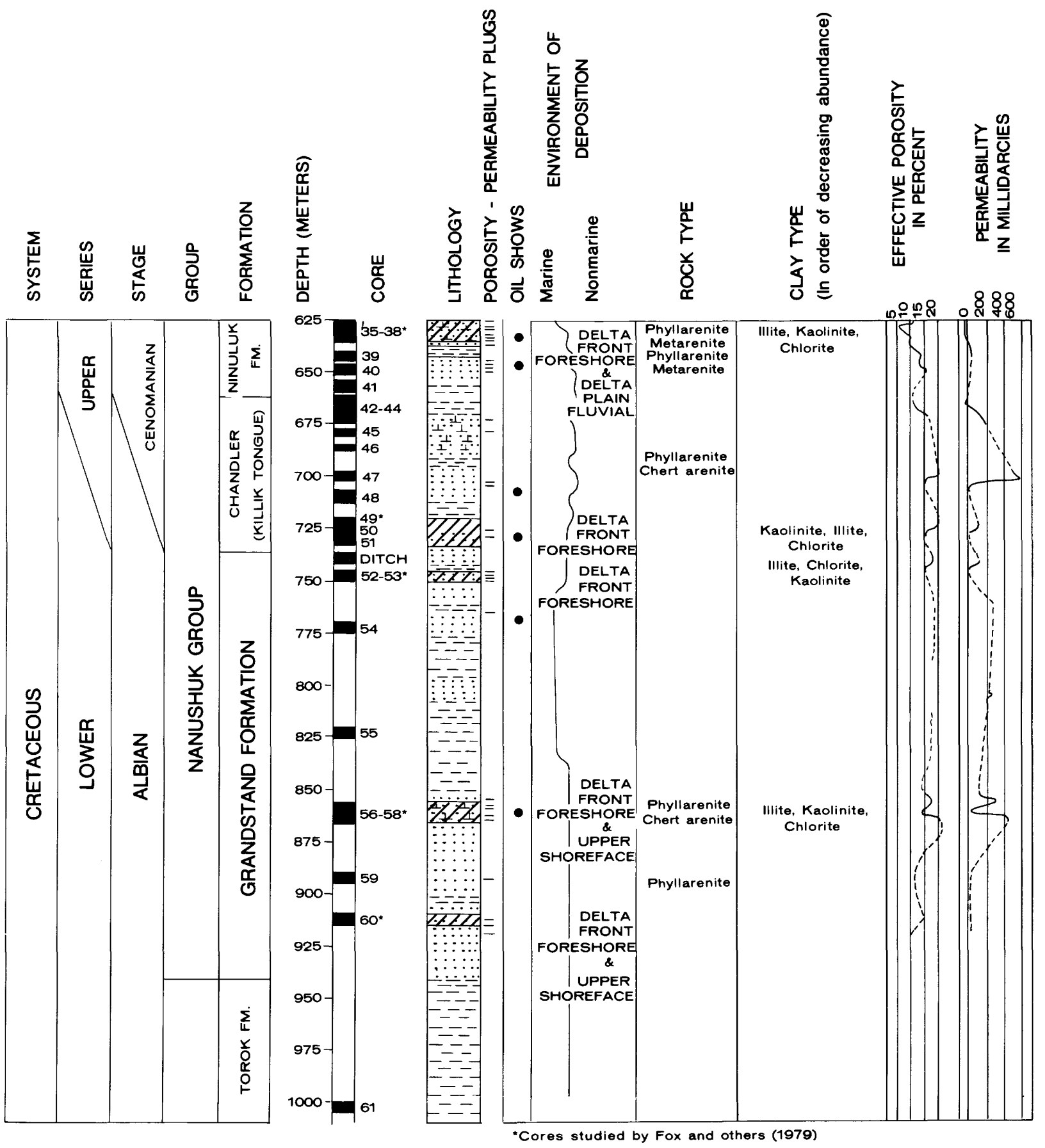

Figure 21.--Stratigraphic column of Umiat test well 11 showing cored intervals, shows of oil, environments of deposition, rock type, clay type, effective porosity, and permeability.

rocks and to set up a framework for biostratigraphic correlation.

\section{Petrography}

Detrital grains and clay minerals were studied in order to determine their effects on reservoir quality (Fox and others, 1979). P. W. Lambert documented the influence of texture, fabric, mineralogy, and diagenesis on reservoir quality in the study by Fox and others (1979). Thirty-one core samples ("perm plugs") from the Nanushuk Group, previously used for porosity and permeability studies (Collins, 1958a), were 
used in the analyses. These studies were supplemented by X-ray diffraction analyses by $\mathrm{J}$. K. Pitman of clay and of major mineral constituents of 21 samples (taken as close as possible to perm-plug locations) from the Nanushuk Group (fig. 21). Of special interest was the identification of the kinds of interstitial clay in the various sandstone units.

\section{RESULTS}

\section{Sedimentology and Depositional Environments}

Strata of the Lower Cretaceous Nanushuk Group in the Umiat area consist of detrital clastic sediments, derived from the Brooks Range to the south. These sediments were deposited in continental (delta plain, Killik Tongue of the Chandler Formation), nearshoremarine (delta front, Grandstand Formation), and offshore-marine (prodelta, Torok Formation) environments (fig. 22) (Fisher and others, 1969). These environments prograded from southwest to northeast as the Cretaceous sea retreated from the area. However, minor transgressions and regressions resulted in complex interbedding of nearshore-marine and continental facies throughout the area. The Ninuluk Formation represents a transgression of the sea over the delta-plain facies of the Killik Tongue.

The interpretations of Fox and others (1979) generally agree with those of Fisher and others (1969). Evidence for the interpretations of Fox and others includes outcrop studies by Brosgé and Whittington (1966), plus paleontologic, sedimentologic, and petrographic interpretations.

The delta was prograding to the northeast, as indicated by thickness relationships shown on figure 22 (Fisher and others, 1969). The delta-plain facies of the Killik Tongue and the delta-front facies of the Grandstand Formation thin to the northeast of Umiat Anticline. At Wolf Creek Anticline, approximately $32 \mathrm{~km}$ west of Umiat, the Grandstand is about $378 \mathrm{~m}$ thick. At Umiat the Grandstand is about $195 \mathrm{~m}$ thick, thinning about $183 \mathrm{~m}$ in $32 \mathrm{~km}$; the Grandstand is absent in the Fish Creek we11, about $113 \mathrm{~km}$ north of Umiat.

\section{Grandstand Formation}

Three lines of compositional and textural evidence are used to infer the depositional setting of the Grandstand Formation. First, in the Knifeblade and Titaluk wells, 80-95 km west of Umiat (fig. 22), thin coal beds are common throughout the Grandstand. However, at Umiat, coal streaks and partings in the Grandstand are rare, suggesting more typical marine conditions. Second, according to Brosgé and Whittington (1966), sandstone beds of the Grandstand at Umiat Anticline are cleaner (less interstitial clay and mica) than those to the west at Wolf Creek and Square Lake wells, possibly due to winnowing in the foreshore zone. Third, the grain size of sandstone of the Grandstand Formation decreases to the east, ranging from very fine to coarse at Knifeblade, very fine to medium at Titaluk, and very fine to fine at Wolf Creek and Square Lake (Brosgé and Whittington, 1966). These regional compositional, textural, and thickness relationships suggest that the depocenter for Grandstand sandstones lay to the west-southwest of the Umiat area. This delta is referred to as the Umiat delta by Ahlbrandt and others (this volume). The aforementioned interpretation of depositional patterns in the Grandstand is further supported by the general coarseningupward gradation from shale to siltstone to sandstone at Umiat, indicating a progradational sequence.

Faunal evidence suggests a shallow-water nearshore-marine environment for deposition of the Grandstand sediments at Umiat (fig. 21). Nearly all of the shale beds and some of the sandstone beds contain abundant benthonic arenaceous microfossils of the Verneulinoides borealis assemblage (Bergquist, in Collins, 1958a). Arenaceous forams are commonly present in shallow nearshore-marine environments. A moderately rich assemblage of dinoflagellates, spores, and pollen also occurs throughout the Grandstand (May, this volume; E. I. Robbins, oral commun., 1976), as would be expected in sediments deposited in a nearshore-marine environment. The dinoflagellate assemblage is of middle to late Albian age (May, this volume). Marine invertebrate megafossils (primarily mollusks) occur throughout the Grandstand sequence (Brosgé and Whittington, 1966).

The following section presents a discussion of the compositional and textural aspects and the inferred environments of deposition of selected cores of the Nanushuk Group, Umiat test well 11 .

Cored interval $60(911-916 \mathrm{~m})$ (fig. 23) is near the base of the Grandstand Formation and the contact with marine siltstone and shale of the underlying Torok Formation. The very fine grained to fine-grained, well-sorted, subangular to angular nature of the sandstone and the predominance of thin, low-angle, parallel laminations that are interbedded with some homogeneous bioturbated beds indicate deltafront sands deposited in an upper-shoreface (bioturbated) and foreshore-marine (low-angle, para1lel, thin laminations) environment. Cored intervals 56-58 (856-869 m) (fig. 24) are near the top of the basal sandstone unit of the Grandstand. The fine-grained, well-sorted nature of the sandstone; the presence of a thin $(0.6 \mathrm{~m})$, homogeneous, bioturbated sandstone interval near the base, which is overlain by a thicker interbedded interval (4.5 m) containing low-angle, parallel laminae; and small-scale lenticular crossbed sets support deposition as delta-front sands in a dominantly foreshore zone. This sequence grades upward into another bioturbated homogeneous sandstone 


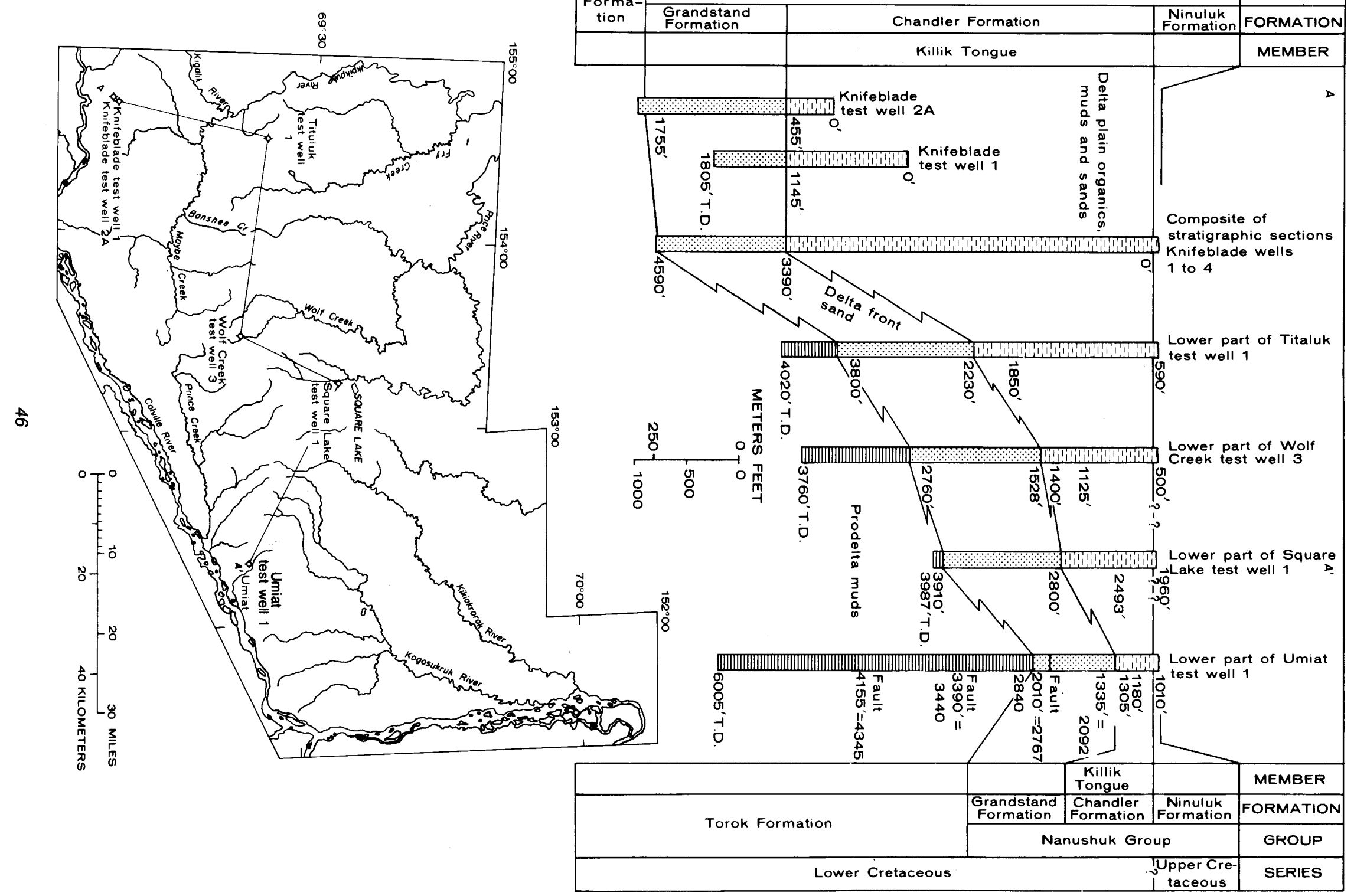




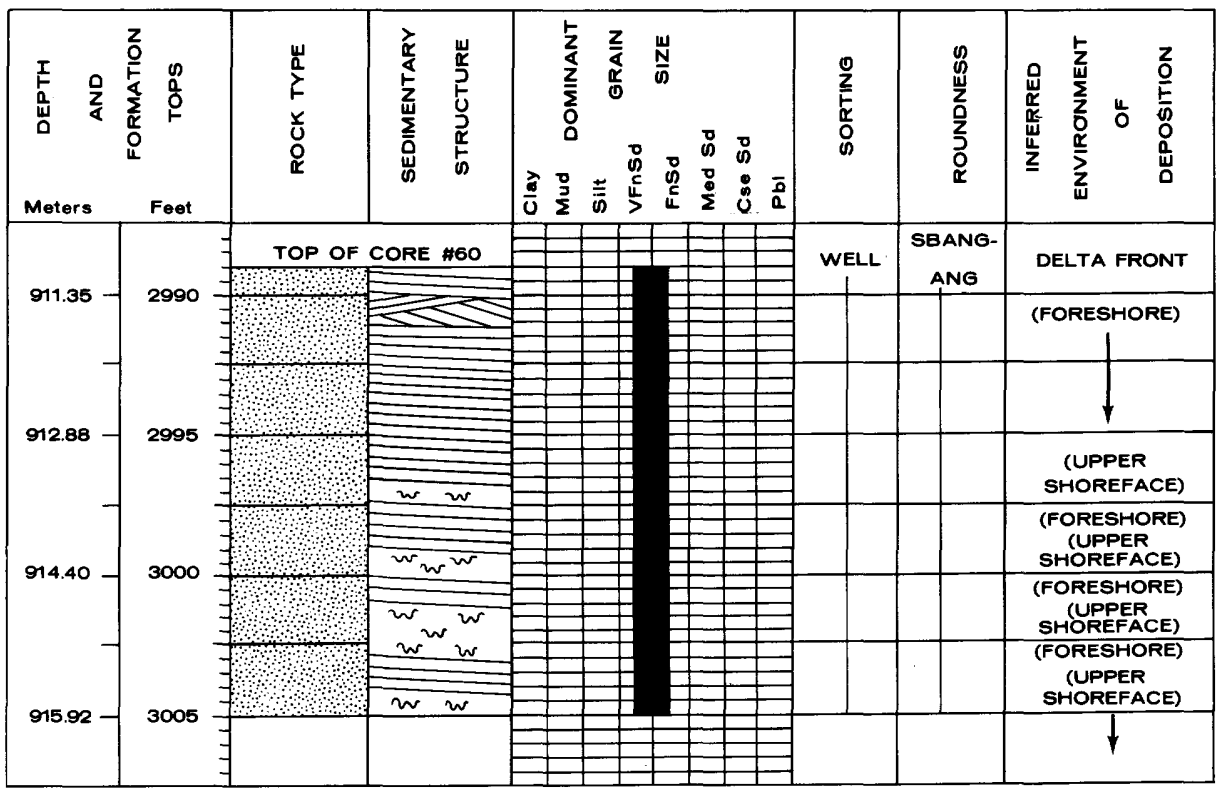

EXPLANATION

SYMBOLS:

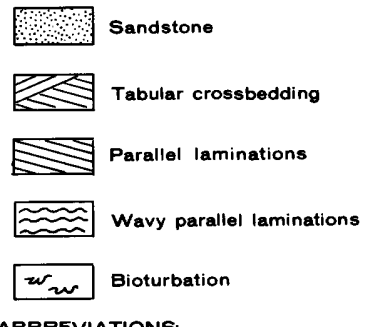

ABBREVIATIONS:

VFn Sd - very fine grained sand

Fn Sd - fine-grained sand

Med Sd - medium-grained sand

Cse Sd - coarse-grained sand

$\mathrm{Pbl}$ - pebble

Ang - angular grains

Sbang - subangular grains

Well - well-sorted grains

Figure 23.--Lithology, sedimentary structures, texture, and inferred environment of deposition, core 60, Grandstand Formation, Umiat test well 11.

Figure 22.--Deltaic interpretation of Lower Cretaceous rocks of eastern NPRA. From Fisher and others (1969). Location of test well sites shown by $A_{-1}^{\prime}$.

unit, reflecting a slight marine incursion and deposition of delta-front sands in a shoreface zone. A thin shale bed $(0.3 \mathrm{~m})$ separates the aforementioned $4.5-\mathrm{m}$-thick sandstone interval from the overlying sequence of sandstone, which is of approximately the same thickness. This upper sandstone unit differs from the lower by having more carbonaceous laminae, more abundant rippled laminae (asymmetric), and near absence of bioturbation. Occasional flooding during deposition of this upper sandstone unit may have been responsible for the abundant carbonaceous detritus being carried so far offshore and for the formation of the higher energy asymmetric ripples. These thin carbonaceous laminae may be time-equivalent to thicker coal stringers to the west.

The sequence of predominantly nearshoremarine sandstone is overlain by a marine shale sequence $(55 \mathrm{~m})$, reflecting continued transgression of the sea. Abundant arenaceous and calcareous benthonic foraminifera, abundant dinoflagellates, and some spores and pollen exist in the shale. This combination of fossils is commonly found in modern nearshore-marine environments. This shale sequence may have been deposited as prodelta muds.

Cores 52 and $53(745-750 \mathrm{~m})$ (fig. 25) are from about $3 \mathrm{~m}$ below the top of the Grandstand Formation. This sandstone interval is similar to the lower $(4.5-\mathrm{m})$ interval just described from cores 56-58 and is also interpreted as a delta-front sand deposited in a foreshore environment. However, correlation with coal stringers to the west-southwest of Umiat is not obvious. The only evidence is black carbon grains evenly disseminated throughout the sandstone and concentrated in thin laminations on bedding surfaces. As was the case with the foreshore sandstone of interval 60, the sandstone of this interval is also overlain by a transgressive shale. In this interval the shale is only $10 \mathrm{~m}$ thick and contains a rich fauna of arenaceous forams (Bergquist, in Collins, 1958a).

\section{Chandler Formation (Killik Tongue)}

The Chandler Formation is predominant1y nonmarine at its type locality where it consists of two major tongues, the Killik Tongue and the Niakogon Tongue (Detterman, 1956). The Niakogon Tongue is not differentiated from the Ninuluk Formation in the Umiat area (Brosge and Whittington, 1966).

Brosgé and Whittington (1966) interpreted the sandstone, siltstone, shale, and coal of the Killik Tongue in the area to the southwest of Umiat as having been deposited in fluvial and related environments. Between this area and Umiat, a facies change occurs, from the well-developed delta-plain facies just described to a dominantly nearshore-marine facies at Umiat. Moreover, at Umiat, coal in the Killik Tongue is restricted to just a few thin stringers $(10 \mathrm{~cm})$ near its top. Furthermore, the Killik Tongue progressively thins in a northeasterly direction, from about $1,036 \mathrm{~m}$ at 


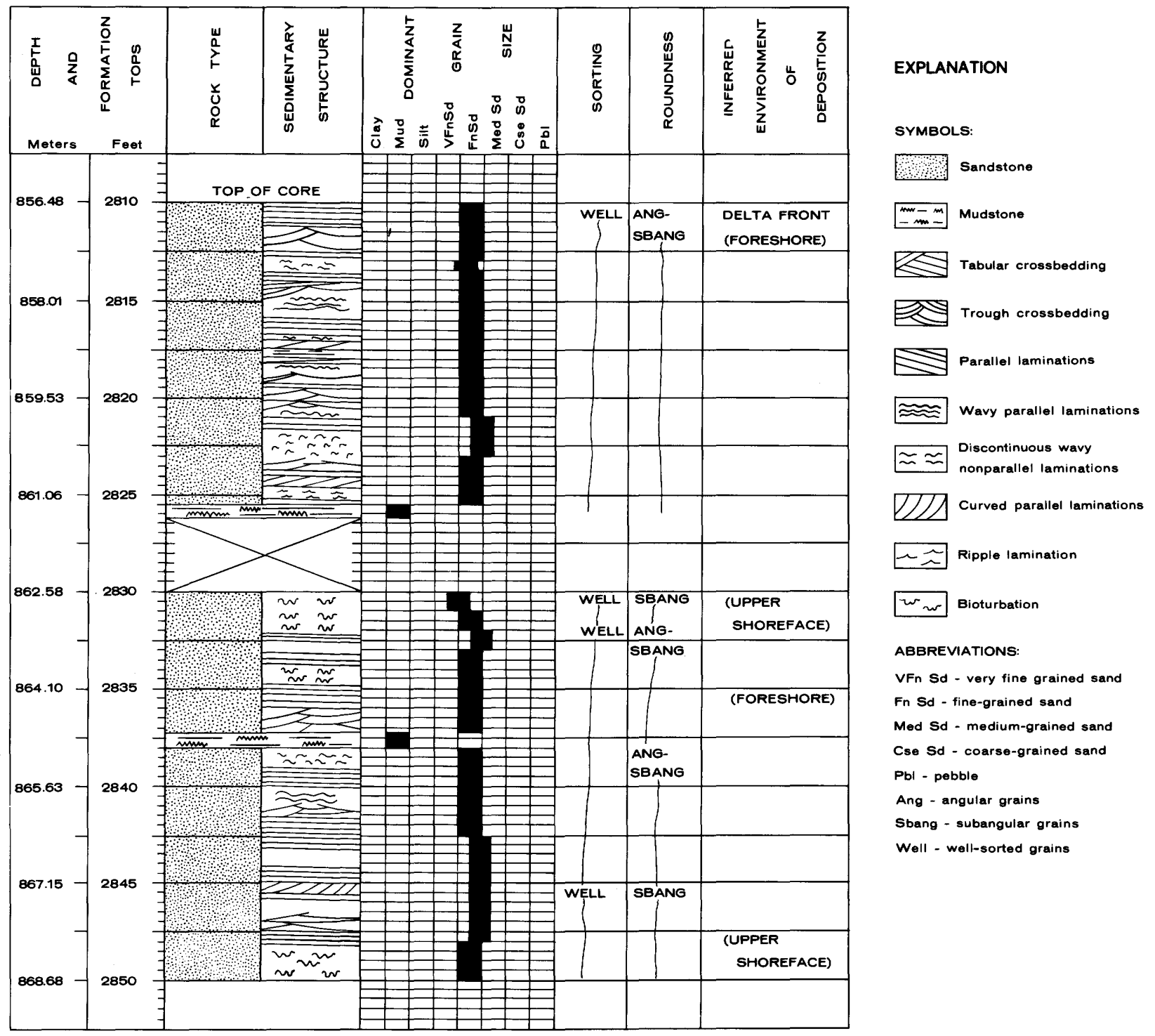

Figure 24.--Lithology, sedimentary structures, texture, and inferred environment of deposition, cores 56-58, Grandstand Formation, Umiat test well 11.

Knifeblade Anticline (fig. 22) to about $90 \mathrm{~m}$ at Umiat. This thinning is depositional, reflecting increased distance from the source area. At Umiat, the Killik Tongue contains a nearshore-marine dinoflagellate and acritarch assemblage of low to moderate diversity. This assemblage is used to establish an age of middle Albian to early Cenomanian(?) (May, this volume).

Core 49 (724-729 m) (fig. 26) is from the Killik Tongue. The sandstone of this core is fine to very fine grained, well sorted, and subangular; it consists of small-scale, lenticular, crossbed sets of thin laminae interbedded with small-scale, low-angle, parallel sets of thin laminae.
Although the sedimentologic data are not definitive, the flora and fauna, textural attributes, and thickness trends suggest deposition near the marine shoreline; the welldeveloped delta-plain facies lies to the west.

\section{Ninuluk Formation}

In the Umiat area the Ninuluk Formation overlies the Killik Tongue of the Chandler Formation and is the youngest dominantly marine formation of the Nanushuk Group. The Ninuluk thins from about $280 \mathrm{~m}$ near Weasel Creek Anticline (fig. 20) to about $29 \mathrm{~m}$ at Umiat, a distance of about $48 \mathrm{~km}$ to the northeast (Brosgé and Whittington, 1966). This trend to the 


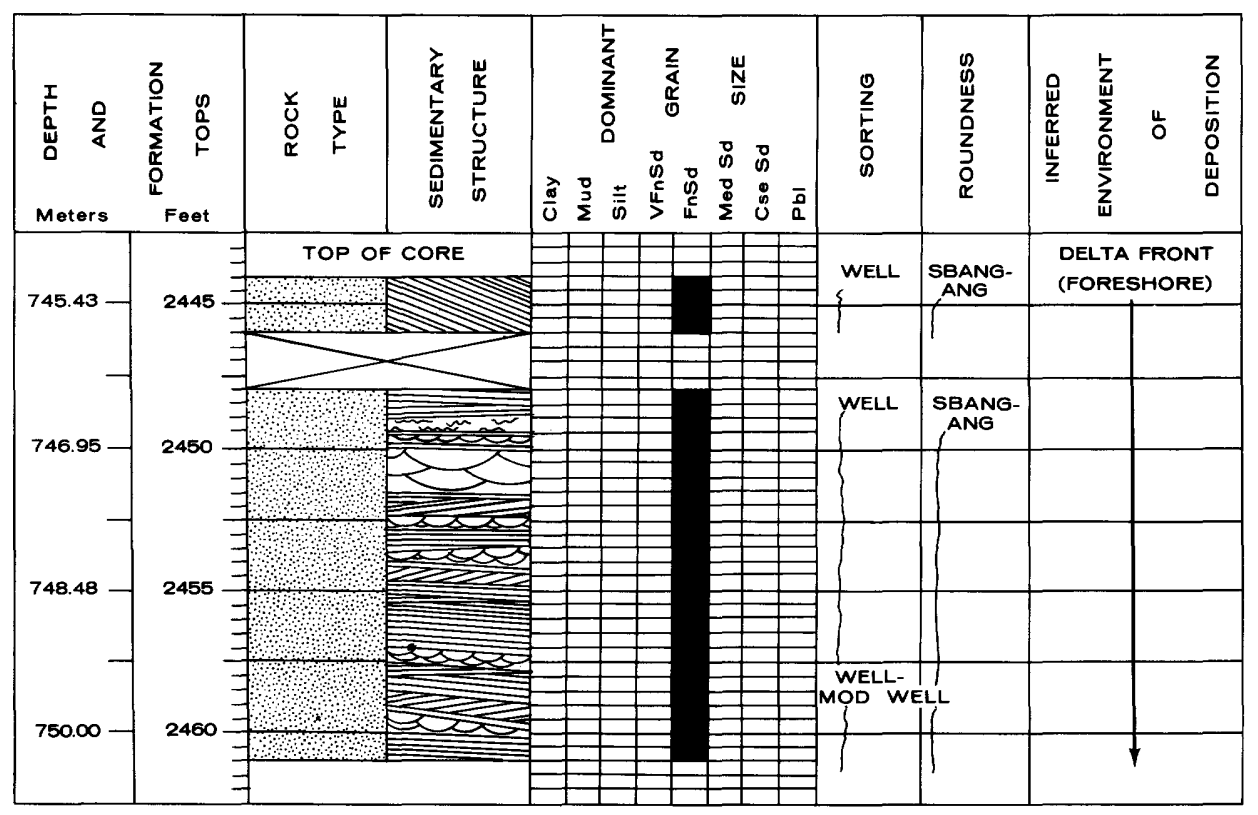

EXPLANATION

SYMBOLS

Sandstone

Tabular crossbedding

Trough crossbedding

$\approx$ Parallel laminations

$\approx \approx$ Discontinuous wavy

ABBREVIATIONS:

VFn Sd - very fine grained sand

Fn Sd - fine-grained sand

Med Sd - medium-grained sand

Cse Sd - coarse-grained sand

Pbl - pebble

Ang - angular grains

Sbang - subangular grains

Well - well-sorted grains

Mod - moderately sorted grains

Figure 25.--Lithology, sedimentary structures, textures, and inferred environment of deposition, cores 52 and 53, Grandstand Formation, Umiat test we11 11.

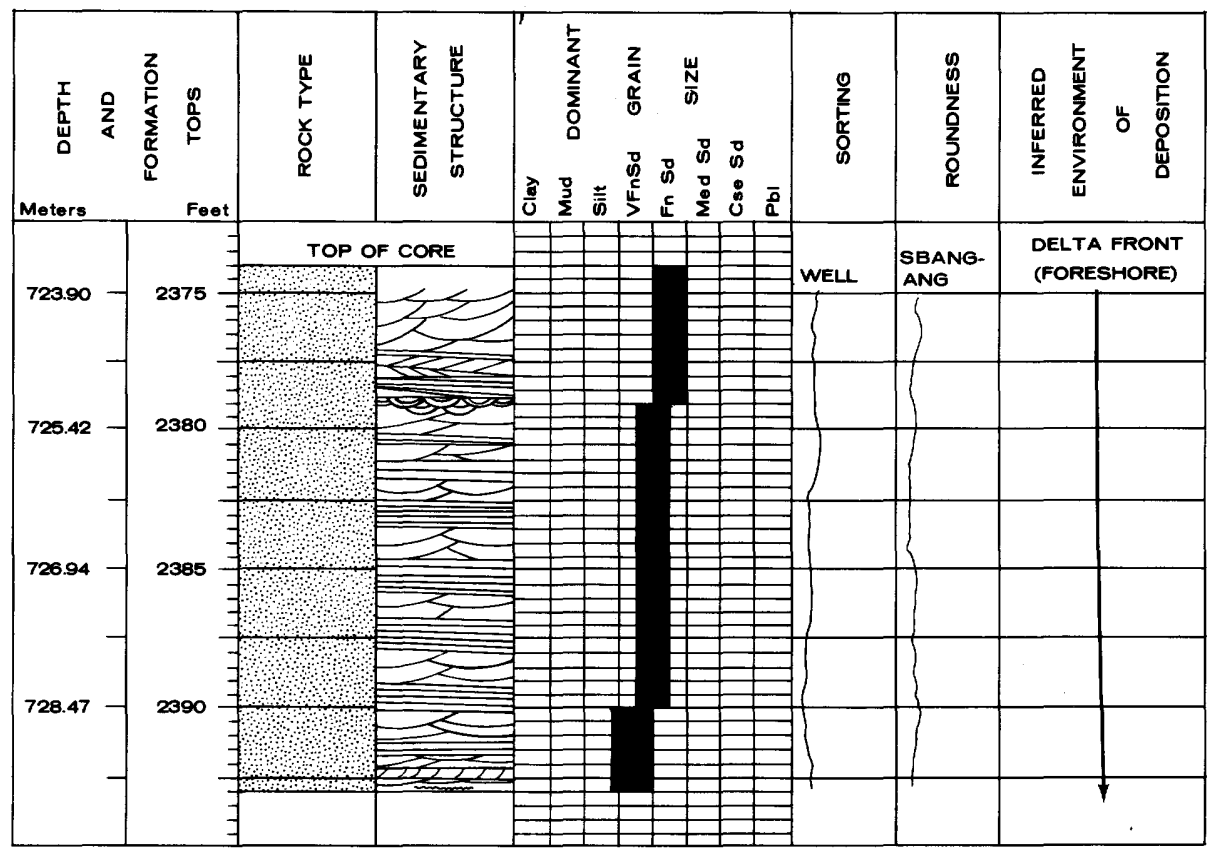

EXPLANATION

SYMBOLS:

Sandstone

Tabular crossbedding

Trough crossbedding

Parallel laminations

$\approx \approx \approx$ Wavy parallel laminations

P) curved parallel laminations

ABBREVIATIONS

VFnSd - very fine grained sand

Fn Sd - fine-grained sand

Med Sd - medium-grained sand

Cse Sd - coarse-grained sand

Pbl - pebble

Ang - angular grains

Sbang - subangular grains

Well - well-sorted grains

Figure 26.--Lithology, sedimentary structures, texture, and inferred environment of deposition, core 49, Killik Tongue of the Chandler Formation, Umiat test well 11.

northeast in direction of thinning is similar to that previously described in underlying rocks of the Nanushuk Group. In contrast, the overlying marine sequence of the Upper Cretaceous Seabee Formation thickens to the northeast.
In the Maybe Creek area, approximately 64 $\mathrm{km}$ west of Umiat, the Ninuluk consists of complexly interbedded sediments containing nonmarine fossils and coal interbedded with beds containing shallow-marine fossils (Brosge and Whittington, 1966). 
Cores 35-38 (624-639 m) (fig. 27) are from the Ninuluk Formation. These rocks are predominantly very fine grained to fine-grained, moderately well sorted to well-sorted, angular to subangular sandstone. A thin unit $(1.2 \mathrm{~m})$ near the base is moderately well to poorly sorted, is angular to rounded, and contains coaly laminae. In this basal unit are thin beds of poorly sorted clay pebble conglomerate (clay clasts as large as $2.5 \mathrm{~cm}$ in diameter) in a clay matrix, which are interbedded with moderately well sorted, thin, very. fine grained to fine-grained beds. Immediately above this basal 1.2-m unit, small-scale, curved-parallel and discontinuous, wavy, nonparallel coaly laminations are present. The lower part of this interval contains a moderately abundant assemblage of dinoflagellate (F. E. May, oral commun., 1978). These were not datable, but they are similar to those of the underlying Killik Tongue (middle Albian to early Cenomanian) (May, this volume). In turn, above that interval are small-scale, low-angle, parallel laminae of sandstone interbedded with homogeneous unstructured sandstone overlain by a few thin sandstone beds $(15 \mathrm{~cm})$ having lenticular crossbeds. The upper part of the cored interval was barren.

On the basis of sedimentary structures, fossils, and thickness trends, the Ninuluk in the Umiat area was deposited, in large part, as delta-front sands in a shallow-marine foreshore environment, seaward from the typical deltaplain facies of the Ninuluk at the Maybe Creek area to the west (fig. 22). The basal 1.2-mthick unit may be a fluvial deposit of a delta-plain environment or an intertidal mud flat.

\section{Petrography}

Grandstand Formation and Killik Tongue of Chandler Formation

Detrital clasts.--The following petrographic summary is from Lambert (in Fox and others, 1979). Rock samples that were analyzed from the Grandstand Formation and Killik Tongue of the Chandler Formation are petrographically similar. They are primarily composed of wellsorted, very fine to fine, angular to subangular detrital grains. These sandstones, although texturally mature, are compositionally immature, consisting of little quartz, much chert and metamorphic rock fragments, and minor feldspar. Mineralogically they are classified as chert arenites and phyllarenites (fig. 21), relatively poor in quartz and rich in lithic fragments. Quartz grains are generally strained. Most plagioclase grains exhibit albite twinning and are generally unzoned and unaltered; grains of alkalic feldspar are also mostly unaltered. Detrital chert is mostly microcrystalline. Chert clasts contain inclusions of clay, euhedral crystals of pyrite and dolomite, and patches of length-slow and length-fast chalcedonic chert.

Metamorphic rock fragments include phyllite and metaquartzite. Phyllite fragments are composed of sericite, chlorite, and anhedral crystals of quartz and are squeezed between and around other harder detrital grains forming pseudomatrix. Metaquartzite fragments are identical to phyllite fragments, but contain more than 50 percent quartz. This quartz content is highly variable. Deformation of metaquartzite fragments depends on the abundance of sericite; the greater the sericite content, the greater the deformation.

Another assemblage of rock fragments exists in trace amounts in several samples. It consists of plagioclase microlites oriented in a random or subparallel arrangement in a chloritic groundmass. In some samples groundmass is more abundant than plagioclase; in others it is less abundant.

Biotite is a minor accessory mineral, which is sometimes partially altered to chlorite. Organic matter exists as highly deformed masses and stringers as long as $4 \mathrm{~mm}$; it lacks cellular form. Other detrital components occur in small amounts and will not be discussed. (Refer to Fox and others (1979) for further information.)

Matrix material.--The amount of matrix (smaller than $30 \mu \mathrm{m}$ ) is highly variable, and matrix is of both detrital and authigenic origin. The matrix consists of sericite and chlorite flakes and quartz grains, most of which are detrital and have resulted from disintegration during weathering and erosion of parent rock (phyllite and metaquartzite) and abrasion during transportation. Illite, chlorite, and kaolinite have been detected by J. K. Pitman (written commun., 1978) in the $<2 \mu \mathrm{m}$ fraction via X-ray diffraction analysis. The presence of a sharp, well-ordered 10-A peak for clay material identified as illite may indicate that it is detrital sericite rather than authigenic illite. Chlorite peaks are also sharp and well ordered; the chlorite may be, in part, detrital metamorphic rather than authigenic. Smectite was not detected. However, many of the larger detrital grains are etched and slightly embayed by matrix material, indicating an authigenic origin of at least some of the matrix phyllosilicates. Also, coatings of what is very likely authigenic(?) sericite, chlorite, and possibly illite exist locally along some of the larger detrital grain contacts.

Quartz overgrowths commonly exist on detrital quartz grains, projecting into, but rarely completely filling, intergranular pores. Other authigenic minerals include intergrown masses of vermicular crystals of kaolinite that completely fill some pores. Chert, pyrite, small flakes of chlorite, and several kinds of carbonate minerals also are present. These carbonate minerals include dolomite rhombs, 


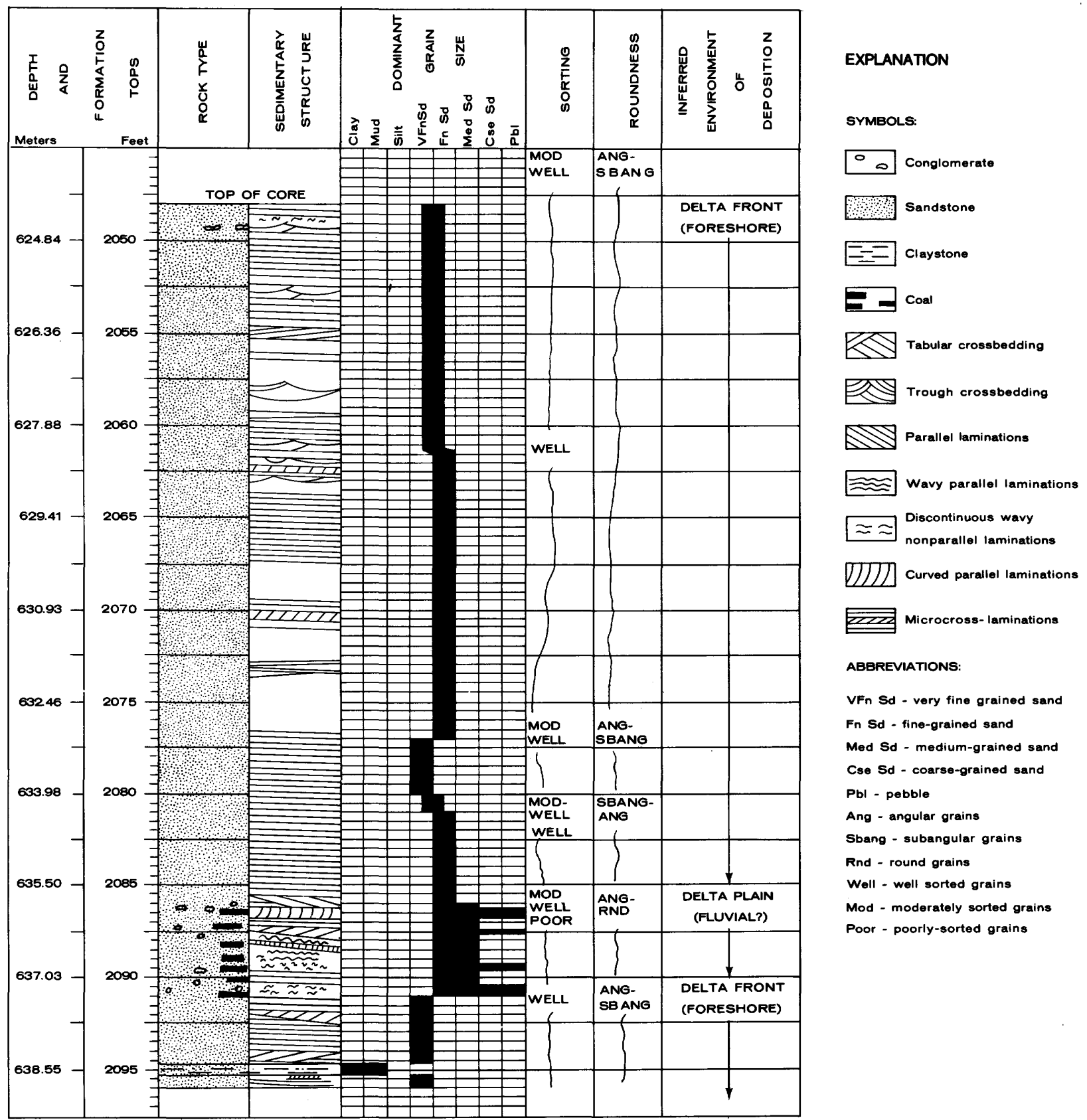

Figure 27.--Lithology, sedimentary structures, texture, and inferred environment of deposition, cores 35-38, Ninuluk Formation, Umiat test wel1 11 .

which often replace adjacent detrital silicate and siderite grains. These rhombs are single crystals of subhedral to euhedral form, which are distributed evenly through the rock or which occur as equidimensional clusters as much as $250 \mu \mathrm{m}$ across. Calcite is commonly present in small amounts, as sparry anhedral to rhombshaped individuals, each composed of one crystal, or as many small anhedral crystals that may represent recrystallized, originally detrital carbonate grains. Many of the grains have twin 1 amellae that are unbent, suggesting further that recrystallization occurred after compaction. Less commonly, calcite occurs as large, optically continuous (poikilotopic) crystals as much as $800 \mu \mathrm{m}$ across that slightly replace detrital silicates. 
Porosity.--Porosity and permeability are high for the Grandstand and Killik samples studied (fig. 21). Most porosity is primary and intergranular; secondary porosity due to leaching of feldspar grains is minor. Visible pores (visible at magnifications up to about $800 \mathrm{x}$ ) have an average size of about $50 \mu \mathrm{m}$. They are generally triangular, equant, or crescent-shaped spaces between noncompressible grains such as quartz, feldspar, and chert. Many of the pore walls are formed of straightedged quartz overgrowths, and these are free of phyllosilicate coatings.

\section{Ninuluk Formation}

Detrital clasts.--The sandstone samples studied from the Ninuluk Formation are very fine to fine grained. They are relatively poor in quartz and rich in chert and metamorphic rock fragments, characteristics similar to those of the previously discussed Grandstand Formation and Killik Tongue (fig. 21). However, other petrographic features of the Ninuluk contrast sharply with those of the underlying units. First, Ninuluk rocks are more poorly sorted, often with a bimodal distribution. Second, metamorphic rock fragments are more abundant than chert fragments, which is not the case for the Grandstand and Killik. Metaquartzite fragments are very common and constitute a greater portion of rock fragments in the Ninuluk than does phyllite in the underlying units, where phyllite is the most abundant. Ninuluk samples also contain less detrital quartz than do those of the Grandstand and Killik. The Ninuluk contains a considerable amount of carbonate in its upper part.

Some phyllite fragments contain relatively large flakes of sericite (as large as $100 \mu \mathrm{m}$ in diameter), some contain biotite, and others contain clinozoisite(?). The phyllite grains are wedged between noncompressible detrital grains and, when present, form abundant pseudomatrix that significantly reduces both porosity and permeability.

Matrix material.--Matrix material in the Ninuluk, as determined by X-ray diffraction analysis, consists of illite, chlorite, and kaolinite; smectite is absent (fig. 21). In thin section the matrix material is the same as that in the Grandstand and Killik, previously discussed.

Authigenic cement in sandstones studied consists of calcite, quartz, siderite, and chlorite. Calcite in the Ninuluk exists mainly as anhedral to euhedral crystals that may be recrystallized detrital carbonate grains. Many of the grains exhibit twinning, a condition similar to that in the Grandstand and Killik. Much calcite, though, is definitely authigenic and replaces detrital silicate and detrital calcite grains along grain boundaries. Quartz overgrowths are less abundant in the Ninuluk
Formation than in the Grandstand Formation and Killik Tongue. Siderite crystals occur in great numbers along boundaries of detrital silicate grains. Siderite grains preferentially replace phyllite fragments and locally replace calcite. They occur along the contact between detrital quartz and quartz overgrowths, but not on free surfaces of quartz overgrowths.

Sparse, green, finely crystalline aggregates of chlorite may be authigenic.

The abundance of metamorphic rock fragments, chert, and detrital carbonate grains, and the low content of quartz suggest that the source rocks for these sandstones were dominant1y limestone and low-grade metamorphic rocks, most probably from pre-Cretaceous rocks that are present in the Brooks Range to the south (Brosgé and Tailleur, 1971; Grybeck and others, 1977; Bartsch-Winkler, this volume).

\section{Porosity.--Porosity is mostly intergranu-} lar. Visible pores average about $35 \mu \mathrm{m}$ in size and are triangular, equant, or elongate. They are not filled with matrix, deformed phyllite grains, or authigenic carbonate.

\section{RESERVOIR QUALITY}

The following conclusions regarding factors having an effect on porosity and permeability of the Grandstand Formation, Killik Tongue of the Chandler Formation, and Ninuluk Formation are based on a comprehensive petrographic study by Lambert and log study by Wu (in Fox and others, 1979). On the basis of petrography, Lambert made the following conclusions regarding reservoir quality:

1. No relationship exists between compaction (influenced by depth of burial) and porosity and permeability; deeper samples in Umiat test well 11 are just as porous and more permeable than shallow samples. This is due to abundant intergranular porosity in deeper samples and abundant matrix in shallower samples.

2. Modal grain size is a minor factor affecting porosity and permeability. Porosity and permeability in all samples increase with increasing grain size; a minimum grain size of about $175 \mu \mathrm{m}$ is necessary for good permeability (>50 md).

3. Rocks with the best porosity and permeability have very low amounts of compressible grains, matrix, and authigenic carbonate. Rocks with the best permeability are chert arenites, and those with the poorest permeability are phyllarenites.

4. Factors controlling phyllite and matrix abundance may be related to environment of deposition. In high-energy environments, phyllite fragments may be disintegrated and winnowed away, leaving a more porous and permeable sandstone. The best reservoirs can be expected in those parts of the basin where 
high-energy conditions (beaches) existed and (or) where only sparse amounts of metamorphic rock debris were being deposited.

5. Petrographically identical phyllite fragments occur in both high- and low-phyllite sandstones. But, on the other hand, changes in phyllite content occur through small vertical distances $(2-3 \mathrm{~m})$. Because of these characteristics, change in provenance does not seem to be a factor controlling phyllite abundance in Nanushuk rocks of Umiat well 11.

6. As modal size of visible pores decreases, so does permeability.

7. As percent of pore wall coated by phyllosilicate increases, permeability decreases.

Porosity values were calculated for each of the formations by Wu (in Fox and others, 1979) using cores and well logs. Weighted average porosity values are as follows:

Lower part of the Grandstand Formation--15.1 percent;

Upper part of the Grandstand Formation--15.6 percent;

Killik Tongue, Chandler Formation--16.4 percent;

Ninuluk Formation--12.6 percent.

Wu (in Fox and others, 1979) studied relationships between porosity and permeability and found that a linear relationship may exist between porosity and permeability for rocks at depths less than $400 \mathrm{~m}$ and for rocks at depths greater than $640 \mathrm{~m}$ (fig. 28). Permafrost may affect the porosity and permeability at depths of $400 \mathrm{~m}$ or less. Wu predicted that the permeability of rocks at depths greater than $640 \mathrm{~m}$ will be less than $1 \mathrm{md}$ if porosity is less than 9 percent.

Weighted average permeability values are as follows:
Lower part of the Grandstand Formation--58.6 md;

Upper part of the Grandstand Formation-$167.0 \mathrm{md}$;

Killik Tongue, Chandler Formation--96.2 md; Ninuluk Formation--10.7 md.

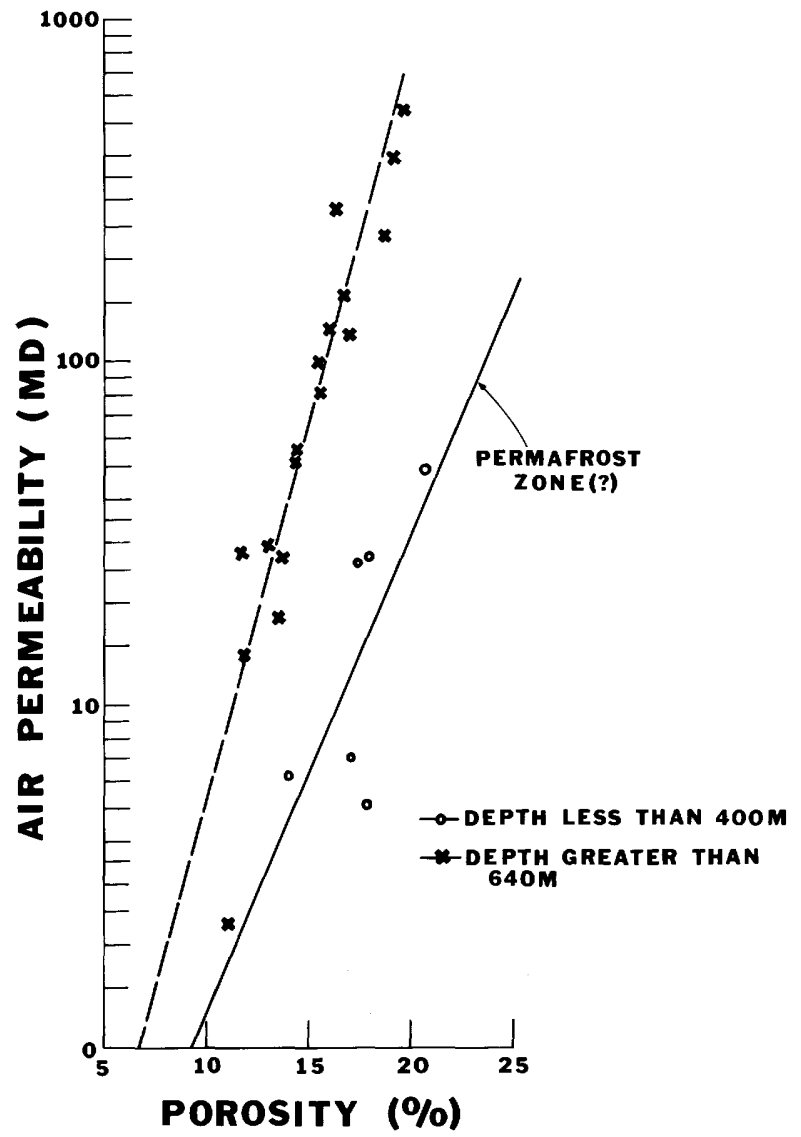

Figure 28.--Porosity and permeability relationships of Cretaceous rocks, Umiat test well 11. 
HYDROCARBON SOURCE POTENTIAL OF THE

NANUSHUK GROUP AND THE TOROK FORMATION, A PRELIMINARY REPORT

By Leslie B. Magoon and George E. Claypool

\section{INTRODUCTION}

Preliminary results are presented here for the hydrocarbon source potential of three wells and one outcrop section of the Nanushuk Group (Lower and Upper Cretaceous) and part of the underlying Torok Formation (Lower Cretaceous). Additional data on these rocks have yet to be acquired, which could modify some of these observations.

The data presented here are part of a larger oil and gas source-rock study that has two objectives: (1) to help locate and evaluate the wells being drilled in NPRA (National

Petroleum Reserve in Alaska), and (2) to provide a data base for a more objective oil and gas resource appraisal of NPRA. Geochem Research, Inc., under the direction of Stephen J. Martin, is primary contractor for the basic analytical work. Global Geochemistry, secondary contractor, is doing some of the more specialized analytical work. Petroleum Information Corp. is building the geochemical data file and providing most of the graphical displays. We are responsible for the overall management, design, and interpretive results of the NPRA source-rock program, which includes monitoring of quality control and initial interpretation of the data. The outcrop samples analyzed for this paper were provided by Thomas S. Ah1brandt. The core material from the wells came from the U.S. Geological Survey sample library in Anchorage, Alaska.

The location of the four sections of the Nanushuk Group included in this report are shown in figure 10 (Bird and Andrews, this volume) and, from west to east, are as follows: (1) type section of Kukpowruk Formation (sec. 22, T. 2 S., R. 45 W.); (2) Kaolak No. 1 wel1 (sec. 25, T. 7 N., R. 34 W.); (3) Topagoruk No. I well (sec. 25, T. 15 N., R. $16 \mathrm{~W}$. ), and (4) Umiat test well 11 (sec. 27, T. 1 N., R. 1 W.). Rather than discuss the amount and type of organic material and thermal history of each outcrop or well individually, comments will be made about each analytical parameter for all the sections, with a summary at the end.

\section{AMOUNT AND TYPE OF ORGANIC MATERIAL}

\author{
Organic Carbon Content
}

Total organic carbon content is measured by the combustion method; it includes both "live" carbon--that which can be converted to organic compounds--and "dead" carbon. The observed organic carbon content, in weight percent, ranges from a low of 0.19 to a high of 69.79 and is generally greater than 1 (table 3). Many of the high values are attributed to coal. Values for the Kukpowruk type section, in which very little coal occurs, range from 1 to 2 weight percent, whereas in the Kaolak No. 1 well, the Nanushuk Group includes coaly beds that contain more than 5 weight percent organic carbon (fig. 29). The Nanushuk Group in the Topagoruk No. 1 well and Umiat test well 11 has organic carbon values of less than 5 and little or no coal is logged ( $\mathrm{fig}$. 30).

A commonly accepted lower limit of organic carbon for a hydrocarbon source rock is 0.4 (Dow, 1977a, p. D2). On the basis of this criterion, much of the Nanushuk Group and Torok Formation are potential hydrocarbon source rocks; and, indeed, oil shows were encountered while drilling Kaolak No. 1 well, Topagoruk No. 1 well, and Umiat test wel1 11 (Collins, 1958a, b, c; figs. 29 and 30 ).

\section{TEA-FID}

Thermal-evolution analysis employing a flame ionization detector (TEA-FID) was used to evaluate the richness, type, and thermal maturity of organic matter in sedimentary rocks of the Nanushuk Group. In this analysis, a small sample of rock is heated under controlled conditions and hydrocarbons are measured as they are thermally evolved from the rock. Response of the detector is calibrated by analysis of known amounts of synthetic standard (4.24 percent $\mathrm{n}-\mathrm{C}_{20} \mathrm{H}_{42}$ on $\mathrm{Al}_{2} \mathrm{O}_{3}$ ). Separately measured are $(\overline{1})$ hydrocarbons present in the rock (peak $I$ ), and (2) the absolute temperature required to cause a maximum in pyrolysis prod- 
ucts of the organic matter in the rock ( $T$ peak $\mathrm{II}^{\circ} \mathrm{C}$ ). General interpretation of the results of this type of analysis is summarized by Barker (1974a, b), Claypool and Reed (1976), and Espitalie and others (1977).

Analyses of rock samples by TEA-FID are listed in table 3. Total pyrolytic hydrocarbon yield (PHC) is the sum of peak I and peak II, reported in weight percent relative to the dry weight of the rock. Volatile hydrocarbon content (VHC) is the area of peak I only; it is reported in weight parts per million because this measurement is roughly equivalent to the amount of extractable hydrocarbons, which conventionally are expressed in parts per million. Also listed in table 3 is the ratio of pyrolytic hydrocarbon yield to organic carbon (PHC/OC). This ratio is analogous to the "hydrogen index" of Espitalie and others (1977), except that the numerator of our ratio is both peak I and peak II, whereas Espitalie and others (1977) used the ratio of peak II to organic carbon.

$\mathrm{PHC} / \mathrm{OC}$, expressed as percent, is sensitive to both types of organic matter and thermal maturity. That is, $\mathrm{PHC} / \mathrm{OC}$ can be low because (1) the type of organic matter originally is hydrogen-deficient and does not yield hydrocarbons upon pyrolysis, or (2) the organic matter is hydrogen-deficient because it is thermally post-mature or "overcooked" and has previously yielded hydrocarbons. Because none of these analyzed rocks are post-mature, the results can be interpreted in terms of type of organic matter, or the proportion of the total organic matter that is "live" and can be converted to hydrocarbons. In this sequence, coals and organic matter believed to be more "gas-prone" have $\mathrm{PHC} / \mathrm{OC}$ values of 10-20 percent. Potential oil source rocks should have $\mathrm{PHC} / \mathrm{OC}$ values of 30-60 percent, indicating hydrogenrich organic matter (Espitalie and others, 1977). In terms of this measurement, the Nanushuk Group and the Torok Formation are "gas-prone," as almost all values are less than 26 percent (table 3 ).

\section{Elemental Analysis}

Elemental analysis of kerogen includes values for carbon (C), hydrogen (H), nitrogen (N), and ash (table 3). Elemental analysis is also a useful indicator of "oil-prone" vs "gasprone" source rocks when values of $\mathrm{H}$ and $\mathrm{C}$ are used to derive the atomic $\mathrm{H} / \mathrm{C}$ ratio. This ratio is determined by dividing the percentage of each element in the kerogen by its atomic number $(\mathrm{H}=1.008$ and $\mathrm{C}=12.01)$, and then reducing the fraction to its decimal equivalent. If the kerogen is thermally immature and the values are greater than 1.0 , then the source rock is "oil-prone"; if the ratio is less than one, the source rock is "gas-prone" (Harwood, 1977). As "oil-prone" kerogen undergoes increased thermal alteration, the ratio decreases to a value less than 1.0 , because more hydrogen than carbon is lost with the generated and expelled hydrocarbons.

The data obtained for the Nanushuk Group and Torok Formation show ratios of less than 1.0 , or "gas-prone" source rocks. The Kukpowruk type section and Kaolak No. 1 well display a decrease in the atomic $\mathrm{H} / \mathrm{C}$ ratio with increasing depth; both start at 0.8 and decrease to about 0.6-0.7. Umiat test we11 11 remains at about 0.7. An exception to this pattern is the Topagoruk No. 1 we11, in which the atomic H/C ratio increases toward the bottom of the hole from 0.6 in the Nanushuk Group to 0.8 in the pebble shale unit, even though the vitrinite reflectance values increase substantially with depth. The increase in the atomic $\mathrm{H} / \mathrm{C}$ ratio suggests that the lower interval of the Torok Formation and the underlying pebble shale unit are richer in hydrogen, even though that part of the section is more mature.

\section{Visual Kerogen}

Rocks rich in organic matter are treated with hydrochloric and hydrofluoric acids to remove carbonate and siliceous material. The kerogen is placed on a glass slide and examined by microscope using transmitted light.. Four kerogen constituents can be identified: (1) amorphous, (2) herbaceous, (3) humic, and (4) inert. Amorphous material is algal material or sapropel of marine or lacustrine derivation and is "oil-prone." Herbaceous material includes pollen, spore and plant cuticle, or waxy materia1; it is generally considered "oil-prone" but may also contribute methane gas. Humic material constitutes the structural material of land plants and makes up a large percentage of humic coal. This constituent is "gas-prone." Inert is solid black "dead" carbon, which contributes neither oil nor gas to the hydrocarbon system. The abundance of these four constituents is visually estimated and expressed as percentages that add up to 100 percent of the material on the slide.

The visual kerogen estimates of the Nanushuk Group indicate that at least 50 percent of the constituents are herbaceous and amorphous material, or "oil-prone" source rocks (table 3, figs. 29 and 30). The woody constituent represents less than 25 percent of the total. These data appear to contradict the $\mathrm{PHC} / \mathrm{OC}$ and $\mathrm{H} / \mathrm{C}$ ratios, which suggest that these rocks are "gas-prone." If the herbaceous material is considered "gas-prone," then the three parameters agree. This apparent discrepancy warrants further investigation.

\section{INDICATORS OF THERMAL HISTORY}

\section{TAI}

As the constituents of visual kerogen are being determined, the thermal alteration index (TAI), a color variation, is observed and 
Table 3.--Organic geochemical data for the Nanushuk Group, Torok Formation, and pebble shale unit, North Slope, Alaska

[Data based on material from two outcrops and core from three wells; Sh, shale; Ss, sandstone; Co, coal; Lith, 1ithology; TAI, thermal alteration index; Mn Ro, minimum reflectance; Av Ro, average reflectance; Mx Ro, maximum reflectance; TEA-FID, thermal-evolution analysis employing a flame ionization detector; TPII ${ }^{\circ} \mathrm{C}$, absolute temperature at which a maximum occurs in the pyrolytic products of organic matter in the rock; PHC, total pyrolytic hydrocarbon yield; VHC, volatile hydrocarbon content; OC, organic carbon; Am, amorphous; Hr, herbaceous; Hu, humic; In, inert. Leaders (---) indicate that the measurement was not made]

\begin{tabular}{|c|c|c|c|c|c|c|c|c|c|c|c|c|c|c|c|c|c|c|c|c|}
\hline & & & & vitrin & ite ref 1 & ectance & & TEA-FID & & & & Elem & ental. & analys & is-kero & gen & $\underline{\text { vis }}$ & sual & kerc & ogen \\
\hline Rock Unit & $\begin{array}{l}\text { Sample No. } \\
\text { or depth (m) }\end{array}$ & Lith & TAI & Mn Ro & Av Ro & Mx Ro & $\operatorname{TpII}^{\circ} \mathrm{C}$ & PHC & VHC & $O C$ & $\mathrm{PHC} / \mathrm{OC}$ & C & H & $\mathbf{N}$ & Ash & $\frac{\mathrm{H}}{\mathrm{C}}$ & $\mathrm{Am}$ & $\mathrm{Hr}$ & $\mathrm{Hu}$ & In \\
\hline & & & & & & & KUKPOV & WRUK TY & PE SECTI & & & & & & & & & & & \\
\hline Nanushuk & 77AAHI46 & Sh & 2.2 & 0.45 & 0.68 & 0.87 & 462 & 0.11 & 298 & 1.36 & 8.09 & 72.73 & 3.88 & 1.39 & 10.30 & 0.64 & 29 & 29 & 21 & 21 \\
\hline Group & 77AAH148 & Sh & -.- & --- & --- & --- & --- & --- & $\ldots$ & 1.10 & --- & --- & -- & -.- & --- & --- & --- & --- & --- & $\cdots$ \\
\hline & 77AAH 150 & $\mathrm{Sh}$ & 2.2 & .55 & .68 & .82 & 468 & .12 & 268 & 1.56 & 7.69 & 78.07 & 4.75 & 1.67 & 6.15 & .73 & 29 & 29 & 21 & 21 \\
\hline & $77 \mathrm{AAH} 152$ & Sh & --- & --- & --- & -- & --- & --- & --- & 1.38 & --- & --- & --- & $\ldots$ & -- & --- & --- & --- & $\cdots$ & --- \\
\hline & 77AAH154 & Sh & -- & -- & --- & $\cdots$ & -- & -- & -- & 1.21 & --- & -- & -- & $-\cdots$ & --- & --- & -- & -- & -- & -- \\
\hline & 77AAH155 & Sh & -- & $\ldots$ & -- & -- & --- & -- & --- & 1.61 & --- & --- & --- & --- & $\ldots$ & --- & --- & -- & -- & $\ldots$ \\
\hline & 77AAH156B & Sh & -- & --- & --- & --- & --- & --- & -- & 1.76 & --- & -- & --- & --- & --- & --- & $-\cdots$ & -- & --- & --- \\
\hline & 77AAH159 & Sh & 2.1 & .42 & .72 & .86 & 462 & .11 & 387 & .73 & 8.03 & 64.36 & 3.92 & 4.88 & 23.54 & .73 & 8 & 33 & 25 & 33 \\
\hline & 77AAH159A & Sh & -- & --- & --- & --- & --- & -- & -- & 1.07 & -- & --- & $\cdots$ & --- & --- & -- & -- & - & -- & -- \\
\hline & 77AAHI60 & sh & 2.2 & .64 & .76 & .93 & 473 & .19 & 618 & 1.82 & 10.05 & 67.23 & 4.11 & 1.84 & 20.88 & .73 & 31 & 31 & 15 & 23 \\
\hline & 77 AAH 162 & Sh & --- & +- & -- & --- & - & --- & --- & .93 & --- & --- & -- & -- & --- & -- & -- & -- & -- & -- \\
\hline & 77AAH169 & Sh & 2.2 & .73 & .82 & .95 & 456 & .34 & 631 & 2.73 & 12.45 & 72.58 & 4.62 & 2.31 & 13.89 & .76 & 25 & 33 & 17 & 25 \\
\hline & 77AAHI 72 & Sh & 2.1 & .49 & .67 & .81 & 466 & .50 & 591 & 3.85 & 12.99 & 27.89 & 5.25 & 1.65 & 6.16 & .81 & 22 & 56 & 11 & 11 \\
\hline & 77AAH1 73 & Sh & --- & --- & -- & --- & --- & --- & $-\ldots$ & 3.28 & --- & --- & -- & --- & --- & -- & -- & -- & --- & --- \\
\hline & 77AAHI75 & Sh & -- & --- & $\cdots$ & $-\cdots$ & --- & --- & --- & 1.64 & -- & --- & --- & -- & -- & --- & -- & -- & -- & -- \\
\hline & 77 AAH 176 & Sh & 2.2 & .61 & .75 & .91 & 480 & .33 & 455 & 3.02 & 10.93 & 76.83 & 4.73 & 2.63 & 7.47 & .74 & 25 & 42 & 17 & 17 \\
\hline & 77AAHI 78 & Sh & 2.2 & .46 & .75 & .81 & 464 & 3.28 & 2,551 & 28.18 & 11.64 & 68.50 & 4.66 & 2.23 & 10.15 & .82 & 22 & 56 & 11 & 11 \\
\hline & & & & & & & BAR & ABARA & YNCLINE & & & & & & & & & & & \\
\hline Nanushuk & 77AAH183 & Sh & 2.1 & 0.43 & 0.52 & 0.66 & 453 & 0.19 & 238 & 1.95 & 9.74 & 71.74 & 4.83 & 2.13 & 1.94 & 0.81 & 0 & 42 & 33 & 25 \\
\hline Group & 77AAH186 & sh & 2.1 & .42 & .51 & .69 & 458 & .13 & 213 & 1.49 & 8.72 & 71.22 & 4.70 & 1.74 & 3.61 & .79 & 9 & 36 & 27 & 27 \\
\hline & & & & & & & & KAOLAK & NO. I WE & & & & & & & & & & & \\
\hline Nanushuk & 67 & Sh & 2.1 & 0.50 & 0.58 & 0.66 & 449 & 1.80 & 782 & 17.88 & 10.07 & 67.51 & 4.61 & 1.82 & 0.48 & 0.82 & 15 & 38 & 23 & 23 \\
\hline Group & 174 & Sh & 1.8 & .46 & .60 & .76 & 453 & .25 & 291 & 1.81 & 13.81 & 65.48 & 4.36 & 1.89 & 13.20 & .80 & 29 & 36 & 21 & 14 \\
\hline & 235 & Sh & --- & --- & -- & --- & -- & --- & -- & 3.99 & --- & --- & -- & --- & --- & -- & --- & --- & --- & -- \\
\hline & 285 & Ss & -- & -- & -- & -- & -- & -- & -- & .62 & -- & -- & --- & --- & -- & $\cdots$ & -- & --- & --- & --- \\
\hline & 302 & Sh & 1.8 & .50 & .67 & .84 & 454 & .16 & 407 & .88 & 18.18 & 47.61 & 2.58 & .70 & 38.78 & .65 & 31 & 31 & 23 & 15 \\
\hline & 305 & sh & 2.0 & .52 & .58 & .72 & 451 & 4.78 & 1,308 & 35.88 & 13.27 & 69.46 & 4.88 & 1.46 & 3.04 & .84 & 11 & 44 & 22 & 22 \\
\hline & 366 & Sh & -- & -- & -- & --- & --- & --- & --- & $61: 62$ & --- & --- & -- & --- & -- & -- & --- & $m$ & --- & -- \\
\hline & 427 & Sh & -- & --- & --- & -- & --- & --- & -- & 2.81 & --- & -- & --- & --- & --- & --- & -- & -- & --- & -- \\
\hline & 465 & Sh & 2.0 & .39 & .51 & .68 & 452 & .12 & 307 & .52 & 23.08 & 64.91 & 4.05 & 3.66 & 12.89 & .75 & 0 & 55 & 22 & 22 \\
\hline & 468 & Sh & 2.0 & .50 & .63 & .73 & 454 & 1.76 & 684 & 11.03 & 15.96 & 67.42 & 4.59 & 2.81 & 1.37 & .82 & 10 & 50 & 20 & 20 \\
\hline & 506 & Ss & --- & --- & --- & -- & -- & $-\cdots$ & $\ldots$ & .34 & -- & --- & $-\infty$ & -- & -- & -- & $\cdots$ & -- & -- & -- \\
\hline & 512 & Sh & $\cdots$ & --- & $\cdots$ & -- & --- & -- & --- & 3.62 & -- & -- & --- & --- & -- & --- & -- & --- & -- & -- \\
\hline & 556 & Sh & -- & --- & --- & -- & -- & --- & $-\cdots$ & 1.09 & --- & --- & +- & --- & --- & $\cdots$ & --- & $=-$ & -- & --- \\
\hline & 619 & $\mathrm{Sh}$ & 2.0 & .51 & .61 & .73 & 450 & 1.82 & 873 & 7.97 & 22.84 & 68.85 & 5.10 & 1.79 & 3.88 & .89 & 23 & 38 & 15 & 23 \\
\hline & 677 & Sh & -- & --- & -- & -- & -- & -- & -- & 1.37 & -- & -- & -- & --- & --- & --- & -- & $\overline{---}$ & --- & -- \\
\hline & 678 & Sh & --- & -- & -- & -- & --- & --- & --- & 12.37 & --- & --- & -- & --- & --- & $-\cdots$ & --- & -- & -- & -- \\
\hline & 735 & Sh & -- & -- & -- & --- & -- & -- & -- & 2.17 & --- & --- & -- & -- & -- & --- & --- & -- & -- & --- \\
\hline & 750 & $\mathrm{Sh}$ & 2.0 & .53 & .64 & .71 & 456 & .22 & 459 & 3.24 & 6.79 & 75.55 & 4.84 & 2.28 & 3.37 & .77 & 23 & 31 & 31 & 15 \\
\hline & 751 & Co & 2.0 & .51 & .65 & .75 & 450 & 17.90 & 12,557 & 69.79 & 25.65 & 75.81 & 5.44 & 2.47 & .74 & .86 & 0 & 22 & 33 & 44 \\
\hline & 796 & Sh & --- & $-\cdots$ & --- & -- & -- & --- & -- & 1.32 & --- & --- & --- & --- & --- & -- & --- & -- & -- & -- \\
\hline & 852 & $\mathrm{Sh}$ & --- & -- & --- & --- & --- & --- & --- & 1.26 & --- & --- & $-\cdots$ & --- & -- & $-\cdots$ & -- & -- & -- & --- \\
\hline & 899 & Sh & 2.0 & .51 & .65 & .87 & 452 & .17 & 308 & 1.08 & 15.74 & 74.60 & 4.82 & 2.47 & 6.13 & .78 & 36 & 36 & 18 & 9 \\
\hline & 963 & Ss & $--\cdot$ & --- & --- & -- & -- & $\cdots$ & -- & .93 & -- & --- & -- & -- & -- & --- & -- & -- & -- & $\cdots$ \\
\hline & 969 & Ss & --- & -- & --- & --- & --- & --- & $-\cdots$ & .40 & --- & --- & -- & -- & -- & --- & -- & -- & -- & -- \\
\hline & 994 & Ss & -- & --- & --- & -- & -- & --- & -- & 1.03 & --- & --- & -- & --- & -- & --- & --- & -- & -- & --- \\
\hline & 1,059 & Sh & 2.0 & .42 & .71 & .93 & 454 & .12 & 270 & .60 & 20.00 & 72.01 & 4.07 & 1.15 & 9.57 & .68 & 0 & 36 & 27 & 36 \\
\hline & 1,119 & Sh & --- & $-\cdots$ & -- & --- & $\cdots$ & -- & -- & 1.41 & --- & --- & --- & --- & -- & --- & -- & --- & $\cdots$ & --- \\
\hline & 1,183 & Sh & -- & -- & -- & -- & $\cdots$ & --- & --- & 1.74 & --- & --- & $\cdots$ & -- & --- & $-\cdots$ & --- & $=-$ & -- & --- \\
\hline & 1,219 & Sh & --- & $\cdots$ & --- & -- & --- & --- & --- & 38.82 & -- & --- & --- & $\cdots$ & --- & --- & -- & --- & -- & $m$ \\
\hline & 1,225 & $\mathrm{sh}$ & 2.1 & .65 & .74 & .82 & 457 & 1.16 & 829 & 6.52 & 17.79 & 71.45 & 4.57 & 2.60 & 10.21 & .77 & 17 & 42 & 25 & 17 \\
\hline & 1,245 & Ss & -- & --- & -- & --- & --- & --- & --- & .25 & -- & -- & --- & $\cdots$ & --- & --- & $\cdots$ & -- & -- & -- \\
\hline Torot & 1,248 & sh & --- & -- & --- & --- & --- & --- & -- & 1.02 & --- & --- & $-\cdots$ & --- & --- & --- & --- & --- & --- & -- \\
\hline r'ormation & 1,273 & $\mathrm{Sh}$ & --- & --- & -- & $\ldots$ & -... & -.- & --- & .65 & --- & --- & -- & --- & --- & -- & --- & -- & -- & -- \\
\hline & 1,274 & co & -- & -- & --- & --- & --- & --- & $\cdots$ & 65.18 & -- & -- & -- & --- & --- & --- & -- & --- & -- & -- \\
\hline & 1,353 & $\mathrm{Sh}$ & -- & --- & -- & $\ldots$ & --- & --- & --- & 1.11 & --- & --- & --- & --- & --- & -- & --- & -- & -- & --- \\
\hline & 1,411 & Sh & -- & --- & --- & --- & -- & -- & -- & 1.55 & -- & --- & -- & --- & --- & -- & --- & --- & -- & -- \\
\hline & 1,469 & Sh & 2.1 & .71 & .86 & 1.01 & 464 & .88 & 1,157 & 4.40 & 20.00 & 77.29 & 4.83 & 2.13 & $5: 96$ & .75 & 11 & 56 & 22 & 11 \\
\hline & 1,475 & Sh & 2.1 & .74 & .86 & .98 & 468 & 4.16 & 4,912 & 18.15 & 22.92 & 71.36 & 4.78 & 2.29 & 8.13 & .80 & 10 & 40 & 30 & 20 \\
\hline & 1,481 & Sh & --- & -- & -- & -- & --- & -- & - & 1.25 & --- & --- & --- & -- & $\cdots$ & --- & -- & --- & --- & --- \\
\hline & 1,548 & Sh & --- & --- & -- & --- & -- & $-\cdots$ & --- & 1.41 & -- & --- & --- & -- & -- & --- & --- & -- & $-\infty$ & --- \\
\hline & 1,554 & $\mathrm{Sh}$ & --- & -- & --- & -- & --- & --- & --- & 1.12 & -- & --- & --- & -- & --- & --- & -- & -- & --- & --- \\
\hline & 1,612 & Sh & $\cdots$ & --- & -- & --- & -- & --- & --- & 1.21 & --- & --- & $\rightarrow$ & -- & --- & --- & $-\cdots$ & --- & -- & --- \\
\hline & 1,673 & $\mathrm{sh}$ & 2.2 & .71 & .86 & 1.08 & 475 & .57 & 1,075 & 2.95 & 19.32 & 81.86 & 5.13 & 2.53 & 2.71 & .75 & 11 & 56 & 22 & 11 \\
\hline & 1,722 & Sh & -- & -- & --- & -- & -- & -- & -.- & 1.53 & -- & -- & -- & -- & -- & -- & -- & --- & -- & -- \\
\hline & 1,754 & Sh & --- & --- & --- & --- & -- & -- & $\ldots$ & 1.28 & --- & --- & -- & --- & --- & -.- & --- & -- & --- & -+ \\
\hline & 1,807 & Sh & -- & --- & --- & --- & -- & --. & -- & 2.78 & --- & --- & --- & --- & --- & --- & -- & --- & --- & -- \\
\hline & 1,868 & $\mathrm{Sh}$ & 2.2 & .79 & 1.08 & 1.33 & 464 & .15 & 456 & 1.27 & 11.81 & 70.68 & 3.93 & 2.10 & 15.98 & .67 & 0 & 45 & 27 & 27 \\
\hline & 1,942 & Ss & -- & --- & -- & -- & -- & -- & --- & .19 & -- & -- & $\cdots$ & -- & - & -- & -- & -- & - & - \\
\hline & 1,947 & Ss & -- & --- & -- & --- & -- & -- & -- & 1.15 & --- & -- & --- & --- & --- & -- & -- & --- & --- & -- \\
\hline & 1,957 & Sh & $-\cdots$ & --- & --- & --- & --- & --- & --- & 1.35 & --- & --- & --- & --- & --- & -- & --- & --- & --- & --- \\
\hline & 2,010 & $\mathrm{Sh}$ & -- & --- & --- & --- & --- & --- & --- & 1.68 & --- & --- & --- & --- & -- & -- & --- & $\cdots$ & --- & -- \\
\hline & 2,057 & Ss & --- & --- & --- & --- & --- & -- & $\ldots$ & .31 & -- & --- & --- & -- & --- & --- & --- & --- & --- & --- \\
\hline & 2,059 & Sh & 2.2 & .95 & 1.15 & 1.29 & 482 & .11 & 344 & 1.06 & 10.38 & 70.59 & 3.95 & 2.62 & 19.43 & .67 & 0 & 45 & 27 & 27 \\
\hline
\end{tabular}


Table 3.--Organic geochemical data for the Nanushuk Group, Torok Formation, and pebble shale unit, North Slope, Alaska--Continued

\begin{tabular}{|c|c|c|c|c|c|c|c|c|c|c|c|c|c|c|c|c|c|c|c|c|}
\hline \multirow[b]{2}{*}{ Rock unit } & \multirow[b]{2}{*}{$\begin{array}{l}\text { Sample No. } \\
\text { or depth (m) }\end{array}$} & \multirow[b]{2}{*}{ Lith } & \multirow[b]{2}{*}{ TAI } & Vitrini & te ref 1 & ectance & & EA-F ID & & & & Elem & ental. & analys & is-kero & gen & $\underline{\text { Vis }}$ & sual & kers & ggen \\
\hline & & & & $M_{n}$ Ro & Av Ro & Mx Ro & $\mathrm{TpII}^{\circ} \mathrm{C}$ & PHC & VHC & OC & PHC/OC & $\mathrm{C}$ & H & $\mathbf{N}$ & Ash & $\frac{\mathrm{H}}{\mathrm{C}}$ & $\mathrm{Am}$ & $\mathrm{Hr}$ & $\mathrm{Hu}$ & In \\
\hline & & & & & & & & PAGORUI & $0.1 \mathrm{k}$ & & & & & & & & & & & \\
\hline Nanushuk & 278 & Sh & 2.0 & 0.33 & 0.41 & 0.56 & 473 & 0.23 & 114 & 2.01 & 11.44 & --- & -- & --- & --- & --- & 0 & 50 & 13 & 37 \\
\hline Group & 366 & Sh & 1.8 & - & -- & -- & 468 & .11 & 216 & .85 & 12.94 & 69.47 & 3.63 & 2.91 & 7.63 & 0.63 & 0 & 63 & 25 & 13 \\
\hline & 457 & Sh & 1.8 & .39 & .49 & .59 & 468 & .18 & 299 & 1.27 & 14.17 & 56.30 & 3.08 & 1.15 & 25.39 & .66 & 0 & 63 & 13 & 25 \\
\hline & 547 & $\mathrm{Sh}$ & 1.8 & - & -- & -- & 459 & .08 & 304 & .80 & 10.00 & 66.54 & 2.83 & 1.24 & 15.76 & .51 & 0 & 56 & 11 & 33 \\
\hline & 637 & Sh & 1.8 & .35 & .47 & .59 & 458 & .12 & 322 & 1.08 & 11.11 & 63.30 & 3.27 & 1.24 & 18.26 & .62 & 33 & 42 & 17 & 8 \\
\hline Torok & 728 & $\mathrm{Sh}$ & 2.1 & .35 & .50 & .68 & 472 & .10 & 109 & 1.14 & 8.77 & 50.91 & 3.03 & 3.97 & 34.48 & .71 & 0 & 44 & 11 & 45 \\
\hline Formation & 805 & Sh & 1.9 & -- & --- & -- & 467 & .15 & 402 & 1.13 & 13.27 & 70.49 & 3.74 & 1.49 & 9.17 & .64 & 17 & 42 & 25 & 17 \\
\hline & 896 & Sh & 1.9 & .34 & .49 & .59 & 476 & .17 & 347 & 2.44 & 6.97 & 71.57 & 4.01 & 1.50 & 7.99 & .67 & 0 & 63 & 25 & 13 \\
\hline & 988 & Sh & 2.1 & .38 & .57 & .79 & 470 & .10 & 96 & 1.10 & 9.09 & 10.83 & 1.17 & 3.28 & 74.42 & 1.30 & 44 & 33 & 0 & 23 \\
\hline & 1,085 & Sh & 2.0 & .39 & .56 & .63 & 465 & .19 & 442 & .38 & 50.00 & 73.63 & 4.29 & 1.75 & 8.33 & .70 & 30 & 50 & 10 & 10 \\
\hline & 1,250 & Sh & 2.1 & .32 & .52 & .65 & 477 & .15 & 270 & 1.25 & 12.00 & 69.25 & 4.49 & 2.10 & 7.84 & .78 & 0 & 44 & 11 & 45 \\
\hline & 1,493 & Sh & 2.1 & .38 & .69 & .85 & 479 & .17 & 228 & 1.27 & 13.39 & 52.00 & 3.67 & 3.34 & 23.54 & .85 & 0 & 50 & 12 & 38 \\
\hline & 1,526 & $\mathrm{Sh}$ & 2.0 & $-\cdots$ & -- & -- & 477 & .09 & 214 & 1.08 & 8.33 & 60.34 & 3.25 & 1.03 & 23.92 & .65 & 0 & 63 & 13 & 25 \\
\hline & 1,553 & Sh & 2.0 & --- & --- & -- & 466 & .14 & 364 & 1.10 & 12.73 & 60.23 & 3.33 & 8.71 & 26.00 & .66 & 0 & 63 & 13 & 25 \\
\hline & 1,580 & Sh & 2.0 & --- & -- & --- & 470 & .17 & 327 & 1.13 & 15.04 & 80.25 & 5.16 & 2.96 & 3.66 & .77 & 0 & 71 & 14 & 14 \\
\hline & 1,634 & Sh & 2.1 & .54 & .75 & .87 & 478 & .15 & 298 & 1.29 & 11.63 & 76.75 & 3.89 & 1.04 & 7.43 & .61 & 0 & 50 & 30 & 20 \\
\hline & 1,670 & $\mathrm{Sh}$ & 2.1 & -- & -- & $\ldots$ & 478 & .14 & 352 & 1.03 & 13.59 & 76.10 & 4.60 & 2.76 & 8.37 & .73 & 0 & 50 & 20 & 30 \\
\hline & $1,69 ?$ & $\mathrm{Sh}$ & 2.1 & --- & --- & --- & 475 & .14 & 345 & 1.11 & 12.61 & 74.08 & 3.92 & 1.24 & 11.00 & .63 & 0 & 56 & 11 & 33 \\
\hline & 1,733 & Sh & 2.1 & .59 & .77 & .88 & 475 & .19 & 449 & 1.15 & 16.52 & 73.00 & 4.40 & .04 & 12.63 & .72 & 0 & 50 & 20 & 30 \\
\hline & 1,768 & Sh & 2.2 & $\ldots$ & -- & --- & 480 & .15 & 303 & 1.23 & 12.20 & 70.67 & 4.00 & 2.49 & 17.12 & .68 & 0 & 45 & 27 & 27 \\
\hline & 1,788 & Sh & 2.2 & -- & -- & --- & 484 & .16 & 374 & 1.58 & 10.13 & 80.54 & 4.63 & 1.50 & 4.97 & .69 & 31 & 38 & 15 & 15 \\
\hline & 1,814 & Sh & 2.2 & $-\infty$ & -- & --- & 481 & .15 & 426 & .93 & 16.13 & 68.11 & 4.44 & 7.68 & 17.36 & .78 & 0 & 45 & 18 & 36 \\
\hline & 1,820 & Ss & -- & -- & -- & --- & -.. & -- & -- & 1.13 & --- & $-\ldots$ & --- & $--\infty$ & --- & --- & --- & $-\infty$ & $\cdots$ & -- \\
\hline & 1,830 & Sh & 2.2 & --- & --- & --- & 483 & .13 & 247 & 1.23 & 10.57 &.- & -- & --- & --- & --- & 0 & 45 & 27 & 27 \\
\hline & 1,836 & Sh & 2.2 & .45 & .75 & .96 & 490 & .14 & 267 & 1.10 & 12.73 & --- & -- & -- & --- & --- & 0 & 44 & 22 & 34 \\
\hline & 1,875 & $\mathrm{Sh}$ & 2.2 & -.- & -.- & --- & 488 & .15 & 380 & 1.31 & 11.45 & 70.34 & 4.27 & 1.22 & 12.26 & .73 & 40 & 40 & 10 & 10 \\
\hline & 1,981 & $\mathrm{sh}$ & 2.2 & .58 & .79 & .94 & 484 & .14 & 406 & 1.12 & 12.50 & 80.48 & 4.58 & 1.40 & 4.21 & .68 & 0 & 27 & 36 & 36 \\
\hline Pebble & 2,057 & Sh & 2.2 & --- & --- & --- & 478 & .17 & 579 & 1.92 & 8.85 & 66.53 & 3.66 & 6.18 & 19.83 & .66 & 0 & 40 & 20 & 40 \\
\hline shale unit & 2,088 & $\mathrm{Sh}$ & 2.2 & --- & -- & $\ldots$ & 484 & .40 & 502 & 2.98 & 13.42 & 75.01 & 4.86 & 2.53 & 10.96 & .78 & 44 & 44 & 11 & 0 \\
\hline & 2,146 & Sh & 2.2 & .54 & .79 & 1.07 & 483 & .19 & 396 & 1.70 & 11.18 & --- & -- & $\cdots$ & $\ldots$ & --- & .0 & 57 & 0 & 43 \\
\hline & 2,379 & Sh & 2.4 & .53 & .73 & .97 & 471 & .06 & 243 & .87 & 6.90 & 56.21 & 3.56 & 11.59 & 28.06 & .76 & 44 & 22 & 11 & 22 \\
\hline & 2,390 & Sh & 2.4 & & & & 471 & .03 & 152 & .20 & 15.00 & & & & & & 40 & 20 & 10 & 30 \\
\hline & & & & & & & & MIAT T' & WELL & & & & & & & & & & & \\
\hline Colville & 76 & Sh & --- & $\ldots$ & --- & --- & --- &.- & --- & 0.33 & --- & --- & -- & $\cdots$ & -- & -- & -- & --- & -- & -- \\
\hline Group & 85 & Sh & --- & - & --- & --- & --- & -- & --- & 1.18 & $\ldots$ & -..- & $\ldots$ & -.- & -.- & --- & $\cdots$ & --- & --- & -- \\
\hline & 105 & Sh & --- & -- & --- & $-\cdots$ & -- & --- & --- & 1.14 & --- & --- & --- & --- & --- & -- & --- & --- & --- & --- \\
\hline & 106 & $\mathrm{Co}$ & --- & --- & --- & --- & --- & --- & --- & 48.98 & --- & -- & --- & --- & --- & -- & -- & --- & --- & --- \\
\hline & 120 & $\mathrm{Co}$ & --- & -- & --- & -- & --- & --- & --- & 17.89 & -- & --- & --- & $-\ldots$ & -- & --- & --- & --- & --- & --- \\
\hline & 143 & $\mathrm{sh}$ & -- & --- & -- & --- & --- & --- & --- & .93 & --- & ... & --- & --- & $\cdots$ & -- & --- & $\ldots$ & --- & -- \\
\hline & 144 & Co & -- & -+- & -- & --- & --- & -- & --- & 41.60 & -- & --- & --- & -- & -- & --- & -- & -- & --- & -- \\
\hline & 149 & $\mathrm{Sh}$ & --- & --- & -- & -- & -- & --- & --- & .28 & --- & --- & --- & -- & -- & --- & --- & --- & --- & --- \\
\hline & 155 & sh & --- & --- & --- & -- & --- & --- & --- & .35 & --- & --- & --- & -- & --- & --- & -- & --- & --- & --- \\
\hline & 164 & Ss & --- & --- & --- & --- & --- & $\ldots$ & --- & .22 & --- & --- & -.- & $\cdots$ & $\ldots$ & --- & $-\infty$ & $-\ldots$ & --- & --- \\
\hline & 165 & Sh & --- & --- & --- & --- & --- & --- & -- & .74 & --- & --- & --- & --- & --- & -- & -- & --- & --- & -- \\
\hline & 171 & Sh & 1.9 & .32 & .40 & .54 & 444 & .14 & 532 & .98 & 14.29 & 61.71 & 3.56 & 1.31 & 12.39 & .69 & 15 & 38 & 23 & 23 \\
\hline & 219 & Sh & -- & $\ldots$ & --- & -- & -- & $\ldots$ & --- & 1.31 & $\ldots$ & -- & -- & -- & -- & -- & $\ldots$ & -- & -- &.- \\
\hline & 238 & $\mathrm{Sh}$ & --- & -- & - - & --- & --- & --- & -- & .82 & --- & -.- & --- & --- & --- & -- & --- & --- & -- & -- \\
\hline & 247 & $\mathrm{Sh}$ & 1.9 & .38 & .42 & .53 & 444 & .09 & 438 & .60 & 15.00 & 64.46 & 3.48 & 1.96 & 12.00 & .65 & 8 & 25 & 33 & 33 \\
\hline & 309 & $\mathrm{Sh}$ & --- & -- & -- & -- & -- & -- & -- & .79 & -- & -- & --- & --- & --- & --- & --- & --- & --- & --- \\
\hline & 315 & Sh & $-\cdots$ & --- & --- & --- & -- & --- & --- & .99 & -- & -- & --- & --- & --- & --- & --- & $-\ldots$ & --- & --- \\
\hline & 375 & Sh & 2.0 & .38 & .47 & .53 & 441 & .06 & 284 & .69 & 8.70 & 63.72 & 3.28 & 2.88 & 14.69 & .62 & 0 & 27 & 36 & 36 \\
\hline & 511 & $\mathrm{Sh}$ & 2.0 & .30 & .42 & .55 & 447 & .10 & 311 & .87 & 11.49 & 67.27 & 4.21 & 2.23 & 9.38 & .75 & 25 & 33 & 25 & 17 \\
\hline & 597 & $\mathrm{Sh}$ & 2.0 & .37 & .48 & .56 & 450 & .06 & 130 & .59 & 10.17 & 44.07 & 2.76 & 1.03 & 38.57 & .75 & 0 & 36 & 27 & 36 \\
\hline Nanushuk & 634 & Sh & -- & --- & -- & --- & --- & $\ldots$ & --- & .96 & --- & -- & -- & --- & $\ldots$ & --- & --- & --- & --- & --- \\
\hline Group & 646 & Ss & --- & --- & --- & $\ldots$ & --- & -.- & -- & .32 & --- & $\ldots$ & --- & --- & --- & -.. & --- & $-\ldots$ & --- & --- \\
\hline & 658 & $\mathrm{Sh}$ & -.- & --- & --- & --- & --- & -- &.- & 2.18 & -- & --- & --- & --- & --- & -- & -.. & --- & -- & $\ldots$ \\
\hline & 664 & Sh & --- & --- & -- & --- & --- & --- & --- & .97 & --- & --- & --- & --- & --- & --- & --- & --- & --- & --- \\
\hline & 671 & Sh & -- & -- & -- & -- & -- & --- & -- & 3.46 & -- & $-\cdots$ &.- & --- & -- & -- & -- & --- & -- & -- \\
\hline & 677 & $\mathrm{Sh}$ & 2.1 & .32 & .46 & .57 & 447 & .13 & 265 & 1.27 & 10.24 & 69.55 & 4.36 & 1.34 & 9.81 & .75 & 25 & 42 & 17 & 17 \\
\hline & 684 & Sh & --- & -- & $-\ldots$ & --- & -- & -- & $\ldots$ & 1.80 & -- & -- & -- & -- & -- & $\cdots$ & -- & --- & -- & --- \\
\hline & 701 & Ss & --- & --- & --- & --- & --- & -- & -- & .43 & --- & --- & --- & -- & --- & $-\cdots$ & --- & -- & $-\infty$ & --- \\
\hline Torok & 707 & Sh & -- & --- & --- & --- & --- & --- & -- & .84 & -- & --- & --- & $-\ldots$ & -.. & $--\infty$ & --- & $-\infty$ & -- & --- \\
\hline Formation & 732 & Sh & 2.1 & .31 & .42 & .59 & 450 & .19 & 428 & 1.41 & 16.67 & 70.95 & 4.20 & 2.11 & 7.17 & .71 & 0 & 40 & 20 & 40 \\
\hline & 823 & Sh & 2.1 & .40 & .49 & .57 & 452 & .15 & 403 & .91 & 16.48 & -- & -- & -- & -- & --- & 0 & 40 & 20 & 40 \\
\hline & 829 & $\mathrm{Sh}$ & 2.1 & .40 & .54 & .61 & 452 & .17 & 474 & 1.11 & 15.32 & --- & $\ldots$ & --- & --- & -- & 0 & 36 & 36 & 27 \\
\hline & 895 & $\mathrm{Sh}$ & --- & --- & --- & - & --- & -- & -- & 4.06 & --- & --- & -- & --- & --- & --- & --- & $-\ldots$ & $-\rightarrow$ & -- \\
\hline & 1,015 & Sh & 2.2 & .37 & .53 & .66 & 452 & .22 & 434 & 1.66 & 13.25 & 74.41 & 4.26 & 2.01 & 4.94 & .69 & 8 & 42 & 25 & 25 \\
\hline
\end{tabular}

subjectively measured against a standard on a scale from 1 to 5 (table 3 ). Kerogen coloration ranges from a pale yellow (1) to black (5), with 2 to 4 being the mid-range. The TAI for the four sections varies between 1.8 and 2.4 , a rather small range when compared to the vitrinite reflectance values. There is, however, a slight increase in TAI down section, as would be expected with increasing temperature or depth of burial. 


\title{
KUKPOWRUK \\ TYPE SECTION
}

SEC. 22, T. 2 S., R. 45 W.

MEASURED SECTION
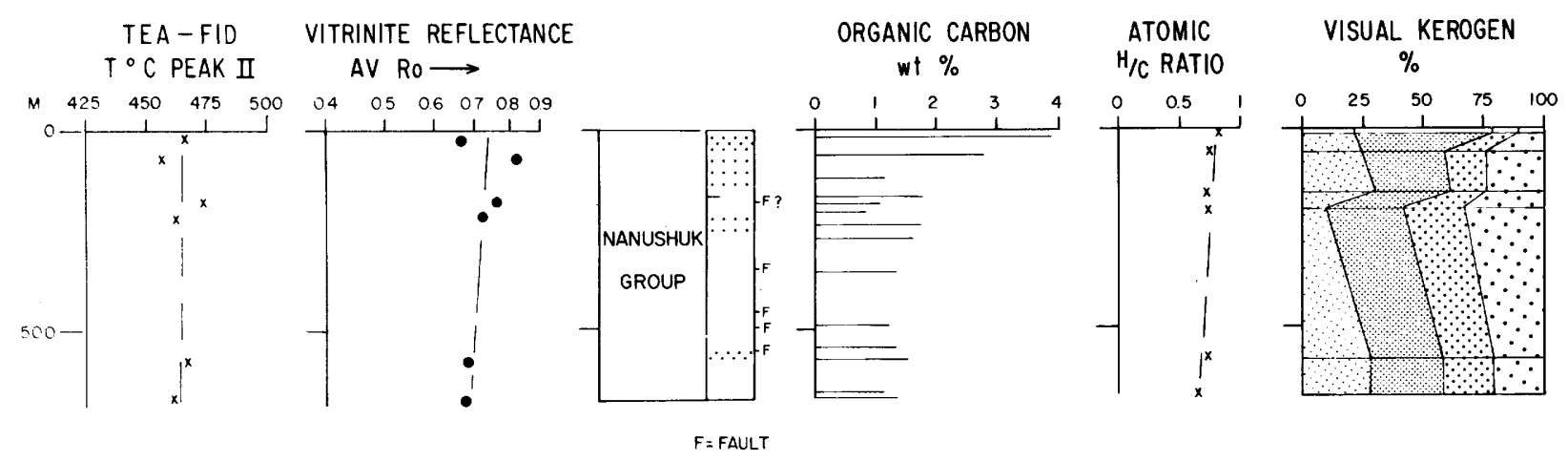

\section{KAOLAK NO. 1 WELL}

\author{
SEC. 25, T.7N., R.34 W. \\ ELEV. $54 \mathrm{~m}$ K.B.
}

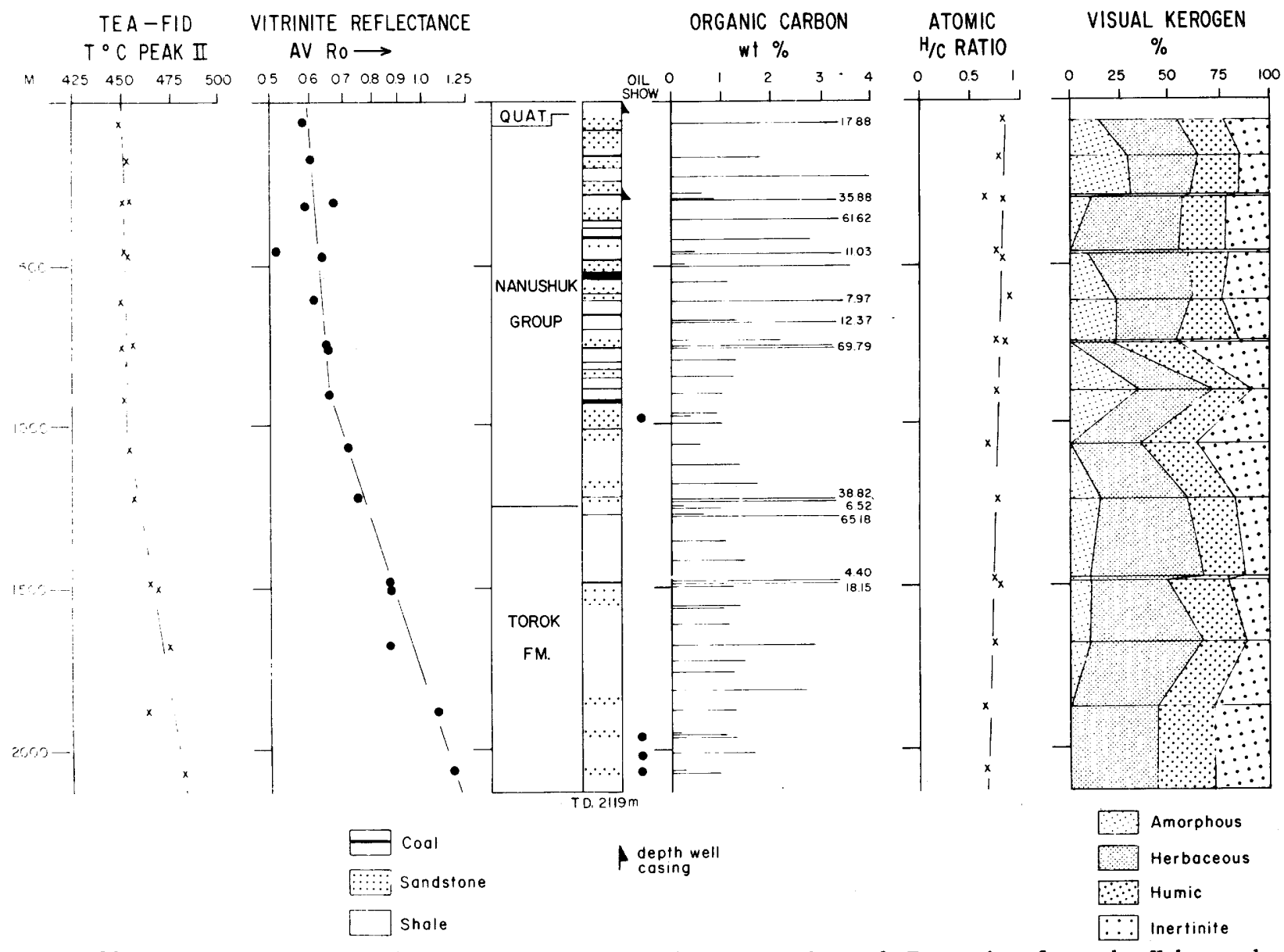

Figure 29.--Organic geochemical data for the Nanushuk Group and Torok Formation from the Kukpowruk type section and Kaolak No. 1 well. 


\section{TOPAGORUK NO.1 WELL}

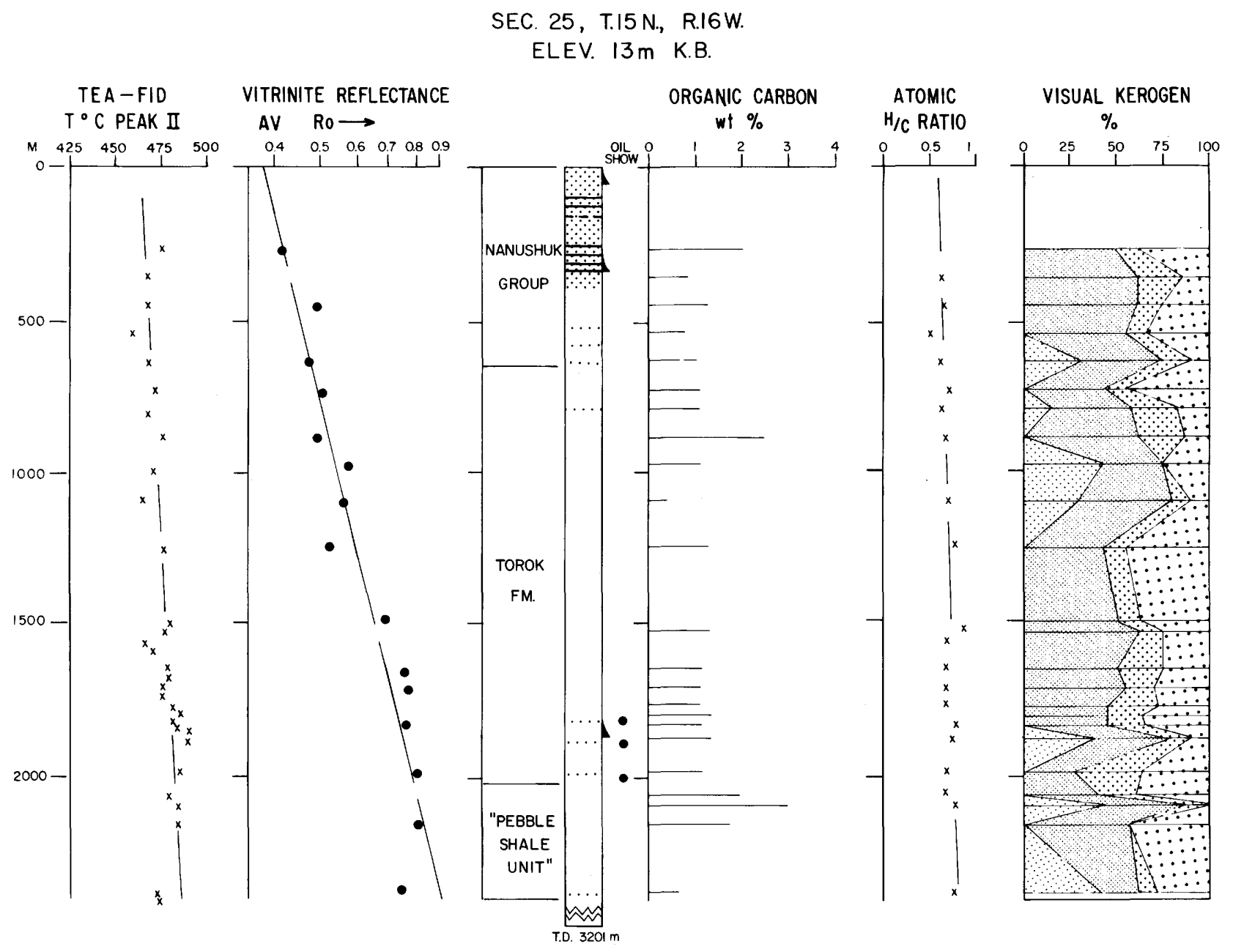

\section{UMIAT TEST WELL 11}

SEC. 27, T.I N., R.IW.

ELEV. $147 \mathrm{~m}$ K.B

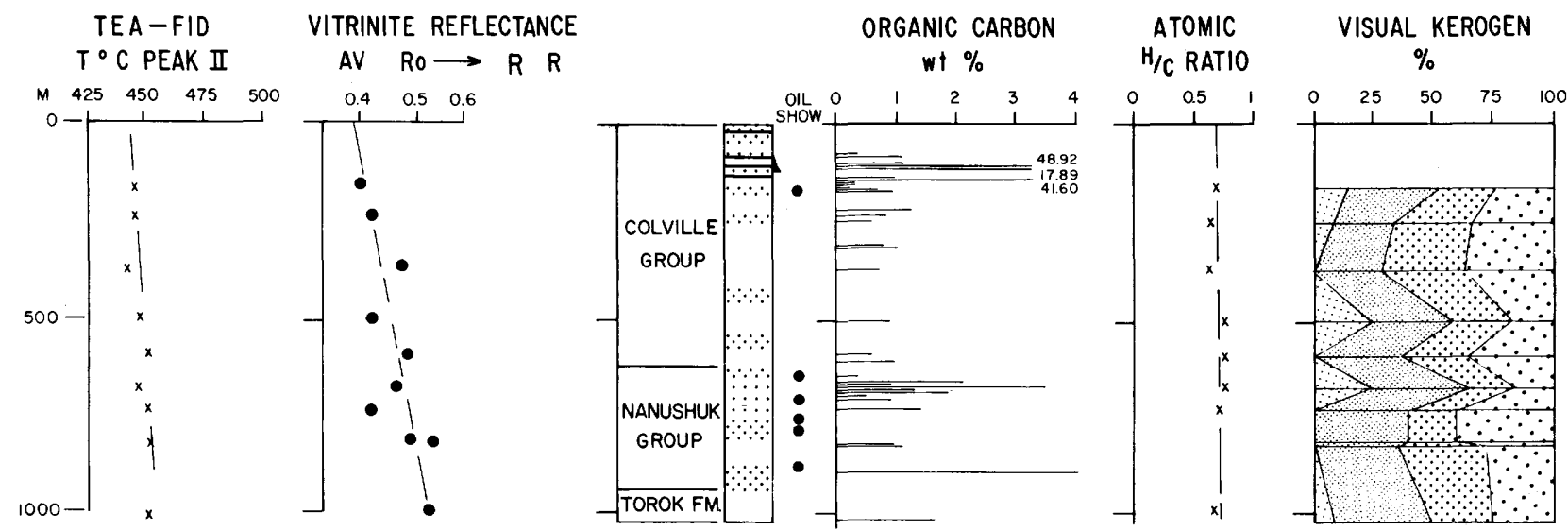

Figure 30.--Organic geochemical data for the Colville and Nanushuk Groups, Torok Formation, and pebble shale unit from the Topagoruk No. 1 well and Umiat test well 11. 
TEA-FID

The second peak from the thermal analysis can be used empirically as an indicator of thermal history (table 3, figs. 29 and 30). Theoretically, the maximum temperature in degrees Centigrade of the second peak increases in proportion to the degree of burial heating experienced by the organic matter in the subsurface. Interpretation of maturity based on the temperature of maximum pyrolysis yield is not well established. In general, temperatures $\left(\mathrm{TpII}{ }^{\circ} \mathrm{C}\right.$ ) below $460^{\circ} \mathrm{C}$ suggest thermal immaturity and above $480^{\circ} \mathrm{C}$ suggest maturity (Claypool and others, 1977).

With the exception of the Kukpowruk type section, which shows a slight lowering of temperature with depth, the temperature of maximum pyrolysis yield, or peak II, increases with depth and approaches $475^{\circ} \mathrm{C}$ in all wells. Umiat test we11 11 approaches $450^{\circ} \mathrm{C}$ at total depth and represents the coolest temperature history of the four sections studied. Kaolak No. 1 well also records a low temperature history, while the Topagoruk No. 1 well and Kukpowruk type section record a higher temperature history. Using the criterion of $480^{\circ} \mathrm{C}$ for maturity, these rocks approach but do not reach maturity.

\section{Vitrinite Reflectance}

Rocks containing organic matter are treated with acids to remove non-organic material, washed, molded into a cylinder, and mounted in a plastic plug for polishing. The polished surface is observed by microscope under reflected light. Vitrinite, a type of coaly particle, is identified and the percentage of reflected light measured. As many as 50 reflectance readings for each sample are acquired. Minimum, average, and maximum reflectance values are reported (table 3 ). The average values are plotted and a straight line is visually fitted to them (figs. 29 and 30 ).

With the exception of the Kukpowruk type section, the average reflectance values increase with depth. The reflectance values are greater in the west than in the central North Slope or eastern part of NPRA, suggesting more uplift on the west. The gradients of the reflectance values are similar for the Topagoruk No. 1 well and Umiat test well 11, but not for the Kaolak No. 1 well. This well has a "dog 1 eg" at 1,000 $m$ for both the reflectance and TEA-FID data, suggesting a decrease in the geothermal gradient in the west during the time of deposition of the middle part of the Nanushuk Group. None of the other wells or outcrop, however, expresses this change in geothermal gradient.

General criteria for the threshold of maturity for vitrinite reflectance varies with authors (Dow, 1977b; Hood and others, 1975), but ranges from 0.5 to 0.65 . With the exception of Umiat test well 11, all wells and the outcrop within the Nanushuk Group meet this criterion for thermal maturity. In Umiat test well 11, the 0.5 value lies just beneath the Nanushuk in the uppermost Torok Formation. Caution must be exercised in using this and other parameters of maturity discussed here (TAI, TEA-FID) as none have been calibrated for this basin by comparison with the hydrocarbons extracted from the rocks. Until this calibration is completed, these indices of maturity are empirical. In conclusion, on the basis of empirical use of vitrinite-reflectance data, the Nanushuk Group is mature in the western and immature in the central part of the North Slope.

\section{CONCLUSIONS}

Preliminary analytical work completed for the Kukpowruk outcrop section and Kaolak No. 1 we11, Topagoruk No. 1 well, and Umiat test well 11 in the Nanushuk Group and Torok Formation suggests that the rocks rich in organic matter are hydrocarbon source rocks and are more likely to generate methane gas than oil. The thermal history of the Nanushuk Group in the western North Slope may have been hotter than in the central North Slope as the rocks have higher reflectance and TAI values. The Nanushuk Group in the west is mature, whereas the rocks in the Topagoruk No. 1 well and Umiat test well 11 are immature. Oil in sandstones of the Nanushuk Group in Umiat oil field migrated from hotter, deeper strata, as the shales encasing the sandstone are immature. 
TEXTURAL AND MINERALOGICAL STUDY OF

SOME SURFACE AND SUBSURFACE SANDSTONES FROM

THE NANUSHUK GROUP, WESTERN NORTH SLOPE, ALASKA

By Susan Bartsch-Winkler

\section{INTRODUCTION}

Twenty-one surface and forty-five subsurface samples of sandstone from the Lower and Upper Cretaceous Nanushuk Group were examined in thin section in order to determine the textural and mineralogical factors that might affect reservoir characteristics. The surface samples were collected by James Fox in July 1975 from scattered outcrops of the Nanushuk Group (fig. 31); their relative stratigraphic positions are uncertain. The subsurface samples were obtained from cores stored at the U.S. Geological Survey warehouse in Fairbanks and from "perm plugs" used to determine porosity and permeability; their relative stratigraphic positions are wel1 known (Robinson, 1956, 1958, 1959a, b, c, 1964; Collins, 1958b, c, 1959).

No previous petrographic study has been conducted on the surface and subsurface samples reported herein, but Krynine (1947, 1948), Krynine and Ferm (1952), and Fox and others (1979) studied rocks from the Umiat test wells. Their descriptions and analyses served as excellent and invaluable introductions to the complexities and nuances of the Nanushuk Group.

The use of the cathodoluminiscope and the able assistance of Eve S. Sprunt, Stanford University, are gratefully acknowledged.

\section{METHODS}

The thin sections were stained with sodium cobaltinitrite to aid in identifying potassium feldspar and injected with blue plastic to enhance the pores; 300 grains were counted per section. Whole rock X-ray studies were conducted by Paul D. Blackmon and Harry C. Starkey, U.S. Geological Survey, Denver, to identify clay types and major mineral constituents. Polished thin sections of selected samples were examined under cathodoluminescent light in order to determine cement relationships and possible grain overgrowths. Rock chips from the surface samples were coated with goldpalladium and were examined using a Cambridge 180 scanning electron microscope with an attached electron-dispersive X-ray-analyzer to further study the relationships between grains, pores, and cements. Using the petrographic microscope, textural parameters were determined by estimation and measurement of sorting, packing density, and percent matrix.

\section{TEXTURE}

The surface samples, and presumably the subsurface samples, were collected from a wide variety of depositional environments, including fluvial-point-bar and channel, prodelta, deltafront, shallow-marine, and marine sandstones; and thus various stages and types of weathering, cementation, alteration, sorting, and bed types are represented in these samples. The samples have been grouped into surface and subsurface samples, and further grouped according to map location to help distinguish compositional differences in the rocks. Surface samples east of long $156^{\circ} \mathrm{W}$. are numbered from 1075 to 3075 ; those west, from 3275 to 5475. Subsurface samples in the eastern suite (east of long $155^{\circ}$ W.) include samples from Square Lake, Titaluk, Knifeblade, Wolf Creek, Gubik, and Grandstand test wells; subsurface samples in the western suite are from Simpson, Topagoruk, Meade, Oumalik, and Kaolak test wells.

Textural properties of the surface and subsurface sandstones are shown in figure 32 (Winkler and others, 1976, p. 8-12). Generally, the most favorable reservoir characteristics for each textural category are shown toward the right side of the abscissa; the least favorable are shown toward the left side. The ordinate is the percent of total samples exhibiting the particular property indicated. Sorting was estimated by referring to sorting images illustrated by Pettijohn, Potter, and Siever (1972, p. 585). Estimated packing density was determined visually using these criteria: "high"--framework grains tightly packed with abundant penetration involving squeezing of relatively soft lithic fragments between and around more resistant grains such as quartz and feldspar; "moderate"--closely packed framework with minor grain interpenetration and little or no deformation of 1ithic fragments; and "1ow"-framework separated by or floating in matrix or 


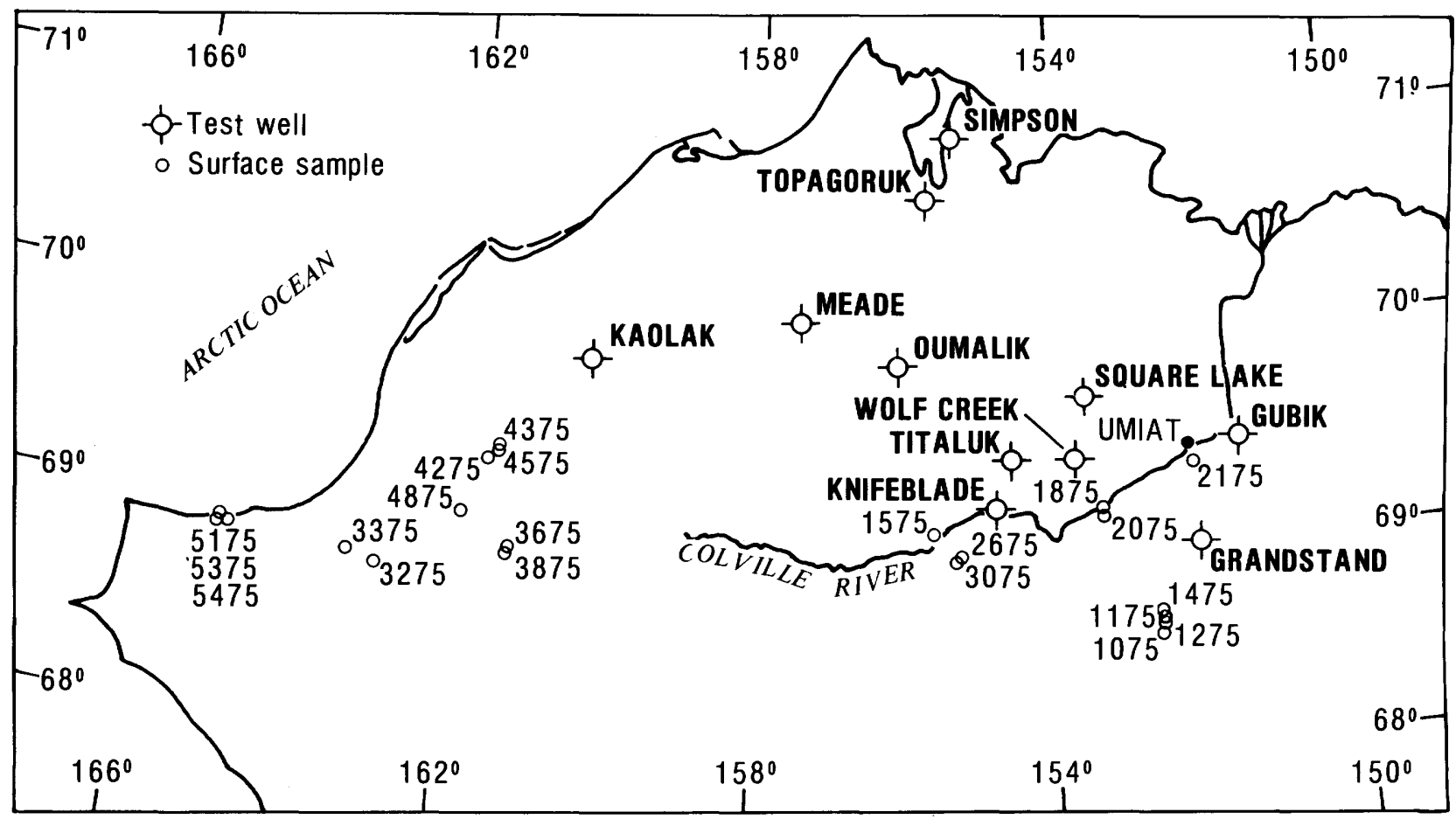

Figure 31.--Index map showing location of test we1ls and surface-sample localities. Twenty-one surface samples and forty-five subsurface samples of sandstones of the Lower and Upper Cretaceous Nanushuk Group were studied.

authigenic cement with no observable grain interpenetration. Type of grain contacts (Taylor, 1950) include (1) sutured grains, mutual stylolitic interpenetration of two or more grains (which must be carefully distinguished from grains of polycrystalline quartz), usually attributed to much pressure solution; (2) concavo-convex grain contacts, attributed to moderate pressure solution; (3) long or straight contacts, indicative of only minor compaction and pressure solution; (4) point or tangential contacts, having minor or no pressure solution; and (5) floating grains, which are not in contact with other framework constituents. Most samples exhibit more than one type of common grain contact. Textural components and cement + matrix were determined from the modal analysis of each thin section. Matrix (as discussed by Dickinson, 1970) may be high in samples having significant amounts of phyllosilicate coatings and (or) "squeezed" or "compacted" 1ithic fragments. Data from which figure 32 was derived are shown in appendix 1. Maximum grain size is as much as $1.28 \mathrm{~mm}$ in one sample from the Square Lake test wel1 (appendix 1). The maximum grain size of most samples is 0.20 to $0.40 \mathrm{~mm}$, or upper fine to medium sand (Folk, 1968), but maximum grain sizes are slightly coarser in the eastern samples in both the surface and subsurface, approaching 0.40 to $0.65 \mathrm{~mm}$ (upper medium to lower coarse sand). Modal grain sizes are 0.25 $\mathrm{mm}$ or less in most outcrop and subsurface samples; most samples are fine-grained to very fine grained sandstone and siltstone, although some are medium- and coarse-grained sandstone. Moderate sorting characterizes the samples, but samples in the east are slightly better sorted. The majority of grains making up the sandstones have long contacts; and a significant number have concavo-convex contacts, indicating that some presolution, formation of quartz overgrowths, or siliceous cementation has taken place. Visible porosity is characteristically low in the sandstones examined, although isolated samples have as much as 18.8 percent visible porosity. Estimates of packing densities of the samples are commonly high, but surface samples in the eastern suite have nearly equal percentages of samples with low packing densities. Percentages of matrix and cement are greatest in the western surface samples (all are greater than 20 percent), and significant amounts are present in many of the rest of the samples.

Ternary diagrams (fig. 33) of surface and subsurface samples with framework-matrix-cement end-members indicate that the sandstones have moderate to poor reservoir qualities. Recalculated percentages of matrix range from 3.6 to 37.0 (mean, 14.6 percent) in the surface samples and from 3.6 to 42.0 (mean, 18.3 percent) in the subsurface samples (appendix 2). Percentages of cement in the surface samples range from 0.9 to 57.4 (mean, 16.1 percent); in the subsurface, percentages of cement range from 


\begin{tabular}{|c|c|c|c|c|c|c|}
\hline $\begin{array}{l}\text { MAX } \\
\text { GRAIN } \\
\text { SIZE } \\
(M m)\end{array}$ & $\begin{array}{l}\text { MODAL } \\
\text { GRAIN } \\
\text { SIZE } \\
(\mathrm{Mm})\end{array}$ & SORTING & $\begin{array}{l}\text { GRAIN } \\
\text { CONTACTS }\end{array}$ & $\begin{array}{l}\text { TEXTURAL } \\
\text { COMPONENTS }\end{array}$ & $\begin{array}{c}\text { MATRIX } \\
+ \\
\text { CEMENT } \\
\text { (percent) }\end{array}$ & $\begin{array}{l}\text { PACKING } \\
\text { DENSITY }\end{array}$ \\
\hline
\end{tabular}

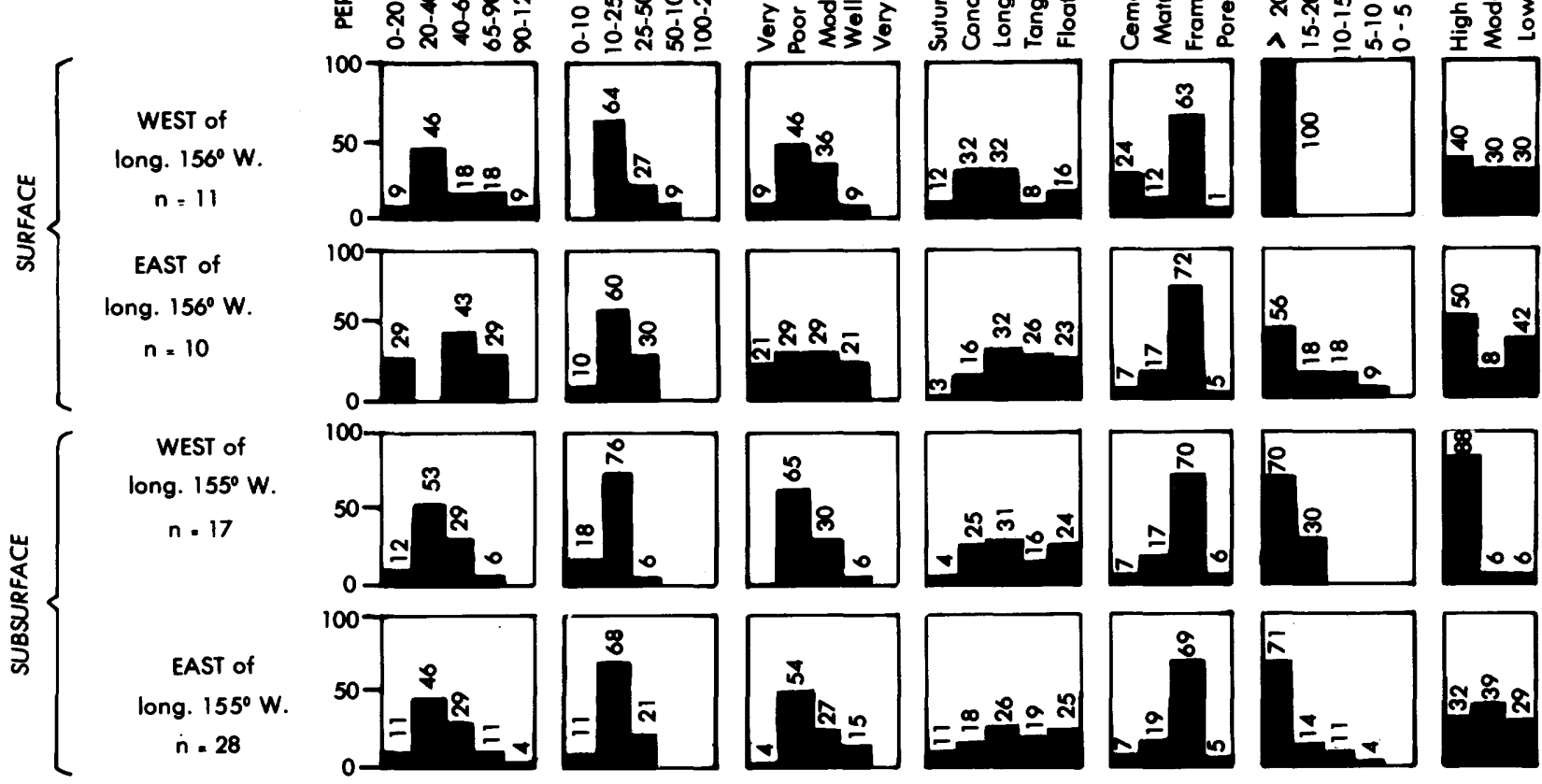

Figure 32.--Textural properties of the surface and subsurface sandstones from the Nanushuk Group. The most favorable reservoir characteristics for each textural category appear toward the right of each parameter shown. $n$, number of samples.

0.6 to 21.2 (mean, 7.2 percent). The percentage of matrix in surface and subsurface rocks is nearly the same; however, the amount of calcite cement present in surface samples in the west is greater than that in any of the rest of the samples. Perhaps weathering of calcite grains plays a role in the formation of the calcite cement in the western suite. In the subsurface, it is possible that only the Kaolak test well penetrated the western province of the Nanushuk. Group; in this well, calcareous cement was only as high as 5.7 percent, with pseudomatrix, constituting as much as 22.3 percent, being the dominant intergranular constituent. In the subsurface, comparisons of samples from western and eastern provinces show more subtle differences than comparisons of surface samples from the two provinces. The eastern rocks in the subsurface apparently contain slightly more matrix material than is present in the surface rocks.

\section{MINERALOGY}

Sandstones of the Nanushuk Group typically contain about 50 percent quartzose grains, and they are compositionally litharenites (Folk,
1968). In determining grain compositions, the conventions described by Dickinson (1970) were followed, except that the polycrystalline quartz category includes all polycrystalline quartz grains, even though individual crystallite dimensions may have been less than 0.03 $\mathrm{mm}$. Chert grains include only fibrous or chalcedonic varieties. Data from the modal analyses are presented in appendix 2 . Surface and subsurface rocks have similar plots on the Q-F-L triangle, but the subsurface rocks apparently contain slightly more quartz and feldspar. An average surface sample contains 50.5 percent monocrystalline and polycrystalline quartz, quartzite, and chert grains (Q), 4.6 percent feldspar grains $(F)$, and 44.9 percent 1ithic grains (L). In the subsurface, an average sample contains 52.6 percent $Q, 5.8$ percent $F$, and 41.7 percent $L$. According to Folk (1968), these rocks are litharenites, and their compositions agree with those of Nanushuk samples from Umiat test well 11 studied by Fox and others (1979). A ternary plot of monocrystalline quartz $(\mathrm{Qm})$; feldspar $(\mathrm{F})$; and total lithic fragments, polycrystalline quartz, and chert (Lt) shows patterns similar to those of the Q-F-L plots just described. On 

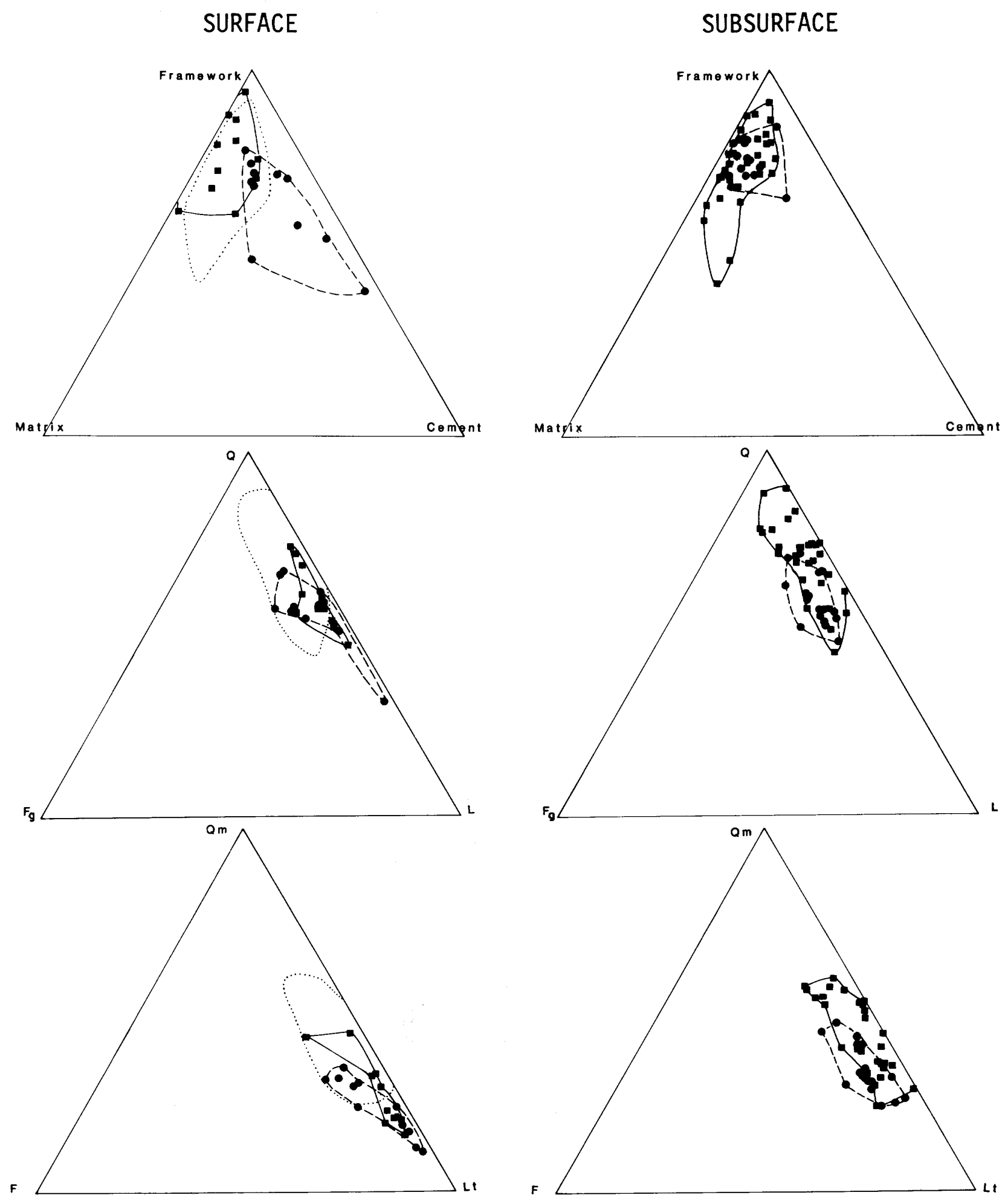

Figure 33.--Ternary plots of surface and subsurface sandstones, Lower and Upper Cretaceous Nanushuk Group, Alaska. Squares, with fields enclosed by solid lines, indicate samples from the eastern portion of the area (east of long $156^{\circ} \mathrm{W}$. in the surface samples and 1 ong $155^{\circ} \mathrm{W}$. in the subsurface samples); circles, with fields enclosed by dashed lines, indicate samples from the western part of the area. For convenience, the dotted line on the surface diagrams enclose the field of the subsurface plots, which are shown in detail on the right-hand 


\section{SURFACE}

\section{SUBSURFACE}
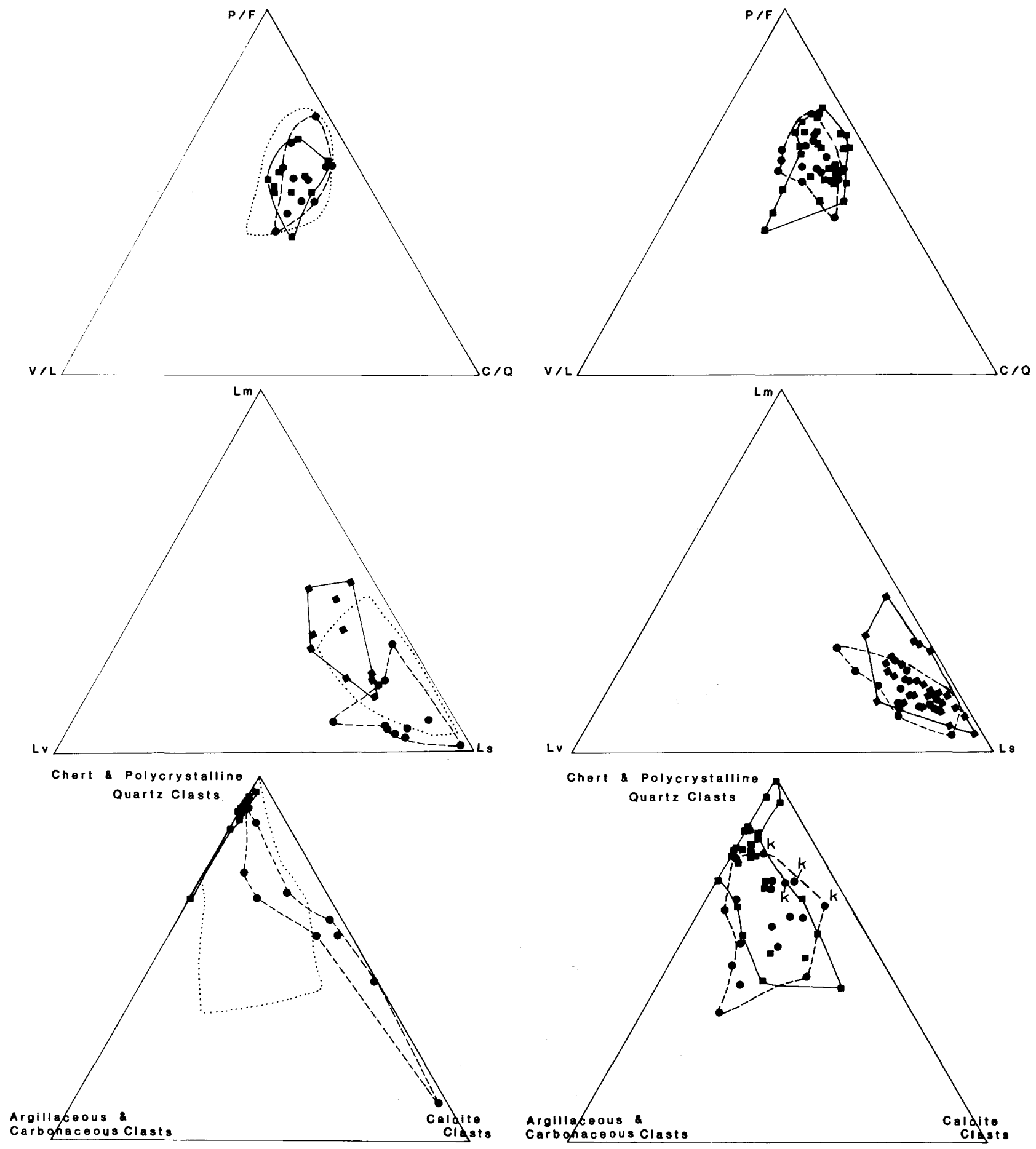

diagrams. Q, monocrystalline and polycrystalline quartz, quartzite, and chert; F, feldspar; L, lithic grains; Qm, monocrystalline quartz; Lt, total lithic fragments, polycrystalline quartz, and chert; $\mathrm{P} / \mathrm{F}$, ratio of plagioclase to total feldspars; V/L, ratio of volcanic lithic grains to total lithic grains; $\mathrm{C} / \mathrm{Q}$, ratio of polycrystalline quartz and quartzose grains to total quartzose grains; Lm, metamorphic lithic grains, Lv, volcanic lithic grains; and Ls, sedimentary lithic grains. " $k$ " indicates samples from the westernmost well, the Kaolak test well. 
the surface, an average sample contains 24.6 percent Qm, 7.1 percent $F$, and 68.3 percent Lt. In the subsurface, an average sample is composed of 39.2 percent $Q m, 7.4$ percent $F$, and 53.4 percent Lt. The subsurface samples are composed of about 15 percent more monocrystalline quartz than the surface samples. Ternary plots of the ratios of plagioclase to total feldspars ( $P / F)$, of polycrystalline quartz and quartzite grains to total quartzose grains $(\mathrm{C} / \mathrm{Q})$, and of volcanic 1ithic grains to total lithic grains (V/L) are nearly identical in the surface and subsurface, plotting near the midpoint between the $\mathrm{C} / \mathrm{Q}$ and P/F poles.

A ternary plot of 1ithic grain types with volcanic-sedimentary-metamorphic end-members and one of sedimentary 1ithic clast types with total chert and polycrystalline quartz clastscalcite clasts-argillaceous and carbonaceous clasts as end-members reveal striking differ- ences in 1ithic grain compositions between the eastern and western suites of rocks, which show up particularly well in the surface samples. The subsurface samples do not plot as distinctively as the surface samples, though the average compositions have subtle variations corresponding to those of the surface samples. It is noteworthy that samples from the Kaolak test well fall within boundaries of the western suite on the surface plots. It is also of interest that the subsurface plots seem to fall between the two provinces of surface samples, as though indicating a gradational transition or interfingering of lithic types. Average lithic and sedimentary clast compositions of surface and subsurface samples are shown in table 4. These figures show that, in the surface and the subsurface, (1) a higher percentage of sedimentary lithic clasts is found in the western samples and a higher percentage

Table 4.--Average compositions of Iithic clast and sedimentary lithic clast in samples from the Nanushuk Group, western North Slope, Alaska

[Lv, volcanic lithic grains; Ls, sedimentary lithic grains; Lm, metamorphic lithic grains; Q, monocrystalline and polycrystalline quartz, quartzite, and chert]

\begin{tabular}{cc}
\hline $\begin{array}{c}\text { Lithic-clast compositions } \\
\text { (in percent) }\end{array}$ & Sedimentary $\begin{array}{l}\text { lithic-clast compositions } \\
\text { (in percent) }\end{array}$ \\
\hline
\end{tabular}

Surface samples

Overa11: $\quad \mathrm{Lv}=15.1$

$\mathrm{Ls}=65.4$

$\mathrm{Lm}=19.5$

Eastern province:

$\mathrm{Lv}=15.7$

$\mathrm{L} s=54.0$

$\mathrm{Lm}=30.2$

Western province:

$\mathrm{Lv}=14.3$

$\mathrm{Ls}=76.7$

$\mathrm{Lm}=9.0$
Chert and polycrystalline $Q=73.1$

Calcite clasts $=18.4$

Argillaceous-carbonaceous clasts $=8.5$

Chert and polycrystalline $Q=73.1$

Calcite clasts $=18.4$

Argillaceous-carbonaceous clasts $=8.5$

Chert and polycrystalline $Q=61.3$

Calcite clasts $=31.1$

Argillaceous-carbonaceous clasts $=7.6$

Subsurface samples

Overa11: $\quad \mathrm{Lv}=10.1$

Ls $=71.6$

$\mathrm{Lm}=18.3$

Eastern province:

$\mathrm{Lv}=8.5$

$\mathrm{Ls}=71.5$

$\mathrm{Lm}=20.0$

Western province:

$\mathrm{Lv}=12.1$

Ls $=72.3$

$\mathrm{Lm}=15.6$
Chert and polycrystalline $Q=67.7$

Calcite clasts $=13.6$

Argillaceous-carbonaceous clasts $=78.7$

Chert and polycrystalline $Q=87.3$

Calcite clasts $=2.7$

Argillaceous-carbonaceous clasts $=10.0$

Chert and polycrystalline $Q=61.3$

Calcite clasts $=31.1$

Argillaceous-carbonaceous clasts $=7.6$ 
of metamorphic lithic clasts is found in the eastern samples, (2) a nearly uniform percentage of volcanic rock fragments is found throughout the area, (3) a higher percentage of quartzose grains is found in the eastern samples, and (4) a striking increase in percentage of calcite clasts is found in the western suite. The calcite clasts are recognized by being rounded and by their coating of lutum, or reddish-brown (hematite?) stain. The grains are characteristically recrystallized and show no internal depositional structures or textures. When observed under cathodoluminescent light, however, the grains luminesce red and orange, while the surrounding calcite cement luminesces bright yellow, indicating two separate origins for the calcite in the grains and in the cement (E. S. Sprunt, ora1 commun., 1978).

\section{ALTERATION OF THE SANDSTONES}

Nearly all of the sandstones contain at least small amounts of pseudomatrix (alteration of softer 1ithic grains by squeezing). Quartz grains are commonly strained and cracked, and many feldspar twins are offset or bent. The sandstones often have a screen of chlorite and sericite that alters the framework grains, particularly the feldspars, micas, and lithic grains. Most micas show the effects of compaction and squeezing, and many have been altered to chlorite or "exploded" by calcite or silica cement.

Interstitial secondary cements are typically present. Abundant, though scattered, occurrences of siliceous overgrowths and minor occurrences of feldspar overgrowths are also found. No zeolite cement was observed. The amount of siliceous overgrowth, presolution, and cementation that has taken place is unknown and may not be determined readily. When examined under cathodoluminescent light, most quartz grains in the Nanushuk samples luminesce du11 red, while a small number of grains luminesce blue. Therefore, siliceous overgrowths on grains in the Nanushuk rocks have been recognized under the microscope as interpenetration of grains or mosaic patches or, where present, by a readily visible clay $\mathrm{rim}$ around the original grain. Silica cement has been observed as pore filling as well. In Sample No. 3375, two possible stages of silica cementation can be recognized (fig. 34A). In places, calcite cement can be seen developing on the silica cement. Kaolinite commonly fills pores and was probably deposited after a primary, iron-rich(?) clay pore-lining stage (fig. 35A). An example from the Kaolak test well (937-ft or 286-m depth) shows a moderate amount of clay pore-lining (fig. 35B). Sample No. 2075 shows evidence of another sequence of events. Leached potassium feldspars, which create a secondary porosity (fig. 34B), are then filled with kaolinite (fig. 34C). The kaolinite is then replaced in some areas by calcite cement.
The most abundant clay minerals, as determined by X-ray analyses, are illite-mica, chlorite, and kaolinite (appendix 3). X-ray analyses of all samples from the Nanushuk Group show that montmorillonite was found in only trace amounts.

\section{POROSITY}

Most pores are lined with a reddish-brown, probably iron-rich, coating. All gradations of the lining are present, from no pore lining to complete closing of the pores. Figure $35 \mathrm{C}$ shows pore size being decreased by development of siliceous grain overgrowth. In the eastern province, there are examples of secondary porosity being developed by leaching of feldspars. Some of the pores have been successively filled by kaolinite; others are left vacant. Localized occurrences of secondary porosity, which developed as a result of cracking of quartzose grains, were also observed. These two factors may increase porosity in localized areas.

Appendix 4 lists the porosity and permeability data of the subsurface samples examined for this study. The data were summarized from Robinson (1956, 1958, 1959a, b, c, 1964) and Collins (1958b, c, 1959). Porosity and permeability tests were not conducted on the surface samples.

\section{PROVENANCE}

Monocrystalline and polycrystalline quartz, quartzite, and chert grains (Q) typically make up about 50 percent of the sandstones from the Nanushuk Group, with the feldspar (F) averaging about 5 percent and the 1ithic grains (L) averaging 45 percent. These percentages, the abundance of detrital carbonate rock in the west, and the abundance of finely polycrystalline quartz grains are characteristic of a "tectonic" provenance (Dickinson, 1970). Minor input from volcanic or plutonic terranes of intermediate composition is suggested by the high $\mathrm{P} / \mathrm{F}$ ratios, the low to moderate $\mathrm{V} / \mathrm{L}$ ratios, and the paucity of potassium feldspar grains in most samples. Because many of the quartz grains have overgrowths, some of the detritus may be recycled.

Beginning in Jurassic time, uplift and northward-directed thrust faulting occurred in the Brooks Range and in the Herald Arch (Grantz and others, 1976; Grantz and Kirschner, 1976), forming a structural high composed, in part, of Silurian to Triassic clastic, carbonate, and chert sequences. The rising thrust belt shed debris into the Colville geosyncline, which formed on its north side (Grantz and Kirschner, 1976). The most likely sources for the Nanushuk rocks deposited into the Colville geosyncline are the clastic sediments that are found in the present-day nappe sequences of the Brooks Range (Grybeck and others, 1977). The mineralogical characteristics and the general distribution of 

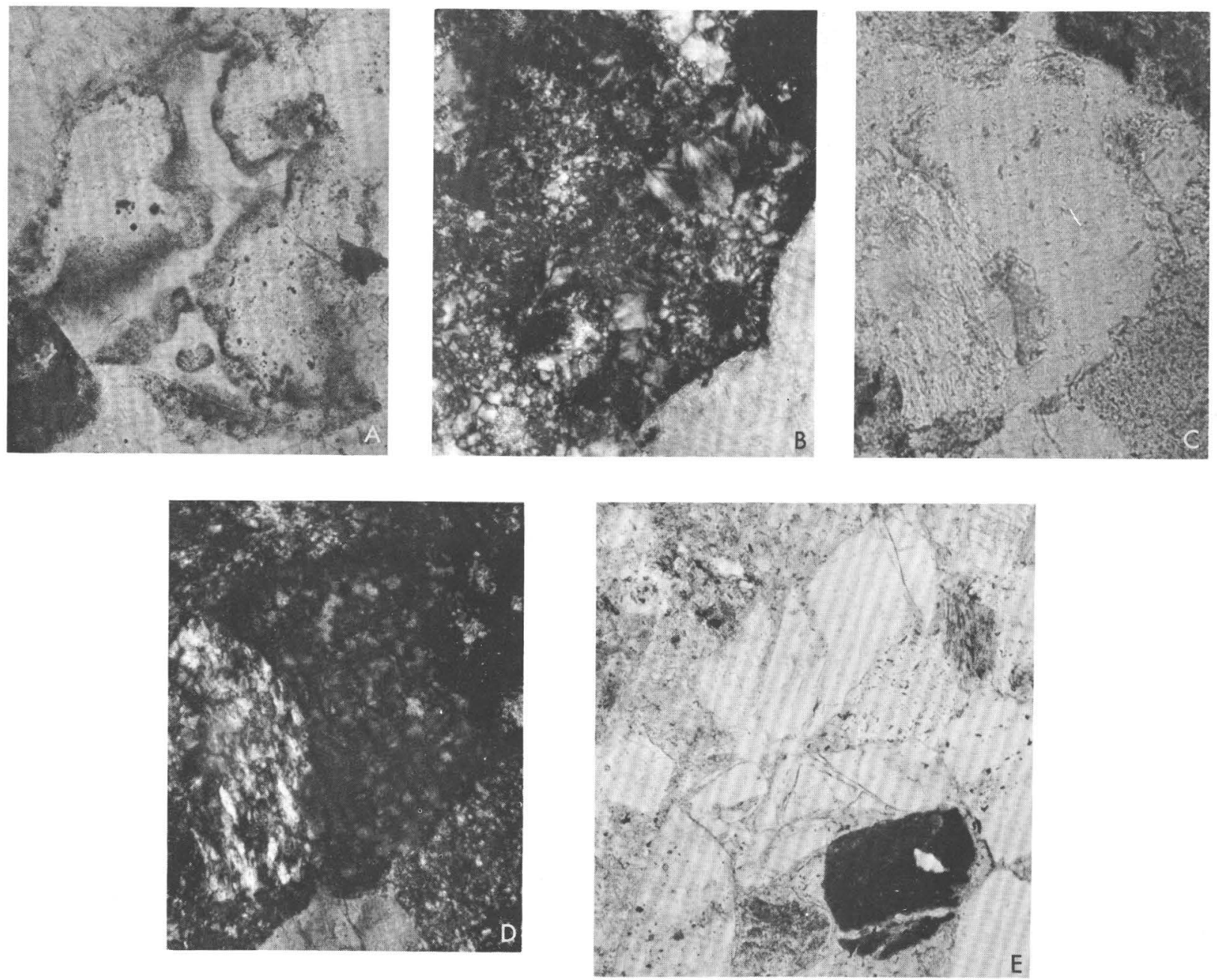

Figure 34.--Photomicrographs of pore-1inings in sandstones of the Nanushuk Group. A, Two possible stages of silica cementation can be seen in this sample from the western province (Sample No. 3375, approx. 65X, plain 1ight). B, Same, polarized light. C, Potassium feldspar is often leached, creating secondary porosity in some rocks (Sample No. 2075, approx. 65X, plain light). $D$, The pores then sometimes become sites for accumulation of kaolinite clay (same as $C$, polarized light). E, In some samples, cracked grains create secondary porosity (Sample No. 2275, approx. 65X, plain light).

carbonate clasts in the west and quartzose and metamorphic clasts in the east suggest two different dominant source terranes for the sandstones. Extensive carbonate outcrops of Mississippian to Pennsylvanian and locally Permian Lisburne Group, along with the SilurianDevonian and possibly Ordovician limestones making up the Baird Group rocks (Brosgé and Tailleur, 1971), may be primary sources for the calcareous clasts of the western province of sandstones of the Nanushuk Group. The Herald Arch, in part, may be the structural high from which much of the detritus from the western province was shed (Grantz and others, 1976). The Endicott Group consists of the Upper Devonian Hunt Fork Shale and Kanayut Conglomerate and of the Lower Mississippian Kayak Shale
(Brosgé and Tailleur, 1971) in the Endicott Mountains and has extensive outcrops in the central and eastern Brooks Range. This group, as well as the metamorphosed rocks farther to the south in the Brooks Range (Grybeck and others, 1977), may be the source of the metamorphic lithic and quartzose grains which predominate in the eastern province of the sandstones of the Nanushuk Group.

\section{PETROLEUM POSSIBILITIES}

A scattering of subsurface and surface samples was studied; a preliminary prognosis is that the sandstones have generally marginal reservoir characteristics. The amount of matrix averages about 18 percent, and all 

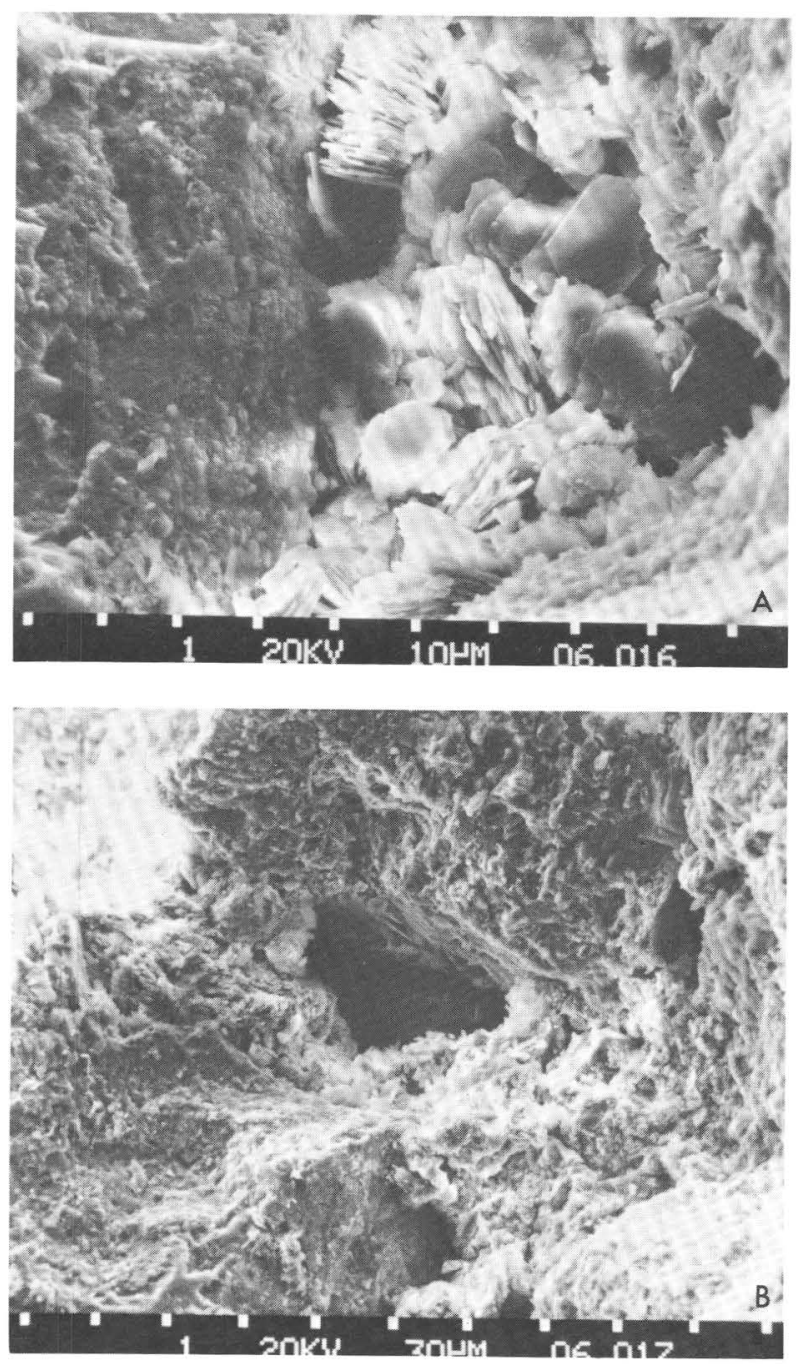

samples show evidence of compaction or squeezing which has created considerable pseudomatrix. Many samples apparently contain quartz grains with overgrowths. Cements include primary iron-rich(?) clay and secondary illite, kaolinite, calcite, silica, and minor chlorite. These diagenetic features all adversely affect porosity and permeability of the Nanushuk

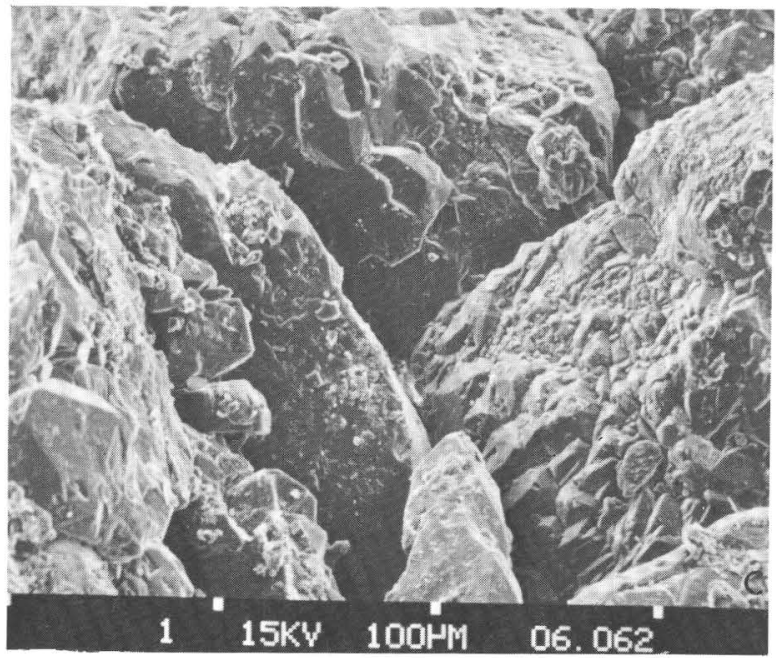

Figure 35.--Scanning electron microscope photographs of pore-linings in sandstones of the Nanushuk Group. A, Kaolinite is a common, if unwelcome, pore-filling cement and was probably deposited after a primary, iron-rich(?) pore-lining stage. This sample is from the $937-\mathrm{ft}$ or $286-\mathrm{m}$ depth, Kaolak test well. $B$, Often, only moderate amounts of clay line the pores (Kaolak test we11, 937-ft or 286-m depth). C, Pores may be considerably narrowed by development of siliceous grain overgrowths or by presolution of tightly packed grains (Sample No. 1475). rocks. On the other hand, in one surface sample, the visible porosity is 18.8 percent, and in the subsurface, average visible porosity is slightly improved over that of surface samples. This improvement in porosity may be related, in part, to leaching of feldspar grains and to the cracking of quartz grains observed in a few samples. 
Appendix 1.--Textural data from 21 surface and 45 subsurface samples of sandstone from the Lower and Upper Cretaceous Nanushuk Group, western North Slope, Alaska

\begin{tabular}{|c|c|c|c|c|c|c|c|}
\hline $\begin{array}{l}\text { Sample } \\
\text { No. }\end{array}$ & $\begin{array}{c}\text { Maximum } \\
\text { grain size }\end{array}$ & $\begin{array}{l}\text { Modal } \\
\text { grain size }\end{array}$ & Sorting & $\begin{array}{l}\text { Type of grain } \\
\text { contacts }\end{array}$ & Cements $^{2}$ & $\begin{array}{l}\text { Percent } \\
\text { matrix }\end{array}$ & $\begin{array}{l}\text { Packing } \\
\text { density }\end{array}$ \\
\hline \multicolumn{8}{|c|}{ Surface } \\
\hline 1075-_-_-_-_- & 0.15 & 0.07 & Very poor & $\mathrm{L}, \mathrm{P}, \mathrm{F}$ & $\mathrm{A}$ & 38.7 & Low. \\
\hline 1175 & .45 & .20 & Very poor & $\mathrm{L}, \mathrm{P}, \mathrm{F}$ & $\mathrm{A}$ & 32.6 & High. \\
\hline 1275- & .45 & .20 & Poor----- & $C, I$ & A & 28.2 & High. \\
\hline 1475- & .70 & .30 & Moderate- & $\mathrm{L}, \mathrm{P}$ & $\mathrm{B}$ & 4.6 & Moderate. \\
\hline 1575- & .70 & .40 & Poor-- - & $\mathrm{L}, \mathrm{P}$ & $A, B$ & 24.6 & High. \\
\hline 1875--- & .17 & .11 & We11----- & $C, L$ & A & 19.8 & High. \\
\hline 2075--ー----- & .77 & .38 & Moderate- & $S, C, L$ & $\mathrm{~A}$ & 19.2 & High. \\
\hline 2175-ー-ー-ー-- & .56 & .18 & We11---- & $\mathrm{C}, \mathrm{L}$ & A & 11.7 & High. \\
\hline 2675 & .45 & .12 & Poor----- & $\mathrm{C}, \mathrm{L}, \mathrm{P}, \mathrm{F}$ & $A, B$ & 29.1 & High. \\
\hline 3075--------- & .18 & .12 & Very poor & $\mathrm{F}$ & $\mathrm{B}$ & 40.3 & Low. \\
\hline 3275- & .35 & .18 & Poor----- & $\mathrm{S}, \mathrm{C}, \mathrm{L}$ & $A, B$ & 30.3 & High. \\
\hline 3375- & .76 & .46 & Moderate- & $\mathrm{S}, \mathrm{C}, \mathrm{L}$ & A & 29.1 & High. \\
\hline 3675--- & .36 & .18 & Poor----- & $\mathrm{C}, \mathrm{L}$ & $A, B$ & 31.8 & Moderate. \\
\hline 3875--_- & .38 & .18 & Poor----- & $S, C, L$ & $A, B$ & 29.6 & High. \\
\hline 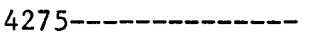 & .39 & .23 & Moderate- & $P, F$ & B & 51.7 & Low. \\
\hline 4375--- & .92 & .38 & Poor----- & $C, L$ & $\mathrm{~A}$ & 25.3 & High. \\
\hline 4575- & .18 & .15 & Poor-- - & $\mathrm{F}$ & $\mathrm{B}$ & 61.0 & Low. \\
\hline 4875---------- & .46 & .24 & Moderate- & $\mathrm{C}, \mathrm{L}$ & $\mathrm{A}$ & 28.0 & Moderate. \\
\hline $5175-$ & .45 & .30 & We11- - - & $\mathrm{F}$ & $\mathrm{B}$ & 46.0 & Low. \\
\hline 5375 & .38 & .16 & Very poor & $\mathrm{C}, \mathrm{L}, \mathrm{F}$ & $\mathrm{B}$ & 42.4 & Low. \\
\hline 5475- & .90 & .58 & Moderate- & $\mathrm{C}, \mathrm{L}, \mathrm{P}$ & $\mathrm{A}$ & 20.5 & Moderate. \\
\hline \multicolumn{8}{|c|}{ Subsurface } \\
\hline Meade 2953------ & 0.38 & 0.23 & WeIl-_-_- & $\mathrm{C}, \mathrm{L}$ & $\mathrm{A}$ & 15.6 & High. \\
\hline Meade 4133------ & .45 & .23 & Poor----- & $\mathrm{S}, \mathrm{C}, \mathrm{L}$ & $\mathrm{A}$ & 27.2 & High. \\
\hline Wolf Creek 1-867-- & .58 & .30 & Very poor & $S, C, F$ & B & 24.4 & Low. \\
\hline Wolf Creek 3-1553- & .58 & .30 & We11---- & $\mathrm{C}, \mathrm{L}$ & $\mathrm{A}$ & 7.4 & Moderate. \\
\hline Wolf Creek 3-2050- & .45 & .17 & Poor----- & $\mathrm{S}, \mathrm{C}, \mathrm{F}$ & $A, B$ & 27.1 & High. \\
\hline Wolf Creek 3-2532- & .46 & .20 & Poor---- & $\mathrm{S}, \mathrm{C}, \mathrm{F}$ & $A, B$ & 25.6 & High. \\
\hline Wolf Creek 3-3109- & .12 & .09 & Poor----- & $\mathrm{F}$ & $\mathrm{B}$ & 52.2 & Low. \\
\hline Wolf Creek 3-3509- & .23 & .13 & Poor----- & $\mathrm{F}$ & B & 58.4 & Low. \\
\hline
\end{tabular}


Oumalik 979-84--Oumalik 1606-- -

Oumalik 3260

Oumalik $3752.5-$

Knifeblade 2A-172-

Knifeblade 2A-792-

Knifeblade 2A-1557

Kaolak 937-_-_-_-

Kaolak 2453-_..--

Kaolak 3187-_-_-_-

.58

.60

.30

Kaolak 4078

.30

Simpson 454-----.-

Simpson 829-_---

.18

Simpson 979-_.--

Grandstand 364-69-

Grandstand 862-82-

Grandstand 2484---

$$
.90
$$

Topagoruk 304-----

Topagoruk 603--.-

Topagoruk 1204---

Topagoruk 1790----

.38

.38

.77
.23

Titaluk 539-------

Titaluk 2675-_-_-

Titaluk 3004-_-

Titaluk 3306

Titaluk 3431-_-_-_-$$
.23
$$

.34

.36

.23

Gubik 3112--_-_--

Gubik 3529--_-_-_-

Gubik 3645-------

Gubik 3822--

Gubik 4243

Square Lake 1685-Square Lake 1854-Square Lake 1916-Square Lake 3036-Square Lake 3480Square Lake 3856--
Poor----

Poor----

Poor--

Poor-- -

Moderate-

Well-_-_-

Moderate-

Moderate-

Poor---

Poor----

Poor----

Poor----

Poor----

We11- - -

Very poor

Very poor

Poor---

Moderate-

Moderate-

Moderate-

Moderate-

Moderate-

Poor----

Poor----

Moderate-

Moderate-

Poor--

Poor----

Poor---_-

Poor-- -

Moderate-

Poor----

Moderate-

Poor---
C, F

$C, \mathrm{~L}$

$C, L, P, F$

$A, B$

$A, B$

A, B

24.2

26.3

28.3

25.1

19.7

C, L

C, L

A

A, B

28.2

22.3

C, L, F

C, L, F
C, L, F

S, C, L, F

A

$\mathrm{A}, \mathrm{B}$

A, B

24.8

32.0

28.9

28.4

$C, L, P, F$

$C, L, P, F$

A, B

L, P, F

A, B

20.2

18.1

17.6

$S, C, L$

$S, C, L$

11.0

A, B

A

16.0

35.0

L, P, F

L, $P$

L, $P$

C, L, P, F

34.8

18.9

18.7

28.7

C, L, P

S, C, L

$\mathrm{L}, \mathrm{P}$

C, L, F
P, F

23.0

17.6

26.3

20.0

25.0

L, P, F

$L, P, F$

$\mathrm{P}, \mathrm{F}$

$S, C, L$

L, P, F

L, P, F

L, P, F
L, P, F

$S, C, L, P$

L, P, F

F,
High.

High.

High.

High.

Moderate.

Low.

Moderate.

High.

High.

High.

High.

High.

High.

Moderate.

High.

High.

Low.

Low.

High.

High.

High.

Moderate.

High.

High.

High.

Moderate.

Moderate.

High.

Low.

High.

Low.

Moderate.

Moderate.

Moderate.

Moderate.

Moderate.

Low.

\footnotetext{
${ }^{1} \mathrm{~S}$, sutured; C, concavo-convex; L, long, straight; $P$, point, tangent; F, floating.
}

$2 \mathrm{~A}$, grain contacts; B, authigenic cement. 
Appendix 2.--Modal analyses of 21 surface and 45 subsurface samples of sandstone from the Lower and Upper Cretaceous Nanushuk Group, western North Slope, Alaska

[Q, monocrystalline and polycrystalline quartz, quartzite, and chert; Qm, monocrystalline quartz; P, plagioclase; K, potassium feldspar; Lv, volcanic lithic grains; Lm, metamorphic lithic grains; Ls, sedimentary lithic grains; Cc, calcite clasts; $\mathrm{Cq}$, chert and polycrystalline quartz; Ac, argillaceous and carbonaceous. All values are in percent; and percentages of pores, matrix, cement, and framework grains have been recalculated to total 1.00 percent]

\begin{tabular}{|c|c|c|c|c|c|c|c|c|c|c|c|c|c|c|}
\hline $\begin{array}{l}\text { Sample } \\
\text { No. }\end{array}$ & $Q$ & Qm & $\mathbf{P}$ & $\mathrm{K}$ & $\mathrm{Lv}$ & $\mathrm{Lm}$ & Ls & $\mathrm{Cc}$ & $\mathrm{Cq}$ & $\mathrm{Ac}$ & Pores & Matrix & Cement & $\begin{array}{c}\text { Framework } \\
\text { grains }\end{array}$ \\
\hline \multicolumn{15}{|c|}{ Surface } \\
\hline $\begin{array}{l}1075-1- \\
1175- \\
1275 \\
1475- \\
1575-\end{array}$ & $\begin{array}{l}32.3 \\
29.7 \\
38.1 \\
52.7 \\
42.0\end{array}$ & $\begin{array}{l}19.7 \\
12.3 \\
11.0 \\
24.8 \\
16.7\end{array}$ & $\begin{array}{l}2.7 \\
2.0 \\
2.7 \\
2.0 \\
3.7\end{array}$ & $\begin{array}{l}0.0 \\
0.0 \\
0.0 \\
0.0 \\
0.0\end{array}$ & $\begin{array}{l}4.4 \\
8.0 \\
7.6 \\
9.9 \\
3.1\end{array}$ & $\begin{array}{r}16.4 \\
21.8 \\
17.6 \\
9.8 \\
24.7\end{array}$ & $\begin{array}{l}19.0 \\
18.8 \\
28.3 \\
29.5 \\
25.6\end{array}$ & $\begin{array}{r}0.1 \\
0.0 \\
0.0 \\
0.0 \\
.3\end{array}$ & $\begin{array}{l}12.6 \\
17.1 \\
26.3 \\
26.7 \\
24.5\end{array}$ & $\begin{array}{r}6.3 \\
1.7 \\
2.0 \\
2.8 \\
.8\end{array}$ & $\begin{array}{r}0.0 \\
0.0 \\
2.0 \\
18.8 \\
0.0\end{array}$ & $\begin{array}{r}37.0 \\
25.9 \\
21.6 \\
3.7 \\
10.8\end{array}$ & $\begin{array}{r}1.7 \\
6.7 \\
6.6 \\
.9 \\
13.8\end{array}$ & $\begin{array}{l}61.3 \\
67.4 \\
69.8 \\
76.6 \\
75.4\end{array}$ \\
\hline $\begin{array}{l}\text { 1875 } \\
2075- \\
2175 \\
2675 \\
3075-\end{array}$ & $\begin{array}{l}57.2 \\
56.5 \\
42.8 \\
47.6 \\
31.7\end{array}$ & $\begin{array}{l}34.3 \\
15.7 \\
21.3 \\
29.3 \\
12.3\end{array}$ & $\begin{array}{l}2.3 \\
2.0 \\
2.0 \\
8.3 \\
2.0\end{array}$ & $\begin{array}{r}.3 \\
.7 \\
0.0 \\
1.3 \\
0.0\end{array}$ & $\begin{array}{r}5.5 \\
9.7 \\
12.2 \\
4.0 \\
9.9\end{array}$ & $\begin{array}{r}8.5 \\
9.0 \\
13.9 \\
5.6 \\
14.4\end{array}$ & $\begin{array}{l}26.8 \\
41.6 \\
23.4 \\
19.1 \\
20.7\end{array}$ & $\begin{array}{r}0.0 \\
0.0 \\
.3 \\
0.0 \\
0.0\end{array}$ & $\begin{array}{l}22.9 \\
38.3 \\
20.6 \\
18.0 \\
19.4\end{array}$ & $\begin{array}{l}3.9 \\
3.3 \\
2.5 \\
1.1 \\
1.3\end{array}$ & $\begin{array}{r}1.0 \\
1.0 \\
13.0 \\
1.7 \\
0.0\end{array}$ & $\begin{array}{r}18.1 \\
13.3 \\
9.1 \\
13.8 \\
23.7\end{array}$ & $\begin{array}{r}1.7 \\
5.9 \\
2.6 \\
15.3 \\
16.6\end{array}$ & $\begin{array}{l}79.2 \\
79.8 \\
75.3 \\
69.2 \\
59.7\end{array}$ \\
\hline $\begin{array}{l}3275- \\
3375 \\
3675 \\
3875 \\
4275\end{array}$ & $\begin{array}{l}37.5 \\
40.2 \\
36.9 \\
40.9 \\
15.2\end{array}$ & $\begin{array}{r}21.0 \\
8.3 \\
23.6 \\
11.3 \\
11.3\end{array}$ & $\begin{array}{r}7.7 \\
2.3 \\
6.0 \\
2.7 \\
.7\end{array}$ & $\begin{array}{r}.3 \\
0.0 \\
.3 \\
0.0 \\
.3\end{array}$ & $\begin{array}{l}6.5 \\
8.4 \\
4.7 \\
9.7 \\
1.0\end{array}$ & $\begin{array}{r}2.7 \\
2.1 \\
2.4 \\
3.3 \\
.3\end{array}$ & $\begin{array}{l}28.2 \\
47.7 \\
30.6 \\
43.0 \\
34.3\end{array}$ & $\begin{array}{r}10.0 \\
7.7 \\
17.3 \\
9.7 \\
30.0\end{array}$ & $\begin{array}{r}16.0 \\
31.9 \\
12.4 \\
29.3 \\
3.6\end{array}$ & $\begin{array}{r}2.2 \\
8.1 \\
.9 \\
4.0 \\
.7\end{array}$ & $\begin{array}{r}1.7 \\
.3 \\
0.0 \\
0.0 \\
.3\end{array}$ & $\begin{array}{r}15.0 \\
8.3 \\
15.3 \\
6.4 \\
26.0\end{array}$ & $\begin{array}{l}15.3 \\
20.8 \\
16.5 \\
23.2 \\
25.7\end{array}$ & $\begin{array}{l}68.0 \\
70.6 \\
68.2 \\
70.4 \\
48.0\end{array}$ \\
\hline $\begin{array}{l}4375-1- \\
4575 \\
\text { 4875- } \\
5175 \\
5375\end{array}$ & $\begin{array}{l}49.6 \\
25.8 \\
36.0 \\
30.4 \\
32.3 \\
43.9\end{array}$ & $\begin{array}{r}22.3 \\
11.4 \\
13.3 \\
12.7 \\
17.7 \\
8.0\end{array}$ & $\begin{array}{l}6.0 \\
3.3 \\
2.3 \\
5.7 \\
5.3 \\
1.7\end{array}$ & $\begin{array}{r}0.0 \\
0.0 \\
0.0 \\
.3 \\
3.3 \\
0.0\end{array}$ & $\begin{array}{r}6.3 \\
1.0 \\
3.6 \\
3.9 \\
5.0 \\
18.5\end{array}$ & $\begin{array}{l}8.0 \\
7.0 \\
4.6 \\
6.9 \\
1.4 \\
4.6\end{array}$ & $\begin{array}{l}31.3 \\
15.7 \\
47.0 \\
24.0 \\
24.0 \\
39.0\end{array}$ & $\begin{array}{r}1.7 \\
.3 \\
26.0 \\
2.3 \\
8.7 \\
0.0\end{array}$ & $\begin{array}{l}27.3 \\
14.4 \\
20.7 \\
17.7 \\
14.6 \\
35.6\end{array}$ & $\begin{array}{r}2.3 \\
1.0 \\
.3 \\
4.0 \\
.7 \\
3.4\end{array}$ & $\begin{array}{l}.7 \\
0.0 \\
0.0 \\
0.0 \\
0.0 \\
5.4\end{array}$ & $\begin{array}{r}13.0 \\
3.6 \\
13.6 \\
5.3 \\
10.4 \\
11.7\end{array}$ & $\begin{array}{r}12.3 \\
57.4 \\
14.4 \\
40.7 \\
32.0 \\
8.8\end{array}$ & $\begin{array}{l}74.0 \\
39.0 \\
72.0 \\
54.0 \\
57.6 \\
74.1\end{array}$ \\
\hline \multicolumn{15}{|c|}{ Subsurface } \\
\hline 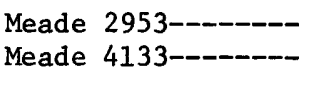 & $\begin{array}{l}54.7 \\
35.9\end{array}$ & $\begin{array}{l}36.0 \\
22.3\end{array}$ & $\begin{array}{l}7.7 \\
7.0\end{array}$ & $\begin{array}{l}0.0 \\
0.0\end{array}$ & $\begin{array}{l}5.4 \\
5.4\end{array}$ & $\begin{array}{l}4.3 \\
6.3\end{array}$ & $\begin{array}{l}24.0 \\
27.6\end{array}$ & $\begin{array}{l}0.3 \\
4.0\end{array}$ & $\begin{array}{l}18.7 \\
13.3\end{array}$ & $\begin{array}{r}5.0 \\
10.3\end{array}$ & $\begin{array}{l}6.7 \\
2.7\end{array}$ & $\begin{array}{r}6.0 \\
20.4\end{array}$ & $\begin{array}{l}9.6 \\
6.8\end{array}$ & $\begin{array}{l}77.7 \\
70.1\end{array}$ \\
\hline $\begin{array}{ll}\text { Wolf Creek } & 1-867-- \\
\text { Wolf Creek } & 3-1553- \\
\text { Wolf Creek } & 3-2050- \\
\text { Wolf Creek } & 3-2532- \\
\text { Wolf Creek } & 3-3109- \\
\text { Wolf Creek } & 3-3509-\end{array}$ & $\begin{array}{l}43.8 \\
69.1 \\
47.9 \\
45.0 \\
39.2 \\
28.7\end{array}$ & $\begin{array}{l}20.1 \\
48.2 \\
27.1 \\
22.0 \\
24.9 \\
20.0\end{array}$ & $\begin{array}{r}.7 \\
.3 \\
5.7 \\
3.3 \\
2.7 \\
3.7\end{array}$ & $\begin{array}{r}0.0 \\
.3 \\
.3 \\
0.0 \\
.3 \\
.3\end{array}$ & $\begin{array}{r}2.0 \\
3.3 \\
7.4 \\
1.3 \\
.3 \\
1.0\end{array}$ & $\begin{array}{r}21.4 \\
4.3 \\
5.0 \\
12.0 \\
.7 \\
1.0\end{array}$ & $\begin{array}{l}27.4 \\
20.6 \\
23.8 \\
26.0 \\
15.3 \\
13.0\end{array}$ & $\begin{array}{r}0.0 \\
0.0 \\
1.0 \\
1.0 \\
.7 \\
3.0\end{array}$ & $\begin{array}{r}23.4 \\
20.6 \\
19.8 \\
22.0 \\
14.3 \\
8.7\end{array}$ & $\begin{array}{r}4.0 \\
0.0 \\
3.0 \\
3.0 \\
.3 \\
1.3\end{array}$ & $\begin{array}{r}0.0 \\
14.6 \\
2.0 \\
0.0 \\
0.0 \\
0.0\end{array}$ & $\begin{array}{r}11.4 \\
3.7 \\
24.4 \\
22.9 \\
35.9 \\
42.0\end{array}$ & $\begin{array}{r}13.0 \\
3.7 \\
2.7 \\
2.7 \\
16.3 \\
16.4\end{array}$ & $\begin{array}{l}75.6 \\
78.0 \\
70.9 \\
74.4 \\
47.8 \\
41.6\end{array}$ \\
\hline
\end{tabular}


Oumalik 979-84-_--

Oumalik 1606-----

Oumalik 3260-_-_.

Oumalik 3752.5-...

Knifeblade 2A-172-

Knifeblade 2A-792-

Knifeblade 2A-1557

Kaolak 937-_.

Kaolak 2453-_-.----

Kaolak 3187

Kaolak 4078-_-_-

Simpson 454-_-

Simpson 829--

Simpson 979

Grandstand 364-69Grandstand 862-82Grandstand 2484---

Topagoruk 304- - Topagoruk 603-----

Topagoruk 1204----

Topagoruk 1790-_--

Titaluk 539------

Titaluk 2675-_-...

Titaluk 3004-_-_--

Titaluk 3306-----

Titaluk 3431-_-_--

Gubik 3112-- - -

Gubik 3529-------

Gubik 3645--_----

Gubik 3822--.----

Gubik 4243

Square Lake 1685-Square Lake 1854-Square Lake 1916-Square Lake 3036Square Lake 3480-Square Lake 3856--

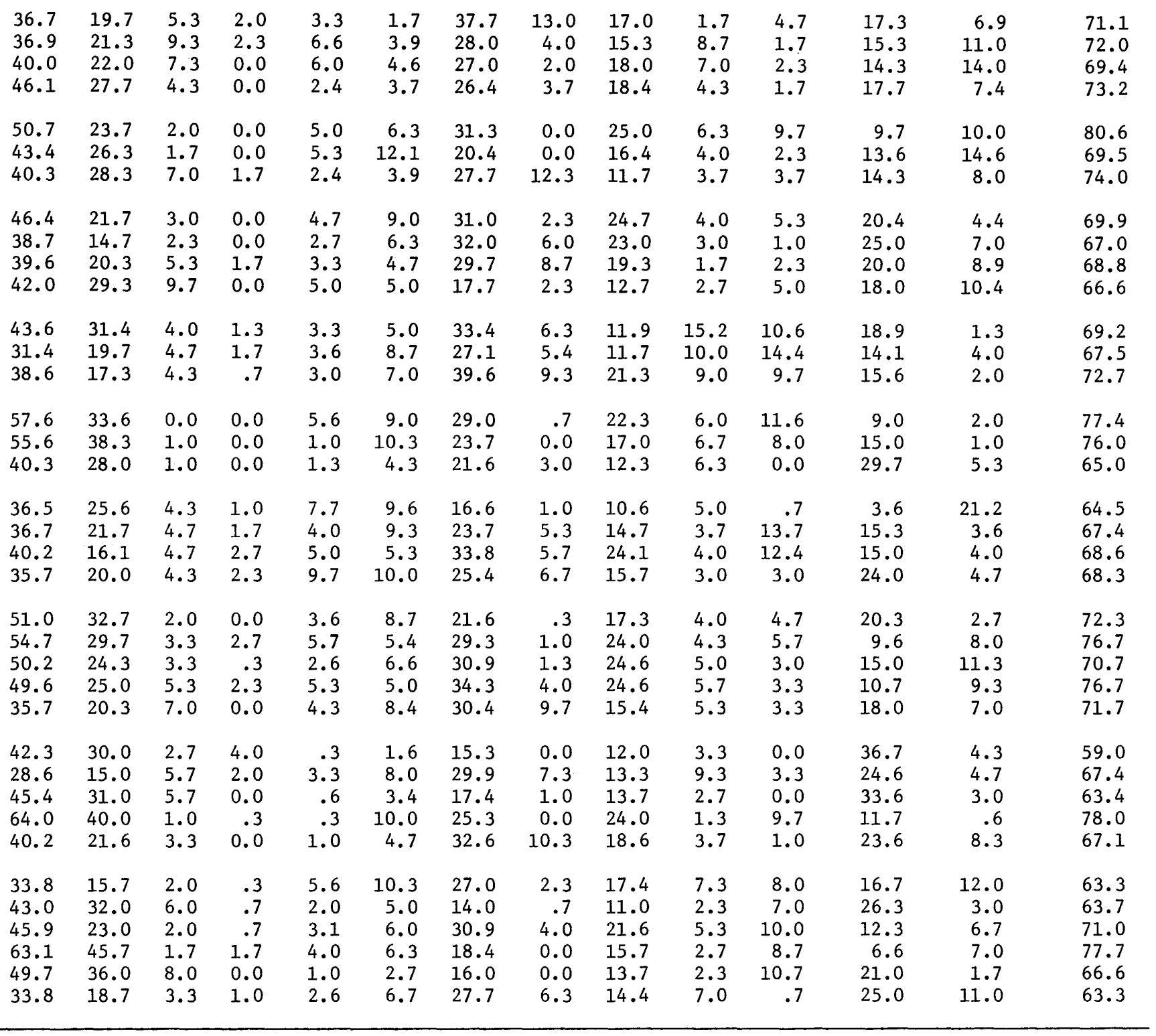


(Oriented mounts were made to aid in identification of the clay minerals; glycolation, potassium-acetate intersalation, and various heating techniques were incorporated (amounts estimated in parts per ten); Paul D. Blackmon and Harry C. Starkey, analysts. Leaders (---) indicate none present]

\begin{tabular}{|c|c|c|c|c|c|c|c|c|c|}
\hline \multirow[b]{2}{*}{$\begin{array}{l}\text { Sample } \\
\text { No. }\end{array}$} & \multicolumn{9}{|c|}{ Clay types } \\
\hline & I1lite & $\begin{array}{l}\text { I1lite-mica } \\
\text { or mica }\end{array}$ & $\begin{array}{l}\text { Illite- } \\
\text { montmorillonite, } \\
\text { mixed }\end{array}$ & $\begin{array}{l}\text { Montmoril- } \\
\text { lonite }\end{array}$ & $\begin{array}{l}\text { Chlorite- } \\
\text { montmorillonite, } \\
\text { mixed }\end{array}$ & Chlorite & $\begin{array}{l}\text { Mica- } \\
\text { chlorite, } \\
\text { mixed }\end{array}$ & Kaolinite & Serpentine \\
\hline \multicolumn{10}{|c|}{ Surface } \\
\hline 1075----- & -- & 4 & -- & --- & $\ldots$ & 5 & --- & --- & --- \\
\hline 1175 & --- & $4+$ & -- & --- & -- & $4+$ & -- & $\ldots$ & -- \\
\hline $1275---\infty-$ & $-\cdots$ & $3+$ & -- & --- & -- & $2+$ & --- & $2+$ & --- \\
\hline $1475-$ & --- & 5 & -- & --- & --- & 1 & --- & 1 & --- \\
\hline $1575--$ & --- & 5 & --- & --- & --- & 2 & -- & $1+$ & --- \\
\hline 1875----- & --- & $3+$ & -- & Trace & --- & $2+$ & -- & $2+$ & --- \\
\hline 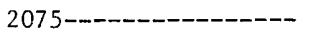 & --- & $2+$ & $-\infty$ & 1 & --- & $2+$ & -- & $2+$ & -- \\
\hline 2175 & -- & $3+$ & --- & $1-$ & -- & $2+$ & --- & $1+$ & --- \\
\hline $2675-$ & --- & $1+$ & --- & -- & --- & $1+$ & --- & -- & $4+$ \\
\hline $3075-$ & --- & $3+$ & --- & --- & 2 & $2+$ & --- & -- & -- \\
\hline 3275------ & $-\infty$ & 2 & -- & --- & --- & 2 & -- & -- & $3+$ \\
\hline 3375 & -- & $1+$ & --- & Trace & --- & $1+$ & 1 & $1-$ & -- \\
\hline $3675-$ & --- & $1+$ & -- & $1-$ & $-m$ & $1-$ & $\ldots$ & $1+$ & --- \\
\hline 3875- & -- & $1+$ & --- & Trace & --- & 1 & --- & --- & $3+$ \\
\hline 4275- & --- & $1+$ & --- & --- & --- & $1-$ & -- & 5 & --- \\
\hline 4375------- & -- & 2 & 1 & -- & -- & Trace & --- & $4+$ & --- \\
\hline 4575- & --- & $2+$ & --- & -- & --- & $1-$ & -- & $3+$ & --- \\
\hline 4875-0- & -- & 1 & $1-$ & --- & -- & Trace & --- & $5+$ & -- \\
\hline 5175-----1--1- & --- & It & Trace & --- & -- & Trace & -- & 4 & --- \\
\hline 5375---_----------- & -- & $1+$ & $1+$ & --- & -- & Trace & -- & $3+$ & --- \\
\hline $5475-$ & --- & $1-$ & $1-$ & --- & --- & Trace & --- & $5+$ & -- \\
\hline \multicolumn{10}{|c|}{ Subsurface } \\
\hline Kaolak 1-937-_... & -1 & --- & -- & Trace & -- & Trace & -- & Trace & --- \\
\hline Kaolak 1-2453------ & $1+$ & --- & -- & --- & --- & Trace & --- & -1 & --- \\
\hline Kaolak 1-3187------- & 1 & -- & Trace & --- & --- & Trace & --- & -1 & -- \\
\hline Kaolak 1-4078 & -1 & -- & Trace & --- & --- & Trace & --- & 1 & -- \\
\hline Kaolak 1-6739-_-_- & -1 & --- & Trace & --- & --- & Trace & --- & Trace & --- \\
\hline
\end{tabular}


Topagoruk 1-304p----

Topagoruk 1-603p----

Topagoruk 1-1204p--

Topagoruk 1-1790p---
Topagoruk 1-5972----

$-1$

Topagoruk 1-6498-----

Simpson 454--------Simpson 829-.---.-

Simpson $979-2$

Trace

Oumalik 1-979p-----Oumalik 1-1606p-.... - -

Titaluk 1-539p-----Titaluk 1-2675p---.- Trace Titaluk 1-3004p----- -1

Wo1f Creek 1-867---Wo1f Creek 3-1553--Wolf Creek 3-2050---

Wo1f Creek 3-2532---

Wolf Creek 3-3109---

Grandstand 364-69--Grandstand 862-82--

Knifeblade 2A-172pKnifeblade 2A-792p--

Knifeblade 2A-1557n-

Square Lake 1685---Square Lake 1854---Square Lake 1916---Square Lake 3036----Square Lake 3480----Square Lake 3856----

Gubik 2-3112-------Gubik 2-3529--.----- 
Appendix 4.--List of porosity and permeability data from the subsurface samples studied (Robinson, 1956, 1958a, b, C, 1964; Collins, 1958b, c, 1959)

\begin{tabular}{|c|c|c|c|c|c|c|c|c|c|}
\hline $\begin{array}{l}\text { Test } \\
\text { we11 }\end{array}$ & $\begin{array}{l}\text { Depth } \\
(f t)^{1}\end{array}$ & $\begin{array}{l}\text { Effective } \\
\text { porosity }\end{array}$ & $\underset{\text { permeability }}{\text { Air }}$ & $\begin{array}{l}\text { Presence } \\
\text { of coal }{ }^{3}\end{array}$ & $\begin{array}{l}\text { Test } \\
\text { well }\end{array}$ & $\begin{array}{l}\text { Depth } \\
(\mathrm{ft})^{1}\end{array}$ & $\begin{array}{l}\text { Effective } \\
\text { porosity }\end{array}$ & $\underset{\text { permeability }}{\text { Air }}$ & $\begin{array}{l}\text { Presence } \\
\text { of coal }{ }^{3}\end{array}$ \\
\hline Meade-------- & $2,953(p)$ & 19.2 & 13.48 & --- & Titaluk--_-_- & $539(p)$ & 12.0 & Imp. & --- \\
\hline Meade-_- & $2,953(n)$ & 13.7 & 9.54 & -- & Titaluk----- & $539(n)$ & 11.7 & n.a. & -- \\
\hline \multirow{2}{*}{ Meade-- - - } & 4,133 & 9.35 & Imp. & --- & Titaluk------ & $2,675(p)$ & 12.45 & 17.0 & $-\infty$ \\
\hline & & & & & Titaluk-- - & $2,675(n)$ & 11.3 & 8.0 & --- \\
\hline Wolf Creek 1- & 867 & 5.31 & Imp. & -- & Titaluk-- - & $3,004(p)$ & 8.25 & Imp. & -- \\
\hline Wolf Creek 3- & 1,553 & 18.88 & 305.00 & --- & Titaluk-..-- & $3,004(n)$ & 9.96 & n.a. & -- \\
\hline Wolf Creek 3- & 2,050 & 10.6 & $<1$ & -- & Titaluk------ & $3,306(p)$ & 8.98 & Imp. & --- \\
\hline Wolf Creek 3- & 2,532 & 4.73 & $\operatorname{Imp}$ & -- & Titaluk--.-- & $3,306(n)$ & 8.83 & n.a. & --- \\
\hline Wolf Creek 3- & 3,109 & 2.4 & Imp. & --- & Titaluk----- & $3,431(p)$ & 10.5 & Imp. & --- \\
\hline Wolf Creek 3- & 3,509 & 5.5 & Imp. & --- & Titaluk- - & $3,431(n)$ & 12.0 & n.a. & -- \\
\hline Oumalik------ & 979-984 & 15.2 & 34.0 & -- & Gubik-_----- & 3,112 & 10.6 & Imp. & -- \\
\hline Oumalik------ & $1,606(p)$ & 10.9 & 8.8 & -- & Gubik------- & 3,529 & 13.46 & 2.3 & --- \\
\hline Oumalik_-_... & 3,260 & 9.2 & $<4$ & --- & Gubik------- & 3,645 & 10.36 & Imp. & --- \\
\hline \multirow[t]{2}{*}{ Oumalik---- } & $3,752.5$ & 12.0 & $<1$ & --- & Gubik-_----- & 3,822 & 14.07 & 22.0 & --- \\
\hline & & & & & Gubik-------- & 4,243 & 10.35 & Imp. & -- \\
\hline Knifeblade 2A & 172 & 41.0 & n.a. & $x$ & & & & & \\
\hline Knifeblade $2 \mathrm{~A}$ & 792 & 14.2 & 1.3 & $\mathrm{x}$ & Square Lake-- & 1,685 & 18.3 & 28.0 & -- \\
\hline \multirow[t]{2}{*}{ Knifeblade $2 \mathrm{~A}$} & 1,557 & 11.56 & $<1$ & $\mathrm{x}$ & Square Lake-- & 1,854 & 13.5 & $<1$ & -- \\
\hline & & & & & Square Lake-- & 1,916 & 17.5 & n.a. & -- \\
\hline Kaolak------- & 937 & 11.55 & $\operatorname{Imp}$ & --- & Square Lake-- & 3,036 & 13.3 & 17.6 & -- \\
\hline Kaolak------ & 2,453 & 11.90 & Imp. & $\mathrm{x}$ & Square Lake-- & 3,480 & 12.7 & Imp. & -- \\
\hline Kaolak------ & 3,187 & 10.04 & $\operatorname{Imp}$. & -- & Square Lake-- & 3,856 & 8.9 & Imp. & $-\cdots$ \\
\hline Kaolak------- & 4,078 & 11.28 & Imp. & -- & & & & & \\
\hline
\end{tabular}

\begin{tabular}{|c|c|c|c|c|}
\hline Simpson----- & 454 & 31.4 & n.a. & -- \\
\hline Simpson------ & 829 & 28.8 & n.a. & -- \\
\hline Simpson-m--- & 979 & 30.3 & n.a. & -- \\
\hline Grandstand--- & $364-369$ & 10.6 & n.a. & --- \\
\hline Grandstand--- & $862-882$ & 11.15 & $<1$ & -- \\
\hline Grand stand--- & 2,484 & 5.02 & Imp. & \\
\hline Topagoruk---- & $304(p)$ & 11.0 & 5.17 & -- \\
\hline Topagoruk---- & $304(n)$ & 11.1 & $\operatorname{Imp}$ & - \\
\hline Topagoruk---- & $603(p)$ & 27.2 & 316.2 & -- \\
\hline Topagoruk--- & $603(n)$ & 26.2 & 219.8 & -- \\
\hline Topagoruk---- & $1,204(p)$ & 26.0 & 200.4 & --- \\
\hline Topagoruk---- & $1,204(n)$ & 23.1 & 128.9 & -- \\
\hline Topagoruk---- & 1,790 & 18.1 & 11.8 & \\
\hline
\end{tabular}

$1(p)$, test plug made to determine permeability parallel to bedding; $(n)$, test plug made to determine permeability perpendicular to bedding.

${ }^{2}$ Imp., impermeable; n.a., not analyzed.

3---, none present; $x$, present.

1,790

18.1 
STRATIGRAPHY AND PETROGRAPHY OF A

MEASURED SECTION ON THE SOUTH LIMB OF

BARABARA SYNCLINE, NORTH SLOPE, ALASKA

By A. Curtis Huffman, Jr.

\section{INTRODUCTION}

This paper discusses the stratigraphy and petrography of the middle portion of the Lower and Upper(?) Cretaceous Nanushuk Group, with emphasis on those properties affecting oil and gas reservoir potential as well as uranium host-rock potential. The longest and best exposed outcrop of this part of the Nanushuk Group measured during the 1977 field season was on the south limb of Barabara Syncline. The section was measured along the Kukpowruk River from $69^{\circ} 24^{\prime} 46^{\prime \prime} \mathrm{N}$. and $162^{\circ} 40^{\prime} 58^{\prime \prime} \mathrm{W}$. to $69^{\circ} 25^{\prime} 17^{\prime \prime}$ N. and $162^{\circ} 41^{\prime} 46^{\prime \prime}$ W. (fig. 36), a distance of $3.25 \mathrm{~km}$ and a stratigraphic thickness of 1,424 $\mathrm{m}$. Exposure in this interval was nearly 100 percent; Chapman and Sable (1960, p1. 11), however, measured an additional 1,000 $\mathrm{m}$ of very poorly exposed nonmarine sediments downstream from this section.

This section was selected for detailed petrographic and stratigraphic study for the following reasons: (1) the outcrop is long and very wel1 exposed; (2) it was the northernmost section measured; (3) it lies along the general sediment-transport direction (Ahlbrandt and others, this volume), approximately halfway between the Corwin Bluff section to the southwest and the Kaolak test well to the northeast (the closest subsurface information on the Corwin delta); and (4) it includes a thick transitional zone between marine and nonmarine sedimentary sequences which is characteristic of the Corwin delta.

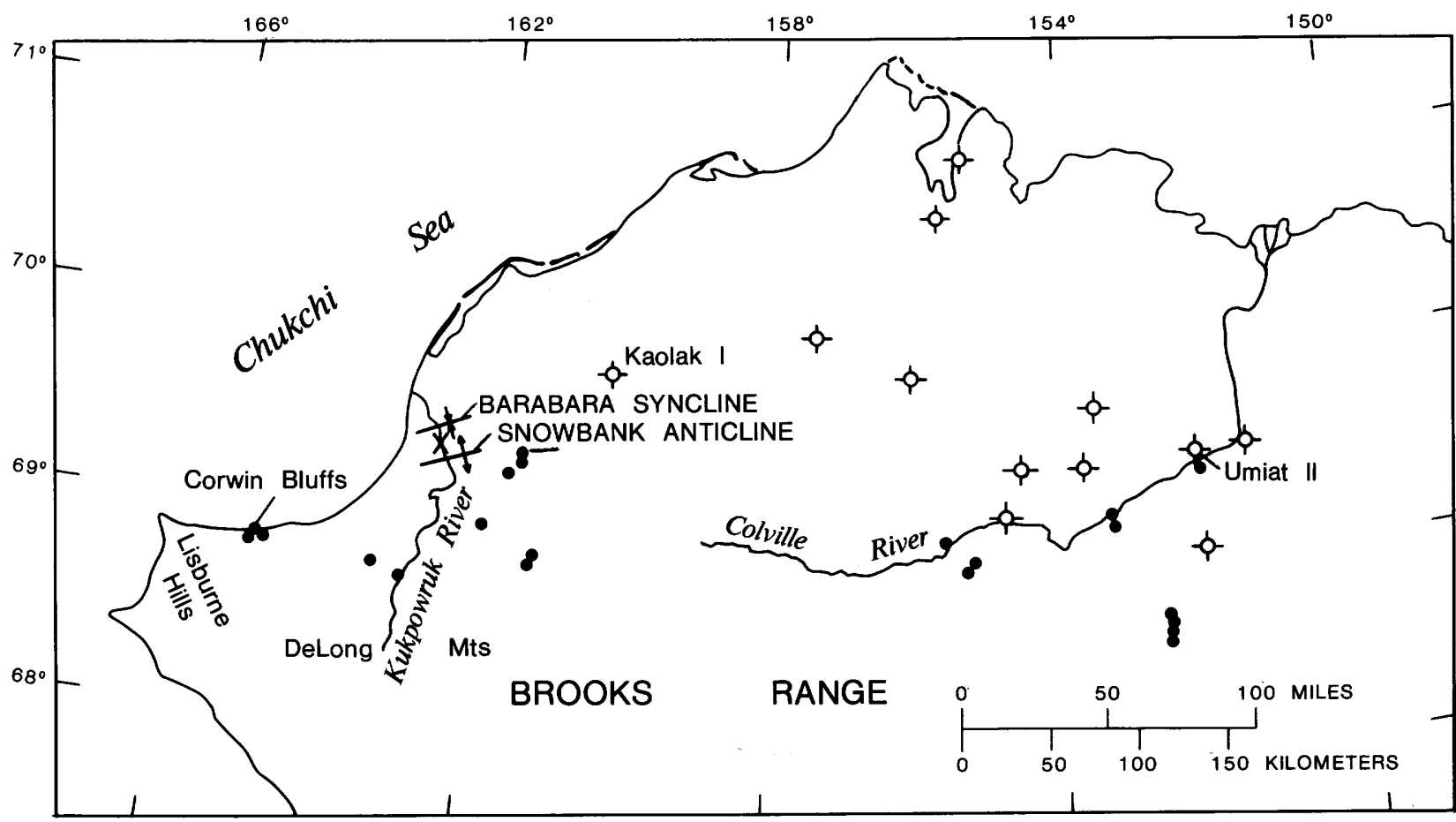

Figure 36.--Index map showing locations of the south limb of Barabara Syncline (x), the test wells (crossed open circle), and surface samples (solid dot) discussed by Bartsch-Winkler (this volume). 
By selecting this section for study in detail, a preliminary comparison can be made between the Corwin delta and the Umiat delta, which was studied in comparable detail in Umiat test wel1 11 (Fox and others, 1979; Fox, this volume). The section described includes the Kukpowruk and Corwin Formations and corresponds approximately to the Grandstand Formation and lower part of the Killik Tongue of the Chandler Formation of the Umiat 11 well.

\section{STRATIGRAPHY}

The sequence of Lower Cretaceous rocks exposed on the south limb of Barabara Syncline is very similar to that measured throughout the western portion of the North Slope. This sequence has been interpreted by Ahlbrandt and others (this volume) to have been deposited in a deltaic environment. Such an interpretation is consistent with the results of this detailed study; however, the specific type of delta is somewhat questionable, as discussed in Ahlbrandt and others (this volume). The lower marine portion of the Nanushuk Group was not measured in this section, but the thick transitional and nonmarine portions seem to have been deposited in a river-dominated delta system.

The measured section originated $410 \mathrm{~m}$ downstream (north) from the approximate axis of Snowbank Anticline along the Kukpowruk River. At the base of the section, the bedding strikes N. $80^{\circ}$ E. and dips $56^{\circ}$ northwest along the western bank of the river; it appears to have a much shallower dip along the eastern bank, indicating the presence of minor structures. Exposures between the base of the section and the core of the anticline are very poor and nearly flat-1ying; however, they appear to be composed entirely of marine sandstones and shales. From the base of the section northward, structural complexity is minimal and dips decrease regularly away from the anticline.

The stratigraphic section on the south limb of Barabara Syncline was measured using a combination of tape and jacob-staff methods. The sandstone intervals were described on a meter by meter basis, whereas the shale intervals, although measured by the same methods, were described in much less detail. Sampling for porosity and permeability determinations and for petrographic study was not systematic; rather, it concentrated on the coarser grained, thicker sandstones, which are of greater interest from a petroleum reservoir standpoint. Thirty-four samples were taken from a total of 154 sandstone beds. The thicker beds were frequently sampled at several horizons.

The basal $90 \mathrm{~m}$ of the section is composed entirely of marine sandstone, shale, and several thin siltstone intervals. The shale is dark greenish gray to black and is virtually identical to the marine shale of the Torok Formation of Early Cretaceous age, which underlies the Nanushuk Group. Fossils recovered from the shale include both marine pelecypods and abundant burrows parallel to bedding. Sandstones compose 14 percent of the section and are generally thin (less than $2 \mathrm{~m}$ ), with the thickest being $6 \mathrm{~m}$. They are light olive gray to pale yellowish brown, very fine to fine grained, and moderately well to well sorted; they have very sparse burrowing and commonly contain plant debris and carbonaceous material on the bedding planes. Most of these sandstones are both symmetrically and asymmetrically rippled; the thickest bed also contains low- to moderateangle planar crossbedded sets as thick as 15 cm.

Above the basal marine section is a $480-\mathrm{m}-$ thick sequence of alternating nearshore-marine and nonmarine sandstones and shales. This thick transitional zone is characteristic of the Corwin delta and contains not only the highest percentage of sandstone (26 percent) but also over 50 percent of the total sandstone in this section. The sandstone beds are generally thicker in this interval than in the remainder of the section. They average almost $3 \mathrm{~m}$, and some beds are as much as $14 \mathrm{~m}$.

Several distinctive environments are represented in the transitional zone. They include (1) marine (foreshore, shoreface, and prodelta); (2) estuarine or lagoonal; and (3) nonmarine (channel, overbank, and lacustrine). Various combinations of these environments alternate in 40- to 80-m-thick, coarseningupward cycles that generally begin with black marine shales at the base and progress upward into thin siltstone beds, shoreface sands, and foreshore sands, which may or may not be capped by nonmarine deposits. The marine sediments dominate the lower transition zone, with the nonmarine becoming increasingly abundant upward. The marine sandstones in the transitional zone are generally light brownish gray to pale yellowish brown, very fine to fine grained, thin to very thin bedded, and moderately well to well sorted. They are calcareous and contain plant debris and carbonaceous material on bedding planes. Sedimentary structures are variable, depending on the environment of deposition, as are the fossil and trace-fossil content. The shoreface sandstones are characterized by contorted bedding, trough and lowto moderate-angle planar crossbedding, ripples, and a variety of trace fossils. Foreshore sandstones are flat bedded to low angle planar crossbedded and contain sparse trace fossils, most commonly skolithos and Diplocraterion, and abundant root tubes. The dark-greenish-gray to black marine shales are commonly rippled and have abundant trace fossils on the bedding planes. Marine pelecypods, though not common, are more plentiful in the shales than in the sandstones.

Nonmarine deposits in the transitional zone vary from thin (less than $1 \mathrm{~m}$ ) carbonaceous shale beds in a predominantly marine sequence to 55-m-thick sequences of carbonaceous shale, 
fluvial-channel sandstones, and lacustrine shale and siltstone deposits. The carbonaceous shale is medium gray to dark greenish gray and silty; it often contains leaf and stem imprints as well as abundant plant debris. The fluvial sandstones are predominantly of braided-channel and probable crevasse-splay origin; they are light gray to 1ight olive gray, fine to medium grained, moderately well to well sorted, very thin to medium bedded, and trough crossbedded and rippled. Carbonaceous material and plant fragments are abundant in the sandstones, and well-preserved leaf and stem imprints are common in the finer grained beds within the transitional zone.

The nonmarine portion of the section at this locality exceeds $860 \mathrm{~m}$ in thickness and consists of predominantly carbonaceous shale and thin sandstone beds. Chapman and Sable (1960, pl. 11) reported a total nonmarine section of over $2,276 \mathrm{~m}$, but much of this was covered. The total amount of sandstone in the measured $860 \mathrm{~m}$ is very small (less than 12 percent) and the individual sandstone beds are generally very thin, averaging less than $1.5 \mathrm{~m}$; however, the thickest single sandstone body in the entire section occurs in the nonmarine section $58 \mathrm{~m}$ above the base. This 25-m-thick unit is predominantly pale-yellowish-brown, medium- to fine-grained, moderately well sorted, medium-bedded to very thin bedded, troughcrossbedded, calcareous sandstone. Also included are flat-bedded, asymmetrically rippled sequences and a number of channel lag deposits that are predominantly clay rip-up fragments and carbonaceous material. The unit is composed of several fining-upward sequences beginning with coarse-grained lag deposits and ending with clay drapes. This thick unit was most likely deposited by a meandering stream, interpreted as being the major distributary in this portion of the delta primarily because of the thickness and large amount of coarse-grained material.

Twenty-four coal beds were measured that have a total thickness of $21 \mathrm{~m}$ or 2.4 percent of the nonmarine portion of the section. The thickest bed was $3 \mathrm{~m}$ and several were between 1 and $2 \mathrm{~m}$ thick. The coal, although not yet analyzed, is of generally low rank and is commonly interbedded with carbonaceous shale and siltstone. The marshes and swamps on the delta plain were evidently of fairly short duration and somewhat limited extent.

\section{PETROGRAPHY}

\section{Methods}

Standard thin sections were cut from each sample, with one half of each section being stained with Alizarin Red S to detect calcite and the other, with sodium cobaltinitrite to detect potassium feldspars. Each sample was also injected with blue plastic to enhance the pores.
The petrographic analysis was conducted according to the methods discussed by Dickinson (1970). Three hundred points per thin section were counted. The percentages of 27 compositional variables were determined and combined into the 12 categories presented in table 5 . By variously combining these parameters, the data can be represented in either the Dickinson (1970) (fig. 37) or Folk (1968) (fig. 38) classification systems.

Textural observations made during the petrographic study included maximum and modal grain size, sorting, roundness, and types of grain contacts. Grain size was determined by measuring the long axis of individual clasts, and sorting was calculated on the basis of these measurements. Roundness was estimated by comparison with the Krumbein (1941) visual estimator. Porosity and permeability measurements were conducted on each sample and are reported with the textural data in table 6 .

The uranium and thorium content of each sample was determined by the delayed-neutron method and is reported in table 7 . Field measurements of radioactivity were made with a ratemeter for most of the thicker sandstone beds, as well as for some of the coal seams and a few shale intervals.

\section{Results}

Thirty-four samples from the measured section and two from the trough of Barabara Syncline were studied. The results of these analyses are presented in tables 5 and 6 . The following description is presented in such a manner as to facilitate comparison with the description of Umiat test well 11 (Fox and others, 1979), which is summarized by Fox (this volume). The measured section described here roughly corresponds to the Lower Cretaceous Grandstand Formation and lower part of the Killik Tongue of the Chandler Formation in the report by Fox and others (1979). (See, for example, Chapman and Sable, 1960, fig. 12, for an approximate correlation.)

The samples from the south limb of Barabara Syncline show 1ittle lithologic variation. They are 1ight-gray to pale-yellowish-brown, well-sorted to moderately well sorted, very fine grained to medium-grained chert and shale-arenites and calc-lithites. Lithic fragments contain chert and polycrystalline quartz, argillaceous and carbonaceous fragments, and recrystallized calcite. They constitute an average of 38 percent of each sample, and the percentage of cement, primarily calcite, varies from 4 to 50. The detrital grains are subrounded to subangular, and grain contacts vary from smooth and concavo-convex to those with some suturing and evidence of presolution. The softer argillaceous-carbonaceous clasts are commonly deformed and squeezed between the framework grains, thus filling the pore spaces and greatly reducing the porosity and permeability. 
Table 5.--Composition of samples from the south limb of Barbara Syncline

[Modal percentages based on 300 points per thin section; L, M, or U following sample numbers indicates lower, middle, or upper sample from one sandstone unit; Qm, monocrystalline quartz; Pq, polycrystalline quartz (less quartzite); Lv, volcanic 1ithic fragments; $\mathrm{Lm}$, metamorphic 11th1c fragments; Ls, sedimentary 11th1c fragments; Ac, Argillaceous and carbonaceous; leaders (---) indicate none observed]

\begin{tabular}{|c|c|c|c|c|c|c|c|c|c|c|c|c|c|}
\hline $\begin{array}{c}\text { Sample } \\
\text { No. }\end{array}$ & $\begin{array}{l}\text { Total } \\
\text { quartz }\end{array}$ & $\mathrm{Qm}$ & $\mathrm{Pq}$ & Feldspar & Lv & Lm & Ls & $\mathrm{Ac}$ & $\begin{array}{l}\text { Calcite } \\
\text { clast }\end{array}$ & Matrix & Cement & Mica & $\begin{array}{c}\text { Other heavy } \\
\text { minerals }\end{array}$ \\
\hline \multicolumn{14}{|l|}{ 77AAH: } \\
\hline 184 & 63.3 & 22.3 & 39.7 & 2.6 & 2.7 & 1.6 & 49.3 & 9.6 & --- & 1.6 & 4.4 & --- & 0.6 \\
\hline 183 & 49.0 & 37.3 & 11.4 & 7.6 & 4.7 & 1.3 & 21.0 & 7.3 & 2.3 & 10.3 & 12.7 & .3 & .6 \\
\hline \multicolumn{14}{|l|}{ 77ACH: } \\
\hline 129 & 28.6 & 21.6 & 6.7 & 5.3 & 1.0 & 1.3 & 18.3 & 7.3 & 4.3 & .3 & 50.7 & .6 & .6 \\
\hline 127 & 38.0 & 13.7 & 24.3 & 5.0 & 3.3 & 2.4 & 39.9 & 12.6 & 3.0 & 4.0 & 30.3 & .3 & .6 \\
\hline 126 & 34.0 & 23.6 & 9.4 & 6.0 & 3.7 & 1.6 & 20.0 & 8.3 & 2.3 & 1.0 & 43.3 & -- & .6 \\
\hline 123 & 47.3 & 32.3 & 14.7 & 8.6 & 3.6 & .6 & 33.0 & 15.3 & 3.0 & 9.0 & 11.0 & --- & 1.0 \\
\hline $120 \mathrm{U}$ & 25.0 & 13.0 & 11.7 & 3.3 & 1.6 & 2.0 & 39.0 & 3.3 & 24.0 & 9.3 & 30.3 & 1.0 & --- \\
\hline $120 \mathrm{~L}$ & 34.6 & 20.0 & 13.6 & 3.3 & .3 & 1.0 & 58.6 & 13.0 & 32.0 & 3.0 & 14.6 & -- & .6 \\
\hline 116 & 50.3 & 22.6 & 26.3 & 4.3 & .3 & 1.3 & 41.3 & 14.0 & 1.0 & 9.3 & 17.3 & --- & 3.3 \\
\hline 113 & 25.3 & 22.3 & 3.0 & 3.3 & -- & - & 42.0 & 9.0 & 30.0 & 8.3 & 22.3 & 1.6 & -- \\
\hline 110 & 24.6 & 11.3 & 13.3 & 3.0 & 3.3 & - & 42.6 & 17.0 & 12.3 & 5.3 & 32.7 & .6 & 1.0 \\
\hline $108 \mathrm{U}$ & 40.6 & 26.6 & 14.0 & 6.6 & 1.3 & --- & 31.7 & 13.6 & 4.1 & 8.9 & 21.7 & -- & 1.6 \\
\hline $108 \mathrm{M}$ & 40.6 & 25.3 & 15.3 & 7.3 & .3 & --- & 31.6 & 13.0 & 3.3 & 5.3 & 27.3 & .3 & 2.3 \\
\hline $108 \mathrm{~L}$ & 38.6 & 27.3 & 11.3 & 7.6 & .6 & --- & 32.0 & 17.3 & 3.4 & 8.0 & 21.6 & -- & 2.6 \\
\hline $104 \mathrm{U}$ & 56.6 & 39.3 & 17.3 & 12.0 & 1.0 & -- & 27.6 & 8.6 & 1.7 & 2.0 & 13.3 & -- & 3.3 \\
\hline $104 \mathrm{~L}$ & 50.0 & 42.0 & 8.0 & 10.3 & 2.0 & -- & 21.0 & 11.7 & 1.3 & 8.0 & 14.6 & -- & .6 \\
\hline 1010 & 42.6 & 31.6 & 11.0 & 7.6 & 1.6 & -- & 31.4 & 17.7 & 2.7 & 5.0 & 21.3 & --- & 1.3 \\
\hline $101 \mathrm{M}$ & 42.3 & 37.3 & 5.0 & 5.6 & 2.3 & -- & 26.0 & 19.0 & 2.0 & 7.3 & 19.0 & -- & 1.0 \\
\hline $101 \mathrm{~L}$ & 45.0 & 36.3 & 8.7 & 7.3 & 1.3 & -- & 30.0 & 17.3 & 4.0 & 6.3 & 14.3 & 1.0 & 2.0 \\
\hline 100 & 42.6 & 30.3 & 12.3 & 10.6 & 2.0 & -- & 33.6 & 10.0 & 11.3 & 5,0 & 16.0 & $\cdots$ & 2.3 \\
\hline $98 \mathrm{U}$ & 34.6 & 21.3 & 13.3 & 5.6 & 1.3 & -- & 38.3 & 13.7 & 11.3 & 5.7 & 22.6 & .6 & 4.3 \\
\hline $98 \mathrm{~L}$ & 34.0 & 22.0 & 12.0 & 7.3 & 3.0 & --- & 34.0 & 16.3 & 5.7 & 8.0 & 20.0 & .3 & 2.0 \\
\hline 97 & 48.0 & 29.0 & 19.0 & 12.0 & 2.0 & -- & 35.0 & 12.3 & 3.7 & 4.6 & 16.0 & -- & 1.3 \\
\hline $93 \mathrm{U}$ & 58.3 & 26.7 & 31.6 & 8.6 & 3.0 & -- & 41.9 & 9.7 & .6 & 6.3 & 11.3 & .6 & 1.3 \\
\hline $93 \mathrm{M}$ & 53.6 & 29.0 & 24.6 & 9.3 & 5.3 & -- & 36.9 & 10.7 & 1.6 & 6.0 & 11.6 & .3 & .6 \\
\hline $93 \mathrm{~L}$ & 43.0 & 20.7 & 22.3 & 8.6 & 3.0 & -- & 43.3 & 18.0 & 3.0 & 10.0 & 13.0 & -- & 1.3 \\
\hline 92 & 51.0 & 26.3 & 24.4 & 12.6 & 4.0 & .3 & 34.4 & 10.0 & -- & 7.0 & 11.6 & .3 & .3 \\
\hline 900 & 52.6 & 32.3 & 20.0 & 10.0 & 3.3 & .3 & 35.7 & 15.7 & --- & 6.6 & 10.0 & .3 & .6 \\
\hline $90 \mathrm{~L}$ & 55.7 & 31.0 & 24.7 & 10.6 & 5.0 & .3 & 37.0 & 12.3 & --- & 6.6 & 6.0 & -- & 2.0 \\
\hline $89 u$ & 52.0 & 28.0 & 23.3 & 7.6 & 5.0 & -- & 37.3 & 14.0 & --- & 7.0 & 10.0 & $-\cdots$ & 1.3 \\
\hline $89 \mathrm{~L}$ & 49.0 & 28.3 & 20.7 & 9.3 & 8.0 & -- & 34.7 & 11.0 & 3.0 & 8.7 & 10.3 & --- & .6 \\
\hline $87 U$ & 44.6 & 25.3 & 19.3 & 12.6 & 6.6 & -- & 36.3 & 15.7 & 1.3 & 9.7 & 7.5 & --- & .6 \\
\hline $87 \mathrm{~L}$ & 54.7 & 28.0 & 26.7 & 7.6 & 6.6 & -- & 42.3 & 15.6 & - & 8.6 & 5.0 & -- & 1.0 \\
\hline 85 & 63.3 & 34.3 & 29.0 & 12.0 & 3.0 & -- & 36.3 & 6.7 & .6 & 4.6 & 9.0 & -- & -- \\
\hline 83 & 48.6 & 30.6 & 18.0 & 13.3 & 4.0 & -- & 27.3 & 7.0 & 2.3 & 9.3 & 8.9 & --- & 1.0 \\
\hline 82 & 51.3 & 26.0 & 25.0 & 17.0 & 4.0 & .3 & 29.7 & 4.0 & .7 & 11.4 & 8.9 & --- & .6 \\
\hline Average & 44.1 & 27.0 & 17.0 & 7.8 & 2.8 & .4 & 34.3 & 12.2 & 5.4 & 6.5 & 17.9 & .2 & 1.3 \\
\hline
\end{tabular}

Quartz includes monocrystalline quartz and polycrystalline quartz, chert, and quartzite. The monocrystalline grains are commonly strained, exhibiting various degrees of undulose extinction and, rarely, boehm lamellae. According to Dickinson (1970), the distinction between polycrystalline quartz and chert is arbitrarily made on the basis of size of the crystallites, with chert being less than $0.03 \mathrm{~mm}$, the thickness of a thin section. Every gradation in size between the two size categories can be seen in the thin sections studied. Also included in the chert designation by Dickinson (1970) is the chalcedonic variety, which is very rare in these samples. Although an attempt was made to separate these various forms of chert during the point count, all forms were later combined under the polycrystalline-quartz category. Polycrystalline quartz, as used here, therefore includes chert grains, recrystallized chert, and possibly some metamorphic quartzite, although this was included in the metamorphic-1ithics category when recognized.
Feldspar (2.6-27.0 percent) occurs primarily in the form of blocky, partially to totally altered grains. Plagioclase (1.3-11.3 percent), An 25-35 on albite twinning, is unzoned, normally albite twinned, and commonly altered to some extent by sericitization or kaolinization. Albite (1ess than 2 percent) is untwinned and fairly fresh, as is much of the potassium feldspar (1.0-6.7 percent). Grid twinning is exhibited by about 10 percent of the potassium feldspar, and grains of perthite and myrmekite are rare but found throughout.

Sedimentary lithic fragments compose a large percentage of each sample (18.3-58.6 percent) and include polycrystalline quartz (3.0-39.7 percent), calcite clasts (0-30 percent), and argillaceous-carbonaceous fragments (3.3-19 percent). The argillaceous and carbonaceous fragments are here treated together because of their close association in many grains and the difficulty of differentiation. often, though, the argillaceous fragments are finely layered and may contain silt-size or 


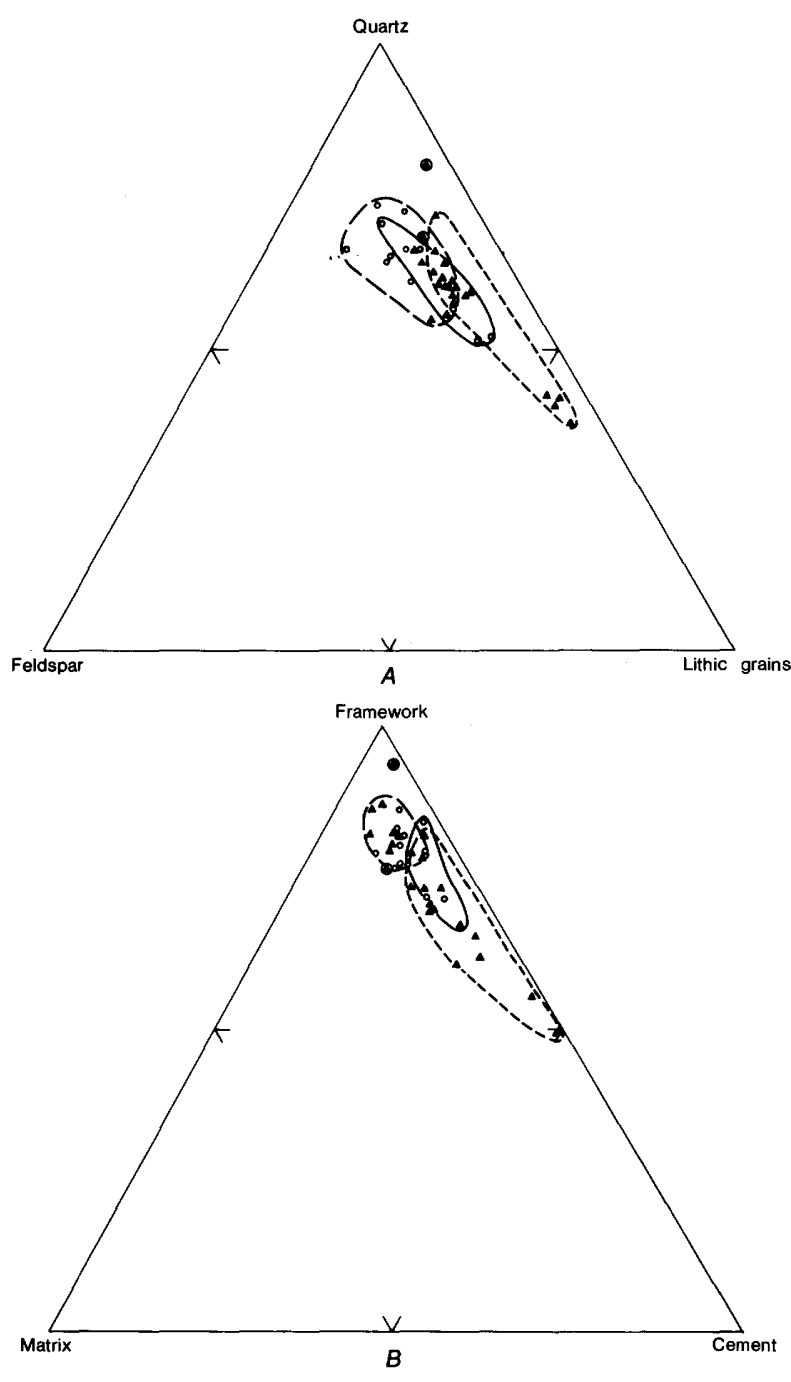

Figure 37.--Ternary diagrams of the data in table 5 showing (a) quartz (monocrystalline and polycrystalline quartz, quartzite, and chert), feldspar, and 1ithic grains; and (b) framework, matrix, and cement. $\bigcirc$, marine; $\Delta$, nonmarine; $($, samples not in measured section (77AAH183 and 77AAH184) but included in the petrographic study. Modified from Dickinson (1970).

- - - lowest segment from figure 41;

middle segment from figure 41;

- - - uppermost segment from figure 41 .

Figure 38.--Ternary diagrams using Folk's (1968) $\nabla$ divisions and end points, showing (a) quartz (monocrystalline quartz and quartzite), feldspar, and 1ithic fragments (including chert and polycrystalline quartz); (b) lithics; and (c) sedimentary lithics. $\bigcirc$, marine; $\Delta$, nonmarine; $\odot$, samples not in measured section (77AAH183

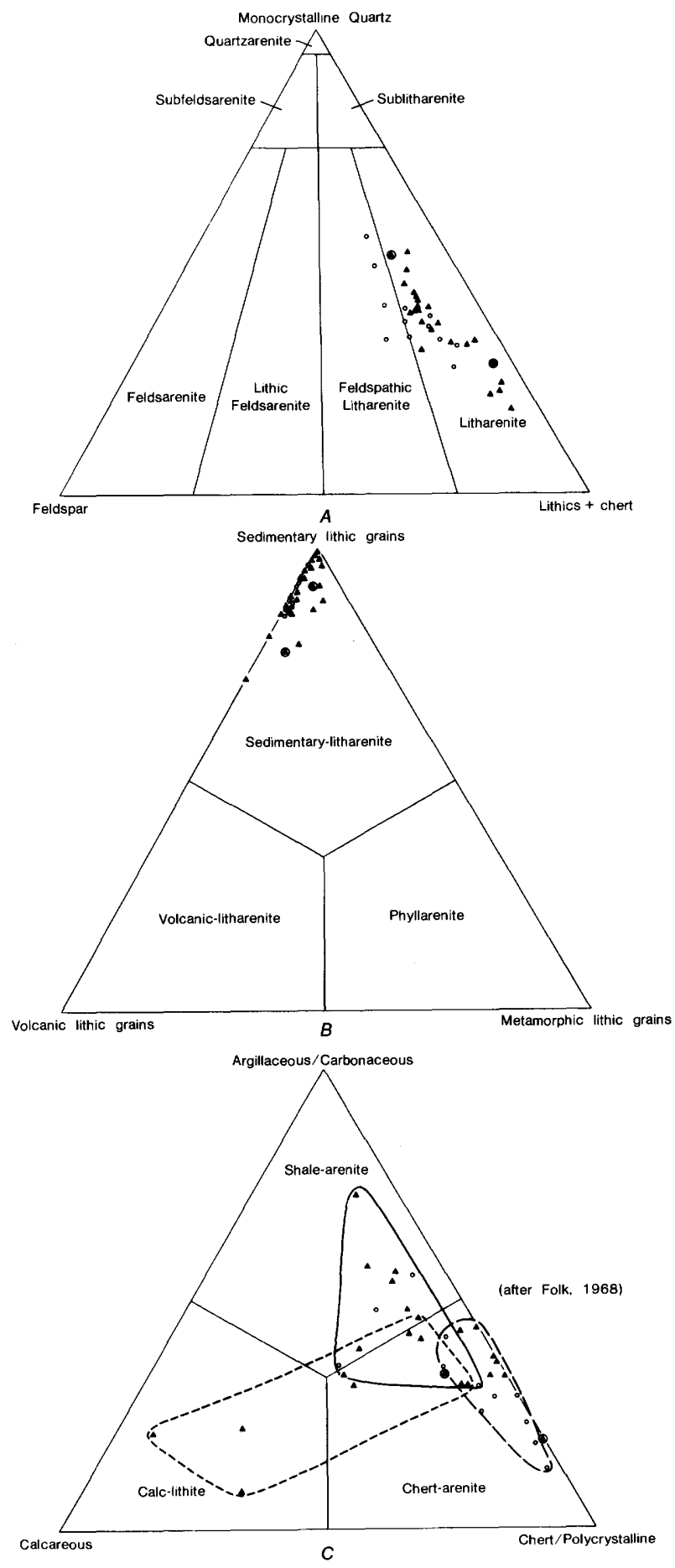


Table 6.--Textural data on samples from the south limb of Barabara Syncline

[Leaders (--) indicate not determined; $\mathrm{mD}$, millidarcy; $\mathrm{L}$, $M$, or $U$ following sample numbers indicates lower, middle, or upper sample from one sandstone unit; V., very; M., moderately; Mod., moderate; Sbrd, subround; Sbang, subangular; Ang, angular]

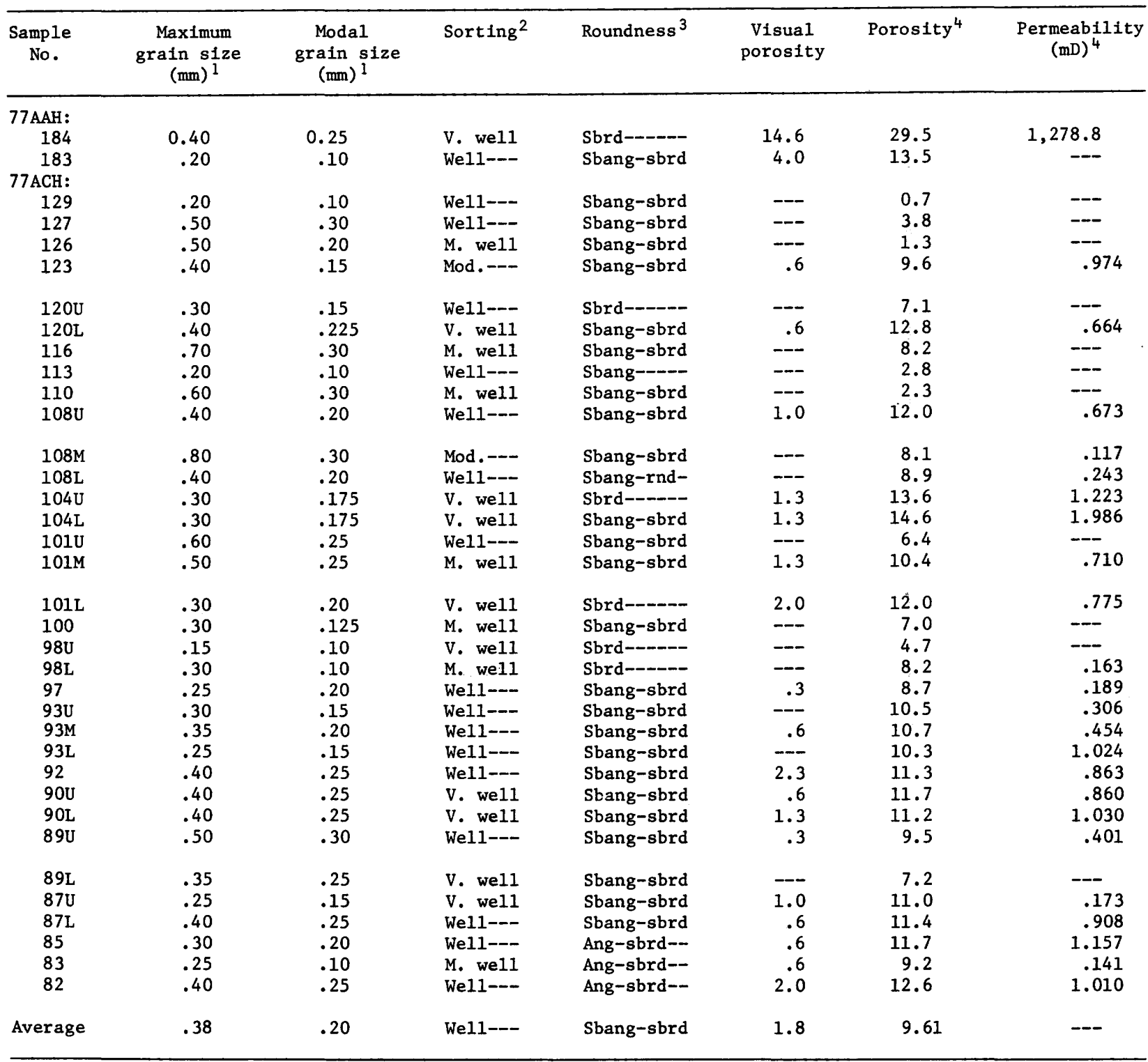

\footnotetext{
${ }^{1}$ Measured with petrographic microscope.

${ }^{2}$ Computed based on measured grain sizes.

${ }^{3}$ Estimated by comparison with Krumbein (1941) visual estimator.

${ }^{4}$ Measured by $I$. Pasternack.
}

smaller quartz grains, whereas the carbonaceous fragments and organic debris are massive and nearly opaque or deep orange along a very thin edge. Many of the sedimentary 1ithic fragments contain calcareous material, which may vary from very finely crystalline to blocky sparry calcite. A few of the samples show all stages of calcite recrystallization. Although some of this alteration may have taken place during diagenesis of rocks of the Nanushuk Group, much of it probably occurred in the source terrain. The resultant rounded clasts of recrystallized calcite surrounded by blebs or coatings of dark-brown to reddish-brown 1utum are characteristic of the western area (Bartsch-Winkler, this volume). Commonly these sedimentary lithic types are found associated with each other in various combinations in a single grain. 
Table 7.--Uranium and thorium of samples from the south limb of Barbara Syncline

[Values are in parts per million, as determined by delayed-neutroncounting technique. Values less than $3 \mathrm{ppm}$ Th were not reported, indicated by leaders (--). Analysts: H. T. Millard, Jr.; C. M. Ellis; and C. McFee. L, M, or U following sample numbers indicate lower, middle, or upper sample from one sandstone unit; n.d., not lower, middle,

\begin{tabular}{|c|c|c|c|c|c|}
\hline $\begin{array}{l}\text { Sample } \\
\text { No. }\end{array}$ & $\begin{array}{l}\text { Th } \\
\text { (ppm) }\end{array}$ & $\begin{array}{c}\mathrm{U} \\
(\mathrm{ppm})\end{array}$ & $\begin{array}{c}\text { Sample } \\
\text { No. }\end{array}$ & $\begin{array}{l}\text { Th } \\
(\mathrm{ppm})\end{array}$ & $\underset{(\mathrm{ppm})}{\mathrm{U}}$ \\
\hline 77AAH: & & & 77ACH: & & \\
\hline 184 & n.d. & n.d. & $101 \mathrm{~L}$ & 6.32 & 1.94 \\
\hline 183 & n.d. & n.d. & 100 & 9.79 & 2.22 \\
\hline 77ACH: & & & 980 & 16.14 & 3.17 \\
\hline 129 & 4.66 & 1.31 & $98 \mathrm{~L}$ & 15.33 & 2.91 \\
\hline 127 & n.d. & n.d. & 97 & 6.68 & 1.59 \\
\hline 126 & 8.15 & .97 & $93 \mathrm{U}$ & 11.65 & 1.50 \\
\hline 123 & 7.99 & 1.92 & $93 M$ & 6.31 & 1.34 \\
\hline $120 \mathrm{U}$ & 5.15 & 1.29 & $93 \mathrm{~L}$ & 8.80 & 2.11 \\
\hline $120 \mathrm{~L}$ & 4.21 & .92 & 92 & 5.16 & .74 \\
\hline 116 & 8.43 & 2.80 & $90 \mathrm{U}$ & 7.21 & 1.03 \\
\hline 113 & -- & 1.88 & $90 \mathrm{~L}$ & 9.12 & 1.29 \\
\hline 110 & 7.01 & 1.91 & $89 \mathrm{U}$ & 7.30 & .76 \\
\hline $108 \mathrm{U}$ & 8.62 & 1.59 & $89 \mathrm{~L}$ & 9.43 & .49 \\
\hline $108 \mathrm{M}$ & 6.16 & 1.45 & $87 \mathrm{U}$ & 5.96 & 1.05 \\
\hline $108 \mathrm{~L}$ & 5.45 & 2.08 & $87 L$ & 7.68 & .94 \\
\hline $104 U$ & 6.29 & 1.73 & 85 & 4.20 & .74 \\
\hline $104 \mathrm{~L}$ & 5.32 & 2.06 & 83 & 6.12 & 1.22 \\
\hline $101 \mathrm{U}$ & 5.71 & 2.17 & 82 & 3.41 & 1.13 \\
\hline $101 \mathrm{M}$ & 3.98 & 1.92 & Average & 7.30 & 1.58 \\
\hline
\end{tabular}

Volcanic lithic fragments (0-8 percent) are predominantly felsite (0-3.7 percent) but also include grains containing subhedral feldspar prisms and pyroxene crystals in a trachytic groundmass (0-2 percent). Hypidiomorphicgranular rock fragments are included in this category as well and, although not common, were present in many sections and constitute as much as 4 percent in one section.

Metamorphic lithic fragments (0-2.4 percent) are rare or absent in most of the samples and are almost exclusively quartzite grains in the lower portion of the measured section. These are strongly undulose, obviously stretched quartz grains containing several elongate domains that have serrated boundaries and occasionally containing muscovite or sericite flakes oriented with the elongation of the domains. In the upper portion of the section, quartzite increases in abundance and grains of foliated tectonites (0-0.7 percent) (phyllite and schist) and quartz-mica microgranulars (01.7 percent) (probably gneisses and granitic gneisses) also increase in abundance.

Most samples contain minor amounts of detrital muscovite, and a few contain small amounts of pleochroic straw-yellow to darkbrown biotite in flakes 0.1 to $0.3 \mathrm{~mm}$ long and nearly always bent or broken by compaction. Several flakes of what appeared to be detrital chlorite were also noted. Other heavy minerals present, in decreasing order of abundance, include hematite, magnetite, pyrite, zircon, apatite, and sphene.

The material classified as matrix in this study has been placed in the following two categories: (1) pseudomatrix (Dickinson, 1970), which includes material presumably derived from deformed clastic grains that have been squeezed into the intergranular spaces; and (2) other interstitial material, commonly composed of either fine detritus deposited in pore spaces or inhomogeneous materials grown during diagenesis but lacking the homogeneity or clear textural character necessary to be called cement. Pseudomatrix predominates in most of the samples studied, whereas the amount of other matrix material remains fairly constant at 1 to 2 percent and only very rarely exceeds 3 percent. Large intergranular spaces are commonly filled with unsorted and randomly oriented silt and clay particles composed of quartz, chlorite, sericite, and much unidentifiable material. It was suggested by Lambert (in Fox and others, 1979) that this type of material is detrital and probably represents "hash" resulting from the abrasion and disintegration of clastic grains. Many of the framework grains are surrounded by thin layers of dark-brown to reddish-brown material composed of subparallel flakes of chlorite and sericite as well as minute grains of unidentified clay.

Authigenic material including new growths, alteration products, and pore-filling cements are included as cement by Dickinson (1970). The most common and volumetrically most abundant cementing materials in the samples studied are calcite, silica, sericite, and kaolinite. Also present, but in much smaller amounts, are chlorite and small amounts of zeolites. By far the most abundant cement is calcite, which constitutes as much as 45 percent in one sample (77 ACH129) and averages almost 8 percent in thin sections studied throughout the section. In general it varies with the calcite-clast content and commonly can be seen growing out of these clasts. In the most extreme cases, the sparry calcite completely replaces all other constituents except for the quartz grains and deeply embays many of these. In such samples, ghosts of clastic grains can often be detected by relict outline of clay material. Also present in many samples are small rhombs of colorless carbonate which remain unaffected by the dye. These are thought to be composed of dolomite.

Silica cement is ubiquitous throughout the section. It occurs as overgrowths on quartz grains and as pore-filling material. Often the contact between the detrital grain and the new growth is marked by opaque inclusions. Sericite and kaolinite are present mainly as alteration of feldspars but also as pore-filling masses of intergrown crystals. No consistent sequence of diagenetic products was discernible in these samples although, in general, silica appears to have been formed earlier than calcite.

\section{DISCUSSION}

Comparison of the petrographic results with the stratigraphy yields somewhat ambiguous results. In general, the marine sandstones are finer grained and slightly better sorted than 
the nonmarine (figs, 39 and 40). The only generalities that are immediately obvious are that, in the upper part of the section, the cement content increases while the feldspar and volcanic rock fragments decrease (fig. 41). No consistent correlation between depositional environment, grain size, or composition is discernible.

Using the patterns that are recognizable in the plots of the composition data (fig. 40), certain tentative statements can be made concerning the provenance of the sediments in this portion of the Nanushuk Group. A pattern recognition study of the curves in figure 40 has resulted in the division of the section into three segments: from the base through Sample No. 77ACH97, from 77ACH98L through $77 \mathrm{ACH} 108 \mathrm{U}$, and from $77 \mathrm{ACH} 110$ to the top. Each of these segments can be characterized using the data in table 5. The bottom segment is high in chert and polycrystalline quartz, feldspar, and volcanic rock fragments and low in metamorphic rock fragments, calcite clasts, and cement. The middle segment is high in argillaceous-carbonaceous rock fragments and low in chert and polycrystalline quartz, vo1canic rock fragments, and metamorphic rock fragments. The uppermost segment is high in calcite clasts, calcite cement, and metamorphic rock fragments and low in monocrystalline quartz and feldspar. These groupings have been outlined on figures 37,38 , and 40 . Although there is much overlap of the groups, reflecting similarities of source terrain and mixing during transport and deposition, there are also significant differences and an obvious transition through time.

Primarily on the basis of the relative percentages of quartz, chert, polycrystalline quartz, feldspar, and the various lithic fragments, both Dickinson (1970) and Folk (1968) would classify the source of these sediments as a tectonically active sedimentary rock terrain. Folk (1968, p. 121) would further characterize the type of tectonism as horizontal deformation. The relative abundance of rounded feldspar and altered volcanic rock fragments low in the section indicates the presence of volcanic material in the source terrain. By far the most prominent characteristic of this part of the section is the abundance of chert and polycrystalline quartz. Higher in the section, the dominant 1ithology is shale mixed with chert and monocrystalline quartz. The upper portion of the section is dominated by carbonates with significant amounts of chert and polycrystalline quartz. The increase in content of metamorphic rock fragments indicates a contribution from a metamorphic terrain late in the deposition of these sediments.

This sequence of sediments strongly suggests that the primary sources of the Nanushuk Group in the middle and upper portions of the Corwin delta were the Shublik Formation of Middle and Late Triassic age, the Siksikpuk Formation of Early(?) Permian age, and the
Lisburne Group of Mississippian age. Figure 41 shows composite stratigraphic sequences from the DeLong Mountains and Lisburne Hills, as compiled by Martin (1970).

The overlapping of the groups outlined in figures 37,38 , and 40 may reflect the tectonic style in the source area as well as subsequent mixing of sediments during transport and deposition. Structure in the Brooks Range and Lisburne Hills is characterized by thrust faulting, which juxtaposed rocks of many different 1ithologies (Tailleur and Brosgé, 1970; Grantz and others, 1976). Exposure of a fault sliver of the Nuka Formation somewhere in the source area may help to explain the large feldspar and monocrystalline quartz content in the lower portions of the section. This formation was described by Tailleur and Sable (1963, p. 632) as a "succession of fine clastic, feldspathic coarse clastic, and cherty strata" and was tentatively correlated with the Siksikpuk Formation and the uppermost part of the Lisburne Group.

The major period of deformation in the western Brooks Range (DeLong Mountains) and Lisburne Hills took place in latest Jurassic and earliest Cretaceous time (Tailleur and Brosgé, 1970; Grantz and others, 1976; Grantz and Kirschner, 1976) and continued into Late Cretaceous and perhaps Tertiary time (Grantz and others, 1976). The stratigraphic and petrographic results of this study of the Lower Cretaceous (Albian) part of the Nanushuk Group strongly support such an interpretation.

\section{RESERVOIR POTENTIAL}

Data available at this time do not support strong conclusions concerning the potential of the Nanushuk Group of the western North Slope for containing either hydrocarbon or uranium and thorium reservoirs, but the results of this particular study are not encouraging for either. The low porosity and permeabilities (table 6); high matrix and cement content (table 5); general lack of continuous, stacked sand bodies; and overall paucity of sand in the whole western system are negative factors for both hydrocarbon and uranium potential. It should be noted, however, that Sample No. 77AAH184, collected from the trough of Barabara Syncline and thus the stratigraphically highest sample studied, had excellent porosity and permeability, and extremely low matrix and cement content. Even though this is only a 6-m-thick channel deposit that is about $50 \mathrm{~m}$ wide, it would make an excellent reservoir. Because it is the northernmost exposure of the Nanushuk Group, perhaps the subsurface extension to the north would be of interest for hydrocarbon potential.

The Nanushuk Group in the western North slope contains a large volume of plant debris and carbonaceous material; was deposited in nearshore-marine, estuarine, and nonmarine environments; and does not appear to have been swept by strongly oxidizing fluids. Bentonitic 

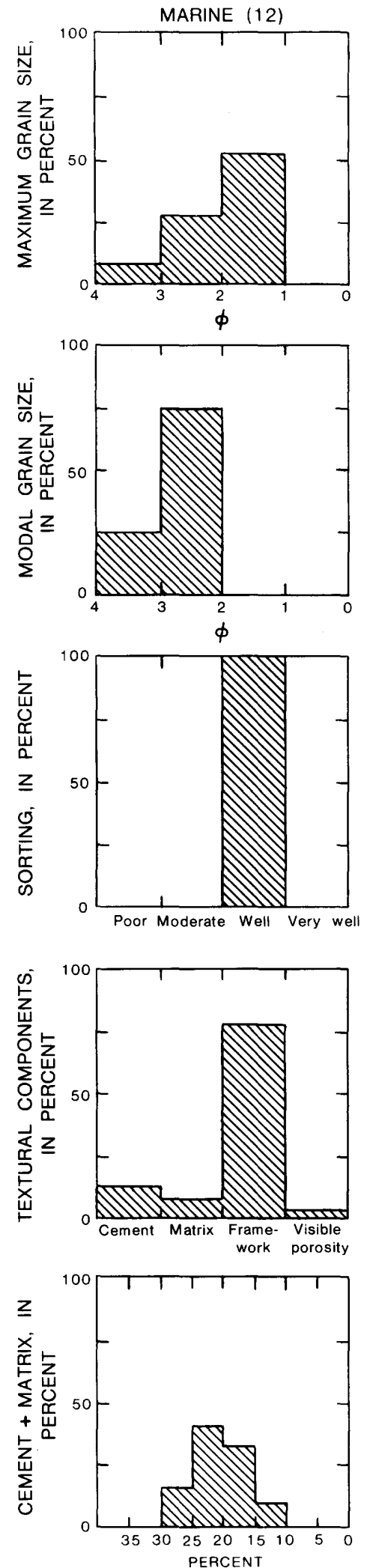
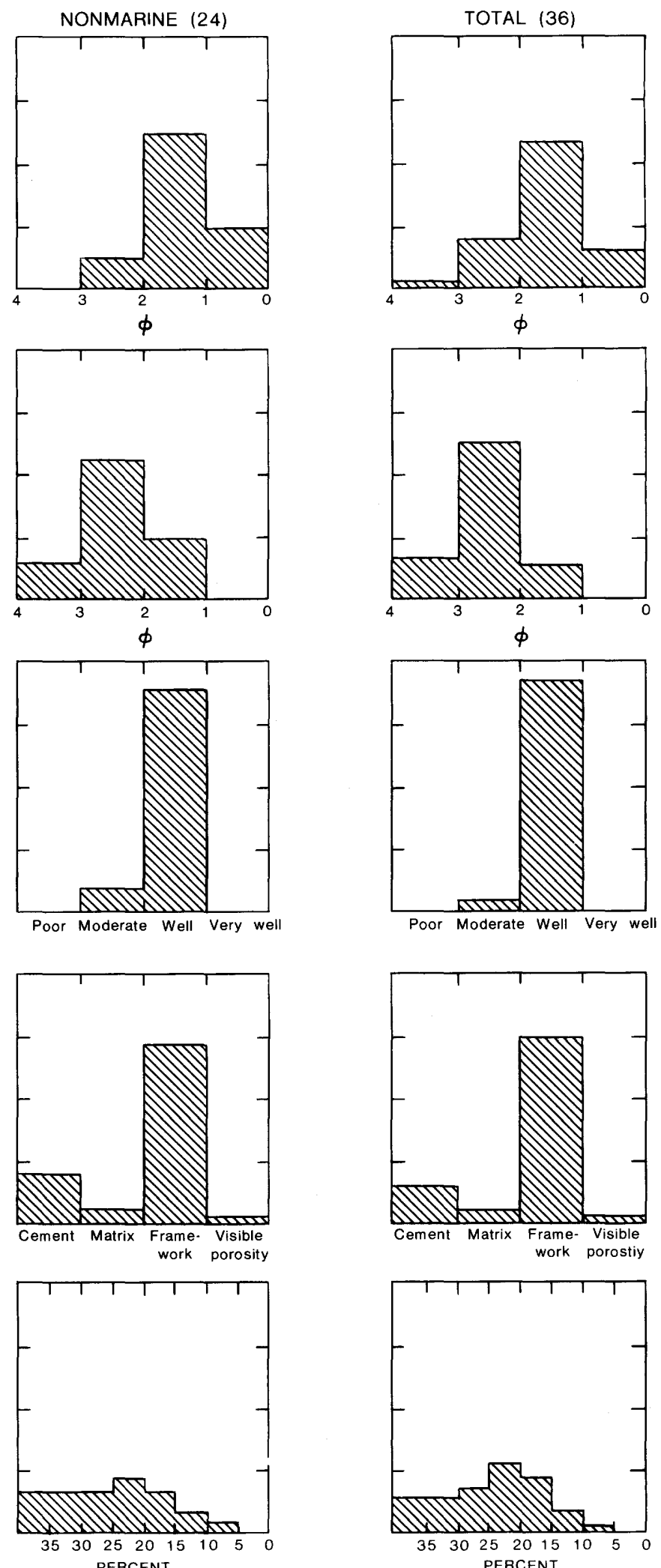

Figure 39.--Histograms of some parameters bearing on reservoir quality. Data from tables 5 and 6 . 


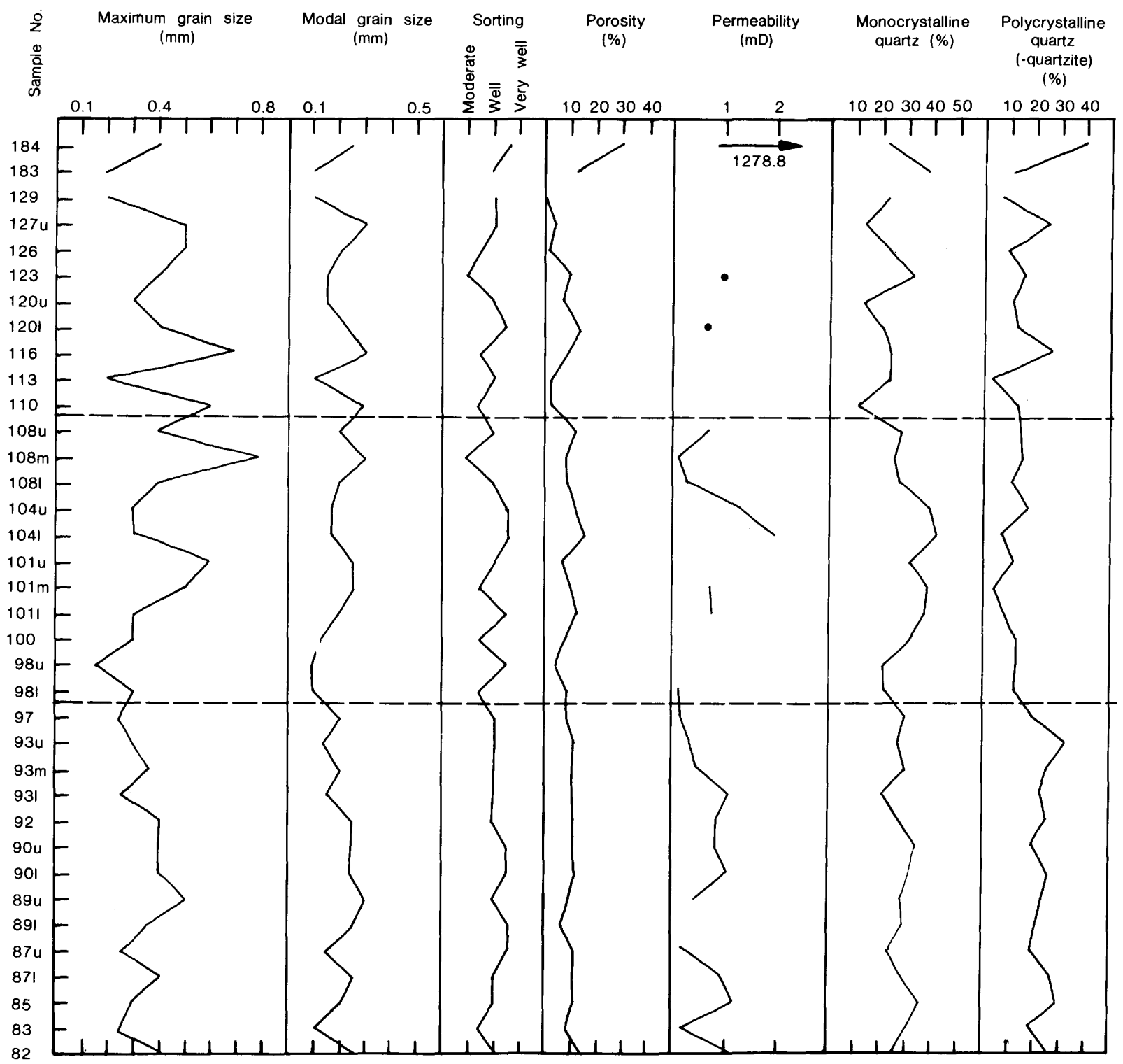

Figure 40.--Graphic representation of data from tables 5, 6, and 7. Segments shown on

clays occur high in the Nanushuk Group (Chapman and Sable, 1960), and the presence of as much as 21 percent combined feldspar and volcanic rock fragment content indicates volcanism or reworking of volcanic detritus in the source area. The same negative factors cited above, however, are also applicable to uranium potential. During the course of the field investigation, no evidence of possible uranium enrichment was seen. Delayed-neutron counts that were run on the samples from the Barabara Syncline measured section (table 7) yielded two samples, $77 \mathrm{ACH} 98 \mathrm{~L}$ and 77ACH98U, anomalous in both uranium and thorium. These low-level anomalies correspond to the highest concentration and greatest diversity of heavy minerals seen in the entire section and occur in an upper shoreface sandstone. Identified heavy minerals include muscovite, biotite, hematite, pyrite, apatite, sphene, and zircon. This concentration of heavy minerals could easily account for these very low level anomalies. 


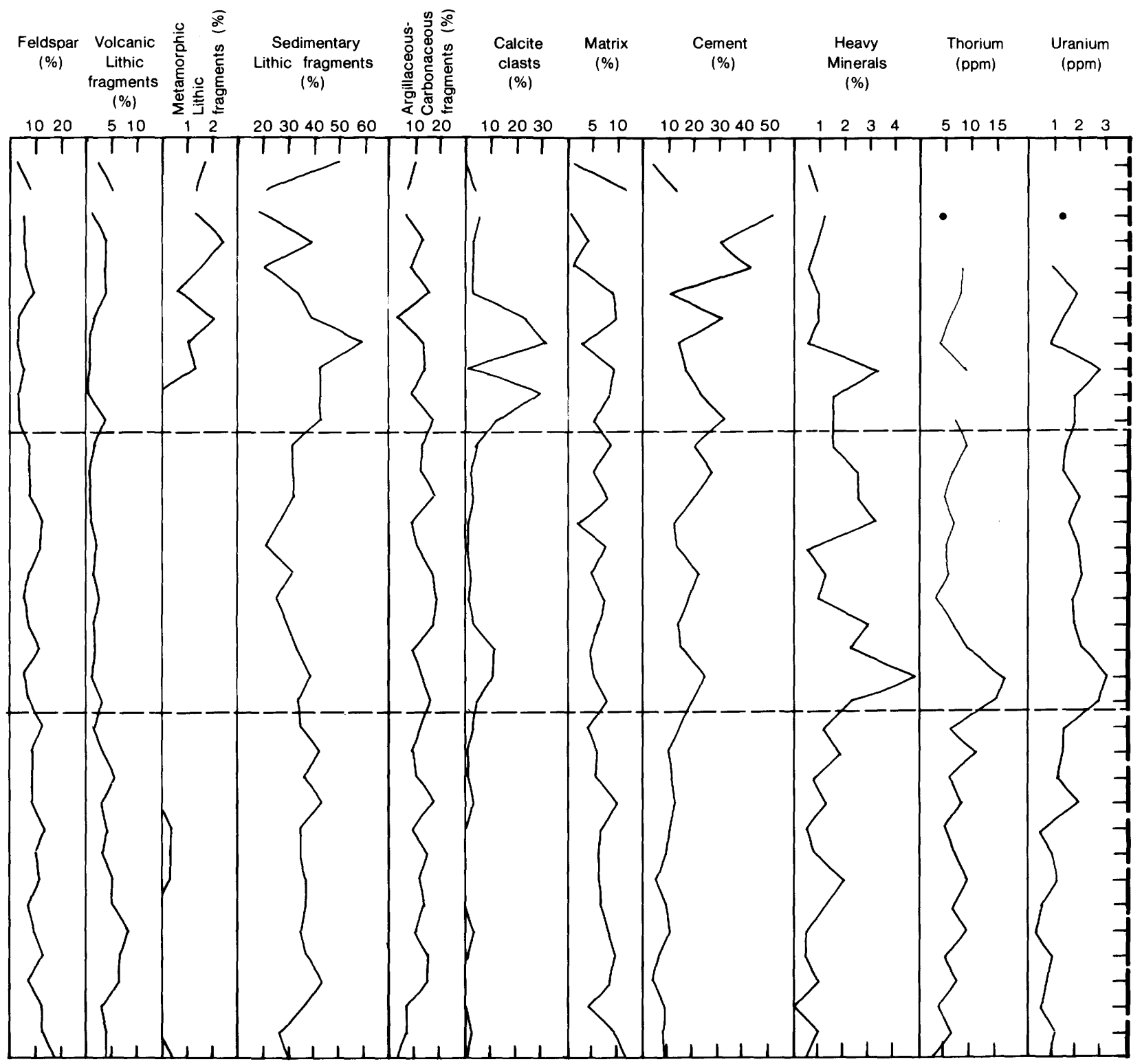

figures 37 and 38 separated by dashed lines and shown by symbols along far right margin. 


\section{Lisburne Hills}

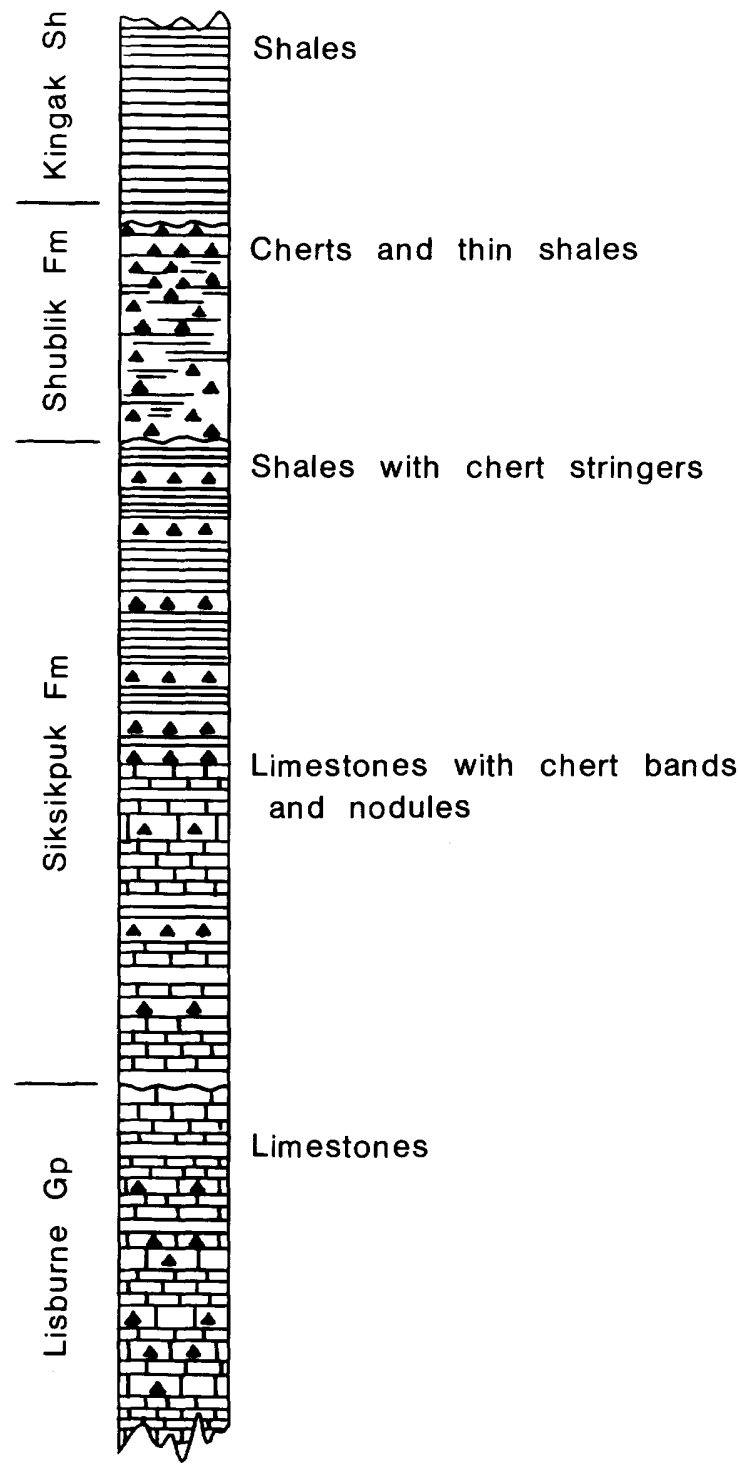

DeLong Mts.

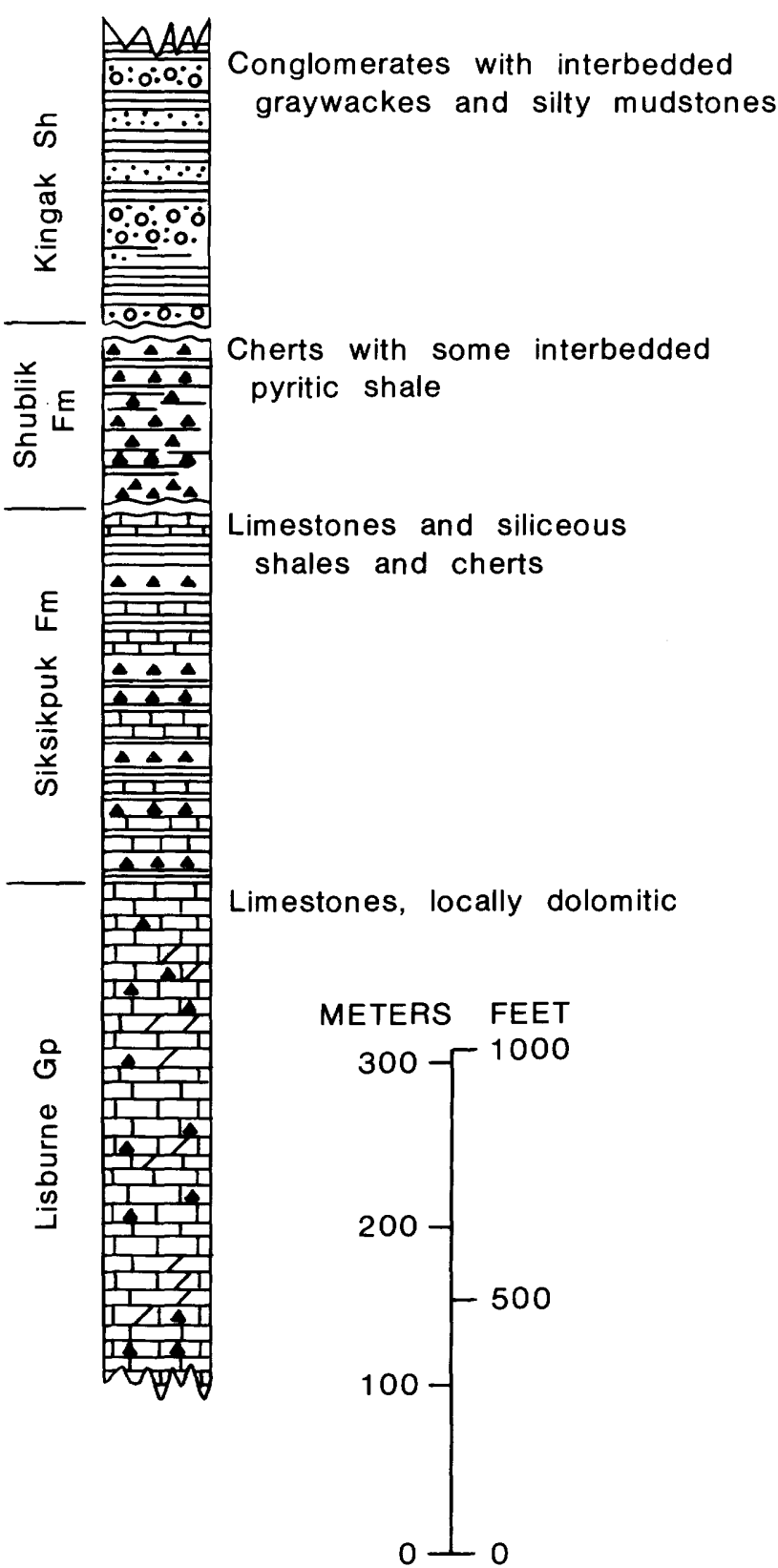

Figure 41.--Stratigraphic sequences of the Mississippian to lowermost Cretaceous section of the Lisburne Hills and DeLong Mountains; adapted from Martin (1970, fig. 2). 
SOME CRETACEOUS PLANT MEGAFOSSILS AND MICROFOSSILS FROM THE NANUSHUK GROUP, NORTHERN ALASKA: A PRELIMINARY REPORT

Richard A. Scott and Charles J. Smiley ${ }^{1}$

\section{INTRODUCTION}

Cretaceous sedimentary rocks crop out extensively in the Northern Foothills Belt of the Brooks Range, Alaska. Plant megafossils are common in many of the nonmarine and marginal-marine facies of these deposits (Smiley, 1966, 1969a, b, 1972a, b). In the western region of the North Slope, the Nanushuk Group includes the predominantly marine Kukpowruk Formation and the essentially nonmarine Corwin Formation. Both formations attain their maximum thicknesses to the west, where their type sections were described by Chapman and Sable (1960) from exposures along the Kukpowruk River and at Corwin Bluff, east of Cape Lisburne. Locations and lithologies of these and other exposures of the Nanushuk Group are given by Ahlbrandt and others (this volume). Collecting of the plant megafossils, sponsored by the Arctic Institute of North America and the U.S. Office of Naval Research, was conducted by Smiley during five field seasons in seven study areas across the region (fig. 42). The collection area extended from the Chandler River on the east to Corwin Bluff on the west, about $560 \mathrm{~km}$, and from the Northern Foothills Belt of the Brooks Range northward to the Arctic Ocean. About 10,000 identifiable specimens were collected from 250 plant-bearing beds, and at least 420 plant megafossil species are recognized at present.

Most of the rock units in northern Alaska had been described by geologists of the U.S. Geological Survey (Chapman and Sable, 1960; Detterman and others, 1963) before the plant megafossils were collected. On the basis of published descriptions of local sections, where available, Smiley was able to determine the precise stratigraphic level of plant-bearing beds at the time of collection. Fossiliferous marine rocks are interbedded in the areas of the Chandler, Colville, and Kukpowruk Rivers, permitting direct correlations between Smiley's floral zonations in nonmarine rocks and estab1ished faunal zonations in marine deposits (Smiley, 1972a).

${ }^{1}$ University of Idaho, Moscow, Idaho.

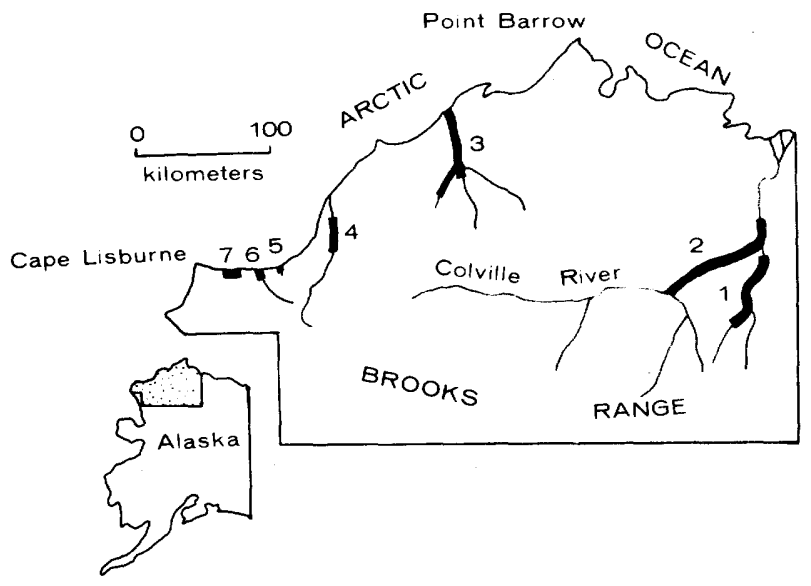

Figure 42.--Index map of northern Alaska study areas. 1, Chandler River; 2, Colville River; 3, Kuk River; 4, Kukpowruk River; 5, Punak Creek; 6, Pitmegea River; and 7, Corwin Bluff.

On the basis of these plant collections, a stratigraphic sequence of eight major floral zones was established through the Cretaceous rocks that are exposed across northern Alaska. Furthermore, 21 floral subzones were distinguished on the bases of stratigraphically restricted species and overlapping species ranges (Smiley, 1972a, b). Each floral zone can be recognized from a relatively small collection of plant megafossils, and many species appear to be good indexes of subzones. Forms may be distinguished by characters observable from small fragments (for example, fern fronds, conifer shoots). These megafossils often can be identified from drill-core samples as well as from larger specimens from the outcrop.

Palynological samples have been obtained from matrix material of the megafossil collections for most of Smiley's localities. Palynological samples were also made available through the courtesy of J. S. Lowther and the late $\mathrm{C}$. A. Arnold from the megafossil collections of Lowther (1957), along the Meade, Kuk, Avalik, Kaolak, and Colville Rivers. Additionally, 
some 400 palynological samples were obtained in the summer of 1977 as a part of the project that is the subject of this publication. Only a small proportion of these samples has as yet been processed; initial efforts were directed toward type and other exposures from the western edge of the North Slope.

The study by Smiley of the fossil leaves is well advanced, whereas palynological work, other than that done privately by commercial companies, is in its beginning stages. Nevertheless, good reasons exist for considering the plant megafossils and microfossils jointly. Leaves, spores, and pollen are not separate organisms; but they are separate parts of single organisms--plants--for which a detailed and workable biostratigraphic succession already is known for the Cretaceous of the North Slope. Also, in some areas of northern Alaska, recovery of palynomorphs is not adequate to establish an independent zonation.

Although the broad outlines of this megafossil-based biostratigraphy are available (Smiley, 1972a), taxonomic descriptions, illustrations, and ranges of individual taxa have not yet been published, limiting recognition of their usefulness in the field. It is the intent of this joint investigation to make these data available for individual taxa, to apply them to the correlation of beds of the Nanushuk Group and other Cretaceous deposits on the North Slope, and to utilize the pattern of floral succession shown by the megafossils as a framework for palynological information from both surface and underground rocks. As work progresses, data from plants will be integrated with those from dinoflagellates and other organisms in an effort to tie together events in the marine and nonmarine environments of deposition.

\section{FLORAL ZONES BASED ON MEGAFOSSILS}

The five floral zones of the Nanushuk Group (Zones IA, IB, II, III, and IV) range upward through an essentially continuous sequence of occasionally coal-bearing sedimentary rocks that totals a maximum thickness of about $5,500 \mathrm{~m}$; the sequence ranges in age from possible late Aptian into the Cenomanian. Fossil plants were collected from 192 localities in this portion of the Cretaceous section.

In the western region of the Alaskan North Slope, plant megafossils from the type section of the Corwin Formation represent Zones IA, IB, and II. The Corwin Formation elsewhere includes younger beds than are present at the type locality; such younger beds, containing plants from Zone III, crop out along the Kukpowruk River near the axis of Barabara Syncline at $162^{\circ} 43^{\prime} 39^{\prime \prime}$ W., 69 $29^{\prime} 55^{\prime \prime}$ N. Plants from the Kukpowruk Formation, including its type locality along the Kukpowruk River (Chapman and Sable, 1960), are assignable to Zones IA and IB. Zone
IV is not present in the Kukpowruk-Corwin region but is found eastward in beds of the upper part of the Nanushuk Group. The three major floral zones of the overlying Colville Group to the east span the time from Turonian (Zone V) through Santonian-Campanian (Zone VI) to early Maestrichtian (Zone VII). Stratigraphic relationships are discussed by Ahlbrandt and others (this volume).

The plant megafossil zones of the Nanushuk Group are distinguishable across the region and upward through local sedimentary sections. A selection of 30 megafossil species that are common, are readily identifiable, and represent the five major plant groups of the later Mesozoic (ferns, ginkgophytes, cycadophytes, conifers, and dicots) is included in this report. It should be emphasized that this is but a sampling of the many taxa that could serve equally well for regional correlations of nonmarine deposits. The list of plants and references to figured specimens on accompanying plates are as follows:

Ferns:

Arctopteris kolymensis Samylina (pl. 1, fig. 2)

A. rarinervis Samylina (p1. 1, fig. 1) Coniopteris inenarabilis (Hollick) (pl. 2, fig. 1)

C. onychioides Vass. and Kara-Mur. (p1. 2, fig. 2)

Ginkgophytes:

Ginkgo paradiantoides Samylina (p1. 3, fig. 1)

Ginkgo n. sp. (p1. 3, fig. 3)

?Ginkgoites (?Baiera) n. sp. (p1. 3, fig. 5) Phoenicopsis var 1 (pl. 3, fig. 4)

Phoenicopsis var 2 (pl. 3, fig. 2)

Phoenicopsis var 3 (p1. 3, fig. 7)

sphenobaiera pulchella (Heer) Florin (p1. 3, fig. 6)

Cycadophytes:

Nilssonia alaskana Hollick (p1. 4, fig. 2)

$N$ ilssonia cf. $N$. orientalis Heer (vars) (pl. 4, fig. 1)

Nilssonia cf. N. serotina Heer var 2 (p1. 4, fig. 5)

Nilssoniopteris polymorpha Sveshn. \& Bud.

(p1. 4, fig. 4)

?amites sp. (pl. 4, fig. 3)

Coniferophytes:

?Abieitites sp. (p1. 5, fig. 5)

Elatocladus n. sp. (pl. 5, fig. 4)

Juniperites n. sp. (pl. 5, fig. 2)

Pityophyllum var 1 (pl. 5, fig. 3)

Pityophyllum var 2 (p1. 5, fig. 1)

Podozamites var 2 (p1. 6, fig. 1)

Podozamites var 7 (p1. 6, figs. 3, 4)

Podozamites var 9 (p1. 6, fig. 5)

Podozamites var 15 (pl. 6, fig. 2) 
Dicotyledons:

cf. Ampelopsis multesima Hollick (p1. 7, fig. 1)

Cissites comparabilis Hollick (p1. 7, fig. 2)

?Cissites sp. (p1. 7, fig. 5)

cf. Platanus latiloba Seward (p1. 7, fig. 4)

Pseudoprotyphyllum cf. P. dentatum Hollick

(p1. 7, fig. 3)

of this selected 1ist of plant megafossil species, the following occur in the floral zones indicated below ( $*=$ confined to, or most characteristic of, the particular zone):

Floral Zone IA:

*Arctopteris kolymensis (entire zone, except top)

Arctopteris rarinervis (top of zone)

Coniopteris onychioides (entire zone)

Ginkgo paradiantoides (entire zone)

Gingko n. sp. (top of zone)

*Nilssonia cf. $N$. serotina var 2 (base to middle of zone)

*Phoenicopsis var 1 (base of zone)

* Phoenicopsis var 2 (middle of zone)

Phoenicopsis var 3 (top of zone)

Pityophyllum var 1 (rare in zone)

*Podozamites var 2 (top half of zone)

Floral Zone IB:

Arctopteris rarinervis (entire zone)

Coniopteris onychioides (entire zone)

Ginkgo paradiantoides (entire zone)

Ginkgo n. sp. (entire zone)

Phoenicopsis var 3 (entire zone)

* Pityophyllum var 1 (entire zone)

Podozamites var 2 (rare in lower half of zone)

Podozamites var 7 (rare in zone)

Podozamites var 9 (rare in zone)

Sphenobaiera cf. S. pulchella (entire zone)

*?Zamites sp. (entire zone)

Floral Zone II:

*?Abieitites sp. (entire zone)

Ginkgo paradiantoides (base of zone)

Ginkgo n. sp. (base of zone)

Nilssonia alaskana (entire zone)

Nilssonia cf. $N$. orientalis vars. (middle to top of zone)

* Nilssoniopteris polymorpha (entire zone)

Phoenicopsis var 3 (báse of zone)

Pityophyllum var 2 (entire zone)

* Podozamites var 7 (entire zone)

Podozamites var 9 (entire zone)

*Podozamites var 15 (entire zone)

Floral Zone III:

?Abieitites sp. (base of zone)

$*_{c f}$. Ampelopsis multesima (entire zone)
* Ciccites comparabilis (base of zone)

* Coniopteris inenarabilis (entire zone)

Elatocladus n. sp. (rare in zone)

*?Ginkgoites (?Baiera) n. sp. (base of zone)

* Juniperites n. sp. (entire zone)

Nilssonia alaskana (base of zone)

*Nilssonia cf. $N$. orientalis vars (entire zone)

Pityophyllum var 2 (base to middle of zone)

*cf. Platanus latiloba (base of zone)

Podozamites var 7 (base of zone)

Podozamites var 9 (entire zone)

Podozamites var 15 (rare, base of zone)

Floral Zone IV:

cf. Ampelopsis multesima (rare in zone)

*?Cissites sp. (entire zone)

*Elatocladus n. sp. (entire zone)

Podozamites var 9 (base of zone)

* Pseudoprotophyllum cf. P. dentatum (base of zone)

Figure 43, showing the stratigraphic ranges of the selected species from northern Alaska, is an example of the tabulation that has been done for all plant megafossil species collected. Figure 44 shows the stratigraphic occurrence and regional distribution of one entity, Nilssoniopteris polymorpha, illustrating the type of taxonomic-stratigraphic data that has been recorded for a11 Cretaceous plant taxa.

Many of the megafossil forms that seemed at first to be long-ranging species, such as Coniopteris onychioides (=?Cladophlebis alata Fontaine, in Ward, 1905; Knowlton, 1914), were found upon more detailed comparisons to represent a complex of several related species occurring in stratigraphic sequence. Whereas $C$. onychioides is represented by sterile and fertile fronds in Zones IA and IB, a closely similar fern that was referred originally to this species is now known to be morphologically distinct and to be confined to the overlying Zone II. These and other morphologicstratigraphic distinctions within apparently long-ranging forms currently are being clarified. (For example, four sequential species of the fern Arctopteris Samylina have been distinguished; Knowlton (1914) had referred them to a single species, Cladophlebis huttoni (Dunker) Fontaine.)

The material at hand shows that plant megafossils, when collected on a detailed stratigraphic basis, can serve as a valid and reliable means for correlations across a paleogeographic province such as the Cretaceous coastal plain of northern Alaska. When the total plant megafossil record from this region is analyzed, the major plant biostratigraphic zones of Smiley can be subdivided further into subzones for more precise correlations. 


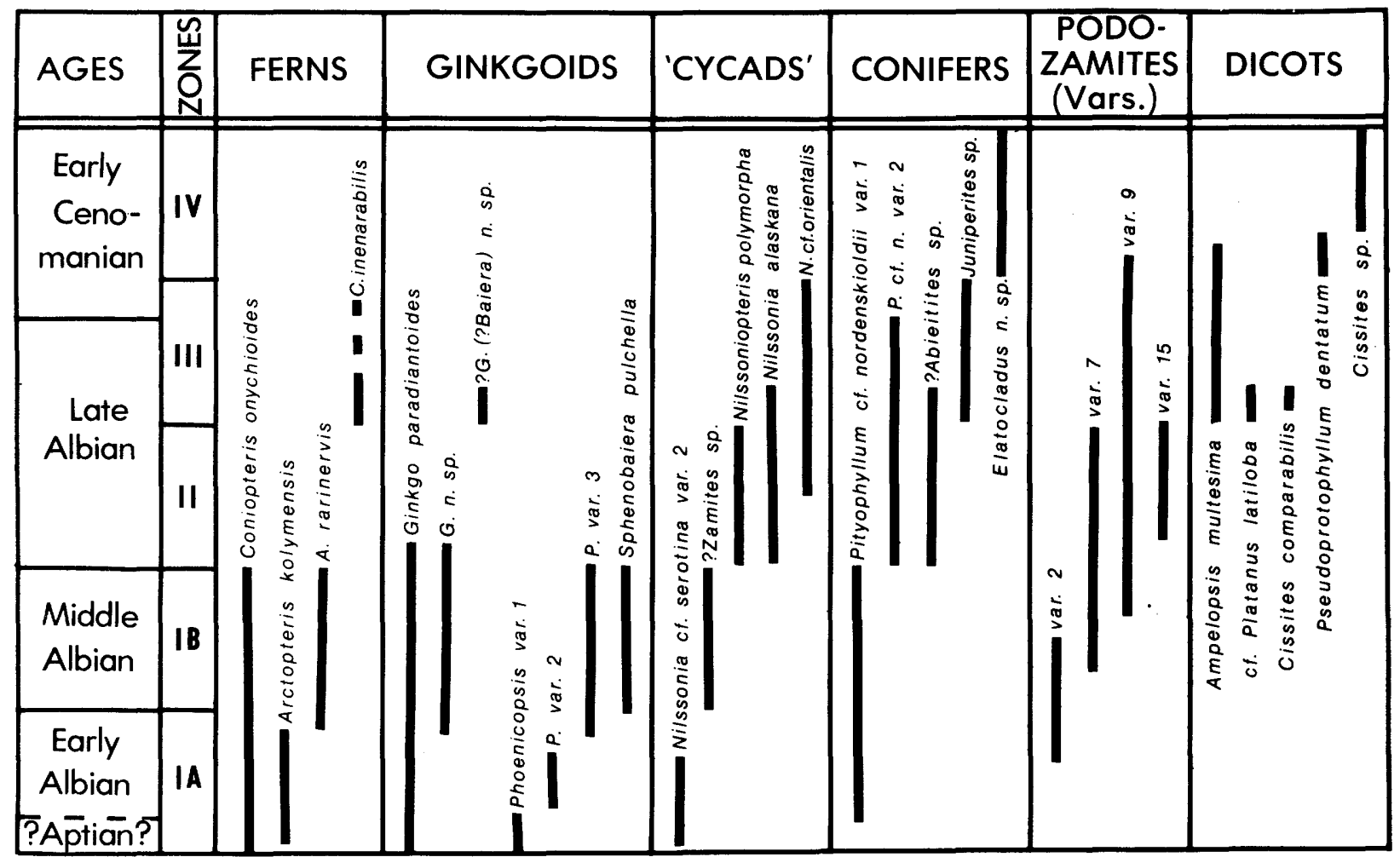

Figure 43.--Stratigraphic ranges of selected species of plant megafossils from northern Alaska.

\section{AGE DETERMINATIONS \\ FOR THE NANUSHUK GROUP}

The ages ascribed to the floral zones are based primarily on ammonite genera, species of Inoceramus, and foraminiferal assemblages from marine units that are interbedded with plantbearing deposits in some of the study areas (Jones and Gryc, 1960; Tappan, 1960, 1962; Imlay, 1961; Bergquist, 1966; S1iter, this volume). Marine faunal ages are reported to range from early Albian to early Cenomanian for the Nanushuk Group, and from Turonian to Santonian-Campanian for the overlying Colville Group. Sedimentary processes seem to have been interrupted during the late Cenomanian and Coniacian, and the floral and faunal records indicate breaks at these times.

Some of the plant species in the lower part of the Corwin Bluff section (fig. 42, study area 7) are typical of pre-Albian floras in the Siberian region to the west (Samylina, 1963, 1964). Other species with which they are associated are more characteristic of Albian floras in Siberia and northern Alaska. Such a coincidence of typically older and younger species in the same rock unit in northern Alaska suggests the possibility that plantbearing rocks of Aptian Age may be represented in the lowermost deposits in the western part of the Alaskan North Slope. Megaspores in the beds at Corwin Bluff indicate a probable Albian
Age, although pre-Albian strata in the lowest part of the Corwin Formation are not precluded. (See plant microfossil discussion.)

The entire Albian Stage seems to be represented in the sequence of floras and faunas of northern Alaska. These units have been correlated by floral and (in part) faunal zonations from the Chandler River area on the east to the Corwin Bluff area on the west (Smiley, 1969b, p. 2086-2088; 1972a, fig. 4). A probable early Cenomanian age for the upper part of the Nanushuk Group is indicated by the rich Inoceramus dunveganensis McLearn fauna (Imlay, 1961) in marine sands that are interbedded with plant-bearing deposits near the top of Floral Zone III and in Floral Zone IV. An episode of folding and truncation, apparently representing late Cenomanian time, took place prior to deposition of the Turonian Seabee Formation (Colville Group). The Seabee Formation is predominantly marine in the ChandlerColville region (one plant-bearing interbed occurs in the middle of the formation) and has plant-bearing nonmarine equivalents in the Kuk River area to the northwest (Smiley, 1966).

\section{CORRELATIONS OUTSIDE NORTHERN ALASKA}

Intercontinental high-latitude correlations of plant-bearing nonmarine rocks between eastern Siberia and northern Alaska were made recently by Samylina (1976). She found a close correla- 


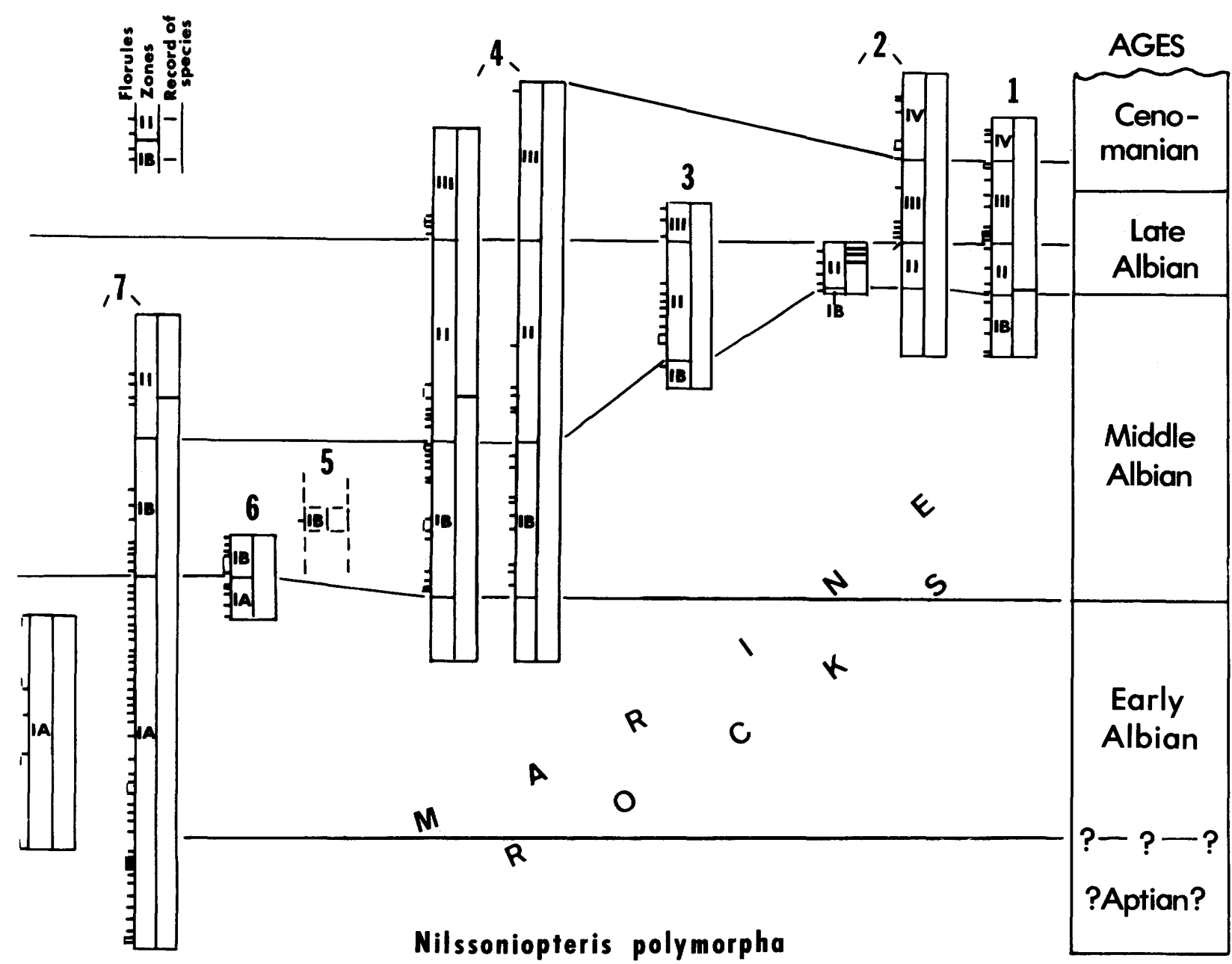

Figure 44.--Stratigraphic occurrence and regional distribution of Nilssoniopteris polymorpha in northern Alaska. Numbers 1-7 refer to the seven study areas shown in figure 42 .

tion between the sequence of floras in the Kolyma River area of northeastern Siberia and that in northern Alaska. Whereas the Siberian plant-bearing section of Aptian to Cenomanian Age rests on fossiliferous marine units, no marine interbeds are known to exist in the plant-bearing section itself. Samylina's comparison with the Alaskan record thus serves to correlate the Kolyma River floral records with a similar sequence in a contiguous region of the same floral province; in northern Alaska, interbedded, fossiliferous, marine units provide data for relating the various floral zones to the European scale for Cretaceous time. Comparisons with Hollick's (1930) Yukon River floras south of the Brooks Range orogenic belt show that most Yukon River species of ferns and gymnosperms occur also in deposits on the North Slope, where they are confined to units below those containing Floral Zone III. Most of the Yukon River dicot species similarly are represented in northern Alaskan floras, but they are not found in units below Zone III.
Because dicots are known to have progressed from lower to higher latitudes in middle Cretaceous time (Smiley, 1967), they probably first invaded the Yukon River region south of the Brooks Range highlands, becoming mixed with fern and gymnosperm species of Zone II age, before crossing the Brooks Range uplift and becoming established as dominant plants during the time of the Zone III floral change. The Yukon River species thus correlate with plants in Zones II and III of northern Alaska, and most likely are temporal equivalents of Floral Zone II (late Albian).

Plant megafossil correlations of nonmarine Cretaceous rocks west of the lower Mackenzie River were made by Smiley for the Canadian Geological Survey (in Young, 1975). Small collections of middle and later Cretaceous plant megafossils contain species that are stratigraphically restricted in the northern Alaskan sequence. The correlations made using these species conformed well with Young's conclusions based on other lines of evidence. 


\section{PLANT MICROFOSSIIS}

Little work has been published on pollen and spore assemblages from the Alaskan North Slope. Spores and pollen from strata along the Kuk and Kaolak Rivers were discussed by Langenheim, Smiley, and Gray (1960). Material from near Umiat representing the Tuluvak Tongue of the Prince Creek Formation (Colville Group), along with samples from the Corwin Formation at Kuk Inlet and Meade River, was studied by Stanley (1967). B. D. Tschudy (1969) reported on two genera of dicotyledonous pollen from Upper Cretaceous rocks along the Colville River. A sample from an unspecified locality in the Corwin Formation at Kuk Inlet was examined by Brenner (1976). Much more is known about the palynology of Cretaceous deposits in Canada; this work has been summarized for Arctic Canada by Brideaux and McIntyre (1975), and for the western Canadian Interior by Jarzen and Norris (1975) and Singh (1975).

Field collection of palynological samples for this study was begun in the western region of the North Slope. Initial sample preparation concentrated on the type sections of the Corwin and Kukpowruk Formations, on which these comments principally are based. It should be emphasized that this discussion is both general and preliminary owing to incomplete processing of samples and poor recovery, both in quantity and quality, of palynomorphs.

Plant microfossils observed in the type section of the Corwin Formation include such genera as Gleicheniidites, Cyathidites, Osmundacidites, Distyophyllidites, Sphagnum, Lycopodiumsporites, Verrucosisporites, Foveotriletes, Cicatricosisporites, and Cycadopites. A variety of bisaccate grains are also present, among them Vitreisporites, Pristinuspollenites, Alisporites, Pteruchipollenites, Piceaepollenites, Abietineaepollenites, Podocarpidites, and others in a complex of difficult-to-distinguish coniferous pollen.

The total assemblage represents a ferncycadophyte-conifer complex as demonstrated by the plant megafossils, except that the ginkgophyte component represented by leaves is not easily detected by pollen. In the section at Corwin Bluff, about 50 megafossils species of the oldest floral zone, IA, are predominantly foliage of ferns, cycadophytes, and ginkgophytes, and some generic change. Zone II contains about double the number of species, with a marked increase in the number and variety of conifers. The highest beds at Corwin Bluff are in Zone II; however, both Zones II and III are represented in the outcrops of the Corwin Formation along the Kukpowruk River. Zone III records the first occurrence of dicotyledonous plants, along with a sharp increase in number of species in all taxa.

Preliminary indications are that these plant zones can be distinguished palynologically in the Corwin Formation, although certain compositional differences are apparent for the plant microfossils. The most striking of these is the presence of abundant coniferous pollen. from Zones IA and IB, where megafossils of conifers are sparse. The limited variety of other palynological forms in Zone IA consists chiefly of fern spores, many of them gleicheniaceous. In Zone.IB, coniferous pollen is accompanied by an increased variety of other forms, including occasional examples of Klukisporites, Cicatricosisporites, Foveotriletes, Eucommilites, and Camarozonosporites. The increased number of megafossil species in Zone II is reflected by increased variety of palynomorphs, among them Rogalskaisporites, cf. Distaltriangulisporites, and Reticulisporites. Reworked Permian-Triassic pollen was observed in this zone, and probable Devonian spores were also seen in the Corwin Bluff section.

Spores and pollen from Zone III were recovered from beds at locality $77 \mathrm{AAH} 186$ ( $162^{\circ} 43^{\prime} 39^{\prime \prime}$ N., $69^{\circ} 29^{\prime} 55^{\prime \prime}$ W.), about $0.5 \mathrm{~m}$ south of the axis of Barabara Syncline along the Kukpowruk River. This is near Smiley's locality 59 (1969b, fig. 2D), where dicotyledonous leaves were found. This palynomorph assemblage contains at least three types of simple, tricolpate, dicotyledonous pollen. Numerous other forms are present, including occasional grains of Vitreisporites and Ephedra. Some palynomorph genera that are common in Lower Cretaceous deposits at lower latitudes, for example, in the Potomac Group of Maryland (Brenner, 1963), are rare or lacking in the type Corwin section. These genera include Trilobosporites, Concavissimisporites, Appendicisporites, and Classopollis. Cicatricosisporites, virtually absent in the lower half of the Corwin Bluff section, increases slightly in its upper half; it is more common, though not abundant, in younger, Zone-III beds of the Corwin Formation at Barabara Syncline along the Kukpowruk River (1ocality 77AAH186).

Many genera of spores and pollen present at the type section of the Corwin Formation are typical of cosmopolitan forms widespread in Albian time in the Northern Hemisphere. Including the younger Corwin beds exposed in the Snowbank Anticline-Barabara Syncline sequence along the Kukpowruk River, the Corwin palynomorph assemblage appears most like that found in the Canadian Christopher and overlying Hassel Formations, from above $75^{\circ} \mathrm{N}$. latitude in the Canadian Arctic Archipelago (Hopkins, 1974; Hopkins and Balkwill, 1973). The Christopher Formation, although marine, contains moderately abundant spores and pollen; tricolpate angiospermous pollen is present in the uppermost beds of the formation. The Christopher Formation is considered to be mid- to late Albian in age, with Albian ammonites present near the top of the formation (Hopkins, 1974). Tricolpate pollen grains are present throughout the overlying Hassel Formation, thought to be of latest Albian or early Cenomanian age (Hopkins and Balkwil1, 1973). 
Palynologically, strata at the type section of the Corwin Formation appear to be in part equivalent in age to the Christopher Formation, and the younger Zone-III Corwin beds along the Kukpowruk River may correspond in age to the Hassel Formation. This tentative correlation is based principally upon the level of occurrence of tricolpate pollen in these formations; some discrepancies of undetermined significance exist in the patterns of occurrence of such spore genera as Trilobosporites, Pilosisporites, Concavissimisporites, Cicatricosisporites, and Appendicisporites.

The Christopher and Hassel Formations serve at least to illustrate the difficulties of palynological zonation in the Early Cretaceous of the Arctic. Hopkins (1974) detected virtually no floral alteration throughout the Christopher beds; in the Hassel Formation the same palynomorphs were present throughout, with only minor differences in relative abundances (Hopkins and Balkwill, 1973).

Megaspores are present in the Corwin Formation both at Corwin Bluff and along the Kukpowruk River. These have been identified by R. H. Tschudy (written commun., 1978). Samples at Corwin Bluff from the oldest zone, IA, contained Arcellites reticulatus (Cookson and Dettmann) Potter, Minerisporites macroreticulatus Singh, and Minerisporites cf. M. marginatus (Kijkstra) Pot. Zone IB at Corwin Bluff includes Arcellites reticulatus, Minerisporites macroreticulatus, and Paxillitriletes cf. $P$. fairlightensis Batten. Megaspores also were obtained from a series of samples at irregular intervals, extending upsection from the top of the type section of the marine Kukpowruk Formation (Chapman and Sable, 1960) downstream to the north through the marine-nonmarine transitional beds into the nonmarine Corwin Formation. These localities are: 77AAH160 (162 ${ }^{\circ} 45^{\prime} 23^{\prime \prime}$ W., $\left.69^{\circ} 15^{\prime} 12^{\prime \prime} \mathrm{N}^{\prime}\right), 77 \mathrm{AAH} 165$ ( $162^{\circ} 45^{\prime} 40^{\prime \prime}$ W., $69^{\circ} 15^{\prime} 21^{\prime \prime N}$.) , $77 \mathrm{AAH} 172$ (162 $46^{\prime} 24^{\prime \prime}$ W., $69^{\circ} 15^{\prime} 24^{\prime \prime}$

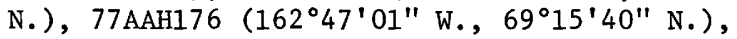
77AAH178 ( $162^{\circ} 47^{\prime} 15^{\prime \prime}$ W., $69^{\circ} 15^{\prime} 46^{\prime \prime}$ N.), $77 \mathrm{ACH} 74$ ( $162^{\circ} 39^{\prime} 19^{\prime \prime}$ W., $69^{\circ} 23^{\prime} 34^{\prime \prime} \mathrm{N}^{\circ}$ ), and $77 \mathrm{ACH} 79$

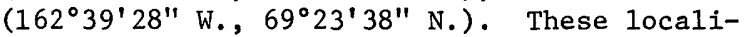
ties, not necessarily in stratigraphic sequence because of folding, are included in Zones IB and II. They contain, in aggregate, these megaspores: Arcellites reticulatus, Erlansonisporites reticulatus, Minerisporites macroreticulatus, $M$. cf. M. Borealis (Miner) Pot., $M$. cf. M. marginatus, $M$. sp., Paxitriletes cf. P. fairlightensis, and Triletes sp.

The two northernmost localities in this series, representing Zone III, are 77AAH183 $\left(162^{\circ} 46^{\prime} 15^{\prime \prime}\right.$ W., $69^{\circ} 20^{\prime} 57^{\prime \prime}$ N.) and 77AAH1 85

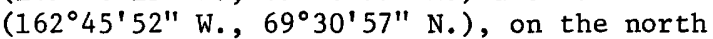
limb of Barabara Syncline and apparently at or near the stratigraphic level of the dicot leafbearing locality 77AAH186 ( $162^{\circ} 43^{\prime} 39^{\prime \prime} \mathrm{W}$., $\left.69^{\circ} 29^{\prime} 55^{\prime \prime} \mathrm{N}^{\prime}\right)$ on the south limb of Barabara Syncline. Localities 77AAH183 and 77AAH185 yielded these megaspores: Arcellites reticulatus, Paxillitriletes cf. P. dakotaensis
(Ha11) Hall and Nicolson, Erlansonisporites reticulatus, Minerisporites cf. $M$. marginatus, Triletes sp., and an undescribed new genus. R. H. Tschudy comments as follows:

"A11 of the above taxa have been reported from the Albian of western North America, and most of them appear to be limited to the AlbianAptian. However, very few pre-Aptian rocks have been examined for palynomorphs in this area, and even fewer have been searched for megaspores. Consequently, comparatively little is known of Neocomian megaspores.

"Perhaps the most diagnostic taxon is Arcellites reticulatus (Cookson and Dettmann) Potter. This fossil is known only from the Albian of Canada and Australia. A different species Arcellites disciformis (Miner) Ellis and Tschudy has a range extending from upper Barremian to Cenomanian. I re-examined all basal Cenomanian megaspore slides available in the Denver laboratory to attempt to find out if the range Arcellites reticulatus extended into the basal Cenomanian (Dakota) of Colorado, Utah, and New Mexico. Arcellites disciformis was the only species of Arcellites found.

"The two stratigraphically highest samples, 77AAH183 and 77AAH185, differed somewhat from the other samples in their greater diversity of megaspores. Both samples, however, yielded specimens of Arcellites reticulatus. It is my opinion that all the samples examined pertain to the Albian. Because of the incompletely known ranges of many of these megaspores, future work may extend the ranges of some into the Cenomanian. However, in light of present knowledge none of the samples can possibly be younger than earliest Cenomanian."

In addition to material from the Corwin Formation, palynological preparations have been made from the type Kukpowruk Formation, and from sections at Coke Basin, Dugout Syncline, Seaview Syncline, and Archimedes Anticline. Although palynomorphs are present in many of these samples, the quality of preservation generally is not good. One of the perplexing aspects of attempting to utilize palynology with Cretaceous rocks of the western North Slope is the poor recovery and poor preservation of palynomorphs from even such apparently favorable lithologic sequences as the type exposure of the Corwin Formation. Here, in some 3,000 m of nonmarine beds, sandstones and siltstones alternate with organic shales and coals, lithologies that elsewhere commonly contain many palynomorphs. In this Corwin section, they typically are sparse or lacking in pollen and spore content. Many relatively fine grained, Cretaceous leaf-bearing beds elsewhere typically contain spores and pollen in the matrix materia1; in the Corwin Formation the siltstones in which most leaves are found typically are barren, or nearly so, of palynomorphs.

Several factors are possibly responsible for the poor representation of palynomorphs in 
the type Corwin Formation and elsewhere on the western North Slope. The lack of pollen and spores in the leaf-bearing siltstones probably is related to the higher energy levels in this depositional environment. Recent studies by Retallack (1977) and by Hickey and Doyle (1977) have begun to relate the affinities and nature of plant remains to their locale of growth and preservation in the sedimentary environment. By the conclusion of this study, we anticipate that it will be possible to adduce such relationships to some degree in connection with the work by Ahlbrandt and others (this volume) on depositional environments represented by rocks of the Nanushuk Group. But lack of suitable depositional environments does not appear to be a primary cause for the scarcity of palynomorphs. In many cases, biological or chemical degradation of the sporopollenin in the palynomorph wall is evident; further study of deterioration in the Nanushuk palynomorphs is planned. Many samples unavoidably were taken from oxidized zones near the surface, which may account for poor recovery. The degree of maturation of the organic material in these rocks is higher than was anticipated (Magoon and Claypool, this volume) and probably is in part responsible for the poor preservation seen in many samples. One possible key to an original lack of palynomorphs may be furnished by the record of the plant megafossils. The oldest floral zone, IA, contains about 50 species, mostly ferns, ginkgophytes, and cycadophytes. Zone IB includes about 55 species from the same taxonomic groups, plus some conifers. Diversity increases in Zone II, with some 102 species, including the first rare dicotyledonous leaves. Zone III, with 176 species, is characterized by a striking increase in the number of species in most higher taxa; dicots are first significant in this zone (Smiley, 1972b). The beds at the Corwin type section are included in Zones IA, IB, and II, with floral diversity ranging from 50 to about 100 species in aggregate.

It is significant that these species counts reflect the total flora of the zones. A plant megafossil collection from any given level in the rocks typically contains only about five or six commonly occurring species. These forms are the ones apparently indigenous to and best able to reestablish themselves in the constantly altering environments of rapid deposition reflected in many of the thick Corwin beds. Changes in these small associations through time provide the basis for the zonation shown in figure 43. The presence of megaspores, not usually amenable to longdistance transport, documents the record of local vegetation in the Corwin sediments. Although some spores and coniferous pollen were certainly carried in, the limited variety and numbers of palynomorphs reflect in part the output of small, local plant associations diluted by rapid rates of sedimentation during early Corwin time. Interestingly, the oldest sample yet found that yielded well-preserved palynomorphs in quantity was from Zone-III beds of the Corwin Formation on the Kukpowruk River (locality $77 \mathrm{AAH} 1862,162^{\circ} 43^{\prime} 29^{\prime \prime} \mathrm{W}$., $79^{\circ} 29^{\prime} 55^{\prime \prime}$ N.). Megafossil collections document that increase in numbers of species had taken place in Zone III, increasing the supply of palynomorphs to the sediments.

The apparent low number of plant species at the type section of the Corwin could be related to the location of such floras at high latitude (Smiley, 1967; Brenner, 1976; Hickey and Doyle, 1977). However, the Christopher flora, located at even higher latitude, is as rich in numbers of species as many Early Cretaceous assemblages from far to the south (Hopkins, 1974); and the total number of species for Zone $I$ in the Corwin Formation is comparable. On the Alaskan North Slope, the increase in numbers of species upward through Smiley's zones suggests that palynological efforts will become more rewarding as work on the Nanushuk Group progresses eastward into younger rocks on the North Slope.

The potentially best palynological datum that exists within the Nanushuk Group is the first appearance of tricolpate angiospermous pollen. In low latitudes, this morphological pollen type enters the geological record in the Aptian (Hickey and Doyle, 1977); in western Canada, tricolpate pollen is first found in sediments of middle or late Albian age (Singh, 1975; Jarzen and Norris, 1975). Brenner (1976) reported that, in the the Canadian Arctic and northern Alaska, tricolpate pollen does not appear until the Cenomanian. Tricolpate pollen grains are present in uppermost beds of the Christopher Formation, of latest Albian age (Hopkins, 1974), and tricolpate grains in the Corwin are probably latest Albian or early Cenomanian. This apparent poleward progression in time is thought to mark the migration of early angiosperms from low latitudes. On the North Slope, the presence of pollen of the first angiospermous plants apparently serves to mark the approximate position of the AlbianCenomanian boundary.

Once present, the angiosperms diversified rapidly, evolving a series of pollen types with increasingly complex morphology. This sequence is significant stratigraphically; it has been worked out for Cretaceous deposits in western Canada (Jarzen and Norris, 1975; Norris and others, 1975; Singh, 1975). A variety of dicotyledonous pollen is known to occur in post-Albian rocks on the North Slope and should be useful in their zonation.

\section{PALEOECOLOGY}

Uniformity of floral changes across the North Slope, shown by plant megafossils from the Nanushuk Group, are consistent with regional climatic changes (Smiley, 1972b). Some climatic inferences have been derived from changes in 
the proportionate representation of major plant groups. In Zones IA, IB, and II, such indicators of warm climatic conditions as the cycadophytes were relatively abundant; in Zone III they declined to extinction. Conversely, conifers, generally indicators of cooler conditions, are poorly represented in Zone IA, increase gradually upward, and become codominants in Zone III. Both changes are consistent with a warm period followed by cooling. Morphological characteristics of ginkgophyte (size attributes) and angiospermous leaves (margin features) are also consistent with a warm, frost-free environment in the Albian, followed by cooler, warm-temperate conditions from latest Albian to Turonian time. Contrary to their megafossil record, conifers are well represented by pollen at the Corwin type section. It may be inferred that coniferous forests existed on the adjacent highlands, from which the Corwin sediments were carried to the shoreline environments of deposition. R. H. Tschudy (written commun., 1978) has pointed out that the plants which produced the megaspore Arcellites, present in the Corwin Formation, were undoubtedly water ferns growing in freshwater lakes or ponds. Furthermore, because of their comparatively large size, megaspores generally are not deposited at great distances from their points of origin.

\section{SUMMARY}

Plant megafossil records and biostratigraphic zones based upon them have been shown to be useful in correlating nonmarine rocks of Cretaceous age across northern Alaska. Such correlations also have been demonstrated between northern Alaska and adjacent regions to the east (northwestern Canada), to the south (central Alaska), and to the west (northeastern Eurasia). A unified floral province during Cretaceous time seems to have extended at least from the Mackenzie River area on the east to west of the Lena River on the west (Vasilevskaya and Pavlov, 1963). The province extended from the Arctic Ocean to probably the Pacific Ocean in Alaska, and from the Arctic Ocean to south of the Okhotsk Sea in northeastern Eurasia (Lebedev, 1974). Most of the plant megafossil species that compose the Cretaceous floras within this floral province appear to be restricted to this part of the world, at least during middle Cretaceous time. Plant megafossil correlations of nonmarine rocks within this province are practical and reliable. Correlations with other floral provinces, or with floras of significantly different latitudes, appear not to be applicable at the species level (Smiley, 1967), but the floras may be correlative at the generic level.

Despite problems with inadequate recovery of palynomorphs from Lower Cretaceous beds in the western region of the Alaskan North Slope, preliminary information has been obtained. The major floral zones of Smiley appear to be recognizable from spores and pollen. Megaspores from the type section of the Corwin Formation corroborate its Albian Age. The recovery of simple, tricolpate, dicotyledonous pollen near or somewhat above the Albian-Cenomanian boundary in the Corwin Formation establishes a palynological datum that should be recognizable eastward along the North slope. 
PLATES 1-7. All illustrations are about 90 percent of natural size.

PLATE 1

Figure 1. Arctopteris rarinervis Samylina.

2. A. kolymensis Samylina. 


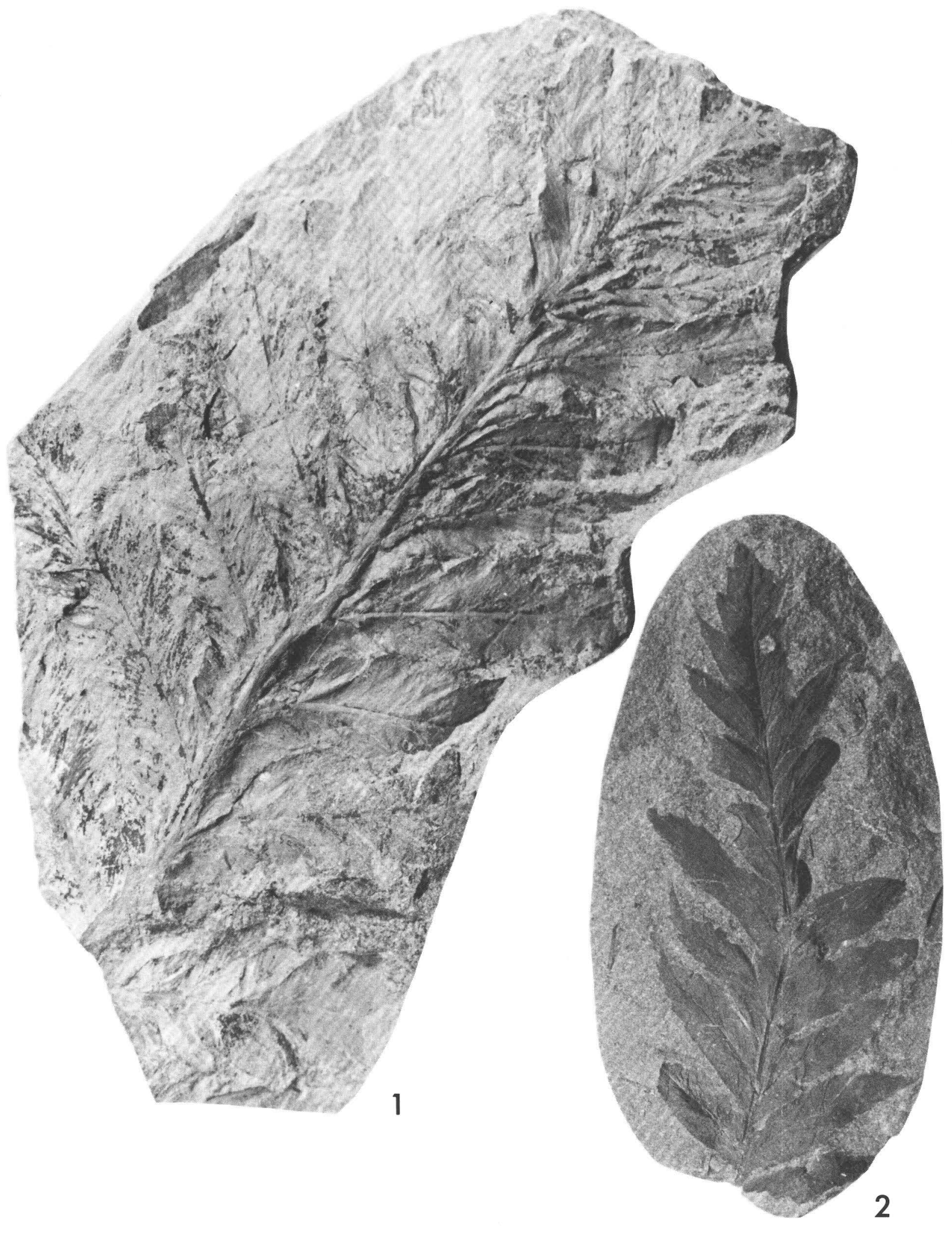


PLATE 2

Figure 1. Coniopteris inenarabilis (Hollick).

2. C. onychioides Vass. and Kara-Mur. 


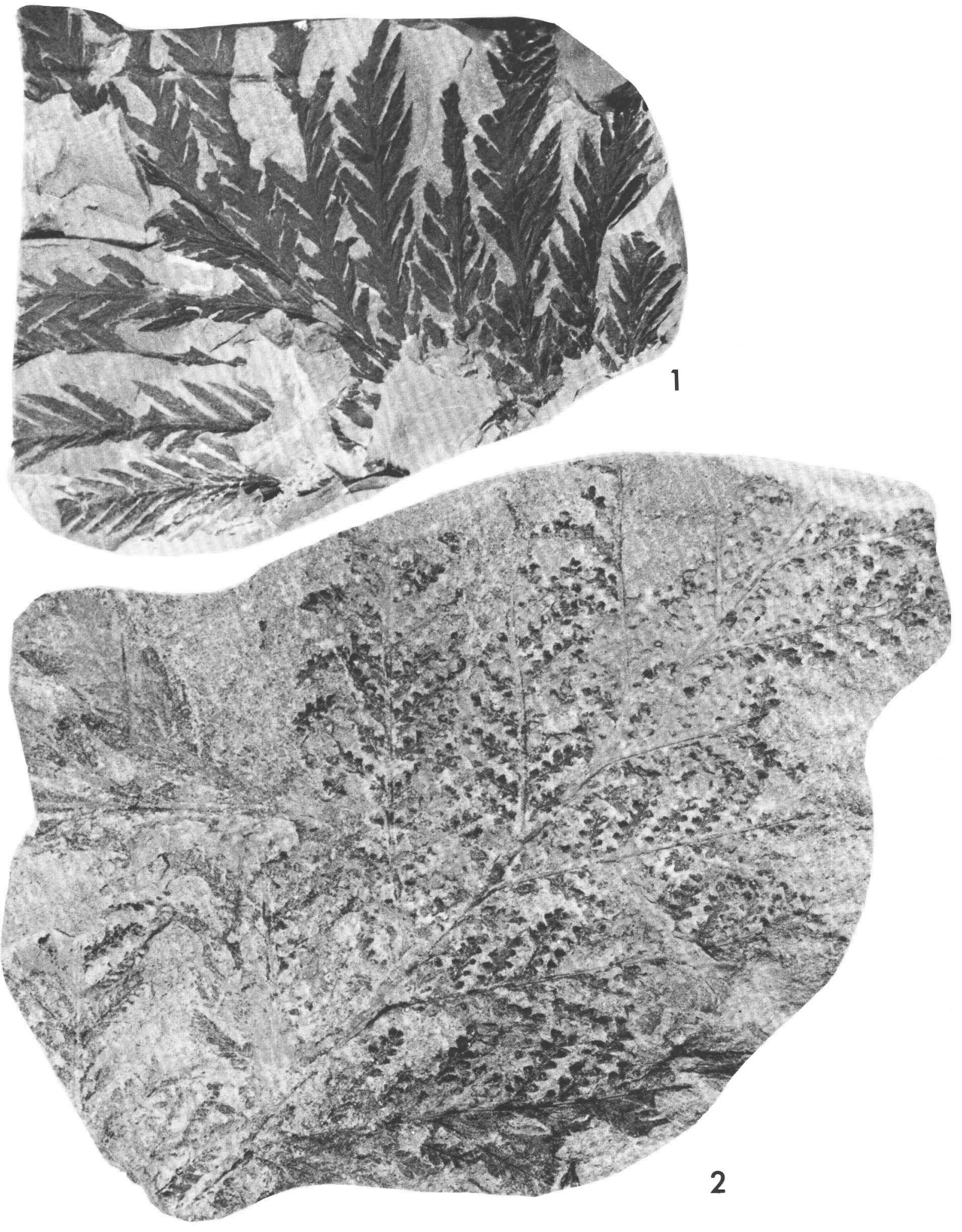


PLATE 3

Figure 1. Ginkgo paradiantoides Samylina.

2. Phoenicopsis var 2 .

3. Ginkgo n. sp.

4. Phoenicopsis var 1 .

5. ?Ginkgoites (?Baiera) n. sp.

6. Sphenobaiera pulchella (Heer) Florin.

7. Phoenicopsis var 3 . 


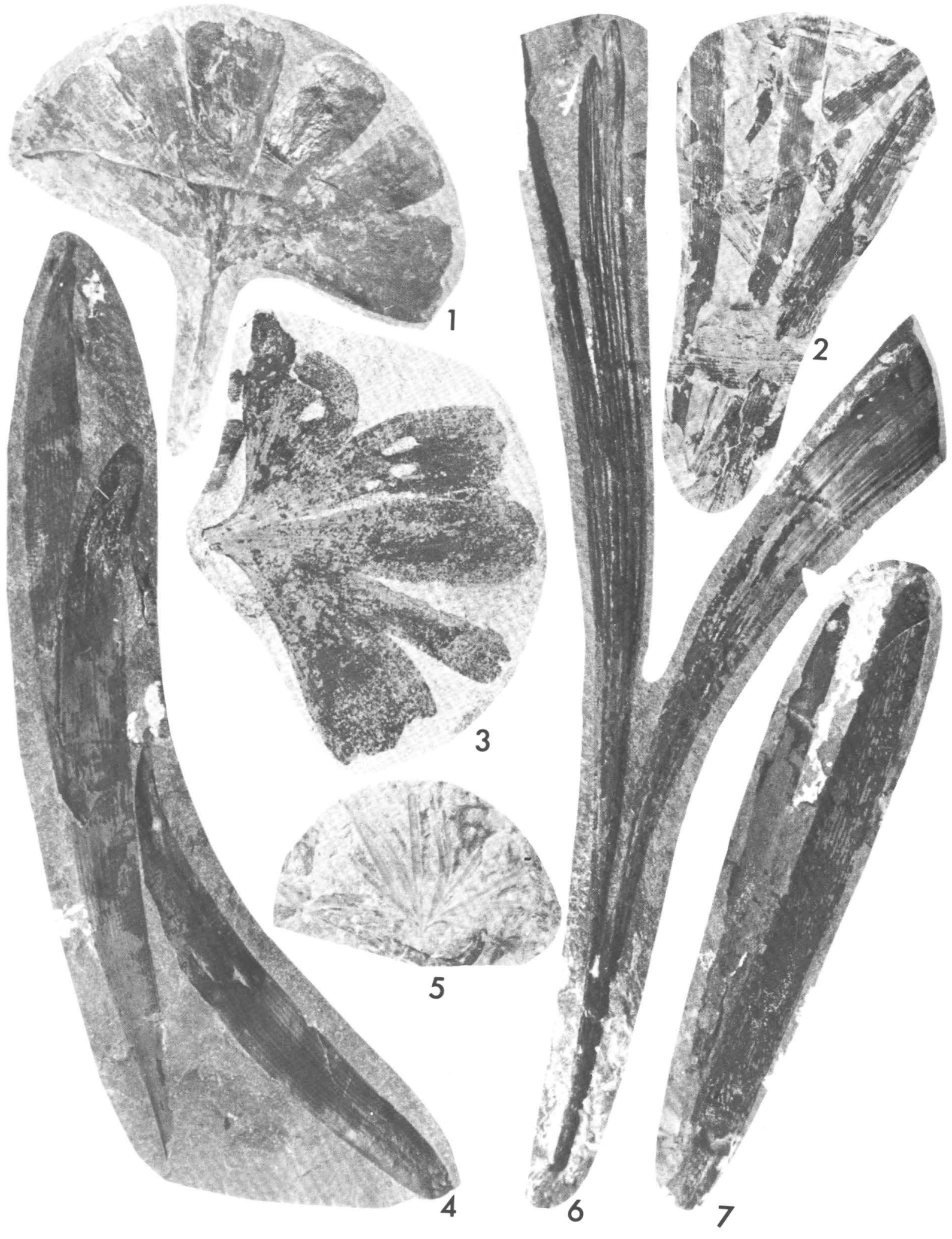


PLATE 4

Figure 1. Nilssonia cf. N. orientalis Heer.

2. N. Alaskana Hollick.

3. ?Zamites sp.

4. Nilssoniopteris polymorpha Sveshn. \& Bud.

5. Nilssonia cf. N. serotina Heer var 2. 


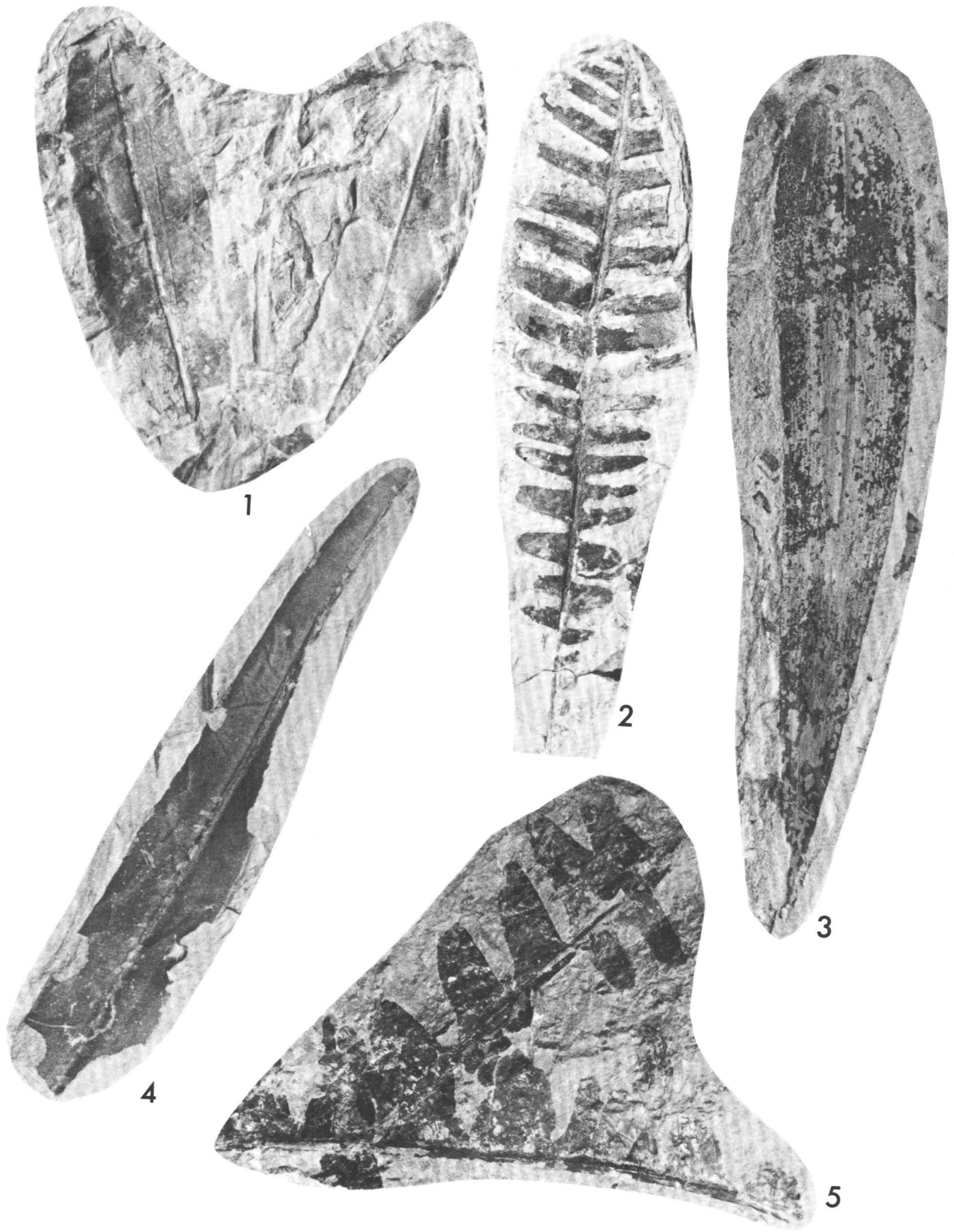


PLATE 5

Figure 1. Pityophyllum var 2.

2. Juniperites n. sp.

3. Pityophyllum var 1 and Podozamites sp.

4. Elatocladus n. sp.

5. ?Albieitites sp. 


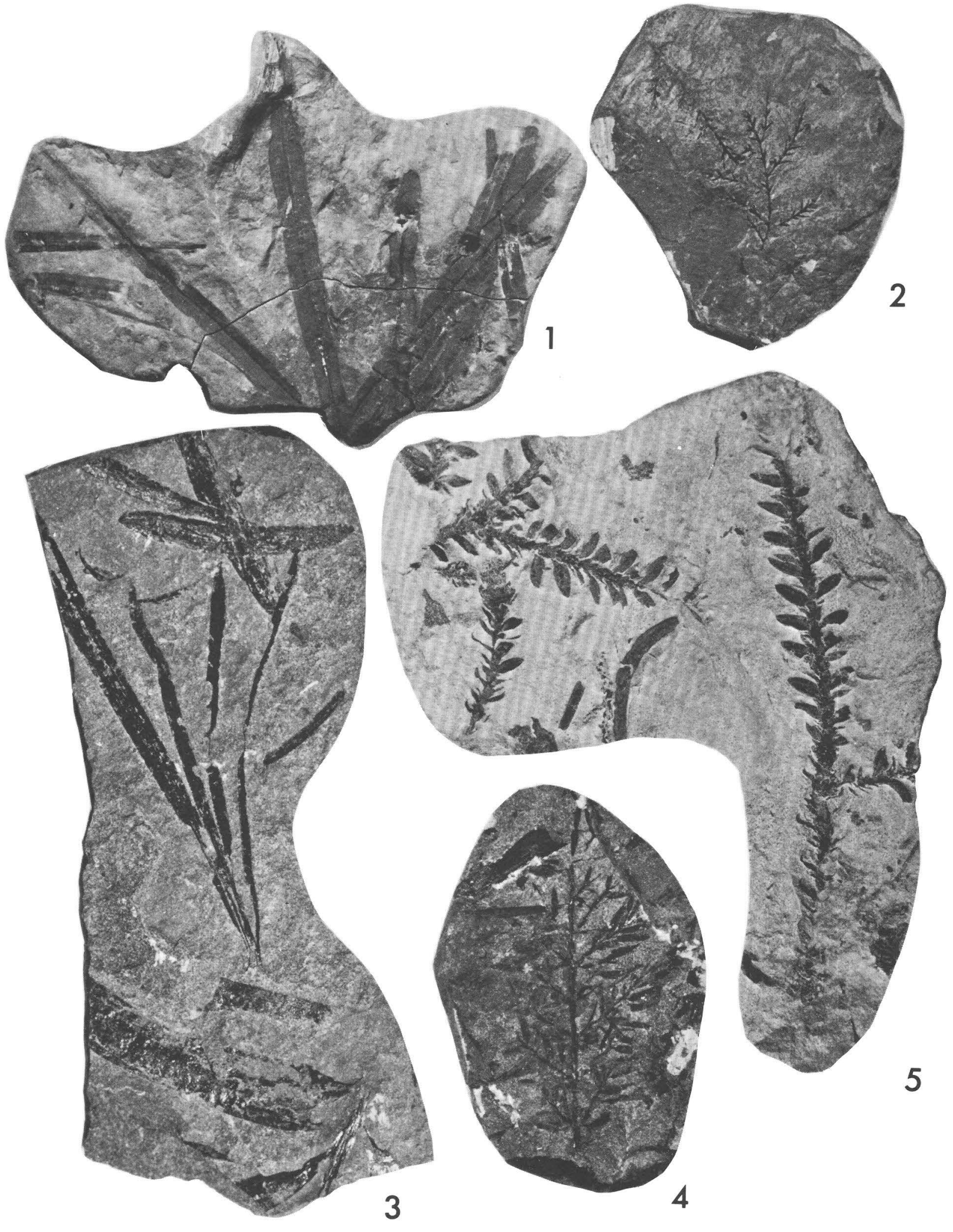


PLATE 6

Figure 1. Podozamites var 2.

2. Podozamites var 15 .

3,4. Podozamites var 7 .

5. Podozamites var 9. 


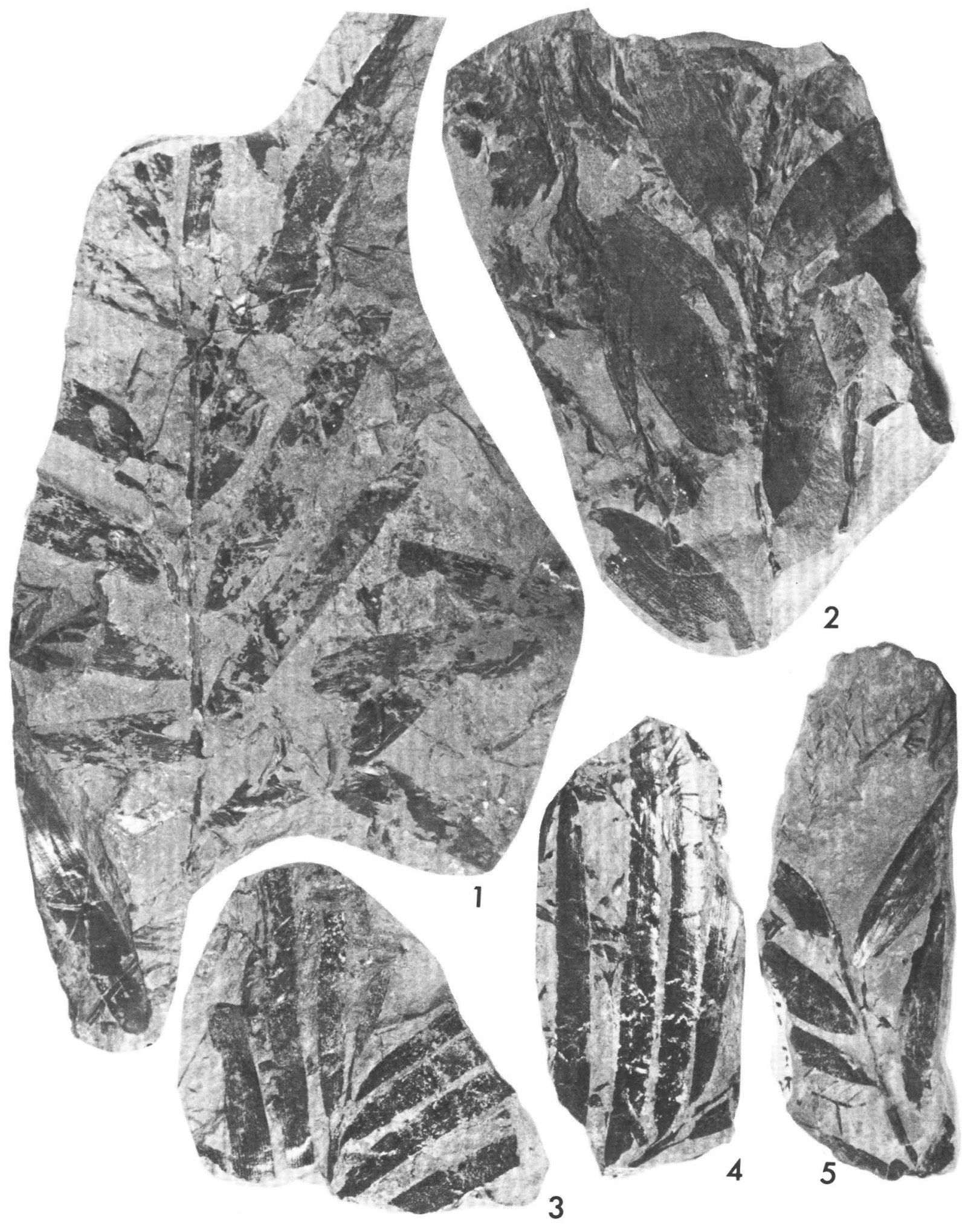


PLATE 7

Figure 1. cf. Ampelopsis multesima Hollick.

2. Cissites comparabilis Hollick.

3. Pseudoprotophyllum cf. P. dentatum Hollick.

4. cf. Platanus latiloba Seward.

5. ?Cissites sp. 

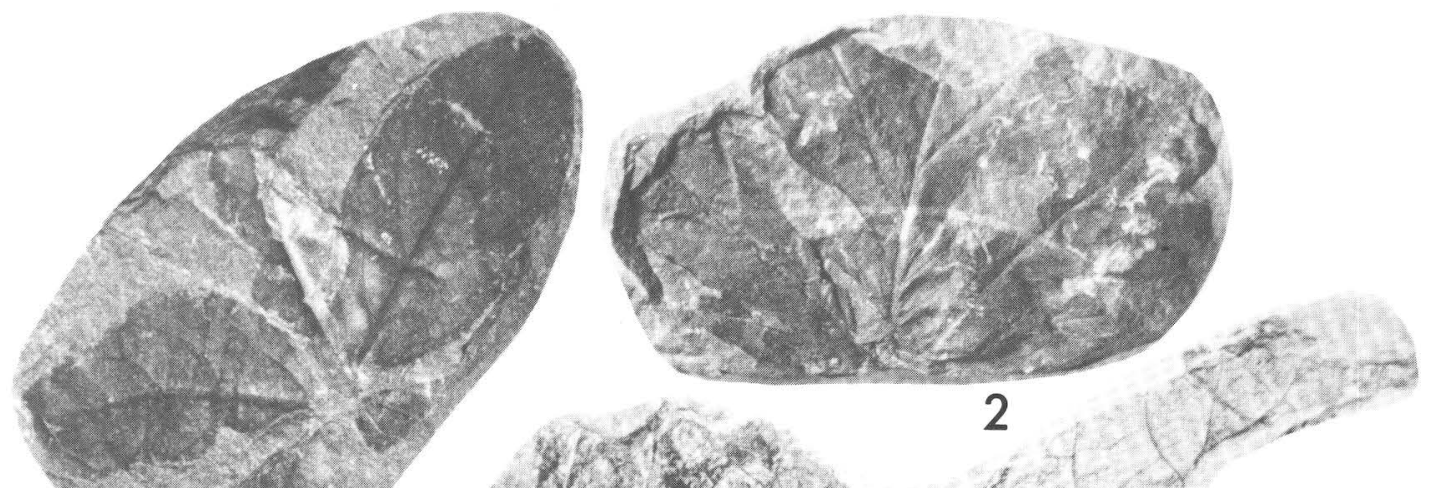

$8 x^{2}+x^{2}+2 y$

1.
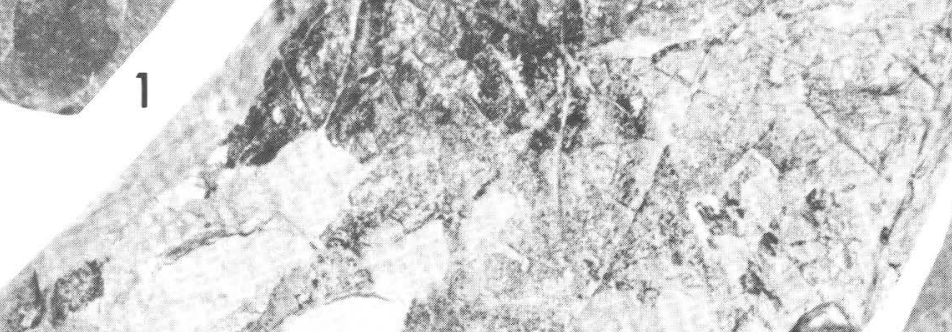

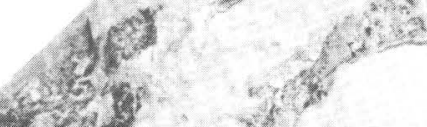

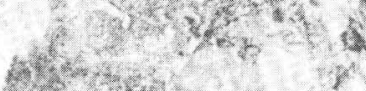

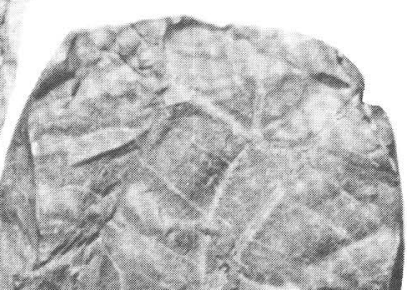

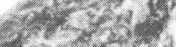

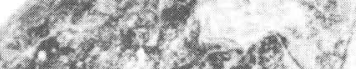

$x+1 x^{2}+2 x$

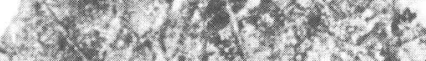

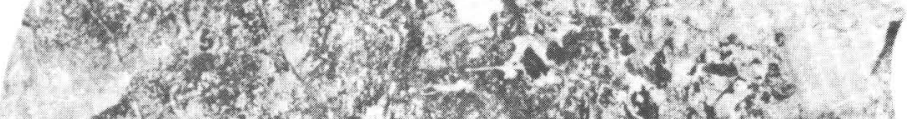

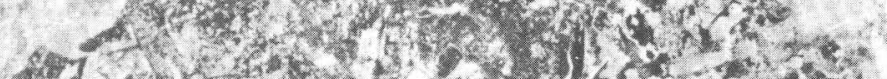

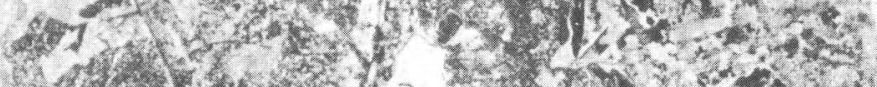

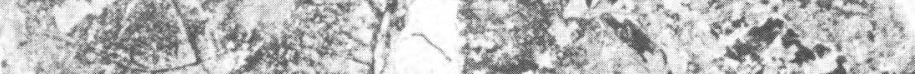

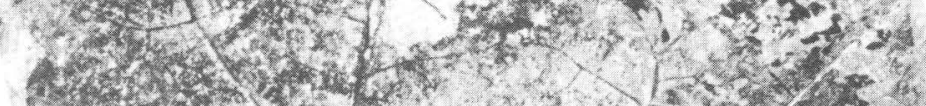

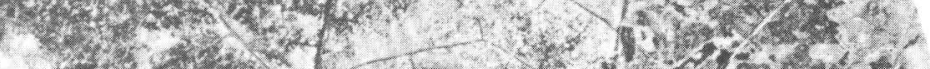

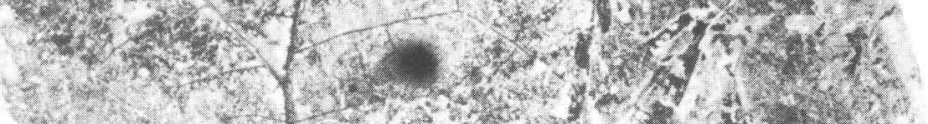

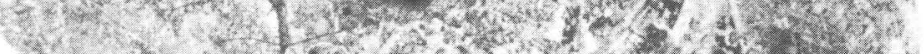

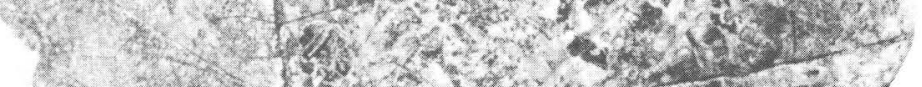

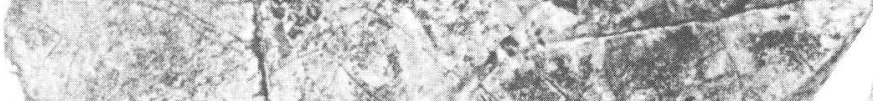

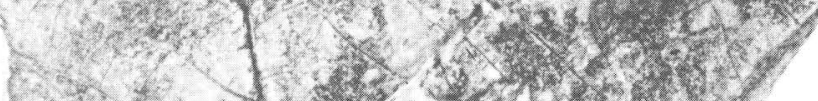

(6.5.

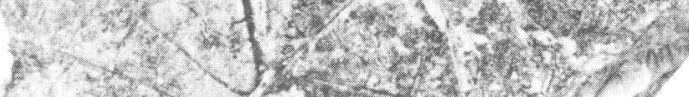
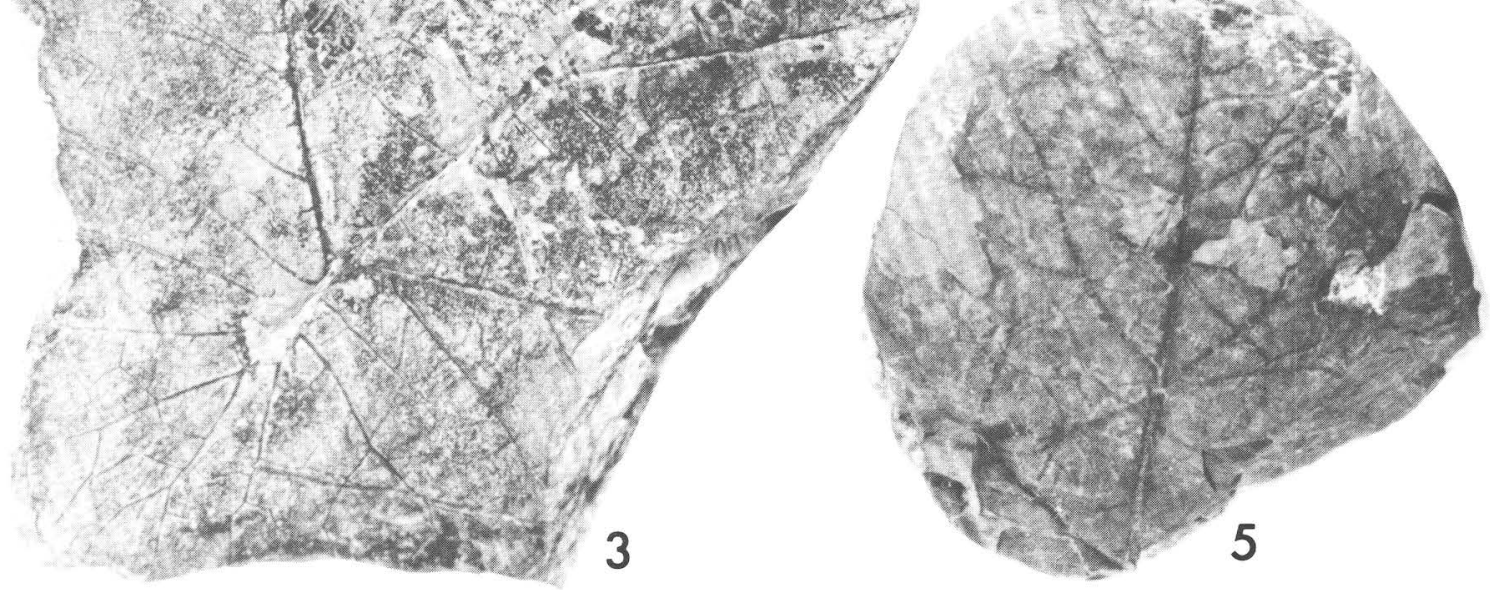



\section{DINOFLAGELLATE AND ACRITARCH ASSEMBLAGES \\ FROM THE NANUSHUK GROUP \\ (ALBIAN-CENOMANIAN) AND THE TOROK \\ FORMATION (ALBIAN), UMTAT TEST WELL 11, NATIONAL PETROLEUM RESERVE IN ALASKA, NORTHERN ALASKA}

By Fred E. May

\section{ABSTRACT}

About 50 species of dinoflagellates and acritarchs are reported from the Nanushuk Group (Albian-Cenomanian) and the Torok Formation (Albian) of Umiat test well 11, National Petroleum Reserve in Alaska, northern Alaska. Twenty-four samples were examined: four from the Ninuluk Formation (three were barren); twelve from the Killik Tongue of the Chandler Formation (three yielded sufficient species to report); six from the Grandstand Formation (four yielded sufficient species to report); and two from the upper part of the Torok Formation (both yielded sufficient species to report).

Although many of the taxa observed appea: new, several are useful in making age determinations and for correlations with formations in the Canadian districts of Mackenzie and Alberta. The presence of dinoflagellates and acritarchs indicates that the Nanushuk Group units studied (Killik Tongue of the Chandler Formation and the Grandstand Formation) and the upper part of the Torok Formation are predominantly marine.

The Nanushuk Group is considered to be of middle to late Albian age on the basis of dinoflagellates and acritarchs, although a Cenomanian Age cannot be ruled out for the Killik Tongue and the Ninuluk Formation.

\section{INTRODUCTION}

Between 1944 and 1953 the U.S. Navy conducted a program of petroleum exploration in NPR-4 (Naval Petroleum Reserve No. 4) (now called NPRA, the National Petroleum Reserve in Alaska), northern Alaska. A main part of this program was the drilling of numerous test wells and core tests, including Umiat test well 11 (Collins, 1958a). This paper on the Nanushuk Group (Albian-Cenomanian) and Torok Formation (Albian) in Umiat test well 11 is the first published report on dinoflagellate and acritarch assemblages from any of these wells.
To date, very little literature exists for North Slope dinoflagellate and acritarch assemblages. Virgil D. Wiggins (1973, 1975) of Standard 0il Co. of California has published some new genera and species from Jurassic and Lower Cretaceous sediments of the North Slope of Alaska. In adjacent Arctic and Subarctic Canada, several biostratigraphically helpful studies have been published (Brideaux, 1971; Singh, 1971; Brideaux and McIntyre, 1975; and Brideaux and Fisher, 1976). In this report this attempted correlation and age determination of the Nanushuk Group are based primarily on comparison with Canadian assemblages. Ora1 communications with Wiggins (1977) have also been helpful in determining ages and in understanding some of the complexities inherent in the assemblages.

This preliminary report is the first in a series to be published on dinoflagellate and acritarch assemblages from some of the NPR-4 test we11s, especially from Albian-Cenomanian Age units. Assemblages are presently being studied from Fish Creek test well 1, Simpson core test 25, and Grandstand test well 1 .

\section{METHODS}

Standard palynological maceration procedures were employed in processing the core samples. HC1 was used to digest carbonates, HF was used to digest silicates, and Schulze's solution was used to break down unwanted organics. Nitex monofilament sieve cloth was used to concentrate the dinoflagellates and acritarchs. Fossil residues were mounted in glycerin jelly on microscope slides.

\section{SLIDE STORAGE}

Microscope slides of Umiat test well 11 are stored in the palynological laboratories of the U.S. Geological Survey, Denver, Colo., and are assigned Denver Paleobotany Locality Number D4060. 


\section{STUDY LOCALITY}

Umiat test we11 11, near Umiat on the North Slope of Alaska, was drilled at lat $69^{\circ} 24^{\prime} 29^{\prime \prime}$ N., long $152^{\circ} 05^{\prime} 58^{\prime \prime} \mathrm{W}$. to test the petroleum production possibilities of the sandstone beds of the Grandstand Formation on the northern, downthrown side of a fault that parallels the axis of an anticline and to determine whether oil could be produced from any younger sandstone units (Collins, 1958a).

The well penetrated the Upper Cretaceous Tuluvak Tongue of the Prince Creek Formation (about $158 \mathrm{~m}$ thick), the Seabee Formation (about $427 \mathrm{~m}$ thick), the Ninuluk Formation (about $37 \mathrm{~m}$ thick), the Lower Cretaceous Killik Tongue of the Chandler Formation (about $76 \mathrm{~m}$ thick), the Grandstand Formation (about $228 \mathrm{~m}$ thick), and the upper $61 \mathrm{~m}$ of the Torok Formation (the Topagoruk Formation of Collins, 1958a). This study reports on the dinoflagellate and acritarch assemblages recovered from cores taken in the Ninuluk Formation, the Killik Tongue of the Chandler Formation, the Grandstand Formation, and the upper part of the Torok Formation; this is an interval from 622 to $1,006 \mathrm{~m}$. These formations, except for the Torok, compose the Nanushuk Group in this area.

\section{DISCUSSION OF LITHOLOGIES}

In general, dinoflagellate and acritarch recovery is best in marine shales and silty sandstones. Several intervals of these 1ithologies were sampled in Umiat test we11 11. Recovery was sporadic, but often good.

The Ninuluk Formation $(622-658 \mathrm{~m})$ is mainly sandstone; however, a shale interval occurs from 638 to $641 \mathrm{~m}$. The top of the shale interval was cored, and sparse dinoflagellate and acritarch assemblages were recovered from one sample (sample 38 at $639 \mathrm{~m}$ ).

The Killik Tongue of the Chandler Formation $(658-737 \mathrm{~m})$ is about half sandstone and half shale. Several shale intervals were cored, and often diverse assemblages were recovered from samples at 658,676 , and $689 \mathrm{~m}$ (samples 41a, 46 , and 50 , respectively). Other samples were either barren or contained very sparse dinoflagellates and acritarchs.

The Grandstand Formation $(737-937 \mathrm{~m})$ is also about half sandstone and half shale. Several shale intervals were cored. Diverse assemblages were recovered from 823, 862, and $893 \mathrm{~m}$ (samples 55, 56, and 59, respectively). Samples near 774 and $865 \mathrm{~m}$ (samples 54a and 58) yielded very sparse assemblages.

The upper part of the Torok Formation (originally called Topagoruk Formation) was also cored from 1,002 to $1,006 \mathrm{~m}$. This interval is entirely shale. A core taken near $1,006 \mathrm{~m}$ (sample 61) yielded diverse and we11-preserved dinoflagellates and acritarchs.

\section{CHARACTERIZATION OF DINOFLAGELLATE AND ACRITARCH ASSEMBLAGES BY SAMPLE}

The ranges of characteristic dinoflage1lates and acritarchs from Umiat test well 11 are shown by sample on table 8 . The taxa listed on table 8 and in the text are illustrated in plates 8-12.

Sample 4la $(658 \mathrm{~m})$, top of Killik Tongue of Chandler Formation.--About 25 species of dinoflagellates and acritarchs were recovered. Age diagnostic forms are:

Cleistosphaeridium multispinosum (Singh) Brideaux, 1971, middle Albian to early Cenomanian;

Oligosphaeridium irregulare (Pocock) Davey and Williams, 1969, early to middle Albian of subarctic Canada; range extended elsewhere.

Age: possibly middle Albian. The extended range of 0 . irregulare (BarremianMaestrichtian) elsewhere suggests that the age of the sample could extend into the Cenomanian.

Environment of deposition: marine.

Sample $46(685 \mathrm{~m})$, upper half of Killik Tongue of the Chandler Formation.--About 22 species of dinoflagellates and acritarchs were recovered. Many of these appear to be new species and are presently not age-diagnostic. Age: not determined.

Environment of deposition: marine.

Sample $50(731 \mathrm{~m})$, near base of Killik Tongue of Chandler Formation.--About 10 species of dinoflagellates and acritarchs were recovered. One of these species, Cleistosphaeridium multispinosum, suggests an age of middle Albian to early Cenomanian.

Age: middle Albian to early Cenomanian. Environment of deposition: marine.

Sample 55 (762 m), upper part of Grandstand Formation.--About 11 species of dinoflagellates and acritarchs were recovered. Forms that suggest an age for the sample are:

New Genus A. Albian, based on oral communications with Virgil D. Wiggins, Standard Oil Co. of California (1977), and Hideyo Haga of Anderson, Warren and Associates (1977);

Cleistosphaeridium multispinosum, middle Albian to early Cenomanian;

Luxadinium propatulum Brideaux and McIntyre, 1975, middle Albian.

Age: middle Albian.

Environment of deposition: marine.

Sample $56(860 \mathrm{~m})$, lower half of Grandstand Formation.--About 13 species of dinoflagellates and acritarchs were recovered. Forms that suggest an age for this sample are: 
Table 8.--Ranges of characteristic dinoflagellates and acritarchs from the Nanushuk Group and Torok Formation of Umiat test well 11, North Slope, Alaska

[Brid. indicates Brideaux; McInt. indicates McIntyre]

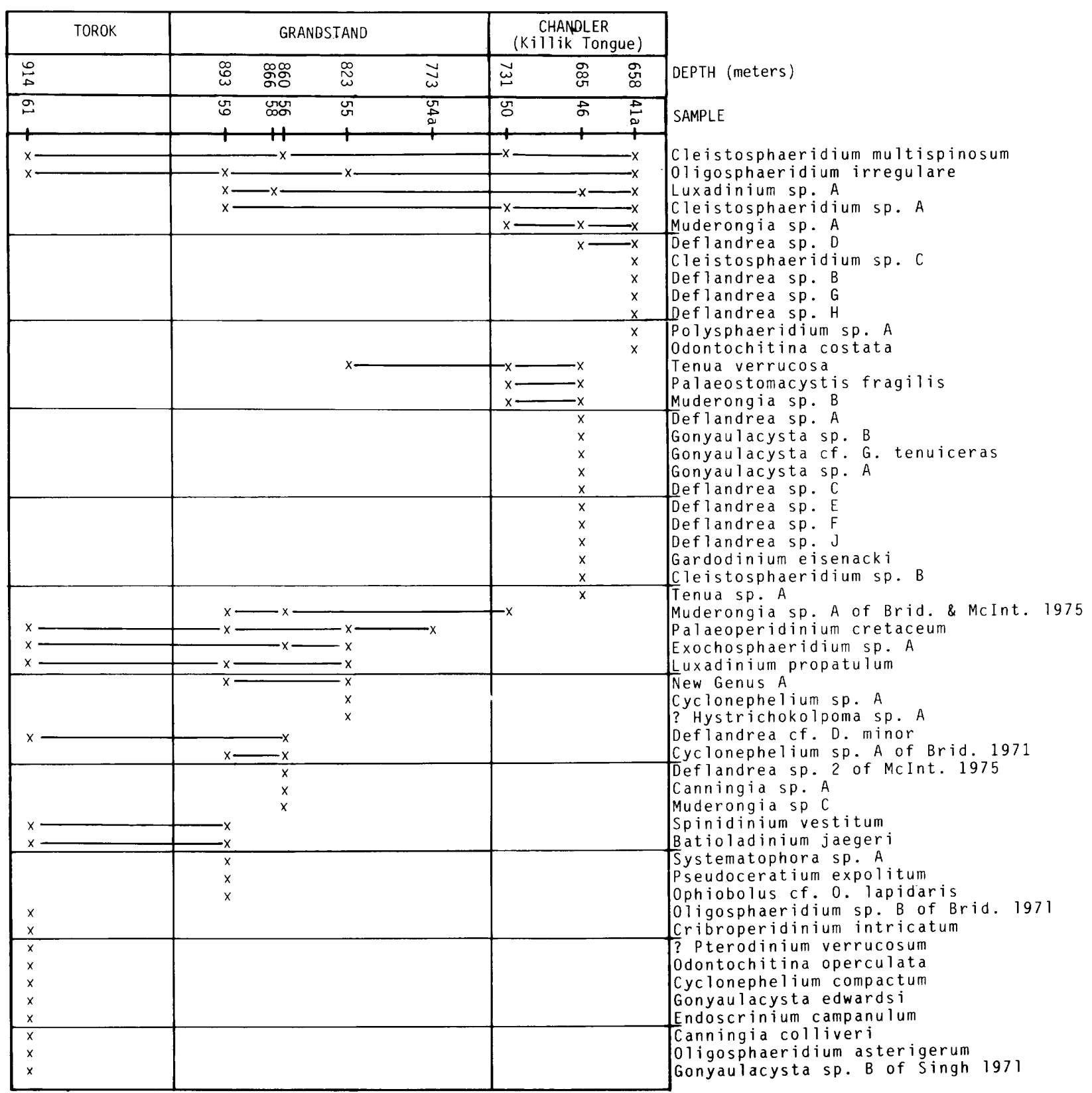

Cleistosphaeridium multispinosum, middle Albian to early Cenomanian;

Muderongia sp. A. of Brideaux and McIntyre (1975), Aptian to early Albian.

Age: early to middle Albian.

Environment of deposition: marine.

Sample $58(865 \mathrm{~m})$, lower half of Grandstand Formation.--About four species of dinoflage1lates and acritarchs were recovered. Only one species was observed that suggests an age: Cyclonephelium sp A of Brideaux (1971) from the early-late Albian.

Age: possibly early-late Albian.

Environment of deposition: marine.

Sample $59(893 \mathrm{~m})$, lower part of Grandstand Formation.--About 19 species of dinoflagellates and acritarchs were recovered. Forms that suggest an age for this sample are: 
Spinidinium vestitum Brideaux, 1971, late Albian to early Cenomanian;

Luxadinium propatulum, middle Albian;

New Genus A. Albian;

Pseudoceratium expolitum Brideaux, 1971, middle to late Albian;

Batioladinium jaegeri (Alberti) Brideaux, 1975, early Valanginian to late Albian.

Age: middle Albian.

Environment of deposition: marine.

Sample 61 (1,005 m), uppermost Torok Formation.--About 30 species of dinoflagellates and acritarchs were recovered. Forms that suggest an age for this sample are:

Oligosphaeridium sp. B of Brideaux (1971), late Albian;

Spinidinium vestitum, late Albian to early Cenomanian;

Luxadinium propatulum, middle Albian;

Cleistosphaeridium multispinosum, middle Albian to early Cenomanian;

Batioladinium jaegeri, early Valanginian to late Albian;

Cribroperidinium intricatum Davey, 1969, Albian;

Cyclonephelium compactum Deflandre and Cookson, 1955, Albian to Santonian.

Age: probably late-middle Albian.

Environment of deposition: marine.

\section{AN ASSEMBLAGE FROM THE NINULUK FORMATION}

Sample $38(640 \mathrm{~m})$, from the middle part of the Ninuluk Formation, yielded an assemblage much like the ones seen in the Killik Tongue of the Chandler Formation (samples 41a, 46, and 50). This sample is being considered as part of a separate problem and will not be discussed in detail here. The present assumptions, based on this Ninuluk assemblage, are that (1) probably no disconformity exists between the Ninuluk and Chandler Formations here, and (2) the environments of deposition of the parts of both units yielding the assemblages are similar, the Ninuluk probably being somewhat closer to shore. The age of the Ninuluk Formation cannot presently be determined from the dinoflagellates present; many of the forms appear to be undescribed.

\section{POSITION OF THE ALBIAN-CENOMANIAN BOUNDARY}

Although the presence of Cenomanian sediments cannot now be determined from the dinoflagellate and acritarch assemblages observed, still, the presence of Cleistosphaeridium multispinosum (Singh) Brideaux, 1971 in samples $41 \mathrm{a}$ and 50 of the Killik Tongue of the Chandler Formation suggests that those samples could be as young as early Cenomanian. Considering the similarity between the Killik and Ninuluk dinoflagellates, it seems unlikely that a disconformity exists between these two units.
A marked difference exists between the assemblages of the Grandstand and the Killik, however. Although this may only reflect change in paleoenvironment, it may reflect a disconformity, and the poorly known Killik-Ninuluk assemblages may in fact be of younger Cenomanian Age.

Foraminiferal assemblages (Sliter, this volume) indicate Albian Ages for samples to the top of the Grandstand Formation. Poor recovery precludes age dating through the Killik; however, Cenomanian foraminifera are reported from the Ninuluk.

Thus, on the basis of dinoflagellates and foraminifera, it can be inferred that the Albian-Cenomanian boundary lies between the Grandstand and the Killik. At this depth (736 m) a thin limestone layer exists that may represent the boundary; it is the only limestone layer on the entire log.

\section{CORRELATION WITH FORMATIONS IN THE CANADIAN ARCTIC}

Comparison with the work of Brideaux and McIntyre (1975) makes possible a general correlation of Nanushuk Group units of Umiat test well 11 with the upper part of the Langton Bay Formation (Aptian-lower Albian) and the Horton River Formation (middle Albian) from the District of Mackenzie, western Arctic Canada. Six dinoflagellate taxa are common to both areas:

1. Cleistosphaeridium multispinosum (Singh) Brideaux, 1971;

2. Palaeoperidinium cretaceum Pocock, 1962, ex Davey, 1970;

3. Batioladinium jaegeri (Alberti) Brideaux, 1975;

4. Muderongia sp. A of Brideaux and McIntyre (1975);

5. Cyclonephelium compactum Deflandre and Cookson, 1955; and

6. Oligosphaeridium irregulare (Pocock)

Davey and Williams, 1969.

Although a detailed correlation is not possible at present, the concurrent ranges of these taxa in Brideaux and McIntyre (1975) would tend to suggest that the Nanushuk Group in Umiat test we11 11 is not older than early Albian and that it may be no older than middle Albian.

\section{CORRELATION WITH FORMATIONS IN CENTRAL ALBERTA, CANADA}

Comparison with the work of Brideaux (1971) makes possible a general correlation of the Nanushuk Group of Umiat test well 11 with the Peace River and Lower Shaftsbury Formations of west-central Alberta, and with the Joli Fou Formation, Viking Pelikan Formation, and Upper Shale of south-central Alberta. Eleven Nanushuk dinoflagellate taxa also occur in the central Alberta formations: 
1. Palaeoperidinium cretaceum. Pocock, 1962, ex Davey, 1970;

2. Oligosphaeridium irregulare (Pocock)

Davey and Williams, 1969;

3. Odontochitina operculata (0. Wetzel)

Deflandre and Cookson, 1955;

4. Canningia colliveri Cookson and Eisenack, 1960;

5. Cleistosphaeridium multispinosum Brideaux, 1971;

6. Oligosphaeridium anthophorum (Cookson and Eisenack) Davey, 1969;

7. Pseudoceratium expolitum Brideaux, 1971

8. Palaeostomacystis fragilis Cookson and Eisenack, 1962; 1969;

9. Cribroperidinium intricatum Davey,

10. Batioladinium jaegeri (Alberti) Brideaux, 1975; and

11. Spinidinium vestitum Brideaux, 1971 .

The concurrent ranges for these taxa, reported in Brideaux (1971), suggest that the age of the Nanushuk Group is late-middle to late Albian.

\section{CONCLUSIONS}

Diverse dinoflagellate and acritarch assemblages are present in the upper part of the Torok Formation, the Grandstand Formation, the Killik Tongue of the Chandler Formation, and in at least one interval of the Ninuluk Formation.

The upper part of the Torok and the Grandstand appear to be of middle to late Albian age, whereas the Killik Tongue of the Chandler may be as young as early Cenomanian. Assemblages of the Ninuluk did not yield agedistinctive forms, although the one assemblage reported is very similar to those seen in the Killik Tongue of the Chandler, suggesting a similar age and paleoenvironment.

The Albian-Cenomanian boundary is inferred to lie between the Grandstand and Killik. This inference is based mainly on foraminiferal assemblages (Sliter, this volume) and on differences in dinoflagellate assemblages between the Grandstand and Killik.

On the basis of the occurrence of dinoflagellates and acritarchs, parts of the Ninuluk, Killik, and Grandstand and the upper part of the Torok are interpreted as marine. The greatest species diversity is in the upper part of the Torok, suggesting deposition farthest from shore. The lower species diversities found in the units above the Torok suggest that they were deposited closer to shore than the Torok, but the relative proximities cannot presently be determined from dinoflagellates of these units. 


\section{PLATE 8}

Figures 1- 2. Canningia sp. A., length $56 \mu \mathrm{m}$.

3. Tenua sp. A., length $76 \mu \mathrm{m}$.

4. Cleistosphaeridium sp. A., length $34 \mu \mathrm{m}$.

5- 8. Cyclonephelium sp A of Brideaux 1971, length range 52-84 $\mu \mathrm{m}$.

9-10. Cyclonephelium compactum Deflandre and Cookson 1955.

11. Canningia colliveri Cookson and Eisenack 1960 of Singh 1971, length $70 \mu \mathrm{m}$.

12. Systematophora sp., length $40 \mu \mathrm{m}$.

13. Tenua verrucosa Sarjeant 1968, length $34 \mu \mathrm{m}$.

14-15. New Genus A., length $104 \mu \mathrm{m}$.

16-17. Gonyaulacysta sp. A of Singh 1971, length $100 \mu \mathrm{m}$.

18-19. Gonyaulacysta sp. A., length $64 \mu \mathrm{m}$.

20. Gonyaulacysta edwardsi (Cookson and Eisenack) Clarke and Verdier 1967 of Singh 1971 , length $140 \mu \mathrm{m}$. 

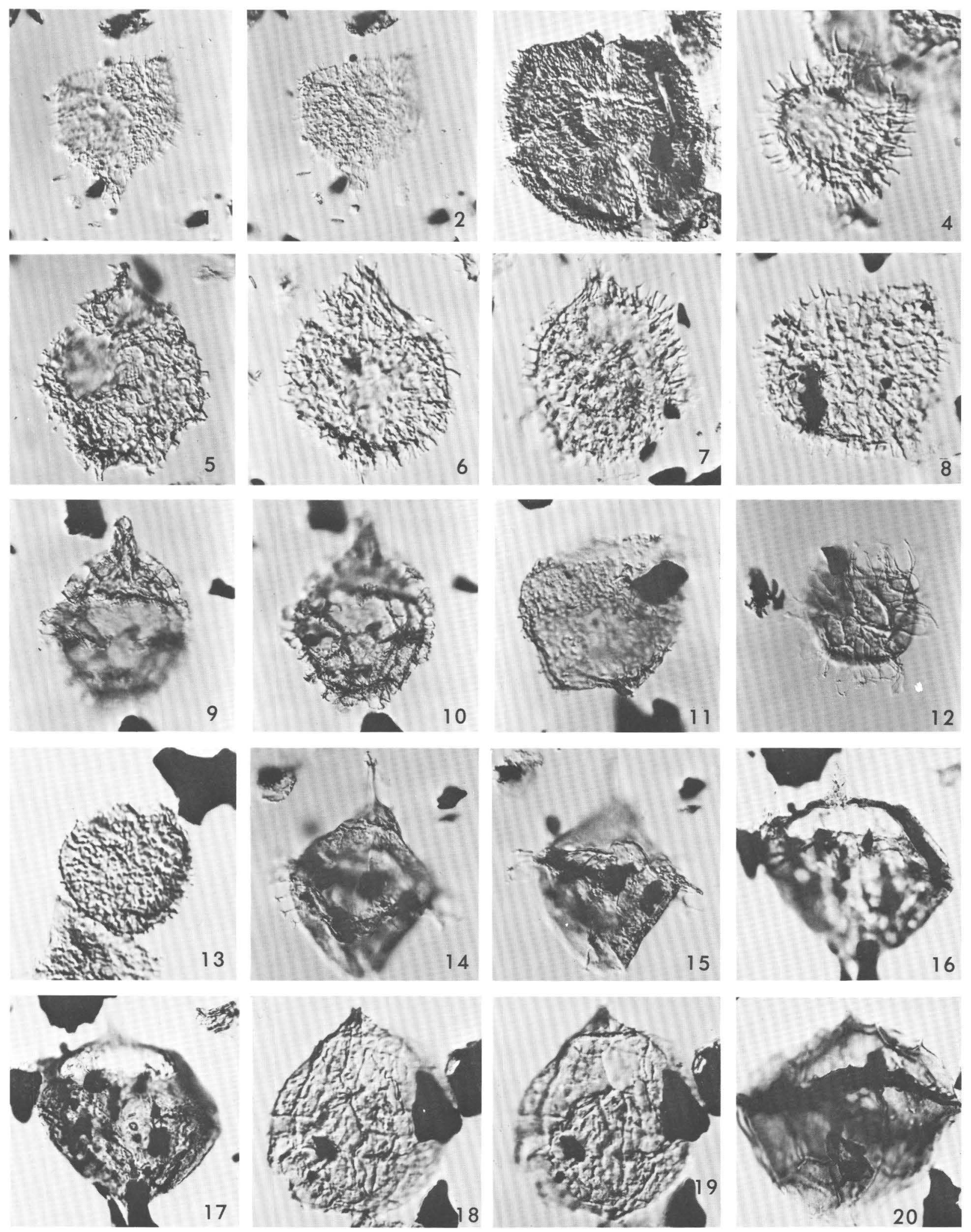


\section{PLATE 9}

Figure 1. Cribroperidinium intricatum Davey 1969, length $102 \mu \mathrm{m}$.

2. Gonyaulacysta edwardsi (Cookson and Eisenack) Clarke and Verdier 1967 of Singh 1971, length $140 \mu \mathrm{m}$.

3. Gonyaulacysta sp. B., length $84 \mu \mathrm{m}$.

4- 5. Gonyaulacysta cf. G. tenuiceras (Eisenack) Sarjeant 1969 of Davey and Verdier 1971, length $74 \mathrm{\mu m}$.

6. Endoscrinium campanulum (Gocht) Vozzhennikova 1967, length $110 \mu \mathrm{m}$.

7, 11-12. Muderongia sp. A., length range 60-80 $\mu \mathrm{m}$.

8. Odontochitina operculata (0. Wetzel) Deflandre and Cookson 1955, length $142 \mu \mathrm{m}$.

9-10, 13. Muderongia sp. B., length 70-78 $\mu \mathrm{m}$.

14-15. Muderongia sp. A. of Brideaux and McIntyre (1975), length $80 \mu \mathrm{m}$.

16. Muderongia sp. C., width of lateral horn $14 \mu \mathrm{m}$. 

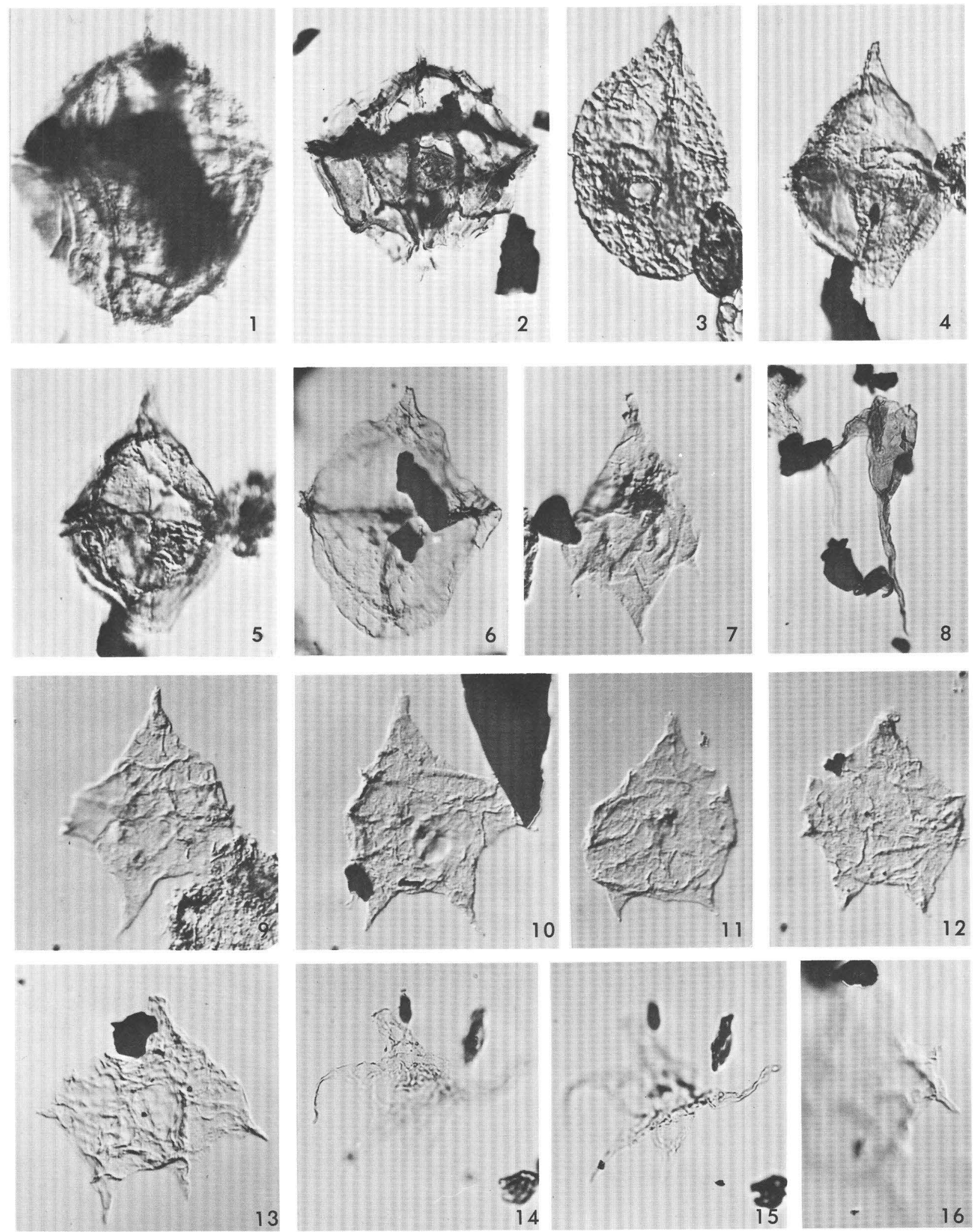
PLATE 10

Figures 1- 2. Muderongia sp. C., length $138 \mu \mathrm{m}$.

3- 4. Pseudoceratium expolitum Brideaux 1971, length range 84-108 $\mu \mathrm{m}$.

5- 6. Cleistosphaeridium sp. A., length range 28-32 $\mu \mathrm{m}$.

7. Cleistosphaeridium sp. B., length of main body $30 \mu \mathrm{m}$.

8. Cleistosphaeridium sp. C., length of main body $42 \mu \mathrm{m}$.

9-10. Oligosphaeridium irregulare (Pocock) Davey and Williams 1969, length of main body 36 $\mu \mathrm{m}$.

11. Polysphaeridium sp. A., length of main body $60 \mu \mathrm{m}$.

12-13. Cleistosphaeridium multispinosum (Singh) Brideaux 1971.

14-15. Oligosphaeridium anthophorum (Cookson and Eisenack) Davey 1969, length of main body $60 \mu \mathrm{m}$. 

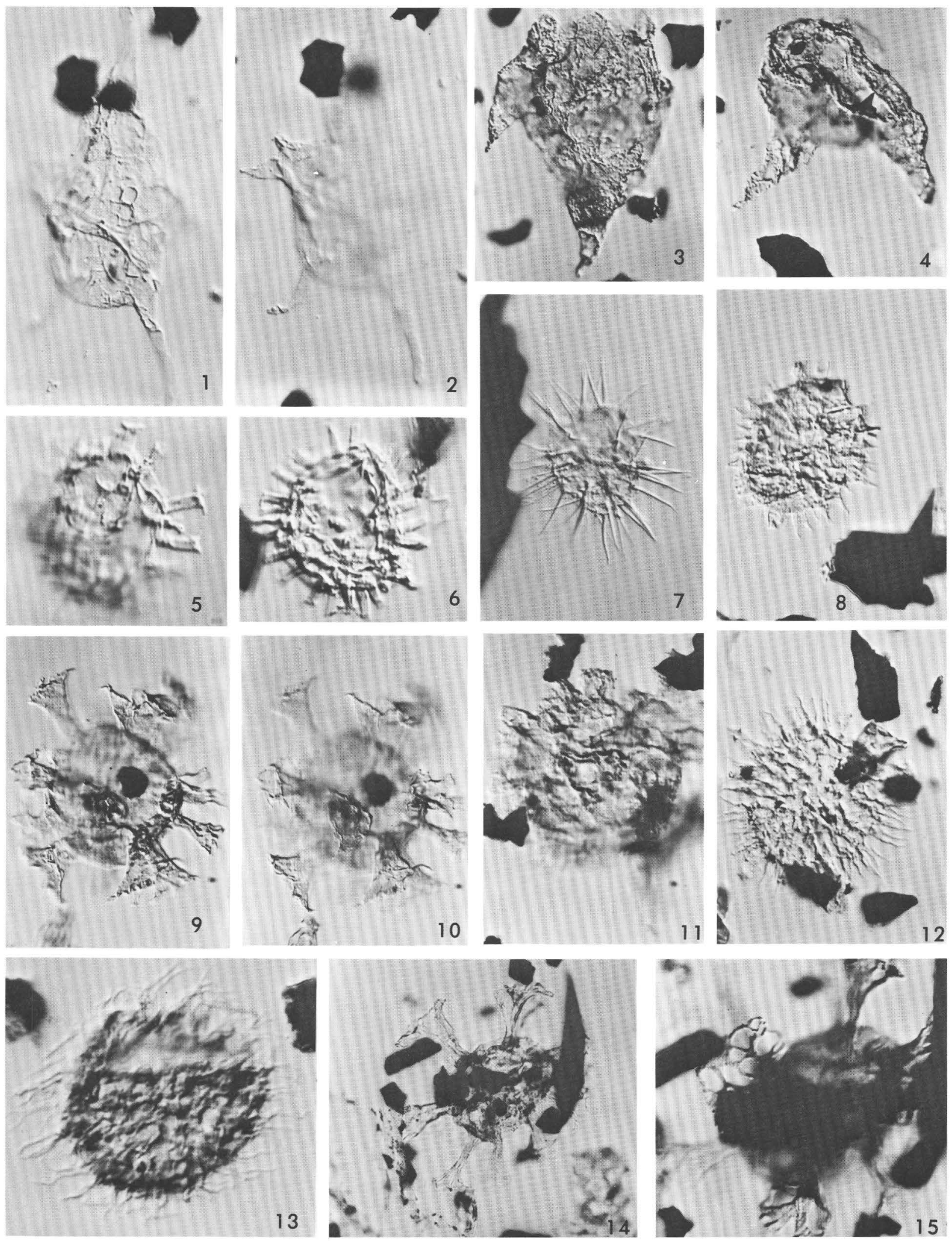


\section{PLATE 11}

Figure 1. Oligosphaeridium asterigerum (Gocht) Davey and Williams 1969, length of upper process $30 \mu \mathrm{m}$.

2. Exochosphaeridium sp. A., length of main body $76 \mu \mathrm{m}$.

3. Aptea polymorpha Eisenack 1958, length $76 \mu \mathrm{m}$.

4,14. Deflandrea sp. A., length range 60-72 $\mu \mathrm{m}$.

5- 7. Spinidinium vestitum Brideaux 1971, length range $64-70 \mu \mathrm{m}$.

8. Deflandrea sp. 2 of McIntyre (1973), length $62 \mu \mathrm{m}$.

9. Deflandrea cf. D. minor Cookson and Eisenack 1960, length $50 \mu \mathrm{m}$.

10. Deflandrea sp. B., length $50 \mathrm{\mu m}$.

11. Deflandrea sp. C., length $70 \mu \mathrm{m}$.

12. Deflandrea sp. D., length $66 \mu \mathrm{m}$.

13,20. Luxadinium sp. A., length range 60-74 $\mu \mathrm{m}$.

15. Deflandrea sp. E., length $64 \mu \mathrm{m}$.

16. Deflandrea sp. F., length $68 \mu \mathrm{m}$.

17-18. Deflandrea sp. G., length of both specimens $76 \mu \mathrm{m}$.

19. Deflandrea sp. H., length $60 \mu \mathrm{m}$. 

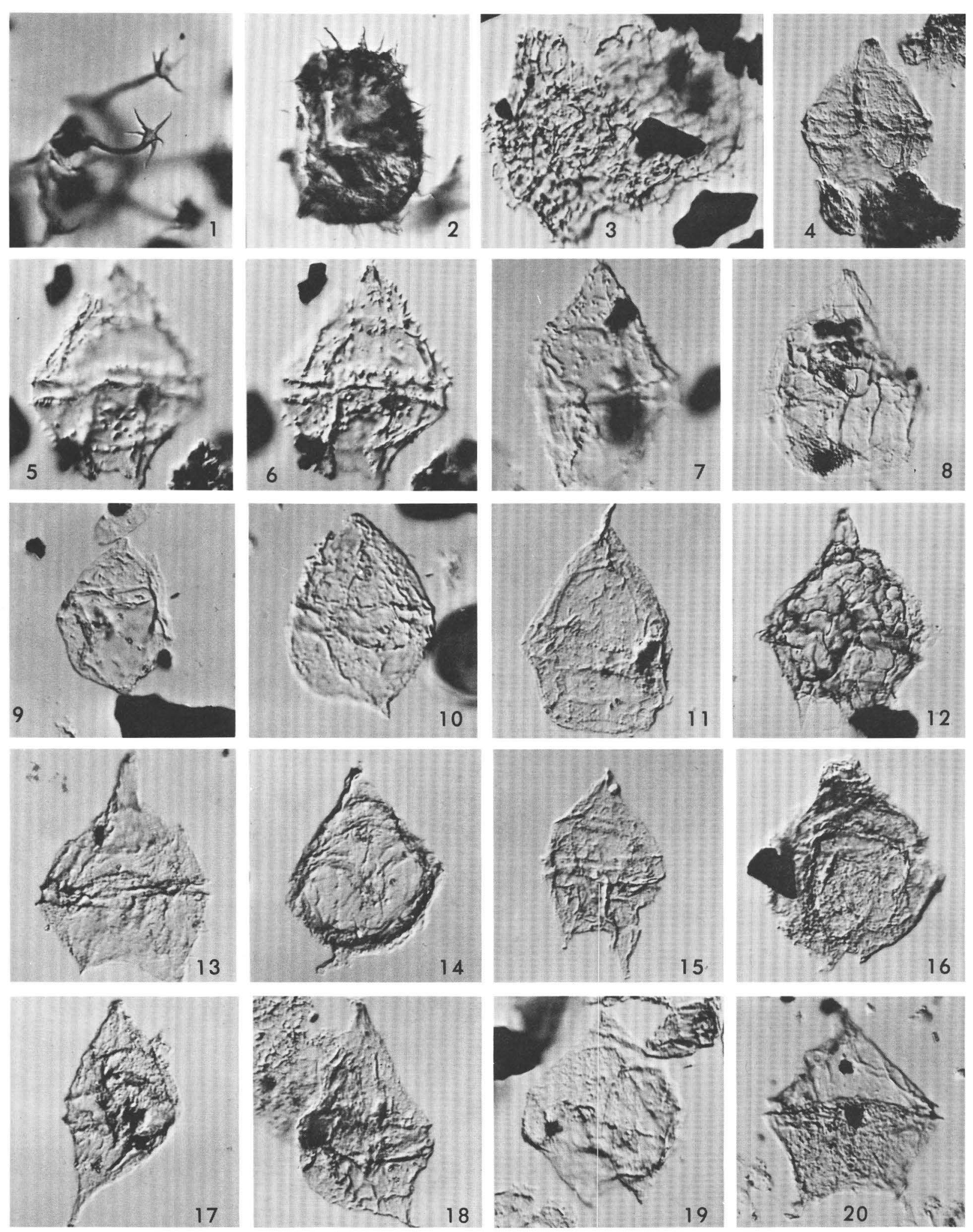


\section{PLATE 12}

Figures 1- 3. Luxadinium sp. A., length range 70-80 $\mu \mathrm{m}$.

4. Deflandrea sp. I., length $80 \mu \mathrm{m}$.

5. Deflandrea sp. J., length $120 \mu \mathrm{m}$.

6. Palaeoperidinium cretaceum Pocock, ex Davey 1970, length $90 \mu \mathrm{m}$.

7- 8. Batioladinium jaegeri (Alberti) Brideaux 1975, length range 142-160 $\mu \mathrm{m}$. 9-10. Luxadinium propatulum Brideaux and McIntyre 1975, length $85 \mu \mathrm{m}$.

11. Ophiobolus cf. O. lapidaris 0. Wetzel 1933, length of main body $58 \mu \mathrm{m}$. 12. Palaeostomacystis fragilis Cookson and Eisenack 1962, length $90 \mu \mathrm{m}$. 

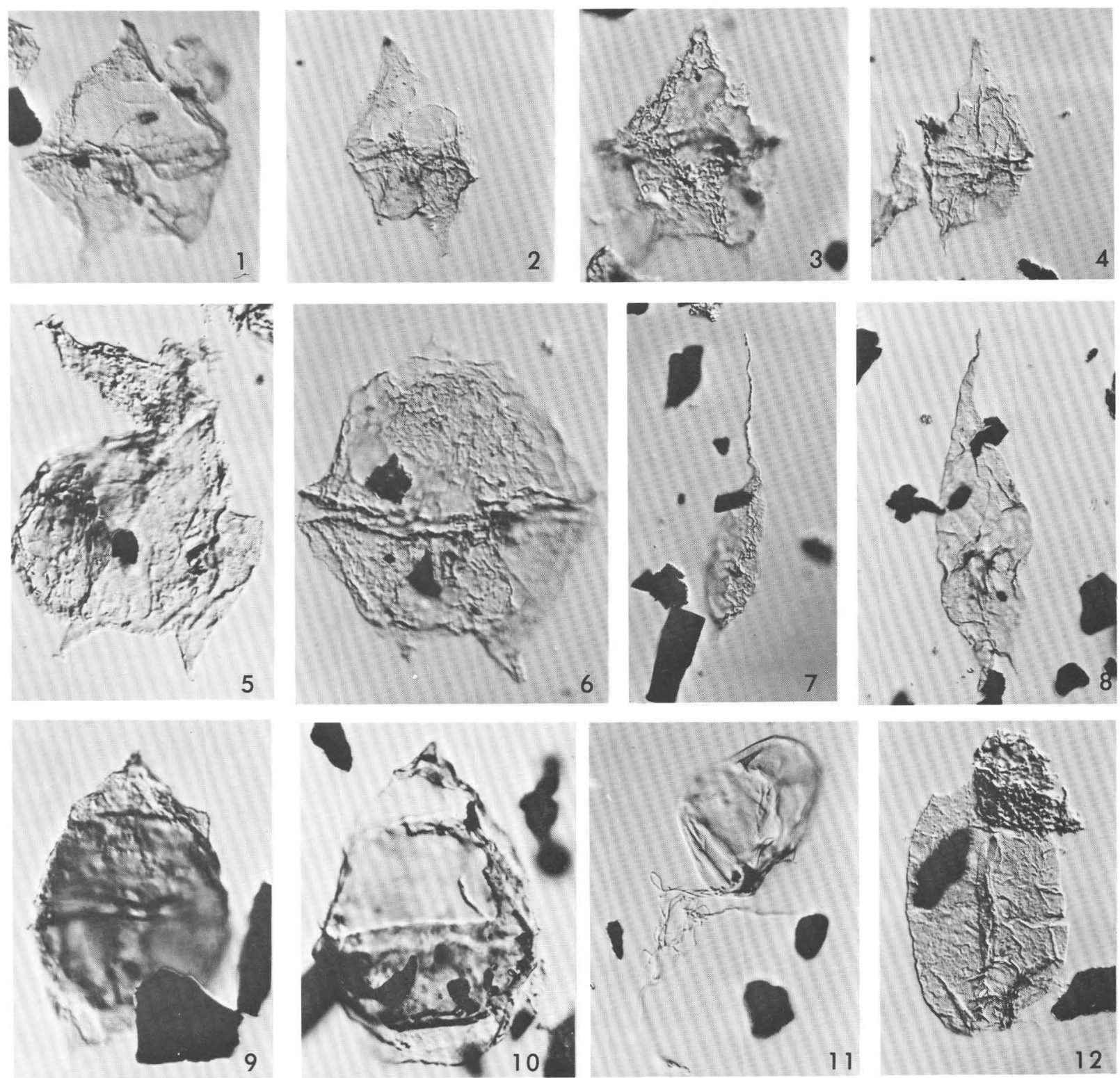


\section{DINOFLAGELLATE AND ACRITARCH ASSEMBLAGES FROM THE GRANDSTAND FORMATION (MIDDLE TO UPPER ALBIAN) OF THE NANUSHUK GROUP, SIMPSON CORE TEST 25, NATIONAL PETROLEUM RESERVE IN ALASKA, NORTHERN ALASKA}

By Fred E. May and Jeffrey A. Stein ${ }^{1}$

\section{ABSTRACT}

Sixty-one species of dinoflagellates and acritarchs are reported from the Grandstand Formation (middle to upper Albian) of Simpson core test 25, National Petroleum Reserve in Alaska, northern Alaska. Nineteen samples were examined from the $203-\mathrm{m}$ interval considered to be Grandstand Formation.

Although many of the observed taxa appear to be new, several are useful in making age determinations. The Grandstand Formation at this locality is considered to be of middle to late Albian age. The presence of dinoflagellates and acritarchs indicates that the Grandstand Formation is predominantly marine.

\section{INTRODUCTION}

During the exploration of NPR-4 (Naval Petroleum Reserve No. 4) (now called NPRA, the National Petroleum Reserve in Alaska) between 1944 and 1953, the U.S. Navy and its contractors drilled 33 shallow holes on the Simpson Peninsula. This locality was of particular interest because of oil seeps that existed in an approximately $52-\mathrm{km}^{2}$ area some $80 \mathrm{~km}$ southeast of Point Barrow near Cape Simpson. Simpson core test 25 was one of 21 shallow wells drilled on the east side of the peninsula near Cape Simpson to determine the origin of the oil seeps. The drilling of core test 25 began in July 1949. It was located near seep 3 , the southernmost seep. Although this was a dry hole, the next well, Simpson core test 26, was the discovery well of the Simpson oil field (Robinson, 1964). This paper on Simpson core test 25 is part of the first series of publications on the dinoflagellate and acritarch assemblages from wells drilled in NPRA.

Because very little literature exists on North Slope dinoflagellate and acritarch assemblages, most palynological comparisons have to be made with published assemblages from the

\footnotetext{
${ }^{1}$ Stanford University, Department of Geology, Stanford, Calif.
}

Arctic and subarctic of adjacent Canada (Brideaux, 1971; Singh, 1971, Brideaux and McIntyre, 1975; Brideaux and Fisher, 1976; and Brideaux, 1977).

METHODS

Standard palynological-maceration procedures were employed in processing core samples. $\mathrm{HCl}$ was used to digest carbonates, HF was used to digest silicates, and Schulze's solution was used to break down unwanted organics. Nitex monofilament sieve cloth $(20 \mu \mathrm{m})$ was used to concentrate the dinoflagellates and acritarchs. Fossil residues were mounted in glycerin jelly on microscope slides.

\section{SLIDE STORAGE}

Microscope slides of Simpson core test 25 are stored in the palynological laboratories of the U.S. Geological Survey, Denver, Colo., and are assigned Denver Paleobotany Locality Number D4044.

\section{STUDY LOCALITY}

Simpson core test 25, near oil seep 3 on the Simpson Peninsula, was drilled approximately $93 \mathrm{~km}$ southeast of Point Barrow at lat $70^{\circ} 56^{\prime} 10^{\prime \prime}$ N. and long $154^{\circ} 42^{\prime} 12^{\prime \prime} \mathrm{W}$. (fig. 45) to locate the source of oil seeping in the vicinity. The well penetrated $33 \mathrm{~m}$ of Gubik Formation (Quaternary), $219 \mathrm{~m}$ of Seabee Formation (Turonian), and $203 \mathrm{~m}$ of Grandstand Formation (Albian) (Robinson, 1964). This paper reports on the dinoflagellate and acritarch assemblages recovered from the continuous core taken in the Grandstand interval. The Grandstand Formation constitutes the lower part of the Nanushuk Group of Albian to Cenomanian Age.

\section{DISCUSSION OF LITHOLOGIES}

In general, dinoflagellate and acritarch recovery is best in marine claystones, shales, siltstones, and silty sandstones. Several 


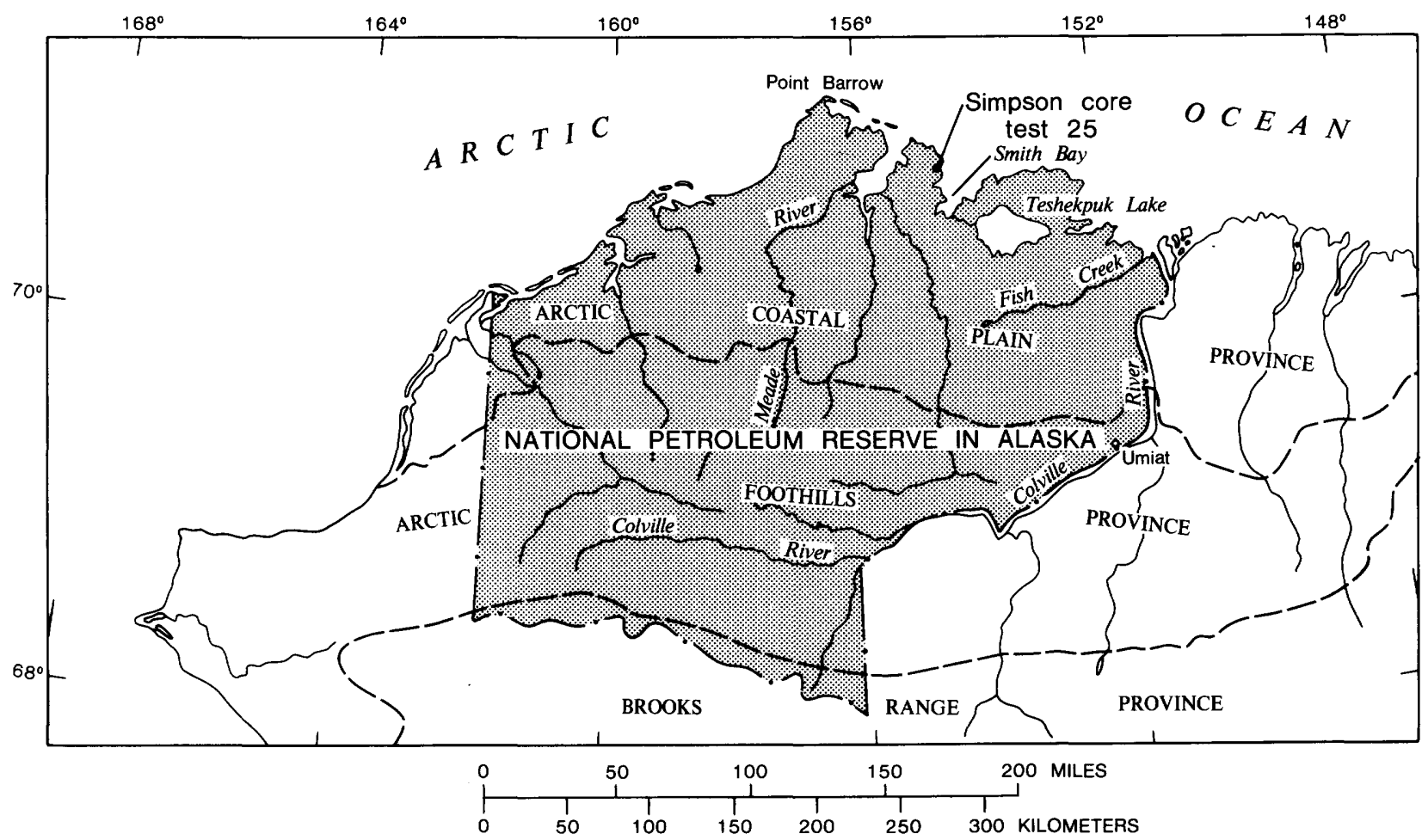

Figure 45.--General map of North Slope, Alaska, showing location of Simpson core test 25 within the National Petroleum Reserve in Alaska (modified from Robinson, 1964).

intervals of these lithologies were sampled in Simpson core test 25 .

More than half of the Grandstand in the well is claystone, clayey shale, or shale (fig. 46). Most samples from these lithologies yielded dinoflagellates and acritarchs. Recovery was fair to good in most samples, with at least adequate recovery occurring at the following depths: 254, 257, 260, 263, 266, 270, 273, 276, $301,309,312,318,334,351,376,412,431$, 447 , and $457 \mathrm{~m}$. Samples at a few other depths were either barren or yielded too few specimens and taxa to be meaningful and were not reported. In general, the lithologies and lack of metamorphism have maintained good preservation in the assemblages.

\section{CHARACTERIZATION OF THE DINOFLAGELLATE AND ACRITARCH ASSEMBLAGES BY SAMPLE}

The ranges of characteristic dinoflagellates and acritarchs from Simpson core test 25 are shown by sample on table 9. The taxa listed on table 9 and in the text are illustrated in plates 13-17. All samples reported on here are considered marine. Species diversities are only approximate, based on the microscope slide examined.

Sample 34 (254 $\mathrm{m})$, top of Grandstand Formation.--Seven species of dinoflagellates were recovered. Age diagnostic forms are:
Cleistosphaeridium multispinosum (Singh) Brideaux, 1971, middle Albian to early Cenomanian;

Cyclonephelium sp. A of Brideaux (1971), middle to late Albian (because of taxonomic complexity in this genus, the reported range for these forms is somewhat in question);

Batioladinium jaegeri (Alberti) Brideaux 1975, early Valanginian to late Albian;

Genus A, Albian (Virgil D. Wiggins, Standard Oil Co. of California, oral commun., 1978).

Age: probably late Albian.

Sample 35 (257 m).--Seven species of dinoflagellates were recovered. Age diagnostic forms are:

Pseudoceratium expolitum Brideaux, 1971, middle to late Albian;

Gardodinium eisenacki Alberti, 1961, Hauterivian to late Albian.

Age: probably late Albian.

Sample 36 (260 m).--Thirty-six species of dinoflagellates and acritarchs were recovered. Age diagnostic forms are:

Cleistosphaeridium multispinosum, middle Albian to early Cenomanian;

Cyclonephelium sp. A of Brideaux (1971), middle to late Albian; 


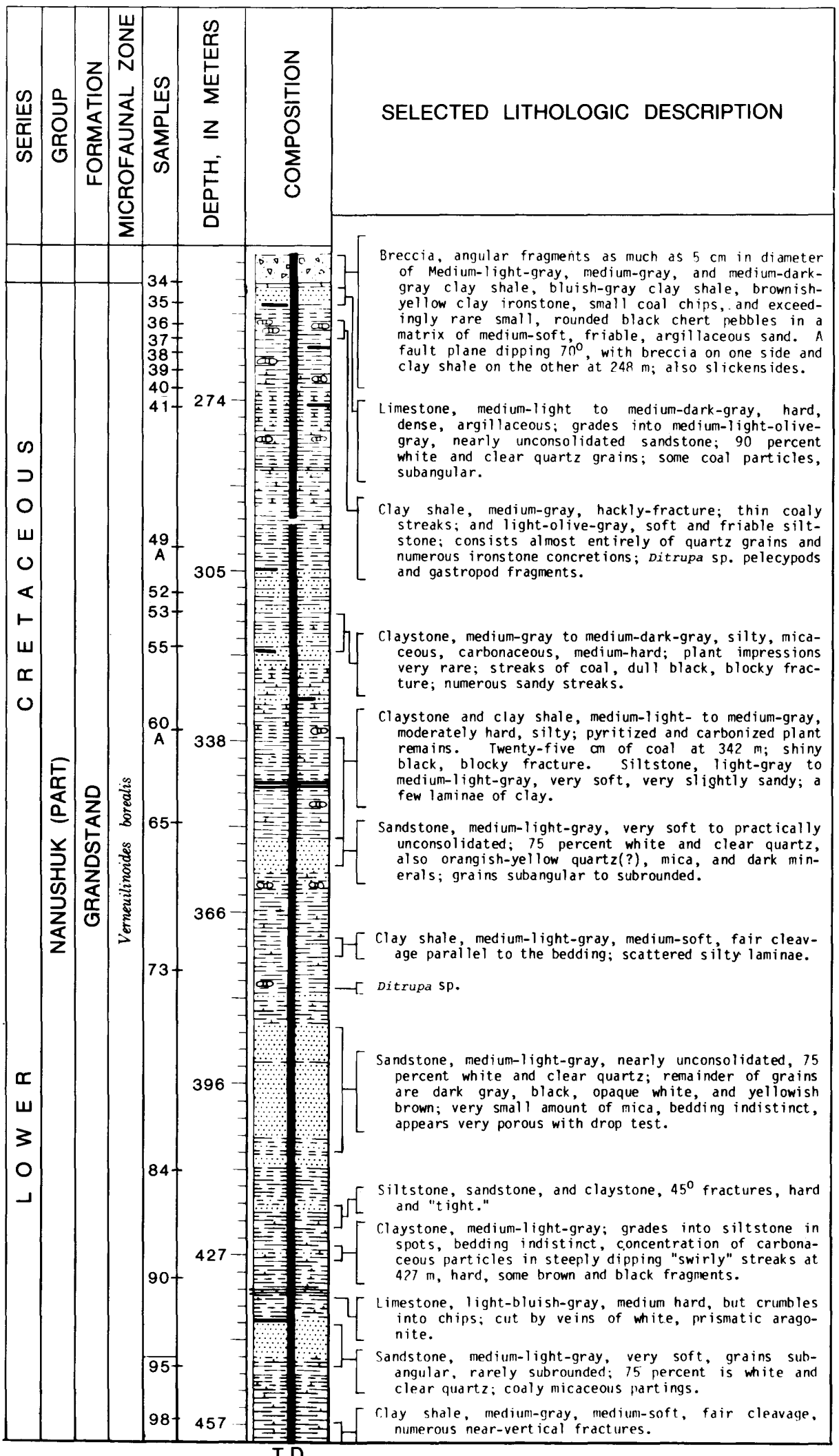

T.D.

Figure 46.--Columnar section of Grandstand Formation in Simpson core test 25 showing 1 ithologic descriptions for core and approximate sample depths; sample depths are within $3 \mathrm{~m}$ of where samples were taken, indicating tops of sampling intervals (modified from Robinson, 1964). 
Table 9.--Ranges of characteristic dinoflagellates and acritarchs from the Grandstand Formation of Simpson core test 25, North Slope, Alaska

[X indicates specimens present; $\mathrm{R}$ indicates specimens probably reworked; Brid. indicates Brideaux; McInt. indicates McIntyre; C.\&.E. indicates Cookson and Eisenack]

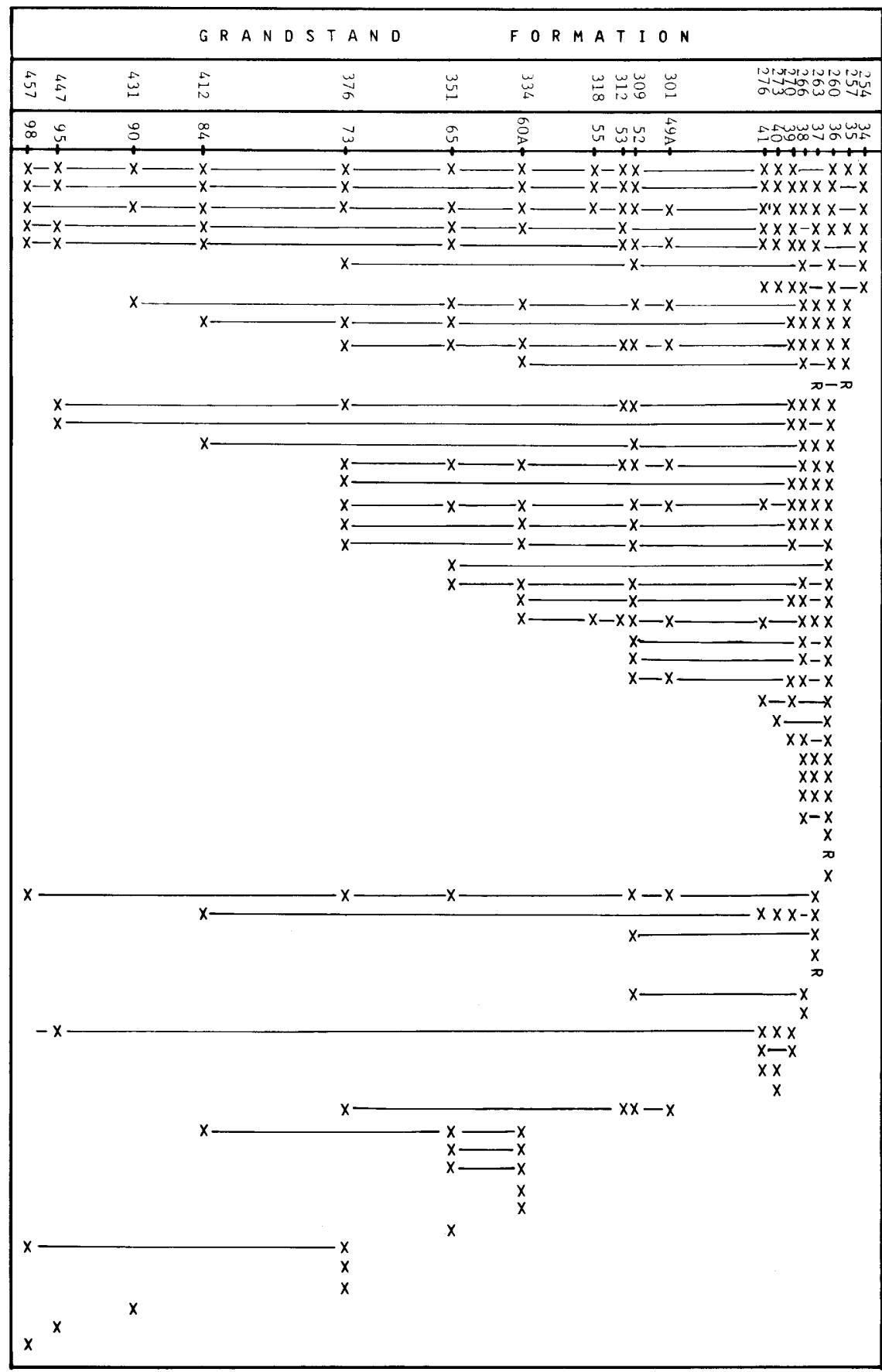

DEPTH (meters)

SAMPLE

01 igosphaer idium complex

Cleistosphaer idium mult ispinosum

Cyclonephelium sp. A of Brid. 1971

Gardodinium eisenacki $i$

Odontochitina operculata

Batioladinium jaegeri

Genus A

Pseudocer atium expol i tum

Spiniferites ramosus $r$ amosus

Luxadinium propatulum

Exochosphaeridium bifidum

Muderongia tetracantha

Palaeoperidinium cretaceum

?Achomosphaera sp.

Chl amydophorella nyei

Spinidinium vestitum

? Spongodinium extremum

Gonyaul acysta edwardsi

Cyclonephel ium ei senacki $i$

Odontochitina cf. 0 . operculata

Tanyosphaeridium sp. A of Brid. 1971

01 i gosphaer idium irregulare

Hystrichosphaeridium arundum

Apteodinium granulatum

Call aiosphaeridium asymmetricum

Carpodinium granulatum

01 igosphaer $i$ di um an thophorum

Pterodinium cornutum

Spiniferites scabrosus

Lithodinia stover $i$

Spiniferites cingulatus

Genus B

Hystrichosphaer idium stell atum

Kalyptea sp. A of Brid. 1971

Tenua sp. A

Tubotuberella rhombiformis

Clei stosphaeridium sp.

Cleis tosphaeridium polypes

Polygonomorphid acritarchs

Kalyptea monoceras

Hystrichokolpoma ferox of C.EE. 1974

Nelchinopsis kostromiensis

01 igosphaeridium sp. A

Spinifer $i$ tes $r$ amosus reticul atus

Canníngia colliveri

Cleistosphaeridium huguonioti

Balcattia cirrifera

Herkomorphid acritarchs

Deflandrea sp. 2 of McInt. 1974

Cyclonephel ium compactum

Muderongia sp. A

Luxadinium primulum

Scriniodinium sp.

Palaeostomacystis fragilis

Genus C

Deflandrea sp. A

Pediastrum sp.

Membranilarnacia leptoderma

Micrhystridium cf. M. piliferum

Tenua sp. B

Muder ongi a asymmetrica

Gardodinium eisenacki, Hauterivian to late Albian;

Batioladinium jaegeri, early Valanginian to late Albian;

Genus A, Albian;

Pseudoceratium expolitum, middle to late Albian;
Luxadinium propatulum Brideaux and McIntyre, 1975, middle Albian to early

Cenomanian;

Spinidinium vestitum Brideaux, 1971, middle Albian to early Cenomanian;

?Spongodinium extremum (Cookson and Eisenack) Lentin and Williams, 1976, 
Albian to Cenomanian;

Cyclonephelium eisenackii Davey, 1969, Albian;

Oligosphaeridium irregulare (Pocock) Davey and Williams, 1969, early to middle Albian of Alberta, Canada; range extended elsewhere;

Hystrichosphaeridium arundum Eisenack and Cookson, 1969, Aptian possibly into Cenomanian;

Apteodinium granulatum Eisenack, 1958, late Valanginian to Albian;

Carpodinium granulatum Cookson and Eisenack, 1962, emend. Leffingwel1 and Morgan, 1977, early Aptian to late Albian;

Pterodinium cornutum Cookson and Eisenack, 1962, early Berriasian to Albian;

Lithodinia stoveri (Millioud) Duxbury, 1977, Hauterivian to Albian;

Kalyptea sp. A of Brideaux (1971), Aptian to Albian.

Age: middle to late Albian.

Sample 37 (263 m).--Twenty-three species of dinoflagellates and acritarchs were recovered. Age diagnostic forms are:

Cleistosphaeridium multispinosum, middle Albian to early Cenomanian;

Cyclonephelium sp. A of Brideaux (1971), middle to late Albian;

Gardodinium eisenackii, Hauterivian to late Albian;

Pseudoceratium expolitum, middle to late Albian;

Luxadinium propatulum, middle Albian to early Cenomanian;

spinidinium vestitum, middle Albian to early Cenomanian;

?Spongodinium extremum, Albian to Cenomanian;

Cyclonephelium eisenackii, Albian;

Apteodinium granulatum, late Valanginian to Albian;

Cleistosphaeridium polypes Davey, 1969, Barremian to late Cenomanian;

Hystrichokolpoma ferox of Cookson and Eisenack (1974), Albian to Cenomanian.

Age: middle to late Albian.

Sample $38(266 \mathrm{~m})$.--Twenty-nine species of dinoflagellates were recovered. Age diagnostic forms are:

Cleistosphaeridium multispinosum, middle Albian to early Cenomanian;

Cyclonephelium sp. A of Brideaux (1971), middle to late Albian;

Batioladinium jaegeri, early Valanginian to late Albian;

Genus A, Albian;

Pseudoceratium expolitum, middle to late Albian;

Luxadinium propatulum, middle Albian to ear1y Cenomanian;

spinidinium vestitum, middle Albian to early Cenomanian;
?Spongodinium extremum, Albian to Cenomanian;

Cyclonephelium eisenackii, Albian;

oligosphaeridium irregulare, early to middle Albian of Alberta, Canada; range extended elsewhere;

Hystrichosphaeridium arundum, Aptian, possibly into Cenomanian;

Apteodinium granulatum, late Valanginian to Albian;

Carpodinium granulatum, early Aptian to late Albian;

Lithodinia stoveri, Hauterivian to Albian;

Kalyptea sp. A of Brideaux (1971), late Albian.

Age: late Albian.

Sample $39(270 \mathrm{~m})$.--Twenty-one species of dinoflagellates and acritarchs were recovered. Age diagnostic forms are:

Cleistosphaeridium multispinosum, middle Albian to early Cenomanian;

Cyclonephelium sp. A of Brideaux (1971); middle to late Albian;

Gardodinium eisenackii, Hauterivian to late Albian;

Genus A, Albian;

Luxadinium propatulum, middle Albian to early Cenomanian;

?Spongodinium extremum, Albian to Cenomanian;

Cyclonephelium eisenackii, Albian;

Hystrichosphaeridium arundum, Aptian, possibly into Cenomanian;

Pterodinium cornutum, early Berriasian to Albian;

Lithodinia stoveri, Hauterivian to Albian. Age: middle to late Albian.

Sample $40(273 \mathrm{~m}) .--E 1$ even species of dinoflagellates and acritarchs were recovered. Age diagnostic forms are:

Cleistosphaeridium multispinosum, middle Albian to early Cenomanian;

Cyclonephelium sp. A of Brideaux (1971), middle to late Albian;

Gardodinium eisenackii, Hauterivian to late Albian;

Genus A, Albian;

Balcattia cirrifera Cookson and Eisenack, 1974, Albian to Cenomanian.

Age: middle to late Albian.

Sample $41(273 \mathrm{~m})$.--Thirteen species of dinoflagellates and acritarchs were recovered. Age diagnostic forms are:

cleistosphaeridium multispinosum, middle Albian to early Cenomanian;

Cyclonephelium sp. A of Brideaux (1971), middle to late Albian;

Gardodinium eisenackii, Hauterivian to late Albian;

Genus A, Albian;

Apteodinium granulatum, late Valanginian to Albian; 
Pterodinium cornutum, early Berriasian to Albian;

Balcattia cirrifera, Albian to Cenomanian. Age: middle to late Albian.

Sample 49A (30I m).--Ten species of dinoflagellates were recovered. Age diagnostic forms are:

Cyclonephelium sp. A of Brideaux (1971), middle to late Albian;

Pseudoceratium expolitum, middle to late Albian;

Luxadinium propatulum, middle Albian to early Cenomanian;

Spinidinium vestitum, middle Albian to early Cenomanian;

Apteodinium granulatum, late Valanginian to Albian;

Cleistosphaeridium polypes, Barremian to late Cenomanian.

Age: middle to late Albian.

Sample 52 (309 m).--Twenty-three species of dinoflagellates were recovered. Age diagnostic forms are:

Cleistosphaeridium multispinosum, middle Albian to early Cenomanian;

Cyclonephelium sp. A of Brideaux (1971), middle to late Albian;

Batioladinium jaegeri, early Valanginian to late Albian;

Pseudoceratium expolitum, middle to late Albian;

Luxadinium propatulum, middle Albian to early Cenomanian;

spinidinium vestitum, middle Albian to early Cenomanian;

Cyclonephelium eisenackii, Albian;

Oligosphaeridium irregulare, early to middle Albian of Alberta, Canada; range extended elsewhere;

Hystrichosphaeridium arundum, Aptian, possibly into Cenomanian;

Apteodinium granulatum, late Valanginian to Albian;

Carpodinium granulatum, early Aptian to late Albian;

Cleistosphaeridium polypes, Barremian to late Cenomanian.

Age: middle to late Albian.

Sample $53(312 \mathrm{~m})$.--Ten species of dinoflage1lates were recovered. Age diagnostic forms are:

Cleistosphaeridium multispinosum, middle Albian to early Cenomanian;

Cyclonephelium sp. A of Brideaux (1971), middle to late Albian;

Gardodinium eisenackii, Hauterivian to late Albian;

Luxadinium propatulum, middle Albian to early Cenomanian;

spinidinium vestitum, middle Albian to early Cenomanian;
Apteodinium granulatum, late Valanginian to Albian.

Age: middle to late Albian.

Sample 55 (318 m).--Four species of

dinoflagellates were recovered. Age diagnostic forms are:

Cleistosphaeridium multispinosum, middle Albian to early Cenomanian;

Cyclonephelium sp. A of Brideaux (1971), middle to late Albian;

Apteodinium granulatum, late Valanginian to Albian.

Age: middle to late Albian.

Sample $60 \mathrm{~A}(334 \mathrm{~m})$.--Nineteen species of dinoflagellates and acritarchs were recovered. Age diagnostic forms are:

Cleistosphaeridium multispinosum, middle Albian to early Cenomanian;

Cyclonephelium sp. A of Brideaux (1971), middle to late Albian;

Gardodinium eisenackii, Hauterivian to late Albian;

Pseudoceratium expolitum, middle to late Albian;

Luxadinium propatulum, middle Albian to early Cenomanian;

Luxadinium primulum Brideaux and McIntyre, 1975, middle Albian;

Spinidinium vestitum, middle Albian to early Cenomanian;

Cyclonephelium eisenackii, Albian;

Oligosphaeridium irregulare, early to middle Albian of Alberta, Canada; range extended elsewhere.

Hystrichosphaeridium arundum, Aptian possibly into Cenomanian;

Apteodinium granulatum, late Valanginian to Albian;

Cyclonephelium compactum Deflandre and Cookson, 1955, Albian to Santonian.

Age: middle to late Albian.

Sample 65 (351 m).--Sixteen species of dinoflagellates were recovered. Age diagnostic forms are:

Cyclonephelium sp. A of Brideaux (1971), middle to late Albian;

Gardodinium eisenackii, Hauterivian to late Albian;

Pseudoceratium expolitum, middle to late Albian;

Luxadinium propatulum, middle Albian to early Cenomanian;

Luxadinium primulum, middle Albian;

Spinidinium vestitum, middle Albian to early Cenomanian;

oligosphaeridium irregulare, early to middle Albian of Alberta, Canada; range extended elsewhere.

Cleistosphaeridium polypes, Barremian to late Cenomanian;

Cyclonephelium compactum, Albian to Santonian.

Age: middle to late Albian. 
Sample $73(376 \mathrm{~m})$.--Sixteen species of dinoflagellates and one species of colonial Chlorophyta, Pediastrum Meyen, 1829, were recovered. Pediastrum, if it is not a contaminant, would suggest the proximity of lacustrine environments. Age diagnostic forms are:

Cleistosphaeridium multispinosum, middle Albian to early Cenomanian;

Cyclonephelium sp. A of Brideaux (1971), middle to late Albian;

Batioladinium jaegeri, early Valanginian to late Albian;

Luxadinium propatulum, middle Albian to early Cenomanian;

Spinidinium vestitum, middle Albian to early Cenomanian;

sspongodinium extremum, Albian to Cenomanian;

Cyclonephelium eisenackii, Albian;

Cleistosphaeridium polypes, Barremian to late Albian.

Age: middle to late Albian.

Sample $84(412 \mathrm{~m}) .--N i n e$ species of dinoflagellates and acritarchs were recovered. Age diagnostic forms are:

Cleistosphaeridium multispinosum, middle Albian to early Cenomanian;

Cyclonephelium sp. A of Brideaux (1971), middle to late Albian;

Gardodinium eisenackii, Hauterivian to late Albian;

Cyclonephelium compactum, Albian to Santonian.

Age: probably middle to late Albian.

Sample 90 (431 m).--Four species of dinoflagellates and acritarchs were recovered. Age diagnostic forms are:

Cyclonephelium sp. A of Brideaux (1971), middle to late Albian;

Pseudoceratium expolitum, middle to late Albian;

Micrhystridium cf. M. piliferum Deflandre, 1937. Specimens called Micrhystridium cf. M. piliferum by Brideaux (1971) are restricted to the upper Albian of central Alberta, Canada. Brideaux's specimens are very similar to Simpson core test 25 specimens. Thus, a late Albian age is being applied here for these specimens.

Age: 1ate Albian.

Sample $95(447 \mathrm{~m})$.--Eight species of dinoflagellates were recovered. Age diagnostic forms are:

Cleistosphaeridium multispinosum, middle

Albian to early Cenomanian;

Gardodinium eisenackii, Hauterivian to late Albian.

Age: probably middle to late Albian.

Sample 98 (457 m).--Nine species of dinoflagellates were recovered. Age diagnostic forms are:
Cleistosphaeridium multispinosum, middle Albian to early Cenomanian;

Cyclonephelium sp. A of Brideaux (1971), middle to late Albian;

Gardodinium eisenackii, Hauterivian to late Albian;

Cleistosphaeridium polypes, Barremian to late Albian;

Muderongia asymmetrica Brideaux, 1977, Aptian to early Albian.

Age: possibly early to middle Albian. The reported upper range of $M$. asymmetrica (Brideaux and McIntyre, 1975; Brideaux, 1977) suggests that this sample could be as old as early Albian.

\section{COMPARISON WITH FORMATIONS IN THE CANADIAN ARCTIC}

The taxa present in Simpson core test 25 generally tend to suggest an age for the Grandstand Formation there as middle to late Albian. Based on comparison of dinoflagellate assemblages reported here and in Brideaux and McIntyre (1975), the Grandstand Formation in Simpson core test 25 may correlate, in part, with the Horton River Formation in the District of Mackenzie, Canada. Species held in common are:

1. Cleistosphaeridium multispinosum (Singh) Brideaux, 1971;

2. Palaeoperidinium cretaceum Pocock, 1962, ex Davey, 1970;

3. Batioladinium jaegeri (Alberti) Brideaux, 1975;

4. Cyclonephelium compactum Deflandre and Cookson, 1955;

5. Oligosphaeridium irregulare (Pocock) Davey and Williams, 1969;

6. Gardodinium eisenackii Alberti, 1961;

7. Kalyptea sp. A of Brideaux (1971);

8. Luxadinium primulum Brideaux and McIntyre, 1975.

\section{COMPARISON WITH FORMATIONS IN CENTRAL ALBERTA, CANADA}

Comparison with the work of Brideaux (1971) makes possible a general correlation of the Grandstand Formation of Simpson core test 25 with the Peace River and Lower Shaftsbury Formations of west-central Alberta, and with the Joli Fou, Viking, and Pelikan Formations, and "Upper Shale Unit" of south-central Alberta. Species held in common are:

1. Palaeoperidinium cretaceum Pocock, 1962, ex Davey, 1970;

2. Oligosphaeridium irregulare (Pocock) Davey and Williams, 1969;

3. Odontochitina operculata (0. Wetze1) Deflandre and Cookson, 1955;

4. Canningia colliveri Cookson and Eisenack, 1960;

5. Cleistosphaeridium multispinosum Brideaux, 1971; 
6. Oligosphaeridium anthophorum (Cookson and Eisenack) Davey, 1969;

7. Pseudoceratium expolitum Brideaux, 1971;

8. Palaeostomocystis fragilis Cookson and Eisenack, 1962;

9. Batioladinium jaegeri (Alberti) Brideaux, 1975;

10. Spinidinium vestitum Brideaux, 1971;

11. Oligosphaeridium complex (White) Davey and Williams, 1966;

12. Spiniferites ramosus subsp. ramosus (Ehrenberg) Loeblich and Loeblich, 1966 ;

13. Cyclonephelium eisenackii Davey, 1969;

14. Chlamydophorella nyei Cookson and Eisenack, 1958;

15. Kalyptea sp. A of Brideaux, 1971;

16. Micrhystridium $c f$. M. piliferum Deflandre, 1937 of Brideaux (1971);

17. Luxadinium propatulum Brideaux and McIntyre, 1975;

18. Cyclonephelium sp. A of Brideaux, 1971.

The concurrent ranges of these taxa in both areas would tend to support the correlation of the Grandstand Formation in Simpson core test 25 with the above-mentioned formations in central Alberta, and would suggest a middle or late Albian age for the Grandstand Formation. Many of these same taxa are also found in assemblages from the Loon River, Peace River, and Shaftsbury Formations of the Peace River area, northern Alberta (Singh, 1971), suggesting a middle to late Albian age for the Grandstand Formation of Simpson core test 25 .

\section{COMPARISON WITH AUSTRALIAN TAXA}

The Perth Basin, western Australia, dinoflagellate assemblages collected from the Albian interval of the Moora bore $(26-52 \mathrm{~m}$ ) and the Osborne Formation of Albian to Cenomanian Age of the Balcatta No. 1 and No. 2 bores (Cookson and Eisenack, 1974) show some similarities to the Grandstand assemblages reported here. Balcattia cirrifera Cookson and Eisenack, 1974, from the Osborne Formation of the Balcatta No. 1 bore has been rarely reported elsewhere, but it occurs in two of the Grandstand Formation samples (samples 40 and 41). ?Spongodinium extremum (Cookson and Eisenack) Lentin and Williams, 1977, also from the Osborne Formation of the Balcatta No. 1 bore, occurs in five of the Grandstand Formation samples (samples 36, $37,38,39$, and 73). Cyclonephelium eisenackii
Davey, 1969, identified by Cookson and Eisenack (1974) as Aptea polymorpha Eisenack, 1958, is reported by them only from the Albian interval of the Moora bore. C. eisenackii occurs in samples $36,37,38,39,52,60 \mathrm{~A}$, and 73 from the Grandstand. A form identified by Cookson and Eisenack (1974) as Hystrichokolpoma ferox Deflandre, 1937, from the Albian of the Moora bore occurs in sample 37 from the Grandstand. These similarities in occurrences support the Albian Age determined for the Grandstand and suggest possible correlations with stratigraphic strata as distant as Australia.

\section{SUMMARY AND CONCLUSIONS}

Diverse dinoflagellate and acritarch assemblages are present in the Grandstand Formation of Simpson core test 25, North Slope, Alaska. Fifty-nine taxa of dinoflagellates, the stratigraphic ranges for these taxa, and two general acritarch groupings have been identified and illustrated. Preservation of the specimens is good.

A middle or late Albian age is suggested for the Grandstand Formation samples reported, based primarily on comparison with similar published Canadian assemblages; supporting evidence exists from Australian assemblages. Comparison with Canadian assemblages suggests that the Grandstand Formation in Simpson core test 25 correlates with at least parts of the Peace River and Lower Shaftsbury Formations of west-central Alberta; the Joli Fou, Viking, and Pelican Formations, and "Upper Shale Unit" of south-central Alberta; and the Loon River, Peace River, and Shaftsbury Formations of the Peace River area, northern Alberta.

Moderate species diversities (between 20 and 40 species) suggest normal marine conditions for some of the samples studied (samples 36 , $37,38,39$, and 52). Such diversity is not nearly as high as in samples observed by the authors from normal marine Upper Cretaceous Atlantic and Gulf Coast samples (40 to 60 species); and, therefore, it is suggested that these assemblages represent very nearshore conditions. Some samples reported here having less than 10 or 15 species would seem to represent abnormal marine conditions, possibly estuarine or lagoonal (samples 34, 35, 40, 41, $49 \mathrm{~A}, 53,55,84,90,95$, and 98). This is in keeping with the general interpretations of the kinds of depositional environments that existed for the Grandstand Formation (Thomas S. Ahlbrandt, oral commun., 1978). 


\section{PLATE 13}

Figure 1. Cyclonephelium eisenackii Davey 1969, length $86 \mu \mathrm{m}$.

2,6. Cyclonephelium sp. A of Brideaux (1971), width range 64-80 $\mu \mathrm{m}$.

3. Canningia colliveri Cookson and Eisenack, 1960, length $68 \mu \mathrm{m}$.

4,8. Cyclonephelium compactum Deflandre and Cookson, 1955.

4. Operculum, length $6 \mu \mathrm{m}$.

8. Specimen lacking operculum, length $102 \mu \mathrm{m}$.

5. Tenua sp. A, length $68 \mu \mathrm{m}$.

7. Tenua sp. B., length $36 \mu \mathrm{m}$.

9,10 . Genus $B$, width range 84-94 $\mu \mathrm{m}$.

11,14,15. Gonyaulacysta edwardsi Cookson and Eisenack, 1958.

11. Operculum, length $58 \mu \mathrm{m}$.

14. Lateral view, length $134 \mu \mathrm{m}$.

15. Dorsal view, width $122 \mu \mathrm{m}$.

13. Apteodinium granulatum Eisenack, 1958, dorsal view, $68 \mu \mathrm{m}$.

12,16. ?Spongodinium extremum (Cookson and Eisenack) Lentin and Williams, 1976.

12. Operculum, length $32 \mu \mathrm{m}$.

16. Ventral view, length $92 \mu \mathrm{m}$. 

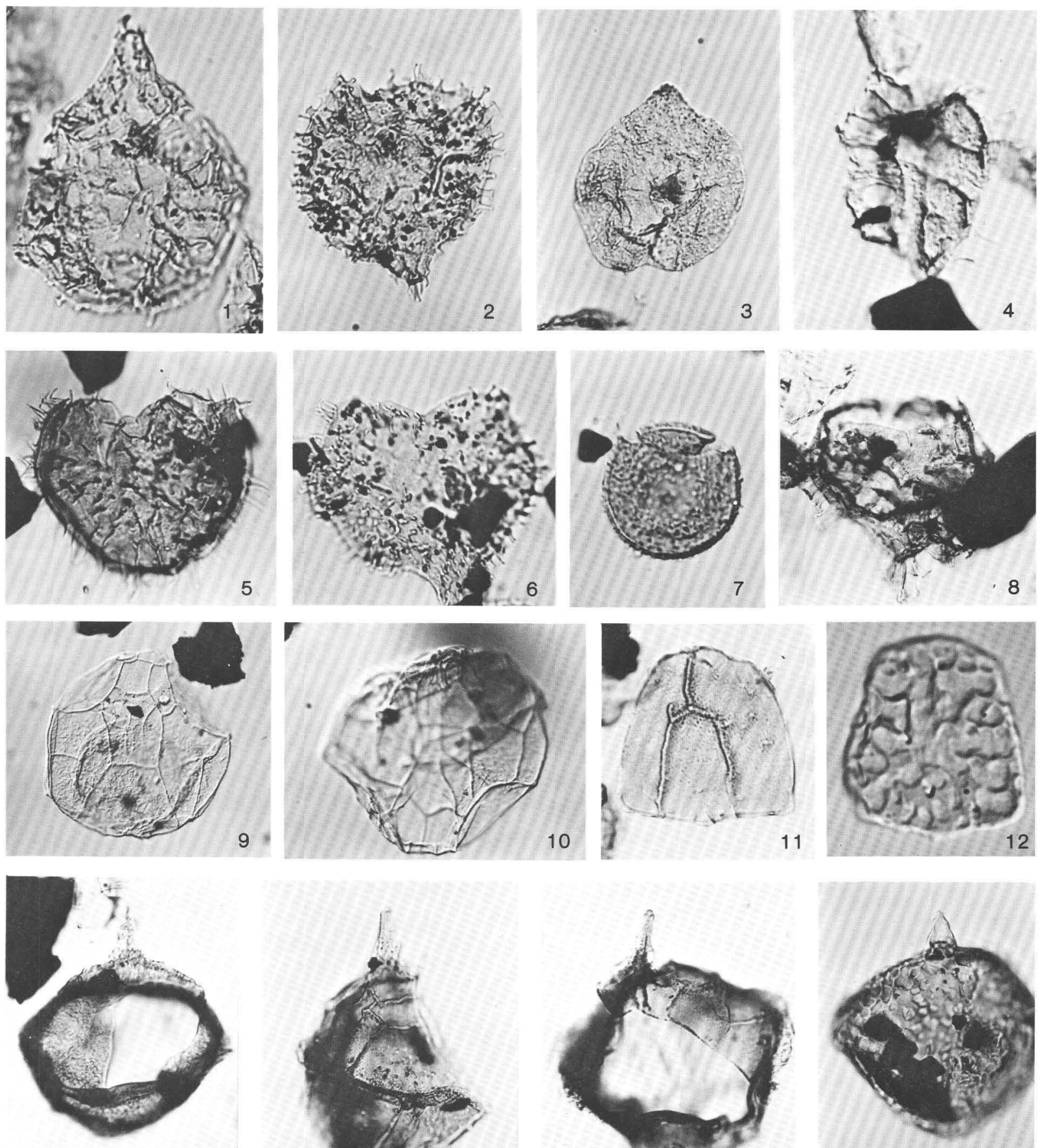

$$
+13
$$
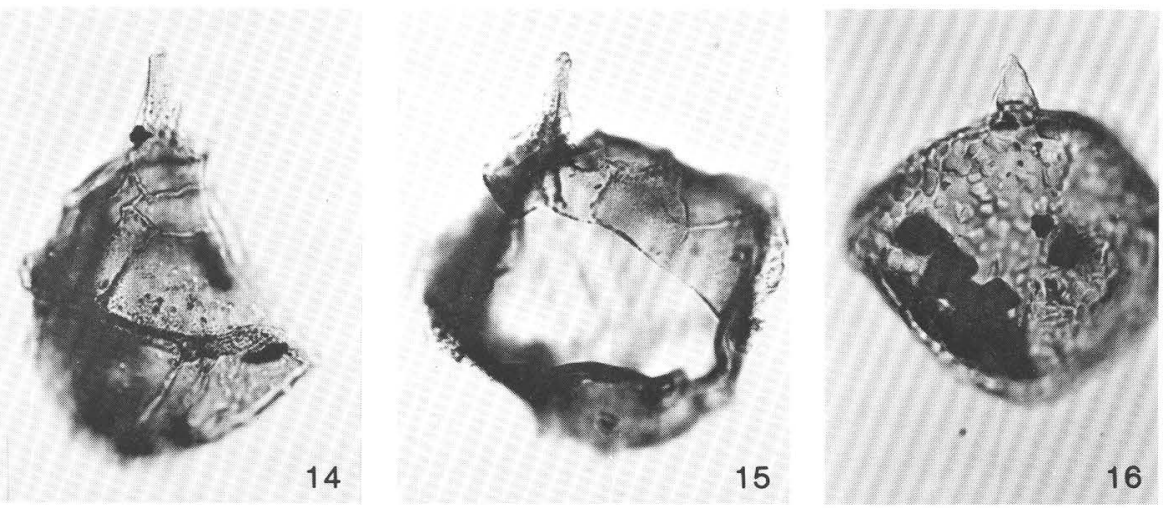
Figures 1,2. Genus A.

1. Ventral view, length $120 \mu \mathrm{m}$.

2. Fragment showing cingulum, width $74 \mu \mathrm{m}$.

3,4. Carpodinium granulatum Cookson and Eisenack, 1962, length range $72-74 \mu \mathrm{m}$.

5. Tubotuberella rhombiformis Vozzhennikova, 1967, length $124 \mu \mathrm{m}$.

6,7. Lithodinia stoveri (Millioud) Duxbury, 1977, length range 52-54 $\mu \mathrm{m}$.

8,9,13. Spiniferites cingulatus (0. Wetzel) Serjeant, 1970, length range of main body 40-50 $\mu \mathrm{m}$.

10,14. Pterodinium cornutum Cookson and Eisenack, 1962, 1ength range of main body $60-62 \mu \mathrm{m}$.

11,12. Achomosphaera sp., width range of main body $62-70 \mu \mathrm{m}$.

15. Spiniferites ramosus subsp. ramosus (Ehrenberg) Loeblich and Loeblich, 1966, length of main body $44 \mu \mathrm{m}$.

16,17. Spiniferites scabrosus (Clarke and Verdier) Lentin and Williams, 1975, width range of main body 42-54 $\mu \mathrm{m}$. 

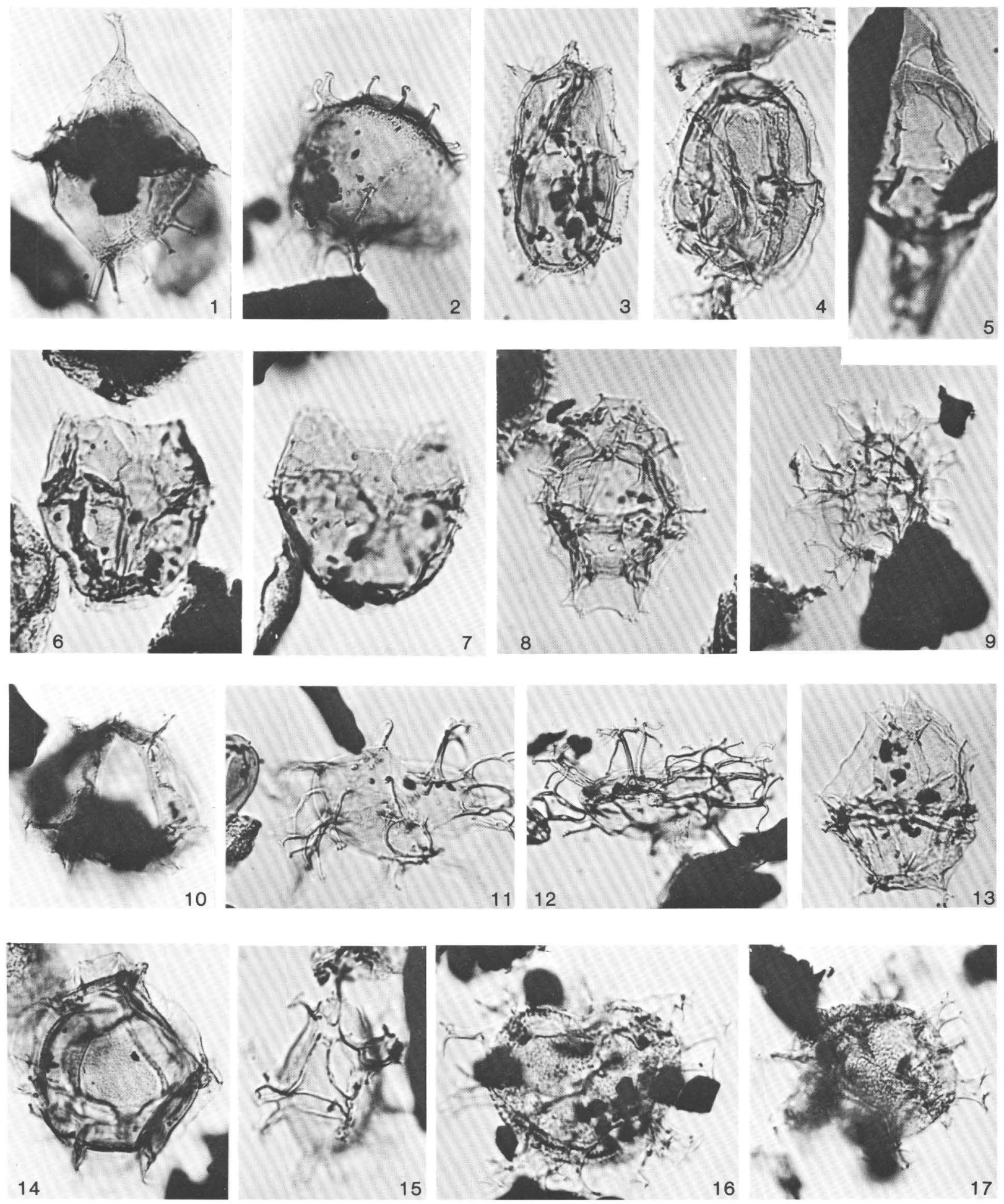
PLATE 15

Figure 1. Spiniferites ramosus subsp. reticulatus (Davey and Williams) Lentin and Williams, 1973, length $46 \mu \mathrm{m}$.

2,3,4. Pseudoceratium expolitum Brideaux, 1971.

2,4. Length range without operculum 62-88 $\mu \mathrm{m}$.

3. Length $100 \mu \mathrm{m}$.

5,9. Odontochitina operculata (0. Wetze1) Deflandre and Cookson, 1955.

5. Length of operculum $176 \mu \mathrm{m}$.

9. Length of specimen without operculum $146 \mu \mathrm{m}$.

6. Muderongia asymmetrica Brideaux, 1977, length $66 \mu \mathrm{m}$.

7. Muderongia tetracantha (Gocht) Alberti, 1961, length $98 \mu \mathrm{m}$.

8. Muderongia sp. A, length $144 \mu \mathrm{m}$.

10. Odontochitina cf. O. operculata (O. Wetze1) Deflandre and Cookson, 1955, 1ength 148 $\mu \mathrm{m}$.

11,15,16. Balcattia cirrifera Cookson and Eisenack, 1974.

11. Length of main body $76 \mu \mathrm{m}$.

15,16. Width of operculum main body $70 \mu \mathrm{m}$.

12. Genus $\mathrm{C}$, length $116 \mu \mathrm{m}$.

13,14. Callaiosphaeridium asymmetricum (Deflandre and Courteville) Davey and Williams, 1966.

13. Width of main body $60 \mu \mathrm{m}$.

14. Width of main body $50 \mu \mathrm{m}$. 

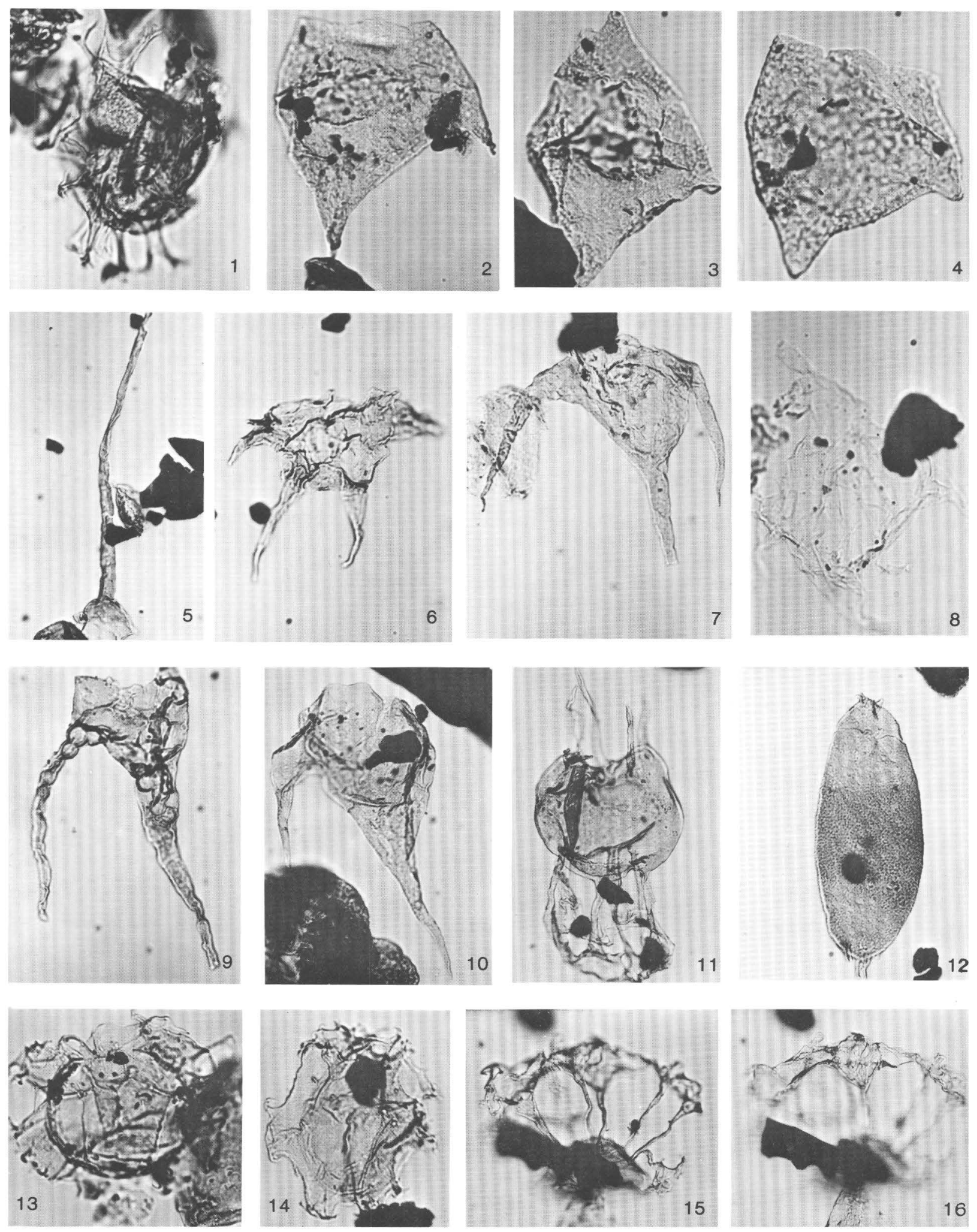


\section{PLATE 16}

Figure 1. Exochosphaeridium bifidum (Clarke and Verdier) Clarke and others, 1968, 1ength of main body $64 \mu \mathrm{m}$.

2. Hystrichokolpoma ferox of Cookson and Eisenack (1974), length of main body $44 \mu \mathrm{m}$.

3. Membranilarnacia leptoderma (Cookson and Eisenack) Eisenack, 1963, overall width 37 $\mu \mathrm{m}$.

4. Oligosphaeridium sp. A, length of main body $34 \mu \mathrm{m}$.

5. Hystrichosphaeridium stellatum Maier, 1959, length of main body $40 \mu \mathrm{m}$.

6,7. Oligosphaeridium anthophorum (Cookson and Eisenack) Davey, 1969.

6. Length of main body $54 \mu \mathrm{m}$.

7. Width of operculum $34 \mu \mathrm{m}$.

8. Hystrichosphaeridium arundum Eisenack and Cookson, 1960, length of main body $56 \mu \mathrm{m}$.

9. Tanyosphaeridium sp. A, length $40 \mu \mathrm{m}$.

10. Oligosphaeridium irregulare (Pocock) Davey and Williams, 1969 , length of main body $40 \mu \mathrm{m}$.

11,12. Oligosphaeridium complex (White) Davey and Williams, 1966.

11. Length of main body $42 \mu \mathrm{m}$.

12. Length of main body $72 \mu \mathrm{m}$.

13. Cleistosphaeridium multispinosum (Singh) Brideaux, 1971, length of main body $46 \mu \mathrm{m}$.

14. Cleistosphaeridium polypes (Cookson and Eisenack) Davey, 1969, length of main body $44 \mu \mathrm{m}$.

15. Cleistosphaeridium huguonioti (Valensi) Davey, 1969, length of main body $36 \mu \mathrm{m}$. 16,17,18. Chlamydophorella nyei Cookson and Eisenack, 1958.

16. Length $46 \mu \mathrm{m}$.

17. Length $56 \mu \mathrm{m}$.

18. Length $52 \mu \mathrm{m}$.

19. Cleistosphaeridium sp., length of main body $52 \mu \mathrm{m}$.

20,21. Gardodinium eisenackii (Alberti) Lentin and Williams, 1977.

20. Length $66 \mu \mathrm{m}$.

21. Length $78 \mu \mathrm{m}$. 

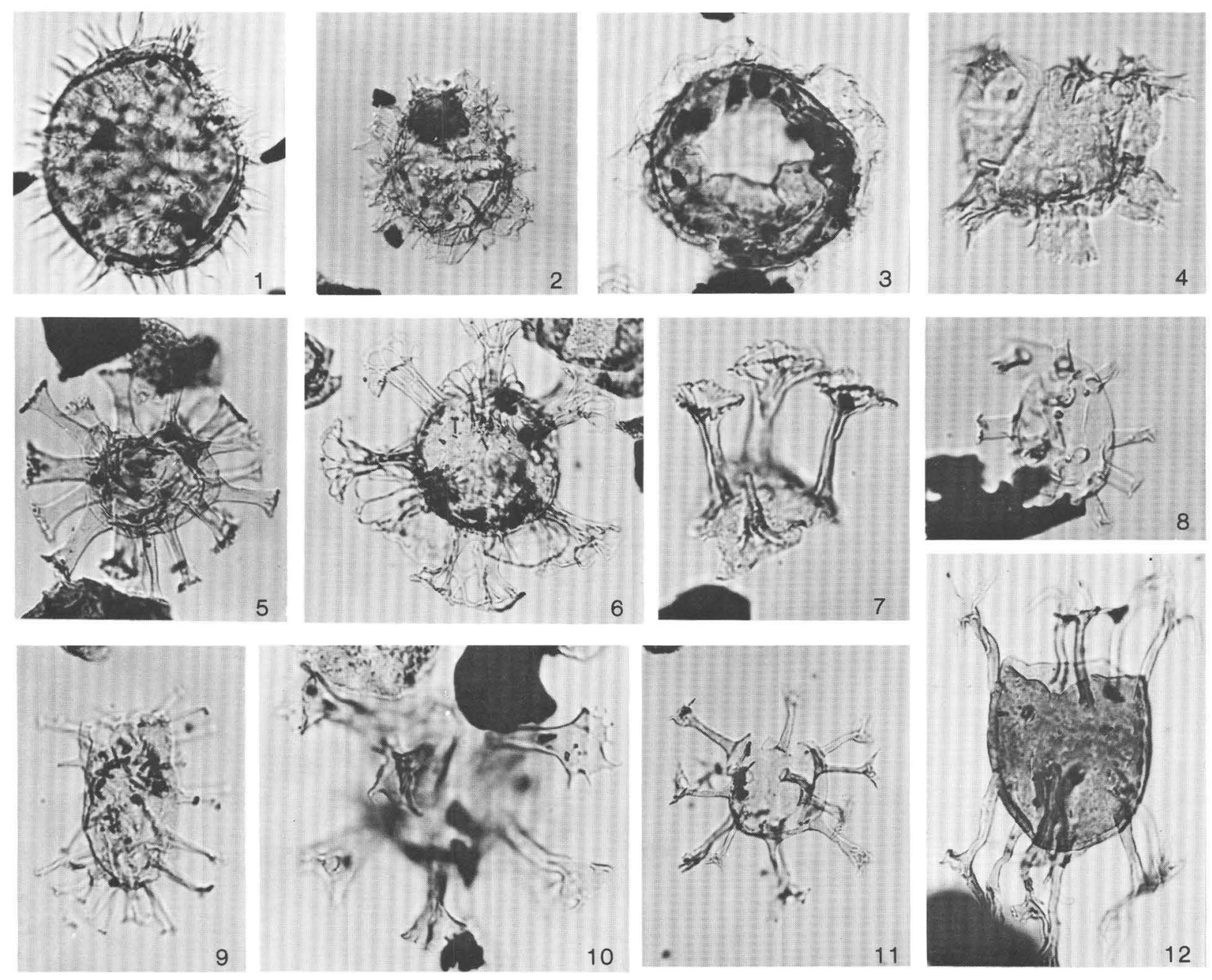

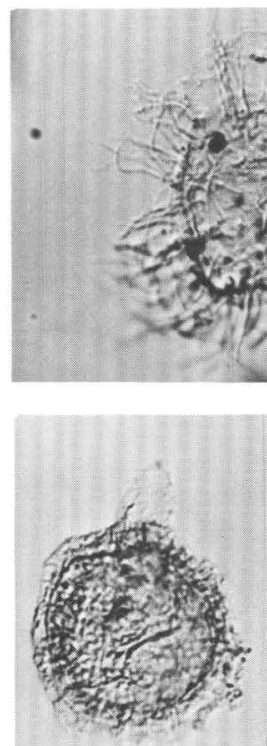

17

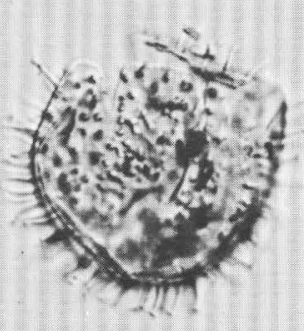

14
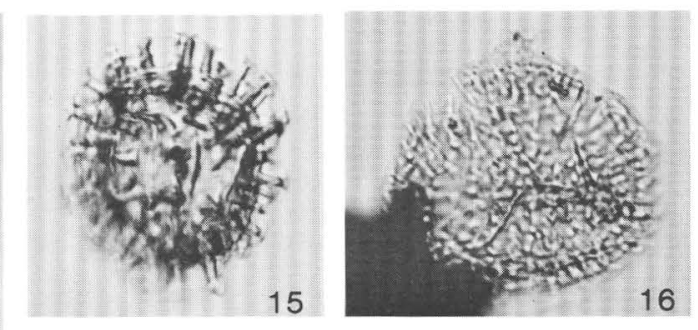

13

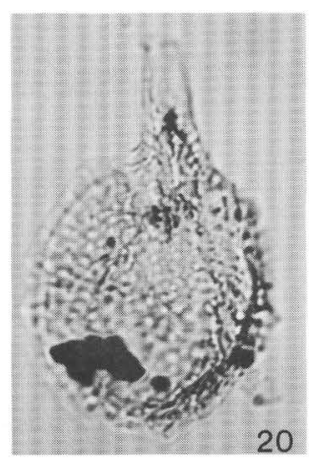




\section{PLATE 17}

Figures 1,2. Batioladinium jaegeri Brideaux, 1975.

1. Length $148 \mu \mathrm{m}$.

2. Length $116 \mu \mathrm{m}$.

3,4. Kalyptea monoceras Cookson and Eisenack, 1960.

3. Length $60 \mu \mathrm{m}$.

4. Length $94 \mu \mathrm{m}$.

5. Kalyptea sp. A of Brideaux (1971), length of main body $50 \mu \mathrm{m}$.

6,7. Deflandrea sp. 2 of McIntyre (1974).

6. Length $54 \mu \mathrm{m}$.

7. Length $50 \mu \mathrm{m}$.

8. Deflandrea sp. A, length $58 \mu \mathrm{m}$.

9,10. Luxadinium propatulum Brideaux and McIntyre, 1975.

9. Width of operculum $56 \mu \mathrm{m}$.

10. Length $80 \mu \mathrm{m}$.

11. Palaeoperidinium cretaceum Pocock ex Davey, 1970, length $88 \mu \mathrm{m}$.

12,13. Spinidinium vestitum Brideaux, 1971.

12. Length $68 \mu \mathrm{m}$.

13. Length $64 \mu \mathrm{m}$.

14. Luxadinium primulum Brideaux and McIntyre, 1975, length $58 \mu \mathrm{m}$.

15. Nelchinopsis kostromiensis (Vozzhennikova) Wiggins, 1972, length $60 \mu \mathrm{m}$.

16. Pediastrum sp., diameter $48 \mu \mathrm{m}$.

17. Veryhachium europaeum of Brideaux (1971), a polygonomorphid acritarch, diagonal length $54 \mu \mathrm{m}$.

18. Veryhachium sp. 2, maximum diameter $20 \mu \mathrm{m}$.

19. Palaeostomacystis fragilis Cookson and Eisenack, 1962, width $66 \mu \mathrm{m}$.

20. Scriniodinium sp., length $50 \mu \mathrm{m}$.

21. Micrhystridium cf. M. piliferum of Brideaux (1971), diameter main body $32 \mu \mathrm{m}$.

22,23. Veryhachium reductum Deunff emend. De Jekhowsky, 1961.

22. Length of side of main body $20 \mu \mathrm{m}$.

23. Length of side of main body $80 \mu \mathrm{m}$.

24. ?Cymatiosphaera sp., a herkomorphid acritarch, diameter $33 \mu \mathrm{m}$. 

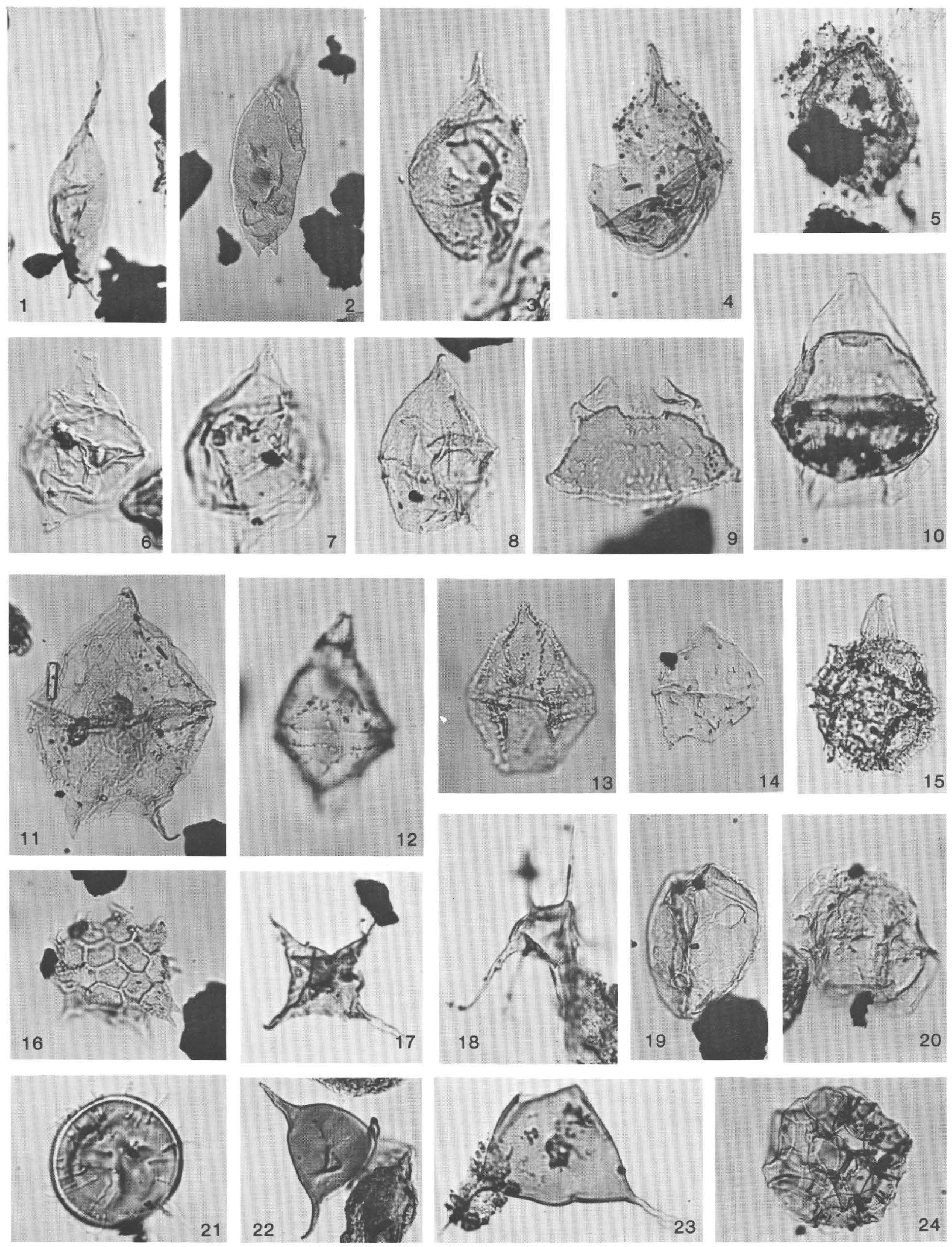



\section{CRETACEOUS FORAMINIFERS FROM THE NORTH SLOPE OF ALASKA}

By William V. Sliter

The data reported here represent a reexamination of foraminiferal assemblages recovered from the Albian to Cenomanian interval of Umiat test well 11 and new occurrences from surface sections collected during the 1977 summer field season (fig. 47; see Ahlbrandt and others, this volume). This study is part of a continuing project designed to better correlate foraminiferal and palynological data and to improve environmental interpretations.

\section{UMIAT}

Foraminifers from Umiat test well 11 previously were described by Bergquist (1966). Reexamination of selected slides from both cores and ditch samples confirms the original taxonomic interpretations. Foraminiferal occurrence in cores from the upper part of the Torok Formation and the Nanushuk Group are shown in figure 48. The fauna consists of 21 species of which 8 are calcareous. Characteristic foraminiferal species are shown in plate 18 . In general, occurrences are sporadic, diversity is low, and preservation is poor to moderate. Despite these deficiencies, the species distributions are adequate for age determinations and correlations. Taxonomic identifications used herein follow those of Tappan (1962)

The Ninuluk Formation is assigned to a 36$m$ interval of massive, argillaceous sandstone with dark-gray siltstone and claystone at the base. Foraminifers are restricted to the lower siltstone and argillaceous sandstone in cores 40 and 41 and consist of Trochammina rutherfordi Stelck and Wall and Saccammina lathrami Tappan. The abundance and taxonomic characteristics of T. rutherfordi indicate a Cenomanian Age for this interval. Cores 35 to 39 from the massive sandstone are barren of foraminifers. Megafossils recovered from the Ninuluk Formation are Cenomanian in age (Detterman, 1956; Jones and Gryc, 1960; Imlay, 1961). On the basis of these occurrences, the Ninuluk Formation is correlated with the Belle Fourche Shale of the Western Interior of the United States and the Dunvegan Formation of British Columbia, both considered to be Cenomanian in age. Deposi- tional environments represent marginal-marine facies at the base of the formation that grade upward into brackish-water or nonmarine facies at the top.

The Killik Tongue of the Chandler Formation is represented by about $79 \mathrm{~m}$ of interbedded argillaceous sandstone, siltstone, and claystone that has local carbonaceous streaks and coaly material. Fish debris is found rarely in the sequence, and foraminifers are limited to the long-ranging Saccammina lathrami Tappan in core 48. The remaining cores from this unit, cores 42 to 47, 49, and 50, are barren of foraminifers. Although no foraminifers were recovered from samples at the type area of the Killik Tongue along the Killik River, exposures of the Killik to the north near Umiat contain late Albian species such as Verneuilinoides borealis Tappan, Haplophragmoides topagorukensis Tappan, Psamminopelta bowsheri Tappan, and Gaudryina canadensis Cushman (Detterman, 1956; Bergquist, 1966). These occurrences probably represent marine interfingers of the adjacent Grandstand Formation. Consequently, the regional age relationships of the Killik Tongue, especially those at the upper boundary with the Ninuluk Formation, remain undecided. It is entirely possible that the Albian-Cenomanian boundary lies within the Killik Tongue and that Cenomanian strata extend into the overlying Ninuluk Formation. The Killik Tongue is typified by delta-platform deposits containing rare occurrences of brackish-water and freshwater pelecypods and occasional interbeds of marginalmarine deposits that contain fish debris and foraminifers.

A section of nearly $200 \mathrm{~m}$ of sandstone, claystone, and shale is placed within the Grandstand Formation. Moderately diverse and continuously occurring foraminifers of Albian Age were recovered throughout the section beginning with a ditch sample at 740 to $742 \mathrm{~m}$ in dark-gray siltstone, some $2 \mathrm{~m}$ below the contact with the overlying Killik Tongue. This uppermost assemblage includes Verneuilinoides borealis Tappan, Miliammina awunensis Tappan, Gaudryina canadensis Cushman, Psamminopelta subcircularis Tappan, and Haplophragmoides 


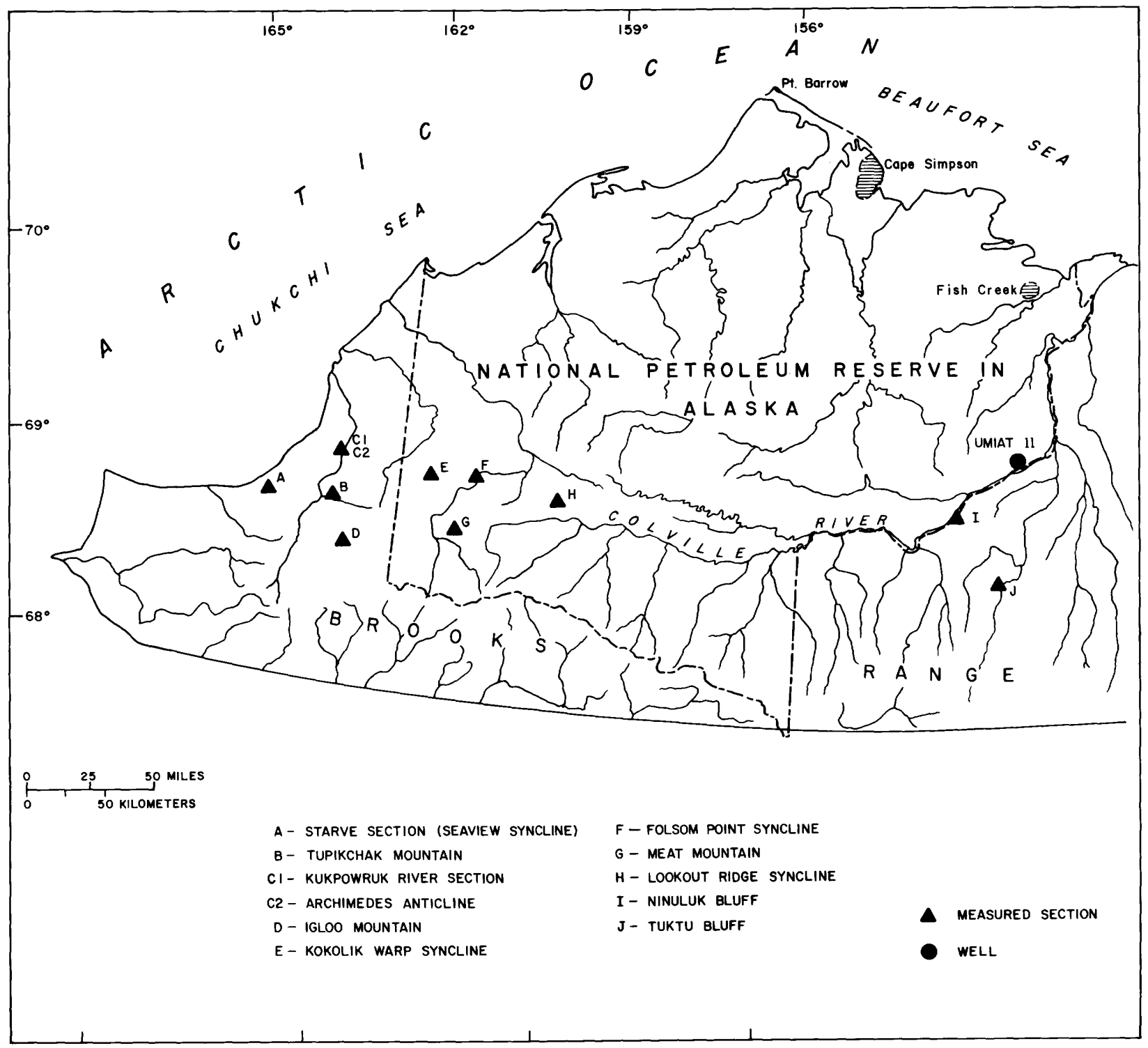

Figure 47.--Index map of northern Alaska showing location of 1977 NPRA (National Petroleum Reserve in Alaska) field collections and Umiat test well 11.

topagorukensis Tappan. Older assemblages within the Grandstand Formation from cores 55, 56, and 59 include species such as Gavelinella stictata (Tappan), Ammobaculites wenonahae Tappan, Globorotalites alaskensis Tappan, and Miliammina manitobensis Wickenden. Cores 52, $53,57,58$, and 60 are barren of foraminifers. The occurrence of the ammonite Cleoniceras in basal beds of the Grandstand Formation suggests a middle Albian age (Imlay, 1961, p. 12), whereas the upper beds are inferred by stratigraphic relationships to be late Albian in age. Depositional environments within the Grandstand Formation range from neritic to bathyalprodelta to delta-front deposits, with evidence of shoaling near the upper boundary.
Albian foraminifers continue downward into the Torok Formation represented by some $70 \mathrm{~m}$ of shale, siltstone, and dark-gray claystone. The highest-diversity assemblage was recovered from core 61 at the base of the test well. In addition to the Grandstand assemblages, the fauna includes Conorboides umiatensis (Tappan), Globulina canadensis Mellon and Wall, and Saracenaria projectura Stelck and Wall among others. Megafossils in the upper third of the Torok Formation, such as the ammonites Gastroplites, Paragastroplites, and Cleoniceras, indicate a middle Albian age (Imlay, 1961). Outer neritic to bathyal-prodelta environments are indicated by the foraminiferal assemblage.

Foraminifers from the upper part of the 


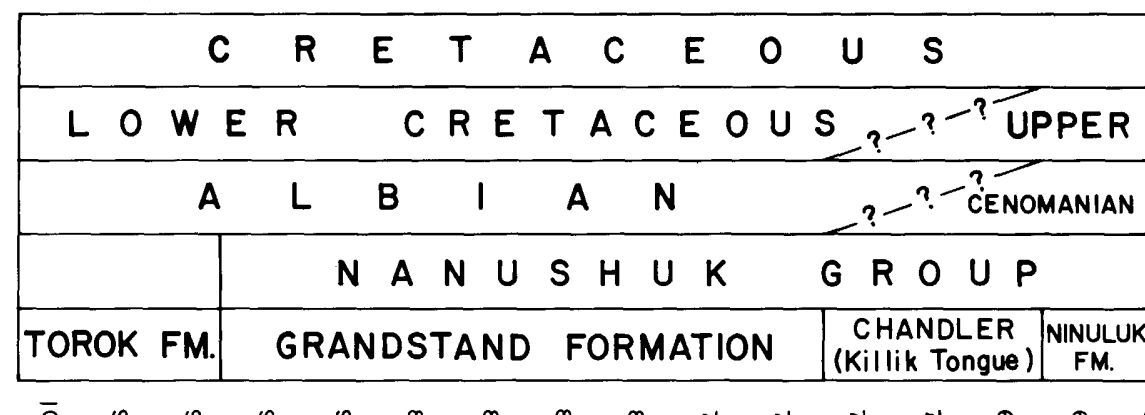

SYSTEM

\section{SERIES}

STAGE

GROUP

\section{FORMATION}

\section{DEPTH (METERS)}

\section{CORE}

\section{LITHOLOGY}

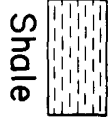

$\frac{1}{2}$

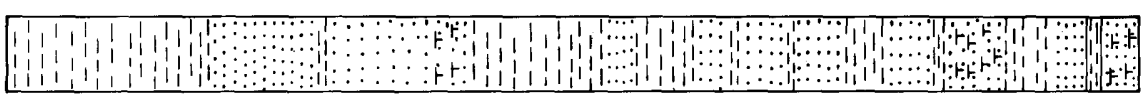

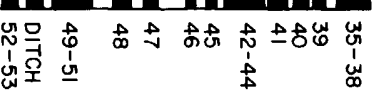

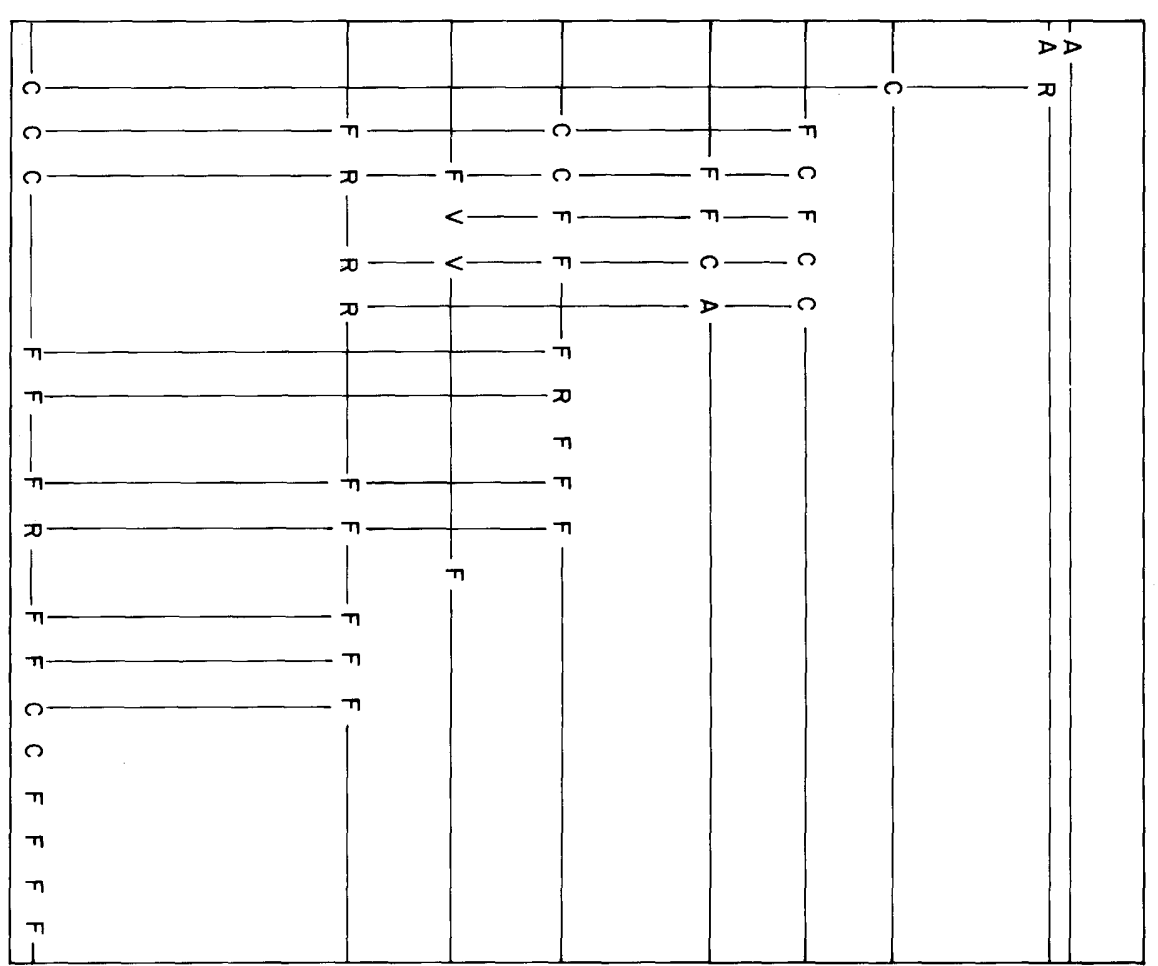

Trochammina rutherfordi Saccammina lathrami

STELCK AND WALL Haplophragmoides topagor TAPPAN

Verneuilinoides boreolis TAPPAN

Gaudryina canadensis CUSHMAN

Miliammina awunensis TAPPAN

Psamminopelta subcircularis TAPPAN

Gavelinello stictata (TAPPAN)

Quadrimorphina ruckerae (TAPPAN)

Lenticulina macrodisca (REUSS)

Ammobaculites wenonahoe TAPPAN

Praebulimina nannina (TAPPAN)

Gaudryinella irregularis TAPPAN

Bathysiphon vitta NAUSS

Globorotalites alaskensis TAPPAN

Miliammina manitobensis WICKENDEN

Bathysiphon brosgei TAPPAN

Conorboides umiatensis (TAPPAN)

Globulina canadensis MELLON and WALL

Marginulina planiuscula (REUSS)

Saracenaria projectura STELCK and WALL 
Torok Formation and Nanushuk Group of Umiat test we11 11 provide correlation with other reference sections in the North American Arctic area. Most notable are the Arctic Red Formation of the northern Yukon and the Christopher Formation of the Sverdrup Basin. The Arctic Red Formation is dated as early to late Albian by Mountjoy and Chamney (1969). Foraminifers include Verneuilinoides borealis Tappan, Pseudobolivina rayi (Tappan), Gavelinella stictata (Tappan), Ammobaculites fragmentarius Cushman, and Globulina canadensis Mellon and Wall among others, which provide good correlation with the Umiat 11 section. In the Sverdrup Basin, foraminifers from the upper unit of the Christopher Formation on Ammund and Ellef Ringnes Islands correlate closely with those of the upper part of the Torok and Grandstand Formations of Umiat test well 11 (Sliter, in press). These Canadian assemblages include foraminifers such as Verneuilinoides borealis Tappan, Trochammina rainwateri Cushman and Applin, Psamminopelta bowsheri Tappan, Miliammina ischnia Tappan, Ammobaculites fragmentarius Cushman, and Pseudobolivina rayi (Tappan). Megafossils collected along with the foraminiferal assemblages about $30 \mathrm{~m}$ above the base of the upper unit of the Christopher Formation provide an early middle Albian age (J. Jeletzky, oral commun., 1974; Geological Survey of Canada 1oc. C-26600). The marine shales of the Christopher Formation grade upward into marginalmarine and delta-platform deposits of the overlying Hassel Formation. These deposits consist of glauconitic sandstone with low-angle cross-strata, coarse-grained sandstone with high-angle cross-strata, and fine-grained sandstone and siltstone with thin coal beds. The age of the Hassel Formation, based on microflora, is latest Albian and early Cenomanian (Hopkins and Balkwil1, 1973). The Hassel Formation thus corresponds closely in both lithology and age to the Killik Tongue of the Chandler Formation in Umiat test we11 11.

\section{SURFACE SECTIONS}

Foraminifers collected during the 1977 summer field season from surface sections along the North Slope of Alaska are included as they provide new age and environmental data. of the 11 sections shown in figure 47, 9 are located in the western region of northern Alaska and 2 are adjacent to Umiat test well 11 in the eastern region. Proceeding from west to east, the faunas are briefly described and correlated with known sections. Characteristic foraminiferal species are shown in plate 19.

Starve section; Seaview Syncline.--DeLong

Mountains D-4 quadrangle, measured along the south face of Seaview Syncline beginning at lat $68^{\circ} 50^{\prime} 56^{\prime \prime}$ N., long $163^{\circ} 51^{\prime} 40^{\prime \prime} \mathrm{W}$.

The section consists of $57.6 \mathrm{~m}$ of massive gray sandstone and black shale of the Torok and
Kukpowruk Formations. Sample No. 77AAH72, 47.9 $m$ above the base of the section in black shale of the Kukpowruk Formation, contains a poorly preserved Albian to possibly Cenomanian assemblage with Verneuilinoides borealis Tappan, Hippocrepina barksdalei (Tappan), Bathysiphon brosgei Tappan, and Haplophragmoides topagorukensis Tappan. Foreshore environments are indicated by the biotic association.

Tupikchak Mountain section.--DeLong Mountains and Misheguk Mountains quadrangles, 1,250.6 m of Torok and Kukpowruk Formations measured along the Kokolik River. The section starts at lat $68^{\circ} 50^{\prime} 50^{\prime \prime} \mathrm{N}$., long $162^{\circ} 00^{\prime} 40^{\prime \prime} \mathrm{W}$. on the northwest side of the river and traverses up Tupikchak Mountain.

The section consists predominantly of silty shale and some massive or bioturbated sandstone in the lower half and increases in sandstone having high-angle cross-stratification, graded bedding, and root casts typical of channel deposits in the upper half. Sample No. 77AJF21 from black shale of the Torok Formation at the base of the section contains an abundant and moderately diverse Albian fauna. Characteristic species include Verneuilinoides borealis Tappan, Ammobaculites wenonahae Tappan, Quadrimorphina ruckerae (Tappan), Pseudobolivina rayi (Tappan), and Uvigerinammina manitobensis (Wickenden). Middle to outer neritic water depths are implied by this association. A much-reduced fauna was recovered from Sample No. 77AJF22 in black shales of the Torok Formation $1.5 \mathrm{~m}$ above the base of the section. The only species present are Haplophragmoides cf. H. topagorukensis Tappan and Nodosaria cf. N. doliiformis Eichenberg. Albian offshore environments are indicated by this meager assemblage. Sample Nos. 77AJF28 and $77 \mathrm{AJF} 32$ from calcareous sandstones that are 270.4 and $416.2 \mathrm{~m}$, respectively, above the base of the Kukpowruk Formation contain rare, poorly preserved specimens of Haplophragmoides. Little information can be deduced from these occurrences other than the suggestion of marginal marine environmental conditions. Sample No. 77AJF33, from black shale $457.8 \mathrm{~m}$ above the base of the Kukpowruk Formation, records a return to more marine environments within the Albian section. Species include Haplophragmoides topagorukensis, Ammobaculites wenonahae, and Uvigerinamina manitobensis.

Kukpowruk type section (includes the type Kukpowruk Formation).--Point Lay B-2, B-3 quadrangles. Measured on north $1 \mathrm{imb}$ of Archimedes Anticline beginning at lat $69^{\circ} 15^{\prime} 06^{\prime \prime}$ N., long $164^{\circ} 42^{\prime} 31^{\prime \prime}$ W.

The measured section consists of $666.8 \mathrm{~m}$ of black shale and siltstone with bioturbated, cross-laminated sandstone, carbonaceous partings, and root casts becoming abundant in the upper half. Samples that contain foraminifers and their lithologies are shown in table 10. 
Table 10.--Foraminifer-bearing samples from the Kukpowruk type section

\begin{tabular}{|c|c|c|c|}
\hline Formation & $\begin{array}{l}\text { Sample No. } \\
\text { 77 AAH }\end{array}$ & $\begin{array}{l}\text { Meters } \\
\text { above base }\end{array}$ & Lithology \\
\hline $\begin{array}{l}\text { Kukpowruk and Corwin Formations, } \\
\text { undifferentiated. }\end{array}$ & $\begin{array}{l}157 \\
156 \mathrm{~B} \\
155\end{array}$ & $\begin{array}{l}448.8 \\
439.9 \\
404.0\end{array}$ & $\begin{array}{l}\text { Shale. } \\
\text { Black shale. } \\
\text { Black shale. }\end{array}$ \\
\hline Kukpowruk Formation--- & $\begin{array}{l}154 \mathrm{~A} \\
154 \\
152 \\
150\end{array}$ & $\begin{array}{l}317.7 \\
194.8 \\
130.2 \\
104.6\end{array}$ & $\begin{array}{l}\text { Black shale. } \\
\text { Black shale. } \\
\text { Black shale. } \\
\text { Black shale. }\end{array}$ \\
\hline Torok Formation-- & 146 & 0 & Black shale. \\
\hline
\end{tabular}

Sample Nos. 77AAH146 to 77AAH154A within the Kukpowruk Formation contain a late Albian assemblage with Ammobaculites fragmentarius Cushman, $A$. obliquus Loeblich and Tappan, Gaudryina canadensis Cushman, Psamminopelta bowsheri Tappan, and Trochammina mcmurrayensis Me1lon and Wall among others. Foreshore depositional environments are indicated by the biotic association; evidence of shoaling upward is expressed by species composition of the foraminiferal fauna, the reduction of specimen size and grain size in the agglutinated species, and the increase in carbonaceous material. Sample Nos. 77AAH155 to 77AAH157 from the undifferentiated Kukpowruk and Corwin Formations contain a late Albian fauna with Gaudryina canadensis Cushman, Trochammina mcmurrayensis, Haplophragmoides cf. H. hendersonense Stelck and Wa11, Ammobaculites obliquus, Uvigerinammina manitobensis (Wickenden), and Psamminopelta bowsheri. This assemblage is indicative of a marginal-marine environment. The Kukpowruk River section thus correlates with the upper portion of the Grandstand Formation and the Killik Tongue in Umiat test well 11. The transgressive environmental sequence and foraminiferal fauna of the Kukpowruk type section are similar to those of the early to middle McMurray Formation of the lower Athabasca River area of northeastern Alberta (Mellon and Wall, 1956); however, the Kukpowruk type section appears to be younger in age.

Archimedes Anticline section.--Point Lay A-2 quadrangle. Measured along south 1 imb of anticline on the east side of the Kukpowruk River beginning at lat $69^{\circ} 14^{\prime} 58^{\prime \prime}$ N., long $162^{\circ} 41^{\prime} 28^{\prime \prime} \mathrm{W}$.

The section, which lies stratigraphically below the Kukpowruk type section, is represented by $948.2 \mathrm{~m}$ of mostly black shale with some interbeds of bioturbated sandstone that contain ripple laminations and low-angle crosslaminations. Sample No. 77AJF2, from $18.6 \mathrm{~m}$ above the base in black shale of the Torok Formation, contains a meager fauna of Haplophragmoides topagorukensis Tappan, Uvigerinammina manitobensis (Wickenden), and Ammobaculites fragmentarius Cushman. Late Albian offshore environmental conditions are suggested by this assemblage. Sample No. 77AJF3, from black shales $83.2 \mathrm{~m}$ above the base of the Kukpowruk Formation, contains
Verneuilinoides borealis Tappan, Pseudobolivina rayi (Tappan), Ammobaculites wenonahae Tappan, and Trochammina rainwateri Cushman and Applin among others. This middle and late Albian assemblage indicates a continuation of offshoremarine environmental conditions. A much reduced fauna of specimens attributed to

Haplophragmoides cf. H. hendersonense Stelck and Wall was recovered from Sample Nos. 77AJF6 and 77AJF9 from black shales 324.6 and $565.3 \mathrm{~m}$ above the base of the Kukpowruk Formation, respectively. Sample No. 77AJF11 from silty shale just beneath a massive sandstone bed $631.1 \mathrm{~m}$ above the base in the Kukpowruk Formation includes Gaudryina canadensis Cushman, Miliammina manitobensis Wickenden, Psamminopelta bowsheri Tappan, and Hippocrepina barksdalei (Tappan). This assemblage implies a shoaling of the environment to foreshore conditions in a trend that may have started earlier in the section near Sample No. 77AJF6. A middle and late Albian age is indicated for Sample No. 77AJF11, thus correlating the Archimedes section with the Torok and Grandstand Formations of Umiat test well 11.

Igloo Mountain section.--DeLong Mountains D-2 quadrangle. The section was measured on the northwest side of Igloo Mountain in a dry canyon beginning at lat $68^{\circ} 46^{\prime} 53^{\prime \prime} \mathrm{N}$., long $162^{\circ} 57^{\prime} 20^{\prime \prime} \mathrm{W}$.

The section is represented by $317 \mathrm{~m}$ of black shale and bioturbated sandstone interbeds that exhibit low-angle cross-laminations, scour-and-fill structures, and bivalve shells. Sample No. 77AAH189 from black shale of the Torok Formation at $1.2 \mathrm{~m}$ above the base contains Verneuilinoides borealis Tappan, Ammobaculites wenonahae Tappan, Pseudobolivina rayi (Tappan), Miliammina manitobensis Wickenden, and

Saracenaria grandstandensis Tappan among others. Middle and late Albian offshore depositional environments are indicated. Sample No. 77AAH191, from black shale $17.4 \mathrm{~m}$ above the base in the Kukpowruk Formation, yielded two specimens of Haplophragmoides cf. H. hendersonense Stelck and Wall, perhaps signifying a shoaling to foreshore condition.

Kokolik Warp Syncline section.--Utukok River A-5 quadrangle. The section is located on the north flank of Kokolik Warp Syncline along the west side of a dry stream beginning at lat $69^{\circ} 10^{\prime} 07^{\prime \prime} \mathrm{N}$., long $161^{\circ} 35^{\prime} 07^{\prime \prime}$ W. A $4.8-\mathrm{km}$ east-lateral offset was then made, and sampling continued to the axis of the syncline.

A 2,119-m succession of black shale with occasional sandstone interbeds in the lower half and an increase in sandstone beds having low- to moderate-angle cross-stratification, ripple laminations, coal beds and petrified wood, and channel fill in the upper half was measured at this section. Sample No. 77 ACH140 from black shale within and $1.5 \mathrm{~m}$ above the base of the Torok Formation is represented by Verneuilinoides 
borealis Tappan, Ammobaculites wenonahae Tappan, Uvigerinammina manitobensis (Wickenden), and Haplophragmoides topagorukensis Tappan. This assemblage represents a middle and late Albian offshore environment. Sample No. 77ACH141 in bioturbated black shale $154.0 \mathrm{~m}$ above the base but still within the Torok Formation contains a much reduced fauna consisting of $H$. topagorukensis and $V$. borealis of similar age. The poor faunal recovery continues into Sample Nos. 77ACH142 and 77ACH145 from shale 259.2 and $370.3 \mathrm{~m}$ above the base of the section in the Kukpowruk Formation. Species are limited to Haplophragmoides topagorukensis, $H$. cf. $H$. hendersonense Stelck and Wa11, and Uvigerinammina manitobensis; and the biotic association is suggestive of foreshore environments. Sample No. 77ACH148, from a sequence of black shale containing coaly material $611.3 \mathrm{~m}$ above the base of the section in the undifferentiated Kukpowruk and Corwin Formations, contains Trochammina rainwateri Cushman and Applin, Verneuilinoides borealis, Psamminopelta bowsheri Tappan, and Eurycheilostoma grandstandensis Tappan of middle and late Albian age. The assemblage implies increased marine conditions within a sequence of foreshore deposits. The Kokolik Warp Syncline section correlates with the Torok and Grandstand Formations of Umiat test we11 11.

Folsom Point Syncline section.--Utukok River A-3 quadrangle. The section was measured along the west side of the Utukok River on the north limb of the Folsom Point Syncline beginning at lat $69^{\circ} 10^{\prime} 43^{\prime \prime} \mathrm{N}$., long $162^{\circ} 38^{\prime} 28^{\prime \prime} \mathrm{W}$.

The section consists of $818.6 \mathrm{~m}$ of black shale and bioturbated sandstone interbeds with scour-fill structures, clay rip-ups, crosslaminations, carbonaceous material, and channels. Sample No. 77AAH6AR from black shale $161.9 \mathrm{~m}$ above the base of the section in the Kukpowruk Formation contains Verneuilinoides borealis Tappan, Ammobaculites wenonahae Tappan, A. fragmentarius Cushman, Quadrimorphina ruckerae (Tappan), and Uvigerinammina manitobensis (Wickenden) among others. Middle and late Albian nearshore environments are indicated by this association. Sample Nos. 77AAH7AR and 77AAH8AR from shale and siltstone 257.3 and $279.6 \mathrm{~m}$ above the base, respectively, and still within the Kukpowruk Formation yielded only rare specimens of Haplophragmoides. Again the implication of shoaling to foreshore conditions is suggested by this meager fauna.

Meat Mountain section.--Mishiguk Mountains quadrangle. The section extends up the northwest spur of Meat Mountain, beginning at lat $68^{\circ} 58^{\prime} 55^{\prime \prime}$. N., long $160^{\circ} 51^{\prime} 25^{\prime \prime} \mathrm{W}$.

The 446.0-m section contains poorly exposed shale sequences with interbeds of sandstone that contain ripple laminations, bioturbation and trails, low- to high-angle cross-stratification, raindrop imprints, and scour-and-fill structures. Rare, poor1y preserved foraminifers consisting of Haplophragmoides cf. H. topagorukensis Tappan, $H$. cf. $H$. hendersonense Stelck and Wall, Verneuilinoides borealis Tappan, and Dentalina cf. D. praecommunis Tappan were recovered from shales in Sample Nos. 77AAH6MM, 77AAH7MM, and 77AAH8MM from 91.8, 103.7, and $115.9 \mathrm{~m}$ above the base, respectively, in the Kukpowruk Formation. Foreshore to shoreface Albian depositional environments are implied by this fauna.

\section{Lookout Ridge Syncline section.--Utukok} River quadrangle. The section is located on a ridge east of an unnamed stream on the northwest flank of Lookout Ridge Syncline beginning at lat $69^{\circ} 08^{\prime} 40^{\prime \prime} \mathrm{N}$., long $159^{\circ} 41^{\prime} 30^{\prime \prime} \mathrm{W}$.

A poorly exposed 518.9-m-thick shale sequence with interbeds of bioturbated sandstone showing ripple laminations, low-angle crossstratification, carbonaceous material, and scour-and-fill structures characterizes this section. Four samples from shale intervals within the Kukpowruk Formation contain a poorly preserved fauna of Albian Age. Sample No. 77AAH4LO, $7.3 \mathrm{~m}$ above the base, contains Haplophragmoides topagorukensis Tappan and Dentalina cf. D. basiplanata Cushman. Sample No. 77AAH6LO, from $23.8 \mathrm{~m}$ above the base, includes Trochammina rainwateri Cushman and Applin, Miliammina ischnia Tappan, Ammobaculites fragmentarius Cushman, and Spiroplectammina cf. S. ammovitrea Tappan. Sample No. 77AAH7LO, from $90.2 \mathrm{~m}$ above the base, is represented by Haplophragmoides topagorukensis Tappan, $H$. cf. $H$. hendersonense Stelck and Wall, Uvigerinammina cf. U. manitobensis (Wickenden), and Gavelinella cf. G. awunensis Tappan. And, finally, Sample No. 77AAH9LO, from $198.5 \mathrm{~m}$ above the base, contains Verneuilinoides borealis Tappan, Valvulineria loetterli Tappan, and Trochammina cf. T. rainwateri Cushman and Applin. Foreshore environmental conditions are indicated by this biotic association.

Ninuluk Bluff section.--Ikpikpuk River quadrangle. Measured up the Ninuluk Bluff cutbank on the southeast side of Colville River at lat $69^{\circ} 07^{\prime} 45^{\prime \prime}$ N., long $153^{\circ} 16^{\prime} 55^{\prime \prime} \mathrm{W}$.

A section $315.2 \mathrm{~m}$ thick is represented by bioturbated sandstone with low-angle crossstratification, carbonaceous material, root casts, bivalve shells, and ripple laminations interbedded with siltstone and shale sequences that decrease upwards in both abundance and thickness. The eight samples taken from shale and siltstone of the Seabee Formation (table 11) in the upper portion of the section contain the same fauna consisting of Trochammina whittingtoni Tappan and Verneuilinoides fischeri Tappan. A Turonian or Senonian Age is implied for this limited fauna, representative of offshore to foreshore depositional environments.

Tuktu Bluff section.--Chandler Lake quadrangle. Measured section at Tuktu Bluff, a cutbank of the Chandler River at lat $68^{\circ} 43^{\prime} 30^{\prime \prime}$ N., long $152^{\circ} 15^{\prime} 30^{\prime \prime} \mathrm{W}$. 
Table 11.--Foraminifer-bearing samples from the Seabee Formation in the Ninuluk Bluff section

\begin{tabular}{|c|c|c|c|c|c|}
\hline $\begin{array}{l}\text { Sample No. } \\
\quad 77 \mathrm{ACH}\end{array}$ & $\begin{array}{c}\text { Meters } \\
\text { above base }\end{array}$ & Lithology & $\begin{array}{l}\text { Sample No. } \\
77 \mathrm{ACH}\end{array}$ & $\begin{array}{l}\text { Meters } \\
\text { above base }\end{array}$ & Lithology \\
\hline 296 & 311.7 & $\begin{array}{l}\text { Laminated silt- } \\
\text { stone-mudstone. }\end{array}$ & $\begin{array}{l}292 \\
291\end{array}$ & $\begin{array}{l}301.5 \\
299.7\end{array}$ & $\begin{array}{l}\text { Black shale. } \\
\text { Siltstone. }\end{array}$ \\
\hline 295 & 307.6 & Black shale. & 289 & 283.9 & Black shale. \\
\hline 294 & 304.3 & Black shale. & 288 & 272.0 & Black shale. \\
\hline 293 & 302.8 & Black shale. & & & \\
\hline
\end{tabular}

Black shale of the Torok Formation is overlain by siltstone, shale, and sandstone interbeds of the Tuktu Formation in the $439.0 \mathrm{~m}$ of measured section. The sandstone beds are bioturbated and contain ripple marks, moderateangle cross-stratification, carbonaceous debris, and flaser bedding. Samples with foraminifers are shown in table 12. All samples contain. Verneuilinoides borealis Tappan, which is characteristic of the middle and late Albian.

Table 12.--Foraminifer-bearing samples from the Tuktu Bluff section

\begin{tabular}{lccl}
\hline Formation & $\begin{array}{c}\text { Sample No. } \\
\text { 77 AAH }\end{array}$ & $\begin{array}{c}\text { Meters } \\
\text { above base }\end{array}$ & Lithology \\
\hline Tuktu Formation & 26TB & 268.1 & Siltstone. \\
Torok Formation & 9TB & 24.6 & Black shale. \\
& 8TB & 22.9 & Black shale. \\
& 7TB & 19.8 & Black shale. \\
& 6TB & 16.8 & Black shale. \\
& 5TB & 13.7 & Black shale. \\
& 4TB & 10.7 & Black shale. \\
& 3TB & 7.6 & Black shale. \\
& 2TB & 4.6 & Black shale. \\
& Black shale. \\
& & 1.5 & \\
\hline
\end{tabular}

Sample No. 77AAH1TB contains the most diverse fauna with Ammobaculites fragmentarius Cushman, Eurycheilostoma grandstandensis Tappan, Pseudonodosaria kirschneri (Tappan), Lenticulina erecta (Perner), and Valvulineria loetterli (Tappan) among others. In addition, the assemblage includes rare ostracodes, echinoid debris, and radiolarians that are indicative of offshore-neritic to bathyal conditions. Sample No. 77AAH2TB is similar in composition, but also contains Dentalina dettermani Tappan, Ammodiscus rotalarius Loeblich and Tappan, and Ammobaculites cf. A. wenonahae Tappan. This fauna continues through Sample No. 77AAH3TB but is much reduced in Sample Nos. 77AAH4TB and 77AAH5TB. In Sample No. 77AAH6TB the diversity increases, with Haplophragmoides topagorukensis Tappan, Verneuilinoides borealis, and species of Ammobaculites continuing throughout the remaining samples. Additional species include rare occurrences of Psamminopelta bowsheri Tappan in Sample No. 77AAH6TB, Pseudonodosaria kirschneri in Sample No. 77AAH7TB, and Gavelinella cf. $G$. intermedia (Berthelin) in Sample No. 77AAH26TB. The middle and late Albian foraminiferal faunas and offshore depositional environments of the Tuktu Bluff samples correlate with those of the upper part of the Torok and Grandstand Formations of Umiat test wel1 11.

In summary, surface sections from the western region (A to $\mathrm{H}$ in $\mathrm{fig}$. 47) are represented by a less diverse, more poorly preserved foraminiferal fauna when compared to coeval assemblages in Umiat test we11 11 and the Tuktu Bluff section in the eastern region. Faunas from the Torok Formation are most similar in both faunal content and depositional environment. This is especially true of the basal samples from the Torok Formation at Tupikchak Mountain. Nevertheless, the species represented, their preservation, and the 1ithology and associated biogenic debris suggest shallower water depths for the western region. Assemblages from the Kukpowruk Formation of the western region, however, are noticeably different from faunas in the Grandstand Formation of Umiat test well 11. Depositional environments are represented by foreshore and nearshore marine associations compared to correlative offshore assemblages that are typical of the Grandstand Formation in the eastern region. 
PLATE 18 we11 11 .

Characteristic species from upper part of Torok Formation and Nanushuk Group of Umiat test

Figure 1. Miliammina awunensis Tappan, core 59, 890-893 m, scale $60 \mu \mathrm{m}$.

2. Miliammina manitobensis Wickenden, core $61,1,003-1,007 \mathrm{~m}$, scale $100 \mu \mathrm{m}$.

3- 4. Haplophragmoides topagorukensis Tappan, ditch sample, 972-975 m, scale $100 \mu \mathrm{m}$.

5. Ammobaculites wenonahae Tappan, core $55,823-826 \mathrm{~m}$, scale $100 \mu \mathrm{m}$.

6. Haplophragmoides rota Nauss, ditch sample, $192-195 \mathrm{~m}$, scale $100 \mu \mathrm{m}$.

7. Trochammina umiatensis Tappan, ditch sample, $844-847 \mathrm{~m}$, scale $100 \mu \mathrm{m}$.

8- 9. Trochammina rutherfordi Stelck and Wal1, core 41, 656-659 m, scale $50 \mu \mathrm{m}$.

8. Spiral view.

9. Peripheral view.

10. Gaudryina canadensis Cushman, core $56,859.5-862.5 \mathrm{~m}$, scale $50 \mu \mathrm{m}$.

11. Verneuilinoides borealis Tappan, core $55,823-826 \mathrm{~m}$, scale $50 \mu \mathrm{m}$.

12-13. Marginulina gatesi Tappan, ditch sample, $972-975 \mathrm{~m}$, scale $100 \mu \mathrm{m}$.

12. Side view.

13. Face view.

14. Praebulimina nannina (Tappan), ditch sample, $972-975 \mathrm{~m}$, scale $30 \mu \mathrm{m}$.

15-16. Globorotalites alaskensis Tappan, core 61, 1,003-1,007 m, scale $30 \mu \mathrm{m}$.

15. Umbilical view.

16. Peripheral view.

17-18. Gavelinella stictata (Tappan), core $55,823-826 \mathrm{~m}$, scale $30 \mu \mathrm{m}$.

17. Umbilical view.

18. Peripheral view. 


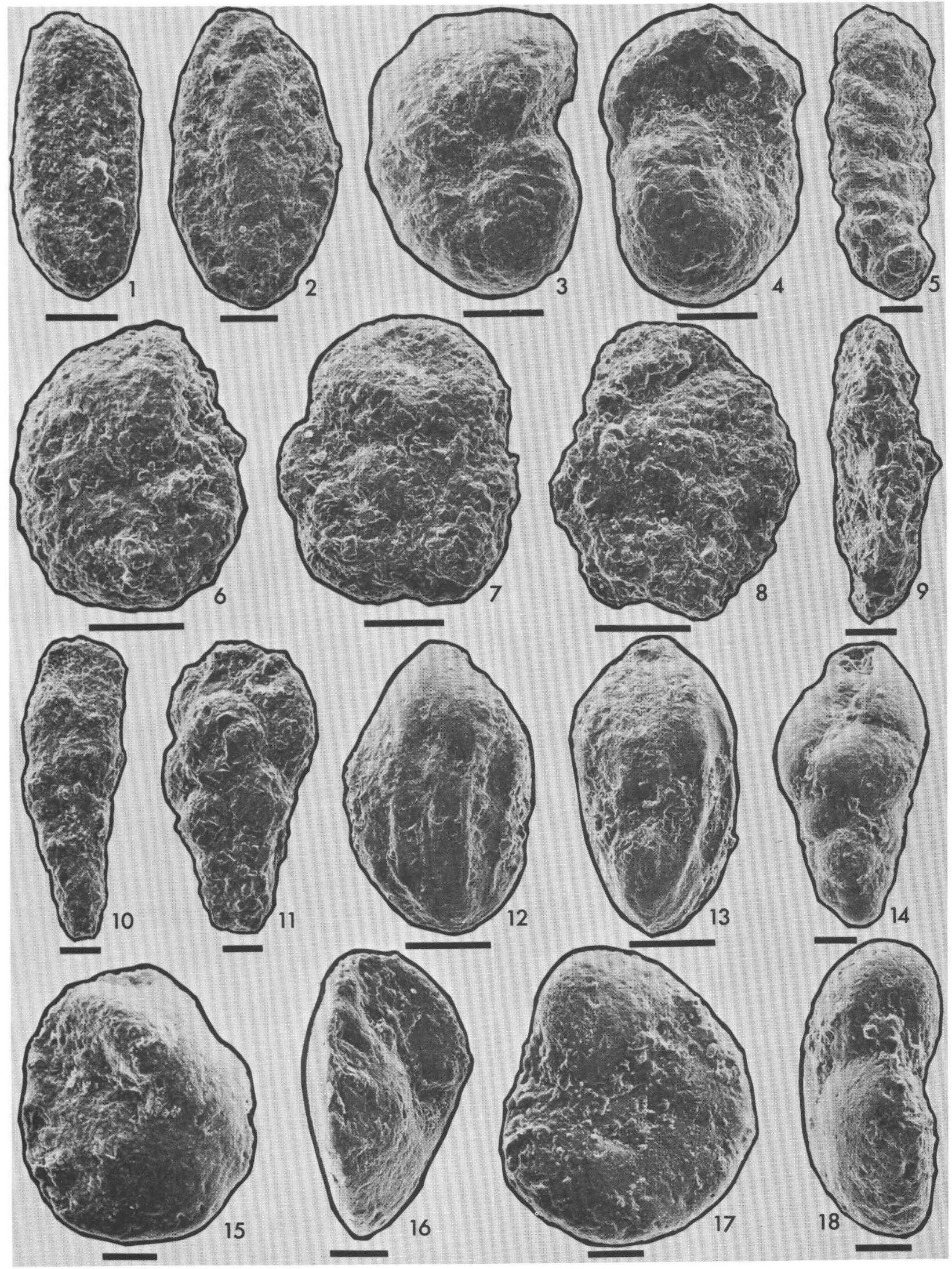


Characteristic species from surface sections.

Figure 1. Ammodiscus rotalarius Loeblich and Tappan, Tuktu Bluff, Torok Formation, Sample No. 77AAH2TB, scale $50 \mu \mathrm{m}$.

2. Psamminopelta bowsheri Tappan, Kukpowruk type section, Torok Formation, Sample No. 77AAH146, scale $100 \mu \mathrm{m}$.

3. Haplophragmoides topagorukensis Tappan, Tuktu Bluff, Torok Formation, Sample No. 77AAH1TB, scale $100 \mu \mathrm{m}$.

4- 5. Ammobaculites fragmentarius Cushman, scale $100 \mu \mathrm{m}$.

4. Tuktu Bluff, Torok Formation, Sample No. 77AAH1TB.

5. Tuktu Bluff, Torok Formation, Sample No. 77AAH2TB.

6- 7. Trochammina mcmurrayensis Mellon and Wa11, Kukpowruk type section, Kukpowruk and Corwin Formations, undifferentiated, Sample No. 77AAH155, scale $100 \mu \mathrm{m}$.

8. Pseudobolivina rayi (Tappan), Archimedes Anticline, Kukpowruk Formation, Sample No. 77AJF3, scale $50 \mu \mathrm{m}$.

9-10. Ammobaculites obliquus Loeblich and Tappan, Kukpowruk type section, scale $100 \mu \mathrm{m}$.

9. Kukpowruk and Corwin Formations, undifferentiated, Sample No. 77AAH155.

10. Torok Formation, Sample No. 77AAH146.

11-13. Trochammina whittingtoni Tappan, Ninuluk Bluff, Seabee Formation, Sample No. 77ACH288.

11. Spiral view, scale $150 \mu \mathrm{m}$.

12. Peripheral view, scale $100 \mu \mathrm{m}$.

13. Spiral view, scale $100 \mu \mathrm{m}$.

14. Verneuilinoides borealis Tappan, Archimedes Anticline, Kukpowruk Formation, Sample No. 77AJF3, scale $50 \mu \mathrm{m}$.

15. Ammobaculites wenonahae Tappan, Tupikchak Mountain, Torok Formation, Sample No. 77AJF21, scale $150 \mu \mathrm{m}$.

16. Gaudryina canadensis Cushman, Kukpowruk type section, Kukpowruk Formation, Sample No. 77AAH154, scale $100 \mu \mathrm{m}$.

17. Pseudonodosaria kirschneri Tappan, Tuktu Bluff, Torok Formation, Sample No. $77 \mathrm{AAH} 1 \mathrm{~TB}$, scale $100 \mu \mathrm{m}$.

18. Eurycheilostoma grandstandensis Tappan, Tuktu Bluff, Torok Formation, Sample No. 77AAH1TB, scale $30 \mu \mathrm{m}$.

19-20. Valvulineria loetterli (Tappan), Tuktu Bluff, Torok Formation, Sample No. 77AAH1TB.

19. Umbilical view, scale $60 \mu \mathrm{m}$.

20. Peripheral view, scale $50 \mu \mathrm{m}$. 


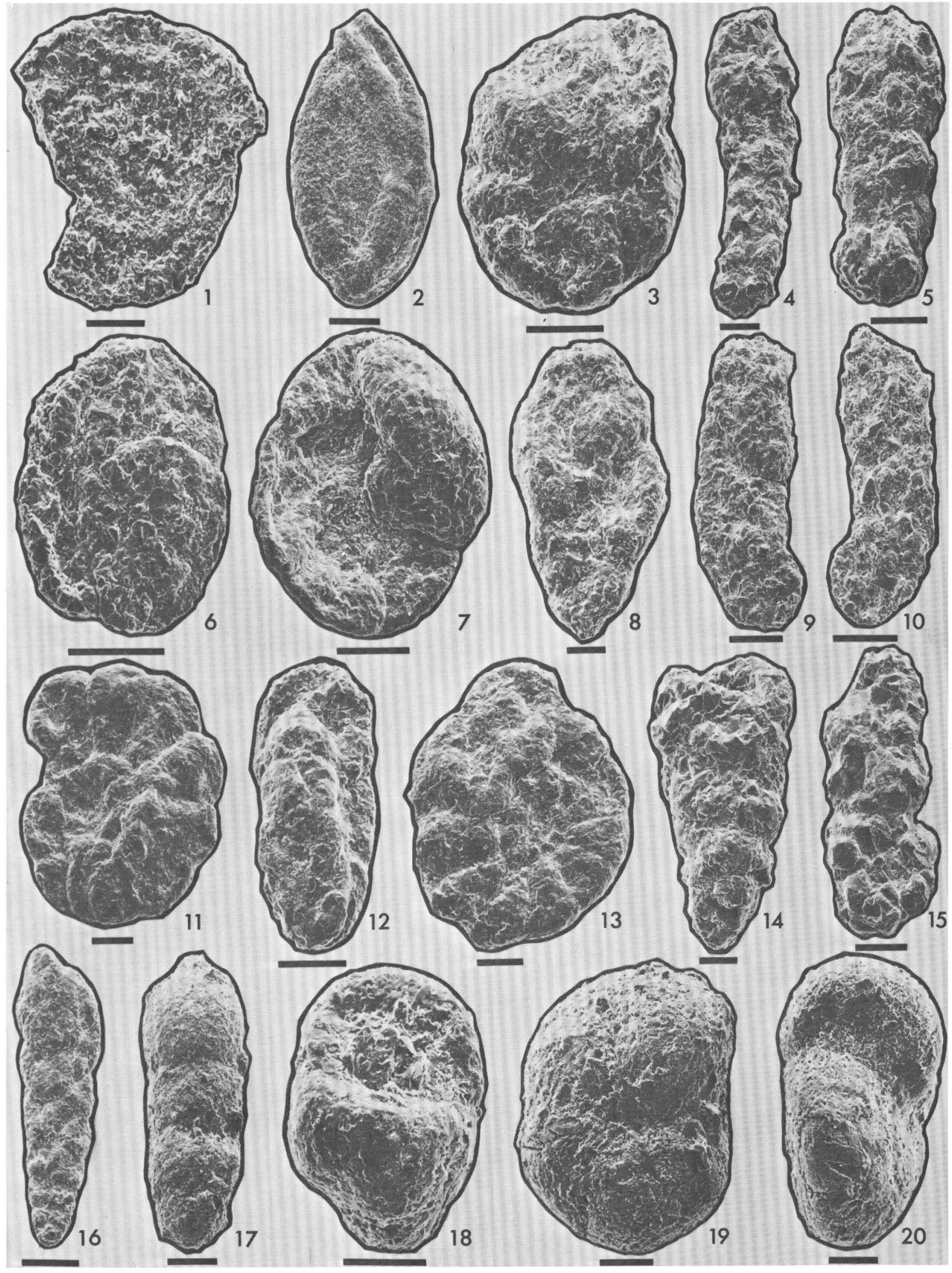




\section{REFERENCES CITED}

Alaska Geological Society Newsletter, 1978, North Slope stratigraphic nomenclature: Anchorage, Alaska, May issue.

American Petroleum Institute, 1960, Recommended practice for core-analysis procedure: American Petroleum Institute Recommended Practices 40, $55 \mathrm{p}$.

Barker, Colin, 1974a, Pyrolysis techniques for source-rock evaluation: American Association of Petroleum Geologists Bulletin, v. 58, p. 2349-2361.

$1974 \mathrm{~b}$, Programmed-temperature pyrolysis of vitrinites of various rank: Fuel, v. 53, p. $176-177$.

Beikman, H. M., 1976, Preliminary geologic map of Northern Alaska: U.S. Geological Survey Miscellaneous Field Studies Map, MF-789, 2 sheets, scale $1: 1,000,000$.

1978, Preliminary geologic map of Alaska: U.S. Geological Survey map, scale $1: 2,500,000$.

Bergquist, H. R., 1966, Micropaleontology of the Mesozoic rocks of northern Alaska: U.S. Geological Survey Professional Paper 302-D, p. 93-227.

Brenner, G. J., 1963, The spores and pollen of the Potomac Group of Maryland: Department of Geology, Mines and Water Resources, State of Maryland, Bulletin 27, 215 p. 1976, Middle Cretaceous floral provinces and early migrations of angiosperms, in Beck, C. B., ed., Origin and early evolution of angiosperms: New York, Columbia University Press, p. 23-47.

Brideaux, W. W., 1971, Palynology of the Lower Colorado Group, central Alberta, Canada--I, Introductory remarks; Geology and microplankton studies: Palaeontographica, pt. B, v. 135, p. 53-114, p1. 21-30.

1977, Taxonomy of Upper Jurassic-Lower Cretaceous microplankton from the Richardson Mountains, District of Mackenzie, Canada: Geological Survey of Canada Bulletin 281, p. 1-89, pI. 1-16.

Brideaux, W. W., and Fisher, M. J., 1976, Upper Jurassic-Lower Cretaceous dinoflagellate assemblages from Arctic Canada: Geological Survey of Canada Bulletin 259, p. 1-53, pl. $1-7$.

Brideaux, W. W., and McIntyre, D. J., 1975, Miospores and microplankton from AptianAlbian rocks along Horton River, District of Mackenzie: Geological Survey of Canada Bulletin 252, p. 1-85, p1. 1-14.
Brosgé, W. P., and Reiser, H. N., 1971, Preliminary bedrock geology map of the Wiseman and eastern Survey Pass quadrangles, Alaska: U.S. Geological Survey Open-file report, scale 1:250,000.

Brosgé, W. P., and Tailleur, I. L., 1970, Depositional history of northern Alaska, and Discussion, in Adkison, W. L., and Brosgé, M. M. eds., Geological seminar on the North Slope of Alaska, Palo Alto, Calif., 1970: Los Angeles, Calif., American Association of Petroleum Geologists, Pacific Section Meeting, Proceedings, p. D1-D18. 1971, Northern Alaska petroleum province, in Cram, I. H., ed., Future petroleum provinces of the United States--Their geology and potential: American Association of Petroleum Geologists Memoir 15, p. 6899.

Brosgé, W. P., and Whittington, C. L., 1966, Geology of the Umiat-Maybe Creek region, Alaska: U.S. Geological Survey Professional Paper 303-H, p. 501-638.

Campbel1, C. V., 1971, Depositional mode1--Upper Cretaceous Gallup beach shoreline, Ship Rock area, northwestern New Mexico: Journal of Sedimentary Petrology, v. 41, p. 395409 .

Carter, R. D., Mul1, C. G., Bird, K. J., and Powers, R. B., 1977, The petroleum geology and hydrocarbon potential of Naval Petroleum Reserve No. 4, North Slope, Alaska: U.S. Geological Survey Open-File Report 77-475, $61 \mathrm{p}$.

Chapman, R. M., Detterman, R. L., and Mangus, M. D., 1964, Geology of the Killik-Etivluk Rivers region, Alaska: U.S. Geological Survey Professional Paper 303-F, p. 325407.

Chapman, R. M., and Sable, E. G., 1960, Geology of the Utukok-Corwin region, northwestern Alaska: U.S. Geological Survey Professional Paper 303-C, p. 47-174.

Claypool, G. E., Lubeck, C. M., Baysinger, J. P., and Ging, T. G., 1977, Organic geochemistry, in Scholle, P. A., ed., Geological studies on the COST no. B-2 well, U.S. Mid-Atlantic Outer Continental Shelf Area: U.S. Geological Survey Circular 750 , p. 46-59.

Claypool, G. E., and Reed, P. R., 1976, Thermalanalysis technique for source-rock evaluation--Quantitative estimate of organic richness and effect of lithologic variation: 
American Association of Petroleum Geologists Bulletin, v. 60, p. 608-626.

Collins, F. R., 1958a, Test wells, Umiat area, Alaska, with Micropaleontologic study of the Umiat field, northern Alaska, by H. R. Bergquist: U.S. Geological Survey Professional Paper 305-B, p. 71-206. $1958 \mathrm{~b}$, Test we11s, Topagoruk area, Alaska, with Micropaleontologic study of the Topagoruk test wells, northern Alaska, by H. R. Bergquist: U.S. Geological Survey Professional Paper 305-D, p. 265-316. $1958 \mathrm{c}$, Test wells, Meade and Kaolak areas, Alaska, with Micropaleontology of Meade test well 1 and Kaolak test well 1, northern Alaska, by H. R. Bergquist: U.S. Geological Survey Professional Paper 305-F, p. 341376.

1959, Test wells, Square Lake and Wolf Creek areas, Alaska, with Micropaleontology of Square Lake test well 1 and the Wolf Creek test wells, northern Alaska, by H. R. Bergquist: U.S. Geological Survey Professional Paper 305-H, p. 423-484. [Professional Paper 305, issued only as separate chapters under the general title, Exploration of Naval Petroleum Reserve No. 4 and adjacent areas, northern Alaska, part 5, Subsurface geology and engineering data.]

Collins, F. R., and Robinson, R. M., 1967, Subsurface stratigraphic, structural, and economic geology, northern Alaska: U.S. Geological Survey Open-file report, 252 p.

Cookson, I. C., and Eisenack, A., 1974, Mikroplankton aus australischen Mesozoischen und Tertiären sedimenten:

Palaeontographica, Abt. B, v. 148, p. 4693, p1. 20-29.

Detterman, R. L., 1956, New and redefined nomenclature of Nanushuk Group, in Gryc, George, and others, Mesozoic sequence in Colville River region, northern Alaska: American Association of Petroleum Geologists Bulletin, v. 40, p. 233-244.

1973, Mesozoic sequence in Arctic Alaska, in Pitcher, M. G., ed., Arctic geology: American Association of Petroleum Geologists Memoir 19, p. 376-395.

Detterman, R. L., Bickel, R. S., and Gryc, George, 1963, Geology of the Chandler River region, Alaska: U.S. Geological Survey Professional Paper 303-E, p. 223-324.

Detterman, R. L., Reiser, H. N., Brosgé, W. P., and Dutro, J. T., Jr., 1975, Post-Carboniferous stratigraphy, northeastern Alaska: U.S. Geological Survey Professional Paper 886, 46 p.

Dickinson, W. R., 1970, Interpreting detrita1 modes of graywacke and arkose: Journal of Sedimentary Petrology, v. 40, p. 695-707.

Dow, W. G., 1977a, Petroleum source beds on continental slopes and rises, in Yarborough, Hunter, Emery, K. 0., Dickinson, W. R., Seely, D. R.., Dow, W. G., Curray, J. R., and Vail, P. R., Geology of continental margins: American Association of Petroleum Geologists Continuing Education Notes Series No. 5, p. D1-D37.

1977b, Kerogen studies and geological interpretations, in Hitchon, B., ed., Application of geochemistry to the search for crude oil and natural gas: Journal of Geochemical Exploration, v. 7, no. 2, p. 79-99.

Espach, R. H., 1951, Recoverable petroleum reserves in the Umiat structure, Naval Petroleum Reserve No. 4, Alaska: U.S. Bureau of Mines Petroleum and Natural Gas Branch Open-file report.

Espitalie, J., Madec, M., Tissot, B., Mennig, J. J., and Leplat, P., 1977, Source rock characterization method for petroleum exploration: Houston, Proceedings of 9 th Annual offshore Technology Conference, p. 439-444.

Fisher, W. L., Brown, L. F., Jr., Scott, A. J., and McGowen, J. H., 1969, Delta systems in the exploration for oil and gas--A research colloquium, August 27-29, 1969: University of Texas Bureau of Economic Geology, 78 p., 168 figs., 24 p. bibliography.

Folk, R. L., 1968, Petrology of sedimentary rocks: Austin, Tex., Hemphill's, 170 p.

Fox, J. E., Lambert, P. W., Pitman, J. K., and Wu, C. H., 1979, A study of reservoir characteristics of the Nanushuk and Colville Groups, Umiat test well 11, National Petroleum Reserve in Alaska: U.S. Geological Survey Circular (in press).

Grantz, Arthur, Holmes, M. L., and Kososki, B. A., 1976, Geologic framework of the Alaskan continental terrace in the Chukchi and Beaufort Seas, in Canadian continental margins: Canadian Society of Petroleum Geologists Memoir 4, p. 669-700.

Grantz, Arthur, and Kirschner, C. E., 1976, Tectonic framework of petroliferous rocks in Alaska, in Circum-Pacific energy and mineral resources: American Association of Petroleum Geologists Memoir 25, p. 291-307.

Grantz, Arthur, Wolf, S. C., Breslau, Lloyd, Johnson, T. C., and Hanna, W. F., 1970, Reconnaissance geology of the Chukchi Sea as determined by acoustic and magnetic profiling, in Adkison, W. L., and Brosgé, M. M., eds., Geological seminar on the North Slope of Alaska, Palo Alto, Calif., 1970: Los Angeles, Calif., American Association of Petroleum Geologists, Pacific Section Meeting, Proceedings, p. F1-F28.

Grybeck, Donald, Beikman, H. M., Borsgé, W. P., Tailleur, I. L., and Mul1, C. G., 1977, Geologic map of the Brooks Range, Alaska: U.S. Geological Survey Open-File Report 77166-B, 2 sheets, scale 1:1,000,000.

Gryc, George, and others, 1956, Mesozoic sequence in Colville River region, northern Alaska: American Association of Petroleum Geologists Bulletin, v. 40, p. 209-254.

Gryc, George, Patton, W. W., Jr., and Payne, T. G., 1951, Present Cretaceous stratigraphic 
nomenclature of northern Alaska: Washington Academy of Sciences Journal, v. 41, no. 5, p. 159-167.

Harwood, R. J., 1977, Oil and gas generation by laboratory pyrolysis of kerogen: American Association of Petroleum Geologists Bulletin, v. 61, p. 2082-2102.

Hickey, L. J., and Doyle, J. A., 1977, Early Cretaceous evidence for angiosperm evolution: Bot. Rev., v. 43, no. 1, p. 3104.

Hollick, Arthur, 1930, The Upper Cretaceous floras of Alaska: U.S. Geological Survey Professional Paper 159, 123 p.

Hood, A., Gutjahr, C. C. M., and Heacock, R. L., 1975, Organic metamorphism and the generation of petroleum: American Association of Petroleum Geologists Bulletin, v. 59, p. 986-996.

Hopkins, W. S., 1974, Some spores and pollen from the Christopher Formation (Albian) of Ellef and Amund Ringes Island, and northwestern Melville Island, Canadian Arctic Archipelago: Canadian Geological Survey Paper 74-30, 39 p.

Hopkins, W. S., Jr., and Balkwill, H. R., 1973, Description, palynology and paleoecology of the Hassel Formation (Cretaceous) on eastern Ellef Ringness Island, District of Franklin: Canadian Geological Survey Paper 72-37, 31 $\mathrm{p}$.

Hunter, R. E., and Fox, J. E., 1976, Interpretation of depositional environments in the Fortress Mountain Formation, central Arctic Slope, in Cobb, E. H., ed., The United States Geological Survey in Alaska-Accomplishments during 1975: U.S. Geological Survey Circular 733, p. 30-31.

Imlay, R. W., 1961, Characteristic lower Cretaceous megafossils of northern Alaska: U.S. Geological Survey Professional Paper 335, $74 \mathrm{p}$.

Jarzen D. M., and Norris, Geoffrey, 1975, Evolutionary significance and botanical relationships of Cretaceous angiosperm pollen of the western Canadian Interior: Geoscience and Man, v. 11, p. 47-60.

Jones, D. L., and Gryc, George, 1960, Upper Cretaceous pelecypods of the genus Inoceramus from northern Alaska: U.S. Geological Survey Professional Paper 334-E, p. 149-165.

Knowlton, F. H., 1914, The Jurassic flora of Cape Lisburne, Alaska: U.S. Geological Survey Professional Paper 85-D, p. 39-65.

Krumbein, W. C., 1941, Measurement and geological significance of shape and roundness of sedimentary particles: Journal of Sedimentary Petrology, v. 11, p. 64-72.

Krynine, P. D., 1947, Reservoir characteristics indicated by thin-section analyses of sand cores from Umiat Test Well No. 1: U.S. Geological Survey, Geological Investigations, Naval Petroleum Reserve No. 4 and adjacent areas, Alaska, Regular
Report 9, 11 p., 1 fig., 3 pls; released as an open-file report in 1954 .

1948 , Petrography and reservoir

characteristics of selected Tertiary and Cretaceous sandstone cores from Naval

Petroleum Reserve No. 4: U.S. Geological Survey, Geological Investigations, Naval Petroleum Reserve No. 4 and adjacent areas, Alaska, Regular Report 20, 47 p.; released as an open-file report in 1954.

Krynine, P. D., and Ferm, J. C., 1952, Petrography and reservoir characteristics of Umiat Test Well 9: U.S. Geological Survey, Geological Investigations, Naval Petroleum Reserve No. 4 and adjacent areas, Alaska, Special Report 34, 31 p., 13 figs.; released as an open-file report in 1954.

Langenheim, R. L., Smiley, C. J., and Gray, Jane, 1960, Cretaceous amber from the Arctic Coastal Plain of Alaska: Geological Society of America Bulletin, v. 71, p. 1345-1356.

Lathram, E. H., 1965, Preliminary geologic map of northern Alaska: U.S. Geological Survey Open-file report, scale $1: 1,000,000$.

Lebedev, E. L., 1974, Albian flora and stratigraphy of the Lower Cretaceous of west Priokhoti [in Russian]: Akademiya Nauk SSSR Doklady 254, 147 p.

Martin, A. J., 1970, Structure and tectonic history of the western Brooks Range, DeLong Mountains and Lisburne Hills, northern Alaska: Geological Society of America Bulletin, v. 81, p. 3605-3622.

Mayfield, C. F., Tailleur, I. L., Mull, C. G., and Sable, E. G., 1978, Bedrock geologic map of the south half of National Petroleum Reserve in Alaska: U.S. Geological Survey Open-File Report 78-70-B, 2 sheets.

Mellon, G. B., and Wall, J. H., 1956, Foraminifera of the upper McMurray and basal Clearwater Formations, pt. 1 of Geology of the McMurray Formation: Research Council of Alberta Report 72, P. 1-29.

Mia11, A. D., 1976, Facies models 4--Deltas: Geoscience Canada, v. 3, p. 215-227.

Mitchum, R. M., Jr., 1977, Seismic stratigraphy and global changes of sea level, Part II-Glossary of terms used in seismic stratigraphy, in Payton, C. E., ed., Seismic stratigraphy--Applications to hydrocarbon exploration: American Association of Petroleum Geologists Memoir 26, p. 205-212.

Mountjoy, E. W., and Chamney, T. P., 1969, Lower Cretaceous (Albian) of the Yukon-Stratigraphy and foraminiferal subdivisions, Sanke and Peel Rivers: Canada Geologicą1 Survey Paper 68-26, 71 p.

Mul1, C. G., 1977, Apparent south vergent folding and possible nappes in Schwatka Mountains, in Blean, K. M., ed., The 
United States Geological Survey in Alaska-Accomplishments during 1976: U.S. Geologica1 Survey Circular 751-B, p. B29B31.

Mul1, C. G., and Tailleur, I. L., 1977, Sadlerochit(?) Group in the Schwatka Mountains, south-central Brooks Range, in Blean, K. M., ed., The United States Geological Survey in Alaska-Accomplishments during 1976: U.S. Geological Survey Circular 751-B, p. B27B29.

Mul1, C. G., Tailleur, I. L., Mayfield, C. F., and Pessel, G. H., 1976, New structural and stratigraphic interpretations, central and western Brooks Range and Arctic Slope, in Cobb, E. H., ed., The United States Geological Survey in Alaska-Accomplishments during 1975: U.S. Geological Survey Circular 733, p. 24-26.

Newman, G. W., Mull, C. G., and Watkins, N. D., 1977, Northern Alaska paleomagnetism, plate rotation, and tectonics, in Alaska Geological Society Symposium, The relationship of plate tectonics to Alaskan geology and resources, April 4-6, 1977 [abs.]: Anchorage, Alaska Geological Society, p. 16-19.

Norris, Geoffrey, Jarzen, D. M., and AwaiThorne, B. V., 1975, Evolution of the Cretaceous terrestrial palynoflora in western Canada: Geological Association of Canada Special Paper 13, p. 333-364.

North Slope Stratigraphic Commission, 1971, West to east stratigraphic correlation section, Point Barrow to Ignek Valley, Arctic North Slope, Alaska: Anchorage, Alaska, Alaska Geological Society publication.

Patton, W. W. Jr., 1956, New and redefined formations of Early Cretaceous age, in Gryc, George, and others, Mesozoic sequence in Colville River region, northern Alaska: American Association of Petroleum Geologists Bulletin, v. 40, no. 2, p. 219223.

Patton, W. W., Jr., and Tailleur, I. L., 1964, Geology of the Killik-Itkillik region, Alaska: U.S. Geologica1 Survey Professional Paper 303-G, p. 409-500.

Payne, T. G., 1955, Mesozoic and Cenozoic tectonic elements of Alaska: U.S. Geological Survey Miscellaneous Geological Investigations Map I-84, scale 1:5,000,000.

Payne, T. G., and others, 1952, Geology of the Arctic slope of Alaska: U.S. Geological Survey Oil and Gas Investigations Map OM126,3 sheets.

Pessel, G. H., Garland, R. E., Tailleur, I. L., and Eakins, G. R., 1973, Preliminary geologic map of southeastern Ambler River and part of Survey Pass quadrangles, Alaska: Alaska Division of Geological and Geophysical Surveys Open-File Report 28 .

Pettijohn, F. J., Potter, P. E., and Siever,
R., 1972, Sand and sandstone: New York, Springer-Verlag, $618 \mathrm{p}$.

Retallack, G. J., 1977, Reconstructing Triassic vegetation of eastern Australasia--A new approach for the biostratigraphy of Gondwanaland: Alcheringia, v. 1, p. 247277.

Rich, J. L., 1951, Three critical environments of deposition and criteria for recognition of rocks deposited in each of them:

Geological Society of America Bulletin, v. 62 , p. 1-20.

Rickwood, F. K., 1970, The Prudhoe Bay field, in Geological seminar on the North Slope of Alaska, Palo Alto, Calif., 1970: Los Angeles, Calif., American Association of Petroleum Geologists, Pacific Section Meeting, Proceedings, p. L1-L11.

Robinson, F. M., 1956, Core tests and test wells, Oumalik area, Alaska, with Paleontology of test wells and core tests in the Oumalik area, Alaska, by H. R. Bergquist: U.S. Geological Survey Professional Paper 305-A, p. 1-70. 1958, Test wells, Gubik area, Alaska, with Micropaleontologic study of the Gubik test wells, northern Alaska, by H. R. Bergquist: U.S. Geological Survey Professional Paper 305-C, p. 207-264. 1959a, Test well, Grandstand area, Alaska, with Micropaleontologic study of Grandstand test well 1 , northern Alaska, by H. R. Bergquist: U.S. Geological Survey Professional Paper 305-E, p. 317-339. 1959b, Test wells, Titaluk and Knifeblade areas, Alaska, with Micropaleontologic study of test wells in the Titaluk and Knifeblade areas, northern Alaska, by $\mathrm{H}$. R. Bergquist: U.S. Geological Survey Professional Paper 305-G, p. 377-422. 1959c, Test wells, Simpson area, Alaska, with a section on Core analyses, by S. T. Yuster: U.S. Geological Survey Professional Paper 305-J, p. 523-568. 1964, Core tests, Simpson area, Alaska, with a section on Temperature measurement studies, by M. C. Brewer: U.S. Geological Survey Professional Paper 305-L, p. 654730.

[Professional Paper 305, issued only as separate chapters under the general title, Exploration of Naval Petroleum Reserve No. 4 and adjacent areas, northern Alaska, part 5, Subsurface geology and engineering data]

Roeder, Dietrich, and Mu11, C. G., 1978, Tectonics of Brooks Range ophiolites, Alaska: American Association of Petroleum Geologists Bulletin, v. 62, no. 9,

Samylina, V. A., 1963, The Mesozoic flora of the lower course of the Aldan River [in Russian]: Akademiya Nauk SSSR

Paleobotanica, ser. 8, v. 4, p. 58-139. 1964, The Mesozoic flora of the area west of the Kolyma River (Zyrianka coal basin); 
Part 1 [in Russian]: Akademiya Nauk SSSR Botanica Institut Trudy, ser. 8, v. 5, p. 39-79.

1976, The Cretaceous flora of Omsukshan (Magadan district) [in Russian]: Akademiya Nauk SSSR Komarov Botanica Institut Publication, $208 \mathrm{p}$.

Seely, D. R., Vail, P. R., and Walton, G. G., 1974, Trench slope model, in Burk, C. A., and Drake, C. L., eds., The geology of continental margins: New York, SpringerVerlag, Inc., p. 249-260.

Singh, C., 1971, Lower Cretaceous microfloras of the Peace River area, northwestern Alberta: Research Council of Alberta Bulletin 28, v. 2, 239 p., p1. 1-29.

1975, Stratigraphic significance of early angiosperm pollen in the Mid-Cretaceous strata of Alberta: Geological Association of Canada Special Paper 13, p. 365-389.

Sliter, W. V., in press, Albian foraminifers from the Christopher Formation of the Canadian Arctic Islands, in Palmer, A. R., and others, Contributions to Canadian paleontology: Canadian Geological Survey Bulletin 300.

Smiley, C. J., 1966, Cretaceous floras from Kuk River area, Alaska--Stratigraphic and climatic interpretations: Geological Society of America Bulletin, v. 77, no. 1, p. 1-14.

1967, Paleoclimatic interpretations of some Mesozoic floral sequences: American Association of Petroleum Geologists Bulletin, v. 51, p. 849-863.

1969a, Cretaceous floras of ChandlerColville region, Alaska--Stratigraphy and preliminary floristics: American Association of Petroleum Geologists Bulletin, v. 53, p. 482-502.

$1969 \mathrm{~b}$, Floral zones and correlations of Cretaceous Kukpowruk and Corwin Formations, northwestern Alaska: American Association of Petroleum Geologists Bulletin, v. 53, p. 2079-2093.

1972a, Applicability of plant megafossil biostratigraphy to marine-non-marine correlations-An example from the Cretaceous of northern Alaska: International Geology Congress Proceedings, 24th, sec. 7, p. 413421 .

1972b, Plant megafossil sequences, North Slope Cretaceous: Geoscience and Man, v. 4, p. 91-99.

Snelson, Sigmund, and Tailleur, I. L., 1968, Large scale thrusting and migrating Cretaceous foredeeps in western Brooks Range and adjacent regions of northwestern Alaska [abs.]: American Association of Petroleum Geologists Bulletin, v. 52, no. 3 , p. 567 .

Stanley, E. A., 1967, Cretaceous pollen and spore assemblages from northern Alaska: Review of Palaeobotany and Palynology, v. 1, p. 229-234.
Tailleur, I. L., 1973, Probable rift origin of the Canada basin, Arctic Ocean, in Pitcher, M. G., ed., Arctic Geology: American Association of Petroleum Geologists Memoir 19, p. 526-535; abstract appeared in 1970 in American Association of Petroleum Geologists Bulletin, v. 54, no. 12, p. 2508.

Tailleur, I. L., and Brosgé, W. P., 1970, Tectonic history of northern Alaska, in Adkison, W. L., and Brosgé, M. M., eds., Geological seminar on the North Slope of Alaska, Palo Alto, California, 1970: Los Angeles, Calif., American Association of Petroleum Geologists, Pacific Section Meeting, Proceedings, p. E1-E18.

Tailleur, I. L., Brosge, W. P., and Reiser, H. N., 1967, Palinspastic analysis of Devonian rocks in northwestern Alaska, in Oswald, D. H., ed., International symposium on the Devonian system, Calgary, 1967: Calgary, Alberta, Alberta Society of Petroleum Geologists, Proceedings, v. 1, p. 703-716; 1968 , v. 2, p. 1345-1361.

Tailleur, I. L., Kent, B. H., and Reiser, H. N., 1966, Outcrop geologic maps of the NukaEtivluk region, northern Alaska: U.S. Geological Survey Open-file report, 5 sheets, scale $1: 63,360$.

Tailleur, I. L., Mamel, B. L., and Dutro, J. T., Jr., 1973, Revised age and structural interpretation of Nuka Formation of Nuka Ridge, northwestern Alaska: American Association of Petroleum Geologists Bulletin, v. 57, p. 1348-1352.

Tailleur, I. L., and Sable, E. G., 1963, Nuka Formation of Late Mississippian to Late Permian age, new formation in northern Alaska: American Association of Petroleum Geologists Bulletin, v. 47, no. 4, p. 632642.

Tailleur, I. L., and Snelson, Sigmund, 1969, Large-scale thrusting in northwestern Alaska possibly related to rifting of the Arctic Ocean [abs.]: Geological Society of America Special Paper 121, p. 569.

Tappan, Helen, 1960, Cretaceous biostratigraphy of northern Alaska: American Association of Petroleum Geologists Bulletin, v. 44, no. 3, p. 273-297.

1962, Cretaceous foraminifera, Part 3 of Foraminifera from the Arctic slope of Alaska: U.S. Geological Survey Professional Paper 236-C, p. 91-203.

Taylor, J. M., 1950, Pore-space reduction in sandstones: American Association of Petroleum Geologists Bulletin, v. 34, p. 701-716.

Tschudy, B. D., 1969, Species of Aquilapollenites and Fibulapollis from two Upper Cretaceous localities in Alaska: U.S. Geological Survey Professional Paper 643-A, p. 1-15.

Turner, D. L., Forbes, R. B., and Mayfield, C. F., 1978, K-Ar geochronology of the Survey Pass, Ambler River and Eastern Baird 
Mountains quadrangles, southwestern Brooks Range, Alaska: U.S. Geological Survey Open-File Report 78-254, 41 p.

Vasilevskaya, N. D., and Pavlov, V. V., 1963, Stratigraphy and flora of Cretaceous deposits of the Lena-0leneksk district, Lensk coal basin, Nauchno-Issled [in Russian]: Institut Geologii Arktiki Trudy, v. 128, 96 p.

Ward, L. F., 1905, Status of the Mesozoic floras of the United States: U.S. Geological Survey Monograph 48, pts. 1 and $2,616 \mathrm{p}$.

Weimer, R. J., 1970, Rates of deltaic sedimentation and intrabasin deformation, Upper Cretaceous of Rocky Mountain region, in Morgan, J. P., and Shaver, R. H., eds., Deltaic sedimentation--Modern and ancient: Society of Economic Paleontologists and
Mineralogists Special Publication 15, p. 270-292.

Wiggins, V. D., 1973, Upper Triassic dinoflagellates from Arctic Alaska: Micropaleontology, v. 19, no. 1, p. 1-17, 5 pls.

1975, The dinoflagellate family Pareodiniaceae--A Discussion: Geoscience and Man, v. 11, p. 95-115, 5 pls.

Winkler, Gary, McLean, Hugh, and Plafker, George, 1976, Textural and mineralogical study of sandstones from the onshore Gulf of Alaska Tertiary Province, southern Alaska: U.S. Geological Survey Open-File Report 76-198, 48 p.

Young, F. G., 1975, Upper Cretaceous stratigraphy, Yukon coastal plain and northwestern Mackenzie delta: Geological Survey of Canada Bulletin 249, 83 p. 
